$$
\begin{gathered}
\text { UNIVERSIDADE DE SÃO PAULO } \\
\text { FFCLRP- DEPARTAMENTO DE PSICOLOGIA } \\
\text { PROGRAMA DE PÓS-GRADUAÇÃO EM PSICOLOGIA }
\end{gathered}
$$

\title{
Vivências de profissionais de saúde na assistência a crianças e adolescentes com câncer: um estudo fenomenológico
}

\author{
Roberta Cancella Pinheiro Alves
}

Dissertação apresentada à Faculdade de Filosofia, Ciências e Letras de Ribeirão Preto da USP, como parte das exigências para obtenção do título de Mestre em Ciências, Área: Psicologia. 



\section{Vivências de profissionais de saúde na assistência a crianças e adolescentes com câncer: um estudo fenomenológico}

Dissertação apresentada à Faculdade de Filosofia, Ciências e Letras de Ribeirão Preto da USP, como parte das exigências para obtenção do título de Mestre em Ciências, Área: Psicologia.

Orientadora: Prof ${ }^{\mathrm{a}}$. Dr ${ }^{\mathrm{a}}$. Elizabeth Ranier Martins do Valle 


\section{AUTORIZO A REPRODUÇÃO E DIVULGAÇÃO TOTAL OU PARCIAL DESTE TRABALHO, POR QUALQUER MEIO CONVENCIONAL OU ELETRÔNICO, PARA FINS DE ESTUDO E PESQUISA, DESDE QUE CITADA A FONTE.}

\section{FICHA CATALOGRÁFICA}

Alves, Roberta Cancella Pinheiro

Vivências de profissionais de saúde na assistência a crianças e adolescentes com câncer: um estudo fenomenológico. Ribeirão Preto, 2012.

207 p.

Dissertação de Mestrado apresentada à Faculdade de Filosofia, Ciências e Letras de Ribeirão Preto/USP. Área de Concentração: Psicologia.

Orientadora: Valle, Elizabeth Ranier Martins do

1. Psico-Oncologia Pediátrica; 2. Fenomenologia; 3. Criança; 4. Adolescente; 5. Profissional de saúde. 
Nome: ALVES, Roberta Cancella Pinheiro

Título: Vivências de profissionais de saúde na assistência a crianças e adolescentes com câncer: um estudo fenomenológico.

Dissertação apresentada à Faculdade de Filosofia, Ciências e Letras de Ribeirão Preto da Universidade de São Paulo para obtenção do título de Mestre em Psicologia.

Aprovado em:

\section{Banca Examinadora}

Prof. Dr.

Instituição Assinatura:

Prof. Dr.

Instituição Assinatura:

Prof. Dr.

Instituição Assinatura: 

Este trabalho foi subvencionado pelo Conselho Nacional de Desenvolvimento Científico e Tecnológico - CNPq, mediante concessão de bolsa de Mestrado, no período de outubro de 2010 a setembro de 2012. 



\section{Dedicatória}

Aos profissionais de saúde, colaboradores deste estudo, que dividiram comigo as histórias, as alegrias e as dores da arte de cuidar de crianças e adolescentes com câncer, a minha profunda gratidão e admiração. 



\section{AGRADECIMENTOS}

Especialmente a Deus, Aquele que me ajuda a abrir os olhos para cada presente que Ele me oferece e que cabe a mim reconhecer e desembrulhar. Aquele que me ajuda a continuar e acreditar, mesmo quando a vida parece sair dos trilhos...

À querida Beth, pela oportunidade de ser por ela orientada, por toda a sua disponibilidade e disposição em contribuir com o meu desenvolvimento pessoal e profissional, por me aproximar ainda mais da Fenomenologia e por me permitir desenvolver esse trabalho levando em consideração toda a minha subjetividade.

Às professoras Magali Roseira Boemer e Carmen Lúcia Cardoso, pelas valiosas contribuições proporcionadas no Exame de Qualificação, que me ajudaram a enriquecer este trabalho.

À professora Érika Arantes de Oliveira-Cardoso, minha orientadora no período de Iniciação Científica e ao professor Manoel Antônio dos Santos que contribuíram para que eu me encantasse com esse "mundo das pesquisas", por tudo o que me ensinaram e que se tornou a base do meu conhecimento em pesquisa em Psicologia.

À professora Leandra Rossi, por ter me aberto as portas do estágio em PsicoOncologia Pediátrica, quando eu ainda era uma aluna de Psicologia, proporcionando contribuições únicas e decisivas à minha formação profissional. Agradeço também as sugestões ao longo da realização deste estudo.

Aos profissionais da Biblioteca Central de Ribeirão Preto da Universidade de São Paulo pela disponibilidade e dedicação na revisão deste trabalho.

Aos meus amados pais, por tudo que fizeram e continuam fazendo por minha formação pessoal e profissional, por sonharem comigo e me ajudarem a realizar este sonho. Por serem meus mestres desde sempre, me transmitindo conhecimentos e valores. Gratidão e admiração eternas!

Ao Gustavo, pelo apoio, incentivo e participação em vários momentos dessa trajetória.

Ao Ricardinho, pelo exemplo de dedicação, persistência e serenidade.

Ao Belo, por me encantar e contagiar com sua maneira leve de existir.

A todas as minhas queridas amigas, que me ajudaram a acreditar que esse caminho seria possível de ser trilhado a despeito dos obstáculos.

Aos meus alunos, que me possibilitam um aprendizado constante e que me estimulam a aprimorar meus conhecimentos a cada dia. 
Ao Conselho Nacional de Desenvolvimento Científico e Tecnológico - CNPq - pelo apoio financeiro para desenvolvimento deste trabalho.

Aos profissionais de saúde, colaboradores deste estudo, agradeço a generosidade com que se dispuseram a participar e a oportunidade de compartilhar histórias tão ricas. Agradeço a confiança e a permissão para me aproximar de suas experiências. 


\section{RESUMO}

ALVES, R. C. P. Vivências de profissionais de saúde na assistência a crianças e adolescentes com câncer: um estudo fenomenológico. 2012. 207 f. Dissertação (Mestrado) - Faculdade de Filosofia, Ciências e Letras de Ribeirão Preto, Universidade de São Paulo, Ribeirão Preto, 2012.

O câncer corresponde a um grupo de doenças que têm em comum o poder de proliferar células anormais de natureza embrionária primitiva em qualquer parte do organismo. A despeito dos avanços científicos e tecnológicos que permitem um aumento nas possibilidades de cura, o câncer desencadeia repercussões psicológicas em pacientes e familiares. Neste cenário de adoecimento torna-se essencial que esses indivíduos possam ser assistidos por profissionais de saúde que os orientem e os acolham em suas necessidades específicas. Porém, a atuação permeada pelo contato com profissionais de diferentes áreas, por jornadas prolongadas de trabalho e pelo convívio frequente com imprevisibilidade, vulnerabilidade, sofrimento e perda de pacientes, pode gerar sofrimento aos profissionais, dificultando uma assistência de qualidade aos pacientes. Esse estudo teve como objetivo compreender como profissionais de saúde, de diferentes especialidades, atuantes em um serviço especializado em tratamento oncológico pediátrico, vinculado a um hospital-escola do interior do estado de São Paulo, significam suas vivências neste contexto de trabalho. Foram entrevistados oito profissionais e, mediante autorização prévia dos mesmos, as entrevistas foram gravadas e transcritas na íntegra. A compreensão dos relatos foi realizada segundo o referencial fenomenológico, que se justifica pela necessidade de chegar à experiência tal como é vivida e de aproximar dos sentidos atribuídos pelos participantes. As entrevistas foram analisadas qualitativamente conforme o método de análise da estrutura do fenômeno situado, proposto por Martins e Bicudo (1989), Giorgi (1985) e Valle (1997) e, posteriormente, foi realizada uma reflexão sobre os resultados à luz da Psicologia Fenomenológica proposta por Forghieri (2009). Os resultados mostraram que os participantes vivenciam sua atuação de forma ambivalente, marcada por satisfações e dificuldades. A satisfação aparece associada ao vínculo construído e às lições aprendidas com pacientes e familiares, ao reconhecimento recebido pelo trabalho prestado e à oportunidade de servir ao próximo. As dificuldades estão relacionadas ao contato com o sofrimento e com a morte de pacientes, ao convívio com profissionais de diferentes especialidades e à dificuldade de comunicação entre eles, essas últimas representando obstáculos a uma atuação integrada. Apesar das dificuldades, eles revelam disponibilidade e desejo de cuidar de seus pacientes, o que faz com que continuem escolhendo esse trabalho. Com intuito de lidar melhor com esse cenário, mobilizam diferentes recursos de enfrentamento, porém, ainda assim, em vários momentos, sentem-se desamparados tanto pelos colegas como pela instituição hospitalar e pela formação acadêmica. Frente aos desafios da prática, esse estudo ressalta a importância de repensar a formação em saúde, bem como a necessidade de oferta de assistência psicológica aos profissionais, como uma estratégia de cuidado ao cuidador. Destinar atenção à saúde mental dos profissionais de saúde é essencial para que eles tenham condições para adotar condutas mais humanizadas, proporcionando uma melhor qualidade da assistência aos pacientes.

Palavras-chave: Psico-Oncologia Pediátrica; Fenomenologia; Criança; Adolescente; Profissional de saúde. 



\begin{abstract}
ALVES, R. C. P. Health professionals experiences in assisting children and adolescents who have cancer: a phenomenological study. 2012. 207 pp. Dissertation (MA) - Faculdade de Filosofia, Ciências e Letras de Ribeirão Preto, Universidade de São Paulo, Ribeirão Preto, 2012.
\end{abstract}

Cancer corresponds to a group of diseases that have in commom the power to proliferate abnormal cells of a primitive embrio origin in any part of the organism. Despite the scientific advances which allow a raise in the chances of cure, cancer triggers psychological repercussions in patients and their families. In this scenario of illness it is tantamount that these individuals may be assisted by health professionals who guide them and cater for their specific needs. However, the acting permeated by the contact with professionals from various areas, by long working hours and by the constant idea of unpredictability, vulnerability, suffering and loss of patients might generate anguish to these professionals, making it difficult to have high quality assistance towards these patients. This study aimed at understanding how health professionals, of different areas of expertise, actively working in a job which is specific to the pediatrics oncologic treatment, linked to a university hospital in the inner area of the state of São Paulo, see the experiences they have within the scope of their work. Eight professionals were interviewed and, having the subjects previously authorized, the interviews were recorded and transcribed word by word. The comprehension of the reports was performed according to the phenomenological reference, which is justified by the need to reach the experience exactly the same way it is lived and to get closer to the senses assigned by the participants. The interviews were qualitatively analysed in accordance with the method of situated phenomenon structure analysis, proposed by Martins and Bicudo (1989), Giorgi (1985) and Valle (1997) and, later, a reflexion upon the results was carried out in light of the Phenomenological Psychology proposed by Forghieri (2009). The results showed that the participants live their acting in an ambivalent way, marked by pleasures and difficulties. The pleasures are associated with the bonding built and with the lessons learned with patients and their families, with the recognition awarded by the done service and the opportunity of helping a peer. The difficulties are related to the contact with suffering and to the death of the patients, to the living with professionals of different specialities and to the difficult communication among them, the latest representing obstacles to an integrated acting. In spite of the difficulties, they reveal availability and good will to handle the patients, which makes them keep choosing this line of work. Aiming at dealing better with this scenario, they mobilize different resources of confrontation, yet, still in numerous moments, they feel unassisted both by their co-workers and the hospital institution, as well as by the academic course. Facing the practice challenges, this paper highlights the importance of rethinking the graduation in the area of health, and also the need of offering psychological aid to the professionals as a strategy of care towards the caretaker. Paying attention to the mental health of the health professionals is essential so that they are in good shape to adopt more humanistic approaches, offering assistance of a higher quality towards these patients.

Key words: Psycho-Oncology Pediatrics; Phenomenology; Child; Adolescent; Health professional. 



\section{SUMÁRIO}

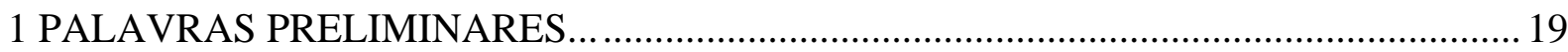

2 JUSTIFICATIVA PARA REALIZAÇÃO DO ESTUDO ........................................21

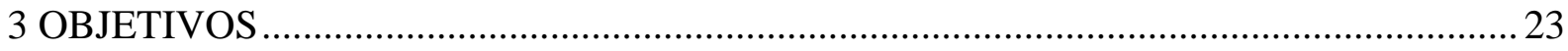

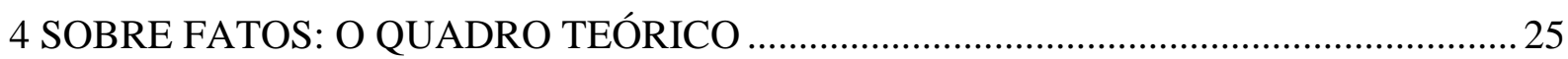

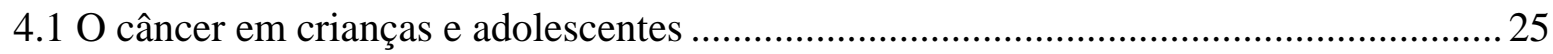

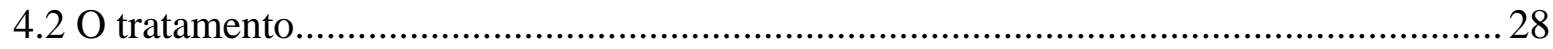

4.3 Repercussões psicológicas do adoecer em pacientes e familiares ................................. 29

4.4 A prática de saúde: a predominância do modelo biomédico .......................................... 32

4.5 Uma proposta de atuação em saúde: O modelo biopsicossocial e a

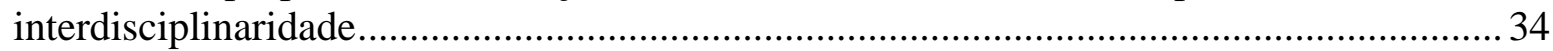

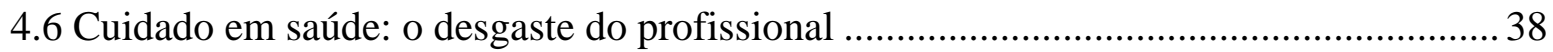

5 A TRAJETÓRIA METODOLÓGICA: UM CAMINHO PARA A COMPREENSÃO

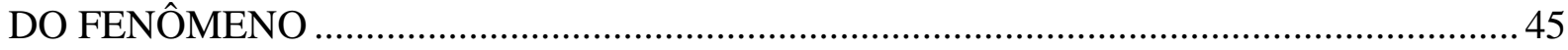

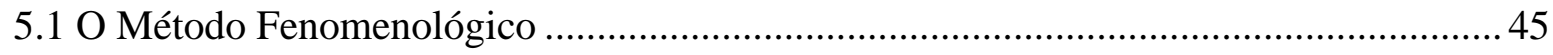

5.2 O Enfoque Fenomenológico da Personalidade ............................................................... 54

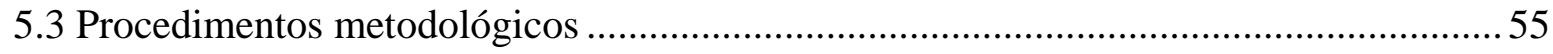

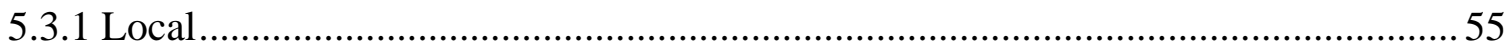

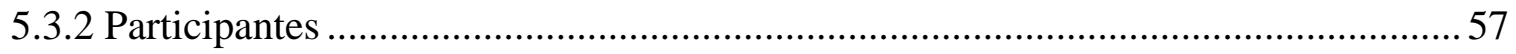

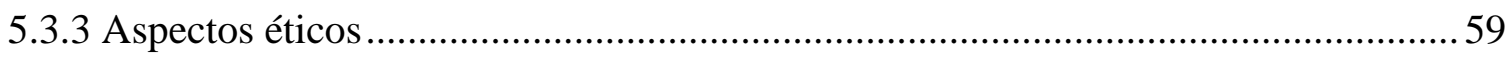

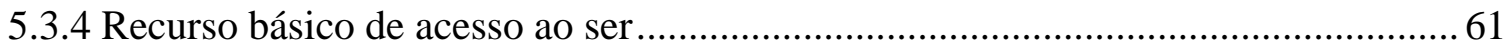

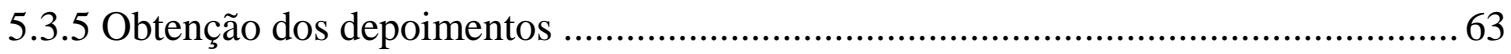

5.3.6 Proposta de Análise Fenomenológica dos Depoimentos: "Modalidade do

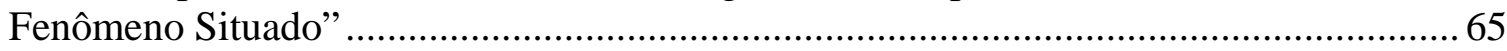

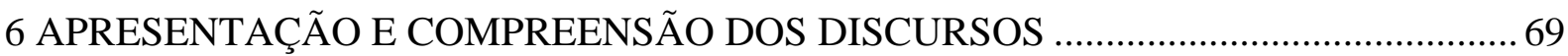

6.1 Adentrando em um contexto de atuação peculiar: especificidades do cuidado em

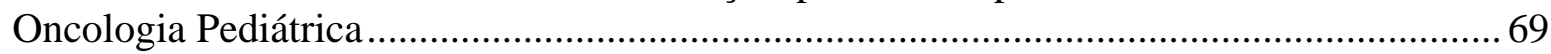

6. 2 A essência do cuidar em Oncologia Pediátrica: significados ...................................... 76

6.2.1 Acolhimento, escuta e acompanhamento ............................................................. 78

6.2.2 Atenção às necessidades singulares de pacientes e seus familiares ......................... 80

6.2.3 Envolvimento, empatia e manifestação de sentimentos permeando o cuidado ........ 82

6.2.4 Respeitar, solucionar dúvidas e fornecer informações............................................. 85

6.2.5 Um cuidado que transcende o momento presente e que atente aos aspectos psicológicos e sociais envolvidos no processo de adoecimento ....................................... 87

6.2.6 Facilitar a comunicação e a responsabilização pelo próprio existir .......................... 89 
6.2.7 Cuidado aos pacientes terminais e aos familiares enlutados

6.3. Tocar o outro e ser tocado por ele: uma relação de cuidado permeada por desafios e realizações

6.4 Atuação em equipe: importância e desafios 107

6.5 Cuidando de quem cuida: estratégias para lidar com a dor do ofício

6.5.1 Limite de envolvimento, separação entre aspectos pessoais e profissionais e

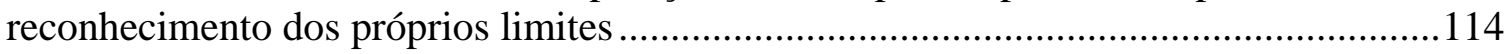

6.5.2 Experiência profissional e atenção aos próprios aspectos emocionais

6.5.3 Compartilhar dificuldades, dividir as dores, ter colegas de trabalho como

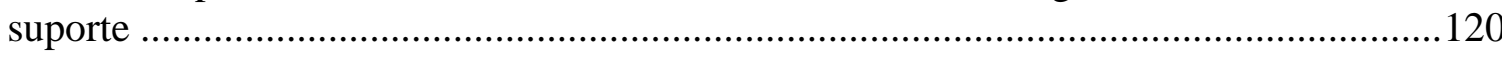

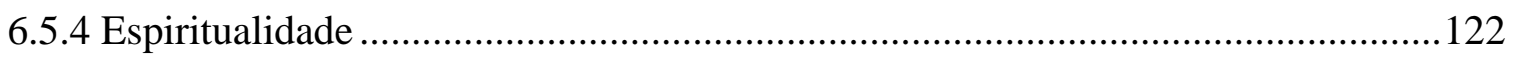

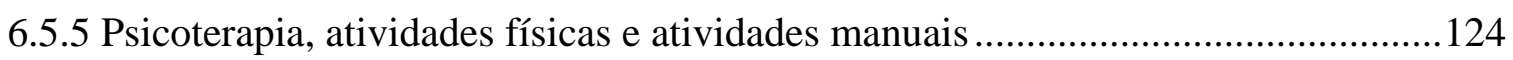

6.5.6 Outros recursos: sentimento de dever cumprido; sentimento de capacitação; racionalização; bom humor.......................................................................................... 124

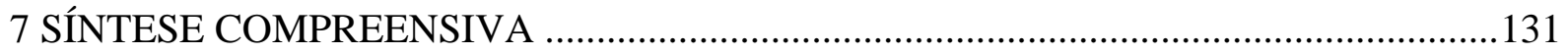

8 REFLEXÕES SOBRE O EXISTIR DOS PROFISSIONAIS DE SAÚDE À LUZ DA

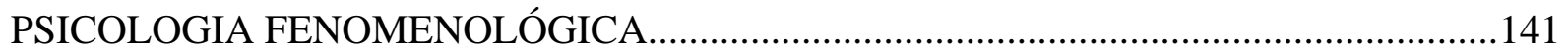

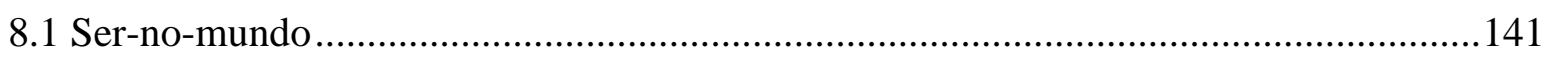

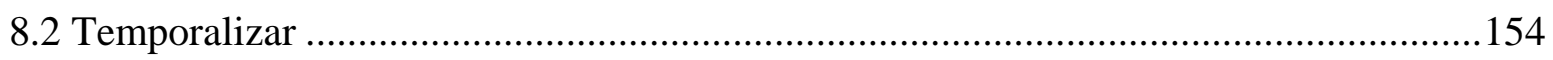

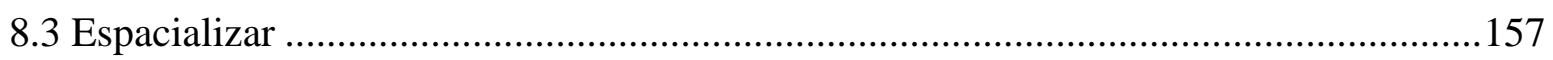

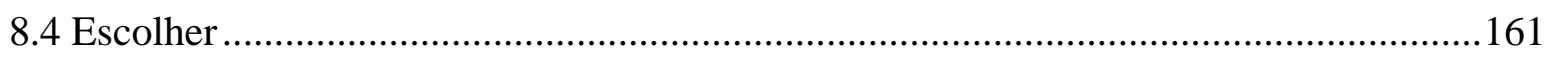

8.5 Ser-saudável e Ser-doente Existencialmente...........................................................166

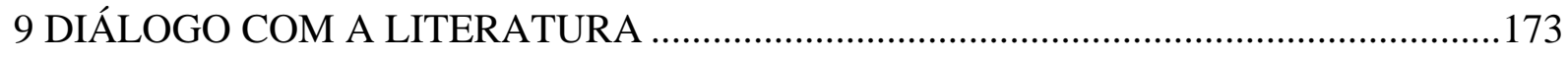

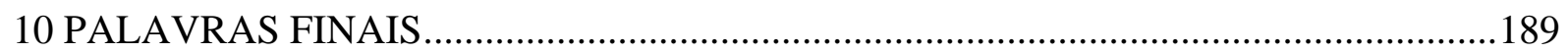

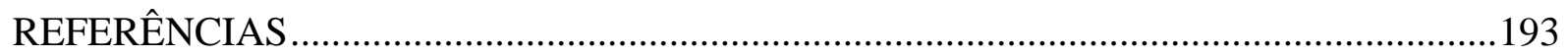

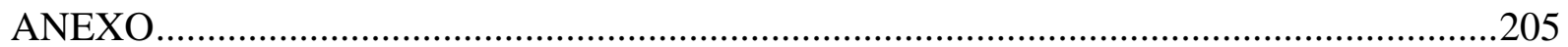

ANEXO A - Autorização do Comitê de Ética em Pesquisa do HCFMRP-USP para

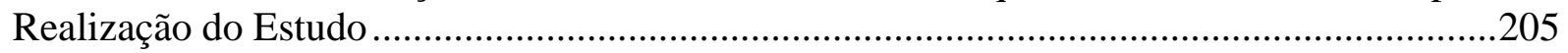

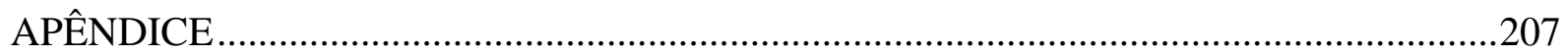

APÊNDICE A - Termo de Consentimento Livre e Informado .............................................207 


\section{Palavras Preliminares... 1}

Inicialmente, acredito ser importante resgatar meu percurso dentro do curso de Psicologia, incluindo minha aproximação à área de saúde, à Oncologia e à Fenomenologia, pelo fato de este estudo buscar compreender a atuação de profissionais de saúde junto a crianças e adolescentes com câncer, através de um olhar fenomenológico.

Durante a graduação em Psicologia pela Faculdade de Filosofia, Ciências e Letras de Ribeirão Preto - USP, minhas escolhas convergiram para o estudo e a prática da Psicologia em um contexto de saúde.

No início do $2^{\circ}$ ano da graduação, ingressei como participante de um grupo voltado para discussões teóricas referentes ao adoecimento de pessoas com câncer e à realização de Transplante de Medula Óssea como possibilidade terapêutica. Percebi que, apesar de se tratar de uma temática difícil, por ser mobilizadora e por fazer com que eu entrasse em contato com a dor, com a vulnerabilidade humana, com a finitude da existência e com a lembrança de uma pessoa querida que passou por um câncer incurável, tinha ali algo que me encantava e, ao mesmo tempo, me desafiava. Senti-me, então, motivada a escrever um projeto que culminou no meu trabalho de Iniciação Científica, intitulado “Qualidade de vida de pacientes submetidos ao transplante de medula óssea após alta hospitalar” ${ }^{2}$, sob orientação da psicóloga $\operatorname{Prof}^{\mathrm{a}} \mathrm{Dr}^{\mathrm{a}}$. Érika Arantes de Oliveira-Cardoso e desenvolvido com apoio da Fundação de Amparo à Pesquisa do Estado de São Paulo (FAPESP).

A Iniciação Científica foi uma oportunidade para me aproximar do "mundo das pesquisas”, de conhecer o universo do adoecimento por patologias graves e as repercussões psicológicas destas na vida de pacientes e suas famílias, além de uma chance de experimentar a escuta de pacientes que passaram por um momento difícil de adoecimento e que estavam tentando resgatar o sentido de viver, após a ameaça concreta de morte.

Ao longo do curso, iniciei também minhas aproximações com a abordagem Fenomenológico-Existencial e senti que havia ali algo que se encaixava à minha maneira de olhar o mundo e de ver o homem enquanto um vir-a-ser, que se constitui nas suas relações com os outros e com o mundo e que atribui sentidos singulares a cada uma de suas vivências.

\footnotetext{
${ }^{1}$ Esta dissertação foi revisada seguindo a Nova Ortografia da Língua Portuguesa, em vigor a partir de $1^{0}$ de janeiro de 2009, no Brasil.

${ }^{2}$ Alves, R.C.P. (2008). Qualidade de vida de pacientes submetidos ao Transplante de Medula Óssea após alta hospitalar. Monografia de Conclusão do Programa de Bacharelado em Pesquisa do Departamento de Psicologia e Educação da Faculdade de Filosofia, Ciências e Letras de Ribeirão Preto, Universidade de São Paulo, Ribeirão Preto (Orientadora: $\operatorname{Prof}^{\mathrm{a}}{ }^{\mathrm{D}} \mathrm{Dr}^{\mathrm{a}}$ Érika Arantes de Oliveira-Cardoso). FAPESP.
} 
Tive a oportunidade de assistir a palestras ministradas por profissionais que trabalham com a abordagem e de me aproximar de psicólogos que utilizavam a FenomenologiaExistencial em suas atuações junto a serviços de saúde.

Além disso, me envolvi com um grupo de estudos em Fenomenologia, visando uma maior aproximação com essa abordagem, já que sentia que havia uma lacuna teórica a ser preenchida devido à pouca oferta de disciplinas e estágios dentro desse referencial na instituição em que me graduei.

Paralelamente, tive a oportunidade de estagiar no Grupo de Apoio à Criança com Câncer (GACC) ${ }^{3}$ - junto ao Hospital das Clínicas da Faculdade de Medicina de Ribeirão Preto da Universidade de São Paulo (HCFMRP- USP). Esse estágio me permitiu conhecer a atuação do psicólogo hospitalar a partir da abordagem Fenomenológico-Existencial e a entrar em contato com crianças e adolescentes com câncer, seus familiares e com a equipe de saúde responsável pelo atendimento aos pacientes, bem como me aproximar de pesquisas utilizando o método fenomenológico na área da Psico-Oncologia Pediátrica.

Foi no estágio junto ao GACC que tive a oportunidade de conhecer a Prof ${ }^{\mathrm{a}}$. Dr ${ }^{\mathrm{a}}$. Elizabeth Ranier Martins do Valle, orientadora deste trabalho e supervisora orgânica do estágio.

Recém-formada, tive a oportunidade de continuar no Serviço de Psicologia no setor de Oncologia Pediátrica do Hospital das Clínicas como psicóloga voluntária através de um programa de aperfeiçoamento profissional. E, foi ao longo deste ano, precisamente 2009, que senti um misto de desejo, inquietação e necessidade de conhecer um pouco mais sobre PsicoOncologia Pediátrica não apenas na teoria e prática, mas, também, no campo de pesquisa.

Assim, em 2010, após contatos com minha atual orientadora, que demonstrou interesse, acolhimento e disponibilidade em me orientar, teve início este trabalho de mestrado!

\footnotetext{
3 Entidade beneficente, sem fins lucrativos, constituída por profissionais do Hospital das Clínicas da Faculdade de Medicina de Ribeirão (HCFMRP-USP) e da Escola de Enfermagem de Ribeirão Preto (EERP-USP) que, juntamente com voluntários e familiares de pacientes com câncer, desenvolvem atividades técnico-científicas e assistenciais visando a auxiliar crianças, adolescentes e seus familiares no enfrentamento do processo de adoecimento e tratamento.
} 


\section{JUSTIFICATIVA PARA REALIZAÇÃO DO ESTUdo}

A proposta de investigação surgiu a partir da minha própria inquietação com relação a como profissionais, integrantes de uma equipe de saúde voltada para a atenção a crianças e adolescentes com câncer, vivenciam a sua própria atuação e emergiu, também, do meu contato com esses profissionais por dois anos junto ao Serviço de Oncologia Pediátrica do HCFMRP-USP.

Nas minhas vivências no Serviço de Oncologia Pediátrica do HCFMRP-USP durante os anos de 2008 e 2009, pude perceber o quanto algumas temáticas motivavam discussões na equipe de saúde e mobilizavam alguns profissionais, entre elas: limites pessoais e profissionais, dificuldades para lidar com pacientes questionadores, comunicações de diagnósticos e de recidivas de câncer e a atuação junto a pacientes terminais e a seus familiares. Esses debates me inquietaram e foram vistos por mim como um desejo desses profissionais de saber manejar melhor situações difíceis, de trocar informações e buscar apoio em outros membros da mesma equipe.

Passei a questionar-me como é para esses profissionais trabalharem com essa clientela, como lidam com a dor, com a perda de pacientes, com a longa jornada de trabalho... Como é relacionar-se com esses pacientes e com seus familiares? E como isso é visto pelos próprios profissionais? Como enfrentam dificuldades no âmbito profissional? E a atenção ao próprio profissional?

De acordo com Fini (1994), a pesquisa de inspiração fenomenológica surge com uma interrogação do pesquisador, que emerge de sua insatisfação em relação àquilo que ele acredita saber sobre algo. O fenômeno faz parte do "mundo vida” do pesquisador, sendo-lhe familiar; apesar disso, causa-lhe estranhamento, inquietação, tensão, o que impulsiona o movimento intuitivo do pesquisador em busca da essência do fenômeno que interroga.

Destinar atenção para a realidade dos serviços de saúde e para a atuação dos profissionais é importante uma vez que pode propiciar o desenvolvimento de estratégias para cuidar de quem cuida, para que esses profissionais da saúde possam ter recursos para adotar condutas mais humanizadas e para melhorar a qualidade da assistência. Além disso, conhecer as vivências desses profissionais é essencial para refletir sobre a formação profissional dos mesmos.

Segundo Turato (2005), conhecer os significados dos fenômenos ligados ao processo de saúde-doença possibilita uma melhor qualidade da relação profissional-paciente-família- 
instituição, maior adesão dos pacientes aos tratamentos, maior compreensão de sentimentos, ideias e comportamentos de profissionais, pacientes e familiares.

Para buscar respostas para minha inquietação percorri a seguinte trajetória: após participar da seleção para Pós-Graduação em nível de Mestrado da Faculdade de Filosofia, Ciências e Letras de Ribeirão Preto da Universidade de São Paulo (FFCLRP-USP) e o projeto de pesquisa ter sido aprovado pelo Programa de Pós-Graduação desta faculdade e pelo Comitê de Ética do Hospital das Clínicas da Faculdade de Medicina de Ribeirão Preto (HCFMRPUSP), realizei um levantamento dos trabalhos relacionados à temática que pretendia estudar, visando a uma aproximação e a um contato com as publicações na área. Assim, pude ter um contato maior com estudos ligados ao câncer, à Oncologia infantil, às repercussões do adoecimento em crianças, adolescentes e familiares, à atuação dos profissionais de saúde e aos obstáculos à assistência interdisciplinar. Além disso, foram realizadas leituras visando a uma maior aproximação com o método fenomenológico e com a forma de conduzir entrevistas segundo essa metodologia. Após reuniões com minha orientadora, entrei em contato com profissionais de saúde, membros do serviço de Oncologia Pediátrica do HCFMRP-USP, para dar início à coleta de dados. Conforme as entrevistas foram sendo realizadas e transcritas, empreendi uma aproximação às mesmas de forma a compreendê-las. Depois de finalizar a etapa de compreensão de todas as entrevistas realizadas, busquei construir uma síntese compreensiva dos discursos dos participantes, para então realizar uma reflexão fenomenológica dessas entrevistas. Por fim, aproximei, através da literatura, de aspectos encontrados nos relatos dos participantes, que me chamaram maior atenção, para então, encerrar a redação deste estudo. 


\section{OBJETIVOS}

O objetivo deste estudo é possibilitar reflexões referentes a como tem sido para os profissionais de saúde lidarem com o câncer infanto-juvenil, com a dor, o sofrimento e, não raras vezes, com a perda de pacientes; além de buscar compreender os recursos de enfrentamento utilizados por eles para trabalharem neste contexto.

Com esse estudo, busco as diferentes possibilidades de vivenciar o ser-no-mundo de profissionais de saúde que atuam no contexto de Oncologia Pediátrica, esperando ser esta uma contribuição concreta para a Psicologia, bem como para áreas afins que possam se beneficiar deste trabalho.

Com o intuito de buscar compreender como os profissionais significam suas vivências, fundamentarei este estudo na metodologia de investigação fenomenológica. Esta proposta de investigação justifica-se pela necessidade de, como pesquisadora, chegar à experiência tal como é vivida e de aproximar-me dos significados e sentidos atribuídos pelos membros de um serviço de Oncologia Pediátrica que convivem com o exercício da assistência em saúde em situações em que o tratamento é longo e doloroso. Além disso, como foi dito anteriormente, a escolha pela Fenomenologia também vem ao encontro de minha visão de homem e de mundo. 


\section{SOBRE FATOS: O QUADRO TEÓRICO}

\subsection{O CÂNCER EM CRIANÇAS E ADOLESCENTES}

O câncer designa um grupo de várias doenças que têm como ponto central a proliferação em qualquer parte do organismo, de células anormais de natureza embrionária primitiva (HOSPITAL DO CÂNCER, 2003).

Envolve mais de uma centena de doenças, com causas múltiplas, histórias distintas e diferentes formas de tratamento. Os diferentes tipos de câncer correspondem aos vários tipos de células do corpo, afetando tecidos e órgãos. Sua manifestação mais comum é no sangue (leucemias), seguida de acometimento dos vasos linfáticos (linfomas) ou, ainda, os chamados tumores sólidos que atingem ossos, músculos, órgãos abdominais e sistema nervoso central (HOSPITAL DO CÂNCER, 2003; BRASIL, 2011).

As células cancerosas adquirem o poder de se desprender do tumor e migrar, invadindo tecidos vizinhos, podendo chegar ao interior de um vaso sanguíneo ou linfático e, através desses, disseminar-se, originando as metástases. Conforme as células cancerosas vão substituindo as normais, os tecidos invadidos vão perdendo suas funções gerando, por exemplo, alterações respiratórias e da consciência, dores de cabeça, entre outras, dependendo do tecido invadido (BRASIL, 1997).

As causas de câncer são variadas, podendo ser externas ou internas ao organismo, estando ambas inter-relacionadas. As causas externas relacionam-se ao meio ambiente e aos hábitos próprios de um ambiente social e cultural, enquanto que as causas internas são, na maioria das vezes, geneticamente pré-determinadas (BRANDÃO et al., 2004).

Nas últimas décadas, o câncer converteu-se em um problema de saúde pública mundial. A Organização Mundial da Saúde (OMS) estima que, no ano 2030, podem-se esperar 27 milhões de casos incidentes de câncer, 17 milhões de mortes por câncer e 75 milhões de pessoas vivas, anualmente, com câncer (BRASIL, 2011).

Seguindo tendência mundial, nota-se que, também no Brasil, tem havido mudanças no perfil das enfermidades que acometem a população. A partir dos anos 1960, as doenças infecciosas e parasitárias deixaram de ser a principal causa de morte, sendo substituídas pelas doenças do aparelho circulatório e pelas neoplasias. Esse aumento da incidência e da mortalidade por doenças crônico-degenerativas tem como principal fator o envelhecimento da 
população, resultante do intenso processo de urbanização e das ações de promoção e recuperação da saúde (BRASIL, 2011).

O contínuo crescimento populacional, bem como seu envelhecimento, afetará, significativamente, o impacto do câncer no mundo (BRASIL, 2009).

No Brasil, as estimativas para o ano de 2012, que serão válidas também para o ano de 2013, apontam a ocorrência de aproximadamente 518.510 casos novos de câncer na população, incluindo os casos de pele não melanoma. Excluindo os casos de câncer da pele não melanoma, estima-se um total de 385 mil casos novos (BRASIL, 2011).

Com relação ao câncer infanto-juvenil, depreende-se que ocorrerão cerca de 11.530 casos novos de câncer em crianças e adolescentes com idade até os dezenove anos (BRASIL, 2011).

No ano de 2009, os óbitos por neoplasias para a faixa etária de um a dezenove anos, encontraram-se entre as dez primeiras causas de morte no Brasil. A partir dos cinco anos, a morte por câncer corresponde à primeira causa de morte por doença em meninos e meninas (BRASIL, 2011).

É importante destacar que o câncer infanto-juvenil deve ser estudado separadamente do câncer do adulto, por apresentar diferenças em relação aos locais primários, às origens histológicas e ao comportamento clínico. Os tumores infanto-juvenis crescem rapidamente e são mais invasivos, porém respondem melhor ao tratamento e são considerados de bom prognóstico nessa faixa etária (BRASIL, 2011).

Diferentemente do câncer de adulto, o câncer infantil, geralmente, afeta as células do sistema sanguíneo e os tecidos de sustentação, enquanto que o câncer que acomete adultos afeta as células do epitélio, que recobre os diferentes órgãos - por exemplo, câncer de mama e câncer de pulmão. As doenças malignas da infância, por serem predominantemente de natureza embrionária, são constituídas de células indiferenciadas, o que determina, em geral, uma melhor resposta aos métodos terapêuticos (BRASIL, 2011).

No adulto, em muitas situações, o surgimento do câncer está associado claramente a fatores ambientais como, por exemplo, câncer de pulmão relacionado ao fumo. Nos tumores infanto-juvenis, até o momento, não existem evidências científicas que permitam observar claramente essa associação. Pouco se conhece sobre a etiologia do câncer na infância, principalmente por sua raridade, o que limita o poder estatístico de alguns estudos. Devido a seu curto período de latência, as exposições durante a vida intrauterina são o fator de risco mais conhecido na etiologia desse grupo de neoplasias (BRASIL, 2011; BRASIL, 2012). 
Com o progresso no desenvolvimento do tratamento do câncer na infância nas últimas quatro décadas, estima-se que em torno de 70\% das crianças acometidas de câncer possam ser curadas, desde que sejam diagnosticadas precocemente e tratadas em centros especializados. Acredita-se que, assim, a maioria dessas crianças terá boa qualidade de vida após o tratamento adequado (BRASIL, 2011).

Logo, a importância de uma detecção precoce está ligada à sua interferência nas chances de sobrevida dos pacientes. A desinformação dos pais e médicos, o medo do diagnóstico de câncer que pode levar à negação dos sintomas, os problemas de organização da rede de serviços e o acesso desigual às tecnologias diagnósticas contribuem para atrasos nos diagnósticos. Além disso, o fato de muitas crianças manterem seu estado de saúde inalterado no início da doença, bem como a manifestação de alguns tumores ser muito semelhante a diferentes doenças comuns na infância, também representam obstáculos ao diagnóstico precoce (BRASIL, 2012).

Para o enfrentamento do câncer, são necessários diferentes tipos de ações: educação em saúde em todos os níveis da sociedade; promoção e prevenção orientadas a indivíduos e grupos; comunicação e mobilização social; realização de pesquisas; formação de recursos humanos; gestão do Sistema Único de Saúde (SUS); apoio e estímulo à formulação de leis que permitam monitorar a ocorrência de casos. Para que essas ações sejam bem-sucedidas é necessário que estejam pautadas em informações oportunas e de qualidade (consolidadas, atualizadas e representativas) e em análises epidemiológicas a partir dos sistemas de informação e vigilância disponíveis (BRASIL, 2009; BRASIL, 2011).

Mirra (2005) ressalta a importância dos registros de câncer de base hospitalar e de base populacional para as políticas referentes ao câncer no Brasil, porém, menciona a necessidade de apoio técnico e financeiro, por parte das instituições governamentais como imprescindíveis para a realização dessas atividades.

Com relação aos registros de câncer no Brasil, Mirra (2005), cirurgião do Hospital A.C. Camargo, realizou um estudo histórico que retoma esses registros. Segundo o autor, a preocupação de se conhecer a extensão da mortalidade e a incidência do câncer na população brasileira é antiga. Em 1904, Sodré ${ }^{4}$ (1904 apud MIRRA, 2005) publicou o trabalho “Frequência do câncer no Brasil” abrangendo o período de 1894 a 1898, que é conhecido como a primeira manifestação a respeito do assunto no âmbito científico e acadêmico brasileiro. Já as primeiras publicações oficiais de mortalidade por câncer, pelo então

\footnotetext{
${ }^{4}$ SODRÉ, A. A. A. Frequência do câncer no Brasil. Brasil Médico, n. 18 v.3, p. 229-232, 1904.
} 
Ministério de Educação e Saúde, datam de 1944, contendo dados referentes ao período de 1929 a 1932. A respeito do Estado de São Paulo, por exemplo, os dados sobre mortalidade por câncer estão presentes desde 1898.

Inicialmente, foram predominantes as publicações sobre mortalidade por câncer, abrangendo estudos globais e de localizações tumorais, para as várias regiões do Brasil. O maior número de publicações voltadas para a mortalidade por câncer deve-se a uma maior disponibilidade do instrumento de informação, no caso, atestados médicos de óbito (MIRRA, 2005).

A partir da década de 1940, publicações referentes a casuísticas hospitalares de câncer surgiram em Belém, Curitiba, João Pessoa, Recife, Rio de Janeiro, Salvador, São Paulo e Ribeirão Preto. Entretanto, os registros hospitalares de câncer, propriamente ditos, surgiram somente a partir de 1980 (MIRRA, 2005).

\subsection{O TRATAMENTO}

Com relação ao tratamento de câncer, os avanços alcançados na área permitem que esta doença, antes vista como aguda e fatal, seja hoje considerada como crônica e passível de cura.

As possibilidades de tratamento compreendem três modalidades principais: cirurgia, quimioterapia e radioterapia.

No caso das cirurgias, elas são indicadas, principalmente, para os tumores sólidos, seja para remoção dos mesmos ou de parte deles.

A quimioterapia atua de forma a destruir as células do câncer, impedindo que elas cresçam ou se multipliquem.

Já a radioterapia utiliza a radiação ionizante como agente terapêutico, que é responsável por levar a célula doente à morte ou à inviabilidade biológica devido à perda de sua capacidade proliferativa (CAMARGO; LOPES, 2000). Como os tumores infantis são altamente proliferativos, eles são bastante sensíveis à radioterapia, porém, esta não é indicada para tratamento de crianças com idade inferior aos três anos devido aos riscos de causar déficits neurológicos.

Tanto a radioterapia como a quimioterapia não diferenciam células saudáveis de células neoplásicas e, por isso, geram efeitos colaterais. Os efeitos colaterais mais comuns 
são: mucosites, vômitos, infecções oportunistas, perda de cabelos e alterações na fisionomia (ANDRÉA, 2008).

Esses efeitos tóxicos variam de criança para criança e podem ser diferentes mesmo para crianças que estão recebendo o mesmo tratamento; porém, tendem a desaparecer gradualmente após o fim do tratamento. Além disso, o risco desses efeitos é normalmente menor do que o benefício de matar as células do câncer (HOSPITAL DO CÂNCER, 2003).

\subsection{REPERCUSSÕES PSICOLÓGICAS DO ADOECER EM PACIENTES E FAMILIARES}

O adoecimento desencadeia uma crise, que acontece quando uma pessoa entra em contato com uma situação nova e vitalmente transformadora - seja por perda ou expectativa de perda ou por aquisição ou expectativa de aquisição - desencadeando uma redução ou uma ampliação significativa do espaço no seu universo pessoal. No caso das crises por perda, os sentimentos despertados são de culpa e depressão, enquanto que as crises por aquisição geram sentimentos de inferioridade, insegurança e inadequação (SIMON, 1989).

Valle (1997) pontua que vivenciar uma doença grave é habitar um mundo que não foi escolhido pelo sujeito desse processo. No momento de adoecimento prevalecem exames clínicos, medicamentos, internações, afastamento de familiares e amigos, a pessoa perde sua liberdade, seu querer, deixa de ser ela mesma para confundir-se com todos, deixa de ser autêntica para ser impessoal, passa a ser submissa e dominada pelo mundo da doença.

Com relação especificamente ao câncer, a despeito dos avanços científicos e tecnológicos que permitem um aumento na possibilidade de cura, o câncer ainda carrega os estigmas do passado. A população associa o câncer à desfiguração, perda da função corporal, alteração de humor, angústia, crises financeiras, intensa dor e morte (BONAMIN, 1995; DEITOS; GASPARY, 1997).

Esse estigma mobiliza desconforto e causa impacto não só em pacientes e familiares, mas também em profissionais de saúde, a despeito de seus conhecimentos sobre os progressos na área de diagnóstico, tratamento e assistência.

Yamagushi (1994) salienta que quando o indivíduo se depara com o diagnóstico de uma doença que carrega o estigma da morte, a primeira reação tende a ser de medo de não ser curado e de que o câncer ocasionará sofrimento, dor e humilhação física. 
Com relação às crianças, as repercussões psicológicas do adoecimento em seus comportamentos são diferentes e singulares a cada uma delas: elas podem ficar mais agitadas ou mais quietas, ter pesadelos, mudanças de hábitos alimentares, alterações no desempenho escolar ou regressões como, por exemplo, voltar a chupar o dedo (HOSPITAL DO CÂNCER, 2003).

Apesar dessas singularidades, há alguns aspectos comuns nas experiências de crianças em situações de adoecimento: mudança no funcionamento do próprio corpo, contato com procedimentos médicos, com situações e pessoas desconhecidas, internação hospitalar, mudança na rotina de vida. Essas alterações podem gerar angústia e desorganização diante de um universo desconhecido. A criança, então, mescla informações recebidas com fantasias criadas por ela mesma com o objetivo de atribuir algum sentido a tudo o que está vivendo e, assim, conseguir mobilizar recursos de enfrentamento (FRANÇOSO, 2001).

O contexto hospitalar, por si só, possui algumas características que interferem no estado emocional dos pacientes. Chiattone e Sebastiani (1997, p. 124) pontuam:

[...] estresse constante; isolamento de figuras que geram segurança e conforto; relação com aparelhos intra e extracorpóreos; clima de morte iminente; perda da noção de tempo e espaço; perda da privacidade e da liberdade; despessoalização/perda da identidade e participação direta ou indireta no sofrimento alheio.

Para Sarti (1989), a criança hospitalizada tem duas fontes de ansiedade: externa e interna. A ansiedade externa está ligada a fatos concretos advindos do ambiente hospitalar, enquanto que a ansiedade interna decorre de estados de angústia ou ansiedade gerados pela doença ou pela ideia que a criança tem desta.

Chiattone e Sebastiani (1997) citam algumas reações psicológicas previsíveis às circunstâncias de adoecimento e hospitalização: perdas de sentimento de invulnerabilidade, de conexão com o mundo habitual, de aptidão e plenitude do raciocínio e de controle de si mesmo, além de ameaça à homeostase, sensação de desamparo, desesperança, estados de ansiedade, depressão, dependência, raiva, isolamento, negação e culpa.

Segundo Lipp et al. (1991), essas alterações potencializadas pela gravidade da doença e pela agressividade do tratamento podem desencadear reações de estresse, entre elas: retraimento, apatia, choro e irritabilidade.

Além disso, o afastamento do convívio social de origem e as interferências nos processos evolutivos da criança, que possibilitam conquistas autônomas, podem levar a perdas significativas para o psiquismo infantil de crianças hospitalizadas (TRINCA, 1987). 
De acordo com Azzi e Andreoli (2008), o impacto da hospitalização pode incidir em qualquer fase do desenvolvimento infantil. Porém, crianças com idade inferior a quatro anos podem ser mais vulneráveis a episódios de desestruturação por se encontrarem com recursos cognitivos e emocionais ainda pouco desenvolvidos para compreender a doença e a hospitalização. Já com relação aos adolescentes, o foco de dificuldade não é essa compreensão, mas a perda da privacidade e autonomia, o que é muito valorizado pelos jovens.

Como se pode perceber, os efeitos do adoecimento e da hospitalização estão relacionados a diferentes fatores, tais como: caráter agudo, crônico ou progressivo da doença; natureza da patologia; local de tratamento (domiciliar, ambulatorial ou internação); duração e impacto do tratamento. Já os fatores subjetivos, incluem: fase do desenvolvimento cognitivo e psicossexual em que a criança se encontra; características da personalidade; processos psicopatológicos anteriores; tolerância à dor, às frustrações e às incertezas; qualidade do vínculo estabelecido com pais e familiares; qualidade do suporte com o qual a criança pode contar e grau de informações que ela possui (AZZI; ANDREOLI, 2008).

Com relação às repercussões psicológicas nos familiares de pacientes com câncer, o diagnóstico, em geral, tende a gerar, além de ansiedade, medo, dúvidas e incertezas, uma alteração na rotina familiar, social e profissional de todos os membros.

Apesar de a doença ser vivenciada por um membro, também repercute na família, não sendo apenas um fato natural, mas possuindo caráter social. Romanelli (2003) explicita que a doença altera o cotidiano familiar, gerando desconforto para o enfermo e para os integrantes da unidade doméstica, além de estresse e problemas financeiros. Porém, a forma com que a doença atinge a vida doméstica varia de acordo com os atributos do doente e da família.

Os familiares manifestam reações emocionais frente ao adoecimento e ao tratamento da criança e, visando ao reequilíbrio diante da doença, buscam ajustar os seus papéis, o que frequentemente gera relações conflituosas. A criança doente torna-se o centro da família, modificando as hierarquias existentes no momento anterior à enfermidade. Há repercussões também nas relações conjugais, que perdem espaço para as relações parentais, sendo que o principal cuidador da criança tende a vivenciar sentimentos de culpa e sobrecarga física e emocional (CHIATTONE, 2001).

Para Azzi e Andreoli (2008), tanto os pais como os demais familiares se encontram em um determinado ciclo de suas vidas com suas expectativas históricas que foram construídas ao longo do tempo. Assim, a estabilidade familiar é colocada em cheque, pode haver dificuldade de reorganização devido à perda de liberdade e de autocontrole e, também, em razão das mudanças de papéis necessárias à manutenção da rotina de tratamento. Os autores enfatizam 
ainda que, devido à súbita desorganização, muitas famílias se encontram em processo de ruptura.

Segundo Lima (2004), os pais costumam sentir-se culpados pelo adoecimento do filho, sentem-se frágeis e impotentes em seu papel de cuidadores, têm dificuldades de elaboração psíquica e de manejo da situação, o que dificulta que eles ofereçam continência emocional ao paciente e os torna também necessitados de escuta e acolhimento.

De acordo com Carter e McGoldrick (1995), o ajustamento familiar diante do adoecimento de um ente querido depende de vários fatores, entre eles: a idade do paciente, o diagnóstico, sua função dentro da família, as relações individuais e a estrutura psicológica geral do sistema familiar; e envolve também as crenças, os padrões de funcionamento, os segredos e legados dessa família.

É importante mencionar que a família é uma instituição dinâmica e que, frente ao adoecimento e tratamento de um dos seus membros, tende a sofrer alterações emocionais de acordo com a situação em que o doente se encontra - remissão da doença, intercorrências, recaída da doença - o que faz com que fases de esperança se alternem com fases de desesperança.

O ser humano sofre limitações de seu ambiente e de sua corporeidade e, muitas vezes, precisa adaptar-se a elas, o que demanda esforços com intensidade e extensão variáveis para conseguir recuperar a homeostase perdida. Contribuem para esse enfrentamento, a autopercepção, as estratégias de cuidado desenvolvidas, a percepção do apoio social, o envolvimento familiar, a capacidade dos familiares para se reorganizarem diante de situações difíceis, as informações apropriadas e o acompanhamento psicossocial sistemático da criança e de seus familiares. Além disso, o ato de buscar o significado de suas vivências e a capacidade de transcender suas limitações através da consciência das situações que vivem, ajudam a elaborar e a integrar as suas experiências durante o tratamento (AZZI; ANDREOLI, 2008; FRANÇOSO; VALLE, 2000; VALLE, 2004).

\subsection{A PRÁTICA DE SAÚDE: A PREDOMINÂNCIA DO MODELO BIOMÉDICO}

No século XVII, o filósofo Descartes concebeu a realidade do mundo como uma máquina, defendendo uma separação entre fenômenos da natureza e fenômenos do espírito, uma separação entre mente e corpo (ALBUQUERQUE; OLIVEIRA, 2002; MARCO, 2003). 
Essa orientação científica da época marcada por uma visão mecanicista e reducionista influenciou o surgimento do modelo biomédico que constitui o alicerce conceitual da medicina ocidental (CAPRA, 1982).

No pensamento cartesiano, o corpo humano é visto como uma máquina constituída de partes separadas. $\mathrm{O}$ ato de curar uma doença seria equivalente à reparação da máquina, deixando de lado os aspectos psicológicos, sociais e ambientais do adoecer (ALBUQUERQUE; OLIVEIRA, 2002; CAPRA, 1982, CHIATTONE; SEBASTIANI, 1997).

Segundo Koifman (2001), a saúde, sob a perspectiva cartesiana, passou a ser vista como ausência de doença, sendo que se alcançaria a cura através da eliminação dos sintomas.

De acordo com Sanvito (1994), a medicina realizada a partir da perspectiva biomédica, de forma simplista, tentou reduzir a doença às funções biológicas, negligenciando questões socioculturais e ambientais. Como consequência, o médico perdeu de vista o paciente integral inserido em um contexto. Sanvito (1994, p. 17) complementa: "este modelo adota o seguinte figurino: 1) o doente como objeto; 2) o médico como mecânico; 3) a doença como avaria; 4) o hospital como oficina de consertos”.

De acordo com Chiattone e Sebastiani (1997), a divisão cartesiana, influenciando a prática médica, dificulta o tratamento dos pacientes como indivíduos totais, sob um enfoque holístico da saúde. Logo, o tratamento fica voltado para o corpo ou para parte desse corpo, desconsiderando aspectos psicológicos, sociais e ambientais relacionados ao adoecimento.

$O$ foco na qualidade técnica em detrimento da qualidade interacional e a multiespecialização associadas a uma visão reducionista e mecanicista trouxeram prejuízos ao relacionamento profissional-paciente: os profissionais passaram a ser vistos como os detentores do poder e responsáveis por decidir sobre o tratamento dos pacientes, além de oferecerem menor disponibilidade de tempo e contato a esses doentes (VALLE, 2004).

Marco (2003) ressalta que os inúmeros avanços técnicos e científicos na área da medicina têm causado uma desumanização na atuação em saúde. Segundo o autor, para um profissional contaminado pelo olhar biomédico, questões pessoais e sentimentos tendem a atrapalhar a investigação e a ação do médico, sendo, portanto, considerados banalidades.

Para Marco (2003, p. 39), o problema não é a especialização, considerada por ele como necessária, devido ao crescimento veloz do conhecimento e ao rápido desenvolvimento das diferentes áreas do saber, mas o “especialismo” - “uma fragmentação rígida e estática que bloqueia o trânsito entre diferentes áreas”. 
4.5 UMA PROPOSTA DE ATUAÇÃO EM SAÚDE: O MODElO BiOPSiCOSSOCIAL E A INTERDISCIPLINARIDADE

George Engel, em 1977, publicou um artigo que introduziu o chamado modelo biopsicossocial. Nessa visão, a saúde não é mais vista como um produto ou um estado, mas como um processo multidimensional no qual interagem permanentemente sistemas biológicos, psicológicos, culturais, ambientais e familiares. Nesse caso, o trabalho do médico não se limitaria a curar a doença, mas se ampliaria para o cuidado à saúde, considerando a pessoa doente no seu contexto vital (COLLANTES, 2001).

Uma visão sistêmica do indivíduo, em que se defendia a ideia de conciliar conhecimento científico e subjetividade, já havia sido proposta por Hipócrates, 400 a.C., mas acabou sendo deixada de lado, com a supervalorização do saber científico e da razão (VALLE, 2004).

No olhar de Hipócrates, a origem das doenças seria um desequilíbrio entre forças da natureza presentes dentro e fora da pessoa. A Medicina, assim, estaria centrada no paciente como um todo e em seu ambiente, sem relacionar a doença a perturbações de órgãos corporais específicos. Além disso, o “pai da Medicina” enfatizava a importância de uma boa relação médico-paciente e a interferência dessa relação no bem-estar dos doentes (ALBUQUERQUE; OLIVEIRA, 2002).

Em 1947, a Organização Mundial da Saúde (OMS) definiu saúde como o estado de completo bem-estar físico, psíquico e social e não só como a ausência de doença. Essa visão propõe que a doença seja vista como algo que afeta não apenas a dimensão física, repercutindo também no estado psicológico do indivíduo, no seu nível de independência e em suas relações sociais - fatores, esses, que extrapolam o objeto da saúde da medicina tradicional (GUYATT; FEENY; PATRICK, 1993; ORLEY; KUYKEN, 1994).

Pela perspectiva biopsicossocial, a doença, independente de sua origem orgânica ou psíquica, é considerada como uma desarmonia que bloqueia o dinamismo e o desenvolvimento do homem como um ser integral dentro do seu ambiente (CHIATTONE; SEBASTIANI, 1997).

Sendo assim, o modelo biopsicossocial é uma proposta de evolução de um sistema tradicional, centrado no médico e voltado para a cura da doença, para um modelo de "time", incluindo diferentes categorias profissionais com seus conhecimentos, habilidades técnicas e 
perspectivas distintas, mas todas voltadas para a promoção em saúde (BRUSCATO et al., 2004).

Em um contexto de adoecimento que repercute e causa transformações em toda uma estrutura familiar é importante que os pacientes e seus familiares possam contar com profissionais que os orientem e os acolham nesses momentos difíceis, que os vejam como seres humanos únicos com sua história, seus planos, suas expectativas, medos e angústias, indo além do foco exclusivo na doença.

Nesse cenário, atuar na área de saúde no século XXI exige a troca de conhecimentos, promovendo a interdisciplinaridade - reunião de disciplinas distintas articuladas em torno de uma mesma temática. É uma proposta de ir além da rigidez e do isolamento disciplinar, visando a abarcar o todo através de diferentes olhares sobre um mesmo fenômeno (GALVÁN, 2007).

Amaral (2002), ao estudar as vivências de médicos, aponta que, apesar da difusão sobre a importância de considerar o indivíduo como um todo, é possível observar que ainda é difícil para os profissionais considerarem a dimensão pessoal na relação profissional-paciente.

Nucci e Perina (2008), ao estudarem a visão de pensadores e analistas contemporâneos, constataram que os conhecimentos científicos e tecnológicos estão criando, contraditoriamente, isolamento, incompreensão e solidão entre os indivíduos, o que faz emergir um movimento de resgate da "humanidade" no ato de cuidar por parte dos profissionais de saúde.

De acordo com Romano (2007), a especificidade do saber, isoladamente, não consegue contemplar a realidade que é multifacetada. Nesse sentido, a atuação multiprofissional permite o não fechamento do profissional em seu saber, evitando uma compartimentalização do paciente.

Segundo Minayo (1991), nenhuma disciplina, por si só, dá conta do objeto a que perseguimos porque ele envolve, além dos aspectos biológicos, as relações sociais e as expressões emocionais e afetivas.

É importante mencionar que as equipes são estruturas dinâmicas que podem funcionar ora de forma mais integrada, ora de forma mais estratificada. Não é a equipe que é multi ou transdisciplinar, mas seu modo de operar que é definido de uma determinada maneira, em um determinado momento, sendo que existe a possibilidade de que, em situações de crise, haja um retrocesso para formas de funcionamento menos maduras (GALVÁN, 2007).

A diferença entre equipe multiprofissional multidisciplinar e equipe multiprofissional interdisciplinar é que, na primeira, o conjunto de disciplinas trata de uma dada questão, sem 
que os profissionais implicados estabeleçam efetivas trocas entre si (ALMEIDA FILHO, 2005). Já no trabalho interdisciplinar, as atividades são realizadas por um grupo de profissionais de diversas formações, que atuam de forma interdependente, através de comunicações formais e informais, que promovem transformações e enriquecimento na atuação dos mesmos sem deixar de lado que cada especialidade tenha suas potencialidades e limitações (ANGERAMI-CAMON, 2000; GALVÁN, 2007).

É importante mencionar, também, uma especificidade ligada ao trabalho com crianças e adolescentes com câncer, que é o desafio de cuidar de pacientes com uma doença crônica e que precisam continuar se desenvolvendo, apesar das enormes dificuldades impostas pela doença e pelo tratamento. Frente a uma doença que causa ameaça ou perda de sentimentos de segurança e controle, e que pode ocasionar reações disfuncionais por parte dos pacientes, é importante que se tenha uma equipe integrada que ofereça suporte, preparação e acompanhamento a esses pacientes (AZZI; ANDREOLI, 2008).

Apesar disso, atuar de forma interdisciplinar não é um objetivo de fácil alcance. Isso porque não basta, por exemplo, a síntese de saberes, mas é necessária a interface entre disciplinas. Além disso, envolve o questionamento da hegemonia do saber médico em detrimento das outras profissões da área de saúde; envolve também abrir mão da rigidez disciplinar e da ideia de segurança que um título profissional dá à identidade do indivíduo que também se confronta com os seus limites pessoais e com os limites de sua profissão (GALVÁN, 2007; SCHRAIBER, 1999).

Podemos depreender das ideias aqui apresentadas que, abandonar a ideia de ser dono do saber requer coragem do profissional de saúde, já que exige entrar em contato com sua própria vulnerabilidade. Apesar dessas dificuldades, abandonar essa postura abre portas para um relacionamento mais próximo entre profissionais e pacientes, permeado por uma escuta atenta e uma compreensão mais humana.

A atuação em equipe interdisciplinar exige, ainda, um questionamento da formação em saúde, já que os profissionais não encontram subsídios em sua formação acadêmica para a atuação interdisciplinar; eles não chegam à prática, instrumentalizados para esse tipo de atuação integrada, o que gera, muitas vezes, conflito por competição entre especialidades (ALMEIDA, 2000; BRUSCATO et al., 2004).

Os conflitos aparecem em situações em que há oposição de interesses, sentimentos ou ideias, gerando instabilidade entre os membros da equipe. Porém, é preciso levar em conta que as diferenças são importantes para a atividade criadora do grupo, possibilitando amadurecimento e inovação por parte de cada profissional (KITAJIMA; COSMO, 2008). 
É importante pontuar que a atuação multiprofissional, sem integração de saberes entre os profissionais de uma equipe, pode causar uma fragmentação do indivíduo, gerando ansiedade aos pacientes e familiares. Isso pode acontecer devido à falta de comunicação entre profissionais, ausência de experiência no trabalho integrado e aspectos da própria instituição, como tempo, espaço, recursos materiais e humanos (CHIATTONE; SEBASTIANI, 1997).

Chiattone e Sebastiani (1997) ressaltam, ainda, outros aspectos que dificultam a atuação interdisciplinar: ausência de definição específica sobre o papel de cada membro dentro da equipe, ausência de entrosamento entre os profissionais, competitividade pueril, relações de poder e hierarquia. Esses fatores podem gerar ressentimento, intolerância e dificuldade na comunicação entre os profissionais. Os autores explicam que o autoritarismo, muitas vezes, está relacionado à imaturidade, onipotência e insegurança do profissional. Os autores não desconsideram a necessidade de uma hierarquia dentro da instituição, mas defendem uma horizontalização da assistência e uma hierarquia dinâmica, que se altera dependendo do momento e da necessidade do paciente.

De acordo com Galván (2007), a integração disciplinar exige indivíduos maduros, dotados de abertura e curiosidade, de desejo de aprender e de trocar conhecimentos, com objetivos comuns e partilhados. A autora complementa que uma equipe de saúde atinge a maturidade quando possui capacidade de se apropriar das potencialidades e contribuições de cada indivíduo que a compõe, de forma interativa, sendo que cada parte deste todo conta com uma permeabilidade que lhe permite modificar e ser modificada no processo de construção de um saber e um fazer que transcende o limite do individual.

Há destaque ainda, na literatura, de outros pré-requisitos necessários na postura dos profissionais para que uma equipe sólida possa ser estruturada e, assim, oferecer uma assistência de qualidade. Entre eles: disposição para enfrentar os desafios necessários à formação de uma equipe; conhecimento e reconhecimento por todos os profissionais envolvidos; resgate da identidade profissional na relação funcional com a tarefa grupal; consideração da prática dos demais como interdependente e complementar; manutenção de um diálogo contínuo; desenvolvimento de habilidades interpessoais; constante aprimoramento técnico; desenvolvimento de sentimento de pertença ao grupo (ALMEIDA, 2000; BRUSCATO et al., 2004).

Para que essas mudanças possam acontecer, é importante que haja aproximação entre teoria e prática, ciência e assistência, além de se repensar a formação dos profissionais de saúde e promover o desenvolvimento de recursos emocionais e comportamentais desses 
profissionais ligados à prática assistencial (MACEDO, NOGUEIRA-MARTINS; NOGUEIRA-MARTINS, 2008).

\subsection{CUIDADO EM SAÚDE: O DESGASTE DO PROFISSIONAL}

A existência de condições de trabalho desencadeadoras de sofrimento, estresse e ansiedade em profissionais da saúde é uma realidade. Segundo Pitta (1999), há um conhecimento milenar de que o trabalho pode causar adoecimento.

Nogueira-Martins, L.A. (2003) e Nogueira-Martins, M.C.F. (2003), ao realizarem pesquisas na área de saúde, afirmam que o sofrimento psicológico é inerente e comum a todos os profissionais que atuam no contexto hospitalar.

No entanto, as repercussões na saúde desses trabalhadores ainda são pouco conhecidas. Pude perceber que as lacunas são maiores quando se tratam de psicólogos, nutricionistas, fisioterapeutas, assistentes sociais e terapeutas ocupacionais, já que há um maior número de estudos feitos com médicos e enfermeiros.

Andreis, Chitero e Silva (2008) ressaltam que, em um cenário marcado por diferentes formações, linguagens, prioridades, valores, concepções de mundo e posições hierárquicas, os profissionais ficam expostos a fontes de estresse adicionais.

Entre os elementos identificados, que funcionam como fontes de insatisfação e de sofrimento psíquico, encontram-se: instabilidade e precarização do contrato de trabalho, ritmo intenso e jornadas de trabalho prolongadas, privação do sono, baixa remuneração, pressão repressora e autoritária, fragmentação de tarefas, contato intenso com dor, sofrimento e morte, sentimentos de culpa, frustração e impotência frente à perda de pacientes, comportamento idealizado, limitações do conhecimento científico e medo de errar (MACHADO, 1997; MENZANI; BIANCHI 2005).

Um estudo, realizado por Sobrinho et al. (2006) com 7.897 médicos residentes em Salvador (Bahia), mostrou que, dentre as queixas relacionadas à saúde mental, mencionadas pelos profissionais, destacaram-se: cansaço mental, sonolência, esquecimento, nervosismo, insônia e sofrimento psíquico. A respeito das questões relacionadas à demanda psicológica, destacaram-se: a existência de volume excessivo e ritmo acelerado de trabalho, tempo insuficiente para realização das tarefas, exigência de rapidez no trabalho, exposição a demandas conflitantes feitas por outras pessoas e exigência de esforço físico. 
Com relação ao trabalho de enfermeiros, Menzani e Bianchi (2005) relataram que o acúmulo de funções, as atividades burocráticas e a limitação do tempo para realizar as tarefas são fatores que geram conflitos e esgotamento para os enfermeiros. Revelaram, ainda, que enfrentar a morte de pacientes, atender e orientar familiares de pacientes críticos são atividades que provocam grande sofrimento psíquico nos profissionais.

Um projeto desenvolvido na Santa Casa de São Paulo, junto a uma equipe de enfermagem, fez um levantamento de dados sobre as demandas desses profissionais relacionadas à prestação da assistência. A respeito da relação dos enfermeiros com os pacientes e familiares, os profissionais revelaram dificuldades para impor limites, para lidar com questionamentos e para enfrentar constantes exigências por atenção, além de despreparo emocional para prestar informações realistas sobre a doença e o tratamento. Por último, demonstraram possuir demandas no tocante aos demais profissionais, entre elas: dificuldades no manejo de ambiente de trabalho estressante, justaposição do papel profissional com o envolvimento pessoal e eventuais problemas de relacionamento com os colegas de trabalho (AMORIM; LOPES; BRUSCATO, 2004).

As autoras Amorim, Lopes e Bruscato (2004) comentam também sobre a relação existente entre estresse e o contexto de saúde, devido aos seguintes aspectos: rápidas mudanças tecnológicas que fazem com que o profissional entre em contato com as limitações de seu próprio conhecimento científico; competitividade e busca incessante de resultado, o que acarreta aumento da carga de trabalho; constante contato com as expectativas de pacientes, de familiares e dos próprios membros da equipe; além do contato direto com doença, dor, sofrimento e morte, que levam o profissional a se colocar diante de suas próprias questões de vida, morte, saúde, doença, conflitos e frustrações.

A respeito de expectativas ligadas aos próprios profissionais, Doró e Pasquini (2000) relembram que, desde a antiguidade, há uma crença voltada para o médico-divino, e não para o médico enquanto ser humano. Estendendo para as demais profissões, podemos pensar nas repercussões que essas expectativas idealizadas de pacientes e familiares geram nos profissionais de saúde, que são seres humanos falíveis e, muitas vezes, impotentes.

Mas há também as expectativas dos próprios profissionais de saúde em relação a si mesmos. Valle (1997) aponta que há uma contradição entre a expectativa que o profissional de saúde tem de si - de ser forte e dar conta de tudo - e a constatação que este próprio profissional tem de sua vulnerabilidade. Assim, envergonhado por não corresponder à idealização, ergue uma barreira ao seu redor, evitando qualquer expressão de suas inquietações e isolando-se em sua fragilidade. 
Em um estudo realizado com médicos com o intuito de compreender as vivências destes diante do diagnóstico de câncer infantil, Caparelli (2002) encontrou que estes profissionais convivem com a negação, a raiva, a culpa, a impotência, têm sintomas depressivos e dificuldades para identificar e lidar com seus próprios sentimentos.

Santos (2003) ressalta que, ao lidar com o câncer, os profissionais de saúde entram em contato com a ambivalência, já que foram treinados para ter uma perspectiva de cura, mas nem sempre o câncer permite essa perspectiva.

O convívio frequente com a dor, a morte e a finitude da existência lembram os profissionais, o tempo todo, que eles também são vulneráveis, que a morte bate à porta de todos e não dá para se esconder dela para sempre.

De acordo com Lautert, Chaves e Moura (1999), no ambiente hospitalar é comum encontrar equipes de trabalho indiferentes, apáticas e cansadas, queixando-se de estresse e desmotivação, gerando, por vezes, conflitos e insatisfação em alguns profissionais.

Quando um profissional começa a perceber que as demandas do trabalho são superiores aos recursos de que dispõe para enfrentá-las, surge um quadro de tensão considerado como a primeira fase da Síndrome de Burnout, caracterizada pela exaustão física e emocional do profissional diante dos estressores no trabalho (LAUTERT; CHAVES; MOURA, 1999).

A Síndrome de Burnout não é equivalente ao estresse ocupacional, já que essa síndrome é um processo que acontece após várias tentativas de lidar com determinadas condições de estresse e que, apesar dessas tentativas, esse estresse não pôde ser mediado (RABIN; FELDMAN; KAPLAN, 1999).

De acordo com Rodriguez-Marín (1995), a Síndrome de Burnout nos profissionais de saúde ocorre pelo contato intenso com pacientes e familiares em sofrimento, sendo estas relações geralmente acompanhadas de sentimentos de tensão, ansiedade, medo e até mesmo de hostilidade encoberta.

São várias as causas do Burnout, entre elas: a natureza do trabalho (lidar com doença grave e com situação emocional de pacientes e familiares, conviver com a morte de indivíduos); viver numa cultura profissional em que se exige sempre estar bem; vivenciar problemas tanto com equipe como com pacientes (alto número de demandas, tempo insuficiente para prestar um cuidado de qualidade, problemas de comunicação e competição entre profissionais); características de personalidade (muito ou pouco envolvimento, dificuldade de pedir ajuda e de ter tempo fora do hospital, não compartilhar pensamentos, medos e culpa com outros profissionais ou com pessoas fora do hospital); dentre outros 
aspectos relacionados (desejo de mudar de emprego versus sentimento de risco financeiro, não ter tempo para descanso, enfrentar problemas na vida privada e no trabalho ao mesmo tempo) (SOCIEDADE INTERNACIONAL DE ONCOLOGIA PEDIÁTRICA - SIOP, 2000).

Um profissional em burning-out apresenta postura fria e distante, comprometimento de sua autoestima, oferece cuidados impessoais, demonstra indiferença para com as necessidades e sofrimentos dos outros, sente decepção e frustração. Além disso, foca em tarefas mecânicas com o intuito de conseguir um afastamento psicológico para não se deparar com sua fragilidade (MACEDO; NOGUEIRA-MARTINS; NOGUEIRA-MARTINS, 2008; VALLE, 1997).

A SIOP (2000) orienta sobre formas de prevenção da Síndrome de Burnout no contexto de Oncologia Pediátrica, porém, afirma a necessidade de adequação dessas orientações às necessidades singulares de cada indivíduo. É importante considerar que as sugestões propostas envolvem posturas aplicadas tanto no ambiente de trabalho como fora dele.

Para o contexto de trabalho, a SIOP (2000) propõe: definição de limites pessoais em termos de tempo e energia, evitando envolvimento excessivo; utilização de mecanismos para controlar estressores do trabalho dentro de hospital; uso de sistemas de apoio formal e informal; compartilhamento de necessidades com colegas e supervisores; comunicação regular com colegas, enquanto trabalha, como forma de apoio social; promoção de encontros com a equipe em momentos de transições críticas/importantes dos pacientes; engajamento em grupos sociais no trabalho; promoção de afastamentos da equipe para reciclagens.

Já para contextos que extrapolam o local de trabalho, a SIOP (2000) sugere: equilíbrio entre vida profissional e pessoal; dedicação à família; relaxamento; diversão; períodos de lazer para propiciar que volte para o trabalho bem física e mentalmente; ter consciência de que os colegas de equipe têm vida pessoal e também precisam de momentos de lazer.

Segundo Bianchi (1999), muitas vezes, não é a profissão em si que é estressante, mas a forma como a pessoa se insere no trabalho e nas condições de realização do mesmo, sendo, portanto, interdependente da avaliação da pessoa e do trabalho em si.

Ao avaliar a atuação dos profissionais em hospitais, é necessário ir além da própria atividade profissional e observar fatores diversos, como: tipo de trabalho desenvolvido, condições institucionais e perfil do profissional de saúde. Todas essas variáveis, isoladas ou conjuntamente, podem exercer impacto na condição emocional dos membros da equipe e em seus desempenhos junto aos pacientes (AMORIM; LOPES; BRUSCATO, 2004).

Melo e Valle (1998) afirmam que o ambiente hospitalar é tido como espaço de tensão: pacientes e familiares veem-se preocupados com a doença, com o futuro, com suas 
responsabilidades pessoais, custos e consequências do tratamento, enquanto que os profissionais de saúde costumam estar em contato constante com a morte e envoltos em dilemas relacionados ao cuidado em saúde.

Martins (1991) defende que os médicos deveriam ser incluídos nos grupos humanos mais vulneráveis, assim como crianças e índios. Porém, ressalta que os ataques a esses profissionais advêm, em maior parte, de seus próprios mundos internos, por exemplo, pela ilusão de onipotência que permeia o universo da medicina.

De acordo com Valle (2004) não só os pacientes e familiares passam por momentos difíceis, mas também os profissionais da saúde sofrem ao entrarem em contato com diferentes situações, cada um à sua maneira e de acordo com seus recursos interiores e com o momento em que vivem. Os sentimentos despertados nos profissionais de saúde, muitas vezes, são semelhantes àqueles vivenciados pelos pacientes e seus familiares, já que esses profissionais também manifestam negação, minimização da doença, raiva, frustração pela limitação de seus recursos pessoais, sintomas depressivos, impotência, culpa e pensamentos mágicos.

Andreis, Chitero e Silva (2008) citam algumas circunstâncias ansiogênicas ligadas especificamente à prática médica, mas é possível estendê-las às demais profissões de saúde: contato íntimo com doença, sofrimento, desamparo e morte, que são situações muito temidas pelos seres humanos. As autoras complementam que, devido à carga emocional e à vulnerabilidade, os profissionais de saúde correm o risco de desenvolver reações psicológicas perturbadoras, dolorosas e prejudiciais.

Silva e Andreoli (2008, p.116) ressaltam que “os profissionais de saúde precisam estar atentos às suas próprias reações, evitando desgastes e adotando estratégias de enfrentamento eficientes".

De acordo com Nucci e Perina (2008), os profissionais levam para sua prática clínica, seus valores, crenças, medos e fantasias, que influenciam no cuidado e nas intervenções ao paciente e aos seus familiares.

Remen (1993) ressalta que os médicos não encontram apoio para buscar o significado que a doença tem para seu paciente e nem mesmo o significado que seu trabalho profissional tem para si mesmo. Porém, salienta a importância de buscar esse senso de significado como fonte de apoio para enfrentar momentos difíceis. Complementa que a perda do significado que está oculto em cada tarefa acontece quando sabemos o que temos que desempenhar, mas esquecemos o que nos levou a fazer aquilo e o porquê de estarmos fazendo. E ainda, que resgatar esse sentido é essencial para que as tarefas de cuidar de uma pessoa voltem a ser significativas e promovam um melhor nível de bem-estar ao doente. 
Merece destaque o fato de que a significação não é estática. Um mesmo indivíduo pode, ao longo do tempo, atribuir um novo significado ao que está vivendo ou viveu e, ainda, indivíduos diferentes podem atribuir os mais diversos sentidos a uma mesma situação.

A natureza da doença pode permanecer imutável, dolorosa, difícil e assustadora, mas a possibilidade de descobrir um significado especial amplia a experiência do indivíduo, permitindo, por exemplo, repensar sua vida (REMEN, 1993).

Para Rosa e Carlotto (2005), realizar atividades profissionais em hospitais exige um maior controle mental e emocional se comparado às demais profissões, pelo fato de os profissionais estarem sempre expostos a estressores ocupacionais que interferem em seu bemestar.

Para Gauderer (1981), o médico, por estar em contato frequente com a morte, a dor, a angústia e o sofrimento, desenvolve mecanismos de defesa para conseguir lidar com a própria angústia, com seu sofrimento e com a lembrança da possibilidade de sua própria morte.

A respeito especificamente dos médicos, segundo Quintana, Cecim e Heinn (2002), a maioria deles faz uso do isolamento das emoções para conviver com a armadilha de estarem cotidianamente em contato com a morte, apesar de não terem sido preparados para lidar com ela. Além do isolamento das emoções cita, ainda, a negação e a racionalização como outros mecanismos defensivos utilizados por esses profissionais.

De acordo com estudo realizado por Kirschbaum e Silva (1998), os enfermeiros fazem uso de recursos de enfrentamento, tais como: religião ou alguma forma de ajuda espiritual; passatempos como passeios, execução de trabalhos manuais, leitura e meditação e fazem uso do choro como válvula de escape. Apenas uma pequena parcela dos enfermeiros relatou não misturar problemas do trabalho com sua vida pessoal.

Outros mecanismos defensivos utilizados pelos profissionais da saúde para diminuir a ansiedade, a culpa, as dúvidas, as incertezas em seu trabalho e para protegê-los de ameaças que perpassam um caminho de intenso sofrimento, são: fragmentação da relação técnicopaciente; negação de sentimentos e da importância do indivíduo; tentativa de eliminar decisões e reduzir o peso da responsabilidade; embotamento emocional; isolamento profissional; negação das dificuldades e incertezas associadas à atuação profissional; ironia e humor negro, uso de conhecimento científico e de objetividade (MARTINS, 1991; PITTA, 1999; VALLE, 2004).

Valle (1997) afirma que os profissionais adotam uma postura fria e distante, oferecem cuidados impessoais, focam em tarefas mecânicas com intuito de conseguir um afastamento psicológico para não se depararem com sua fragilidade. Pitta (1999) complementa que o 
profissional se distancia, reduzindo a intimidade com o paciente, pois quanto maior a intimidade, maior será a sensibilidade do profissional à vivência da angústia.

Perestrello (1996) defende uma distância crítica, que permita ao médico estar com o paciente durante a consulta, mas, após o término da mesma, conseguir desligar-se para atender outro paciente ou cuidar da vida pessoal.

É preciso destacar que não só os médicos, mas também os demais profissionais que atuam com pacientes com câncer apresentam dificuldades para encontrar um ponto de equilíbrio, sem estacionar na distância que esteriliza afeto e apoio ou na proximidade excessiva que impede o discernimento eu-outro, dificultando olhar aquele que está diante de si em suas necessidades singulares.

O uso de recursos defensivos nas relações interpessoais é natural e, muitas vezes, necessário para o desempenho das atividades profissionais. No entanto, eles não podem ser usados de forma rígida e indiscriminada, porque isso pode comprometer a qualidade da escuta e a capacidade de se vincular a colegas, pacientes e familiares (ANDREIS; CHITERO; SILVA, 2008).

Ferreira (1996) aborda, além das dificuldades que o profissional enfrenta ao conviver com os pacientes com câncer, a gratificação presente nesta relação: o contato humano e a participação na melhora de um paciente.

Em um cenário onde se exige atenção constante dos profissionais da saúde, disponibilidade para seus pacientes, escuta empática, habilidade para lidar com a agressividade de pacientes e familiares, somadas às exigências e pressões da instituição, à sobrecarga física, ao contato direto com o sofrimento, além de ausência de formação adequada com relação à humanização dos cuidados na área de saúde, torna-se necessário buscar compreender como estão esses profissionais que atuam com pacientes com câncer.

Santos (2003) ressalta a importância de se estar atento às condições emocionais de profissionais de saúde, já que o fato de estar próximo da dor do outro, aproxima-os de seu próprio sofrimento, o que pode levá-los, em alguns momentos dessa trajetória de trabalho, a esbarrarem nos limites da sanidade.

Para que o trabalho possa ser exercido com prazer e não apenas com sofrimentos, devem ser ajustadas as exigências do processo de trabalho com a estrutura psíquica de cada um, criando possibilidades de transformar a realidade segundo os próprios desejos, atribuindo sentido e resgatando o significado da prática profissional (DEJOURS, 1987; DEJOURS, 1989). 


\section{A TRAJETÓRIA METODOLÓGICA: UM CAMINHO PARA A COMPREENSÃo DO FENÔMENO}

\subsection{O MÉTODO FENOMENOLÓGICO}

Fenomenologia, palavra de origem grega phainomenon (o manifesto, o que se mostra tal como é) e logos (discurso esclarecedor), significa o estudo daquilo que se mostra diretamente à consciência.

Esse enfoque metodológico, que orientará este estudo compreensivo, teve suas bases lançadas no final do século XIX por Franz Brentano e Wilhelm Dilthey. Estes filósofos não concordavam com a utilização de métodos das ciências naturais pelas ciências humanas (DARTIGUES, 1992; GIORGI, 1978).

Vale pontuar que, até esse momento, o método experimental era o único considerado científico. Nessa perspectiva, sujeito e mundo, cientista e objeto seriam completamente separados e independentes, e o acesso a eles seria feito através da objetividade e da anulação da subjetividade. O mundo existiria por si próprio e o ser humano seria um objeto entre outros na natureza, portanto, sendo governado por leis naturais e por isso, passível de ser investigado pelo mesmo método utilizado pelas ciências da natureza (FORGHIERI 1984).

Porém, no século XIX, começaram a surgir questionamentos sobre os fundamentos e o alcance da ciência, da maneira como era concebida pelo Positivismo, uma das principais correntes defensoras do método experimental como único caminho para produção de conhecimento válido. Despontava o reconhecimento de que o sujeito, com sua vida psíquica imediata e seu engajamento histórico não seria passível de objetivação e universalidade (DARTIGUES, 1992).

Franz Brentano e Wilhelm Dilthey criticavam as ciências humanas e, notadamente, a Psicologia pelo fato de essas fazerem uso de métodos das ciências da natureza sem discernir a diferença entre os objetos de estudo (DARTIGUES, 1992; GIORGI, 1978).

Então, no final do século XIX, o matemático e filósofo Edmund Husserl entrou em contato com as ideias de Brentano e, no início do século XX, propôs uma nova forma de acessar o conhecimento - a Fenomenologia. Esta seria uma terceira via entre o discurso especulativo da Metafísica, dotado de abstrações e construções teóricas, e o Positivismo com sua objetividade, previsibilidade e neutralidade, que anula a subjetividade e tem como foco o controle para se chegar a uma verdade absoluta (DARTIGUES, 1992). 
Segundo Dartigues (1992), na visão de Husserl, as ciências humanas apresentavam lacunas e insuficiências, devido à tentativa de se transportar os métodos das ciências naturais para as ciências humanas, pois isso estaria aniquilando a especificidade de seu objeto - a dimensão subjetiva.

A crítica ao método experimental, tal como é utilizado pela Psicologia, refere-se à comparação que ele faz do ser humano com outros objetos da natureza, tornando-o passível de observação, controle e objetivação. No entanto, os fenômenos humanos não podem ser apreendidos em sua totalidade apenas pela observação de seus aspectos externos, pois, assim, deixaríamos de considerar a experiência vivida, à qual o pesquisador tem acesso através do próprio sujeito que atribui significados ao seu existir (FORGHIERI, 2009).

A Fenomenologia distingue-se, essencialmente, da concepção de ciência veiculada pelo Positivismo da época de seu surgimento, que a entendia como um corpo de conhecimento constituído por proposições cientificamente comprovadas por meio de parâmetros da lógica, baseadas na quantificação objetiva e na neutralidade do pesquisador, atribuindo à teoria, a faculdade de explicar e predizer os fatos, além do estatuto de orientador das perguntas formuladas pelo cientista diante da realidade (BICUDO, 1994).

É possível compreender, a partir das ideias aqui apresentadas que, para a Fenomenologia, tanto a Metafísica com suas abstrações do mundo concreto e com sua busca por verdades absolutas, como o Positivismo com seu foco na mensuração, generalização, neutralidade e objetividade, geram um distanciamento das vivências humanas, o que impede a compreensão de cada ser humano em sua singularidade e a compreensão do homem enquanto um contínuo vir-a-ser.

Critelli (2007) alerta que a modernidade ocidental tende a solicitar da ciência a mensuração precisa do real, oferecendo as causas da realidade, classificando-a e padronizando-a, como forma de nos proporcionar segurança. Porém, essa tentativa de uniformizar o real através de uma lógica exclusivista e categórica, opera um “aprisionamento do ser”.

A Fenomenologia não desconsidera a importância do método científico tradicional, considerando-o útil para analisar fatos observáveis, passíveis de serem controlados, manipulados e mensurados. A crítica destina-se ao modo como esse método é utilizado para pensar o homem. Assim, ela surge como um modo diferente de olhar o que é peculiarmente humano. 
É preciso destacar que a Fenomenologia, portanto, corresponde a um modo de investigar alternativo às posturas "clássicas" que, à luz do Positivismo, têm dominado o cenário acadêmico (GARNICA, 1997).

Diferentemente da pesquisa positivista destinada a gerar conhecimento objetivo através do controle de regras de ação, da neutralidade do pesquisador e do rigor nos procedimentos, nas abordagens qualitativas não há uma preocupação única e/ou aprioristicamente baseada em princípios, leis e generalizações, mas sim um movimento de compreensão do que o observador-investigador avalia como elementos significativos (GARNICA, 1997).

A Fenomenologia representa um método entre outros métodos qualitativos. Desde a década de 1980, tem sido observada uma popularização da metodologia qualitativa, um reflexo da mudança de paradigma científico das ciências naturais para as ciências humanas (ALVES, 2003).

Martins e Bicudo (2005) ressaltam que, por se tratar de uma pesquisa qualitativa, o pesquisador não se preocupa em alcançar generalizações. Em vez disso, volta-se para a especificidade, a peculiaridade, o individual, visando a compreender as qualidades essenciais do fenômeno em estudo.

Segundo Turato (2005), o método qualitativo aplicado à saúde visa a acessar significados individuais e coletivos. Os significados apresentam uma função estruturante: a partir do significado das coisas, as pessoas organizam suas vidas. Os pesquisadores qualitativistas não buscam explicar ocorrências, mensurar comportamentos ou correlacionar quantitativamente eventos da vida de pessoas, mas sim, conhecer vivências e representações que cada um tem de suas experiências.

A Fenomenologia não é um sistema filosófico ou um conjunto de ensinamentos, mas um modo de pensar, apreender e investigar o mundo. Trata-se de um método que pretende alcançar o fenômeno através de uma visão imediata, espontânea, pré-reflexiva; sem separar sujeito e objeto, buscando acessar a totalidade no vivenciar imediato da vida cotidiana (FORGHIERI, 1984; FORGHIERI; 2009).

Busca acessar o conhecimento propondo o não distanciamento do homem e visa a captar a forma com que cada um, dotado de singularidade, experiencia o mundo, ou seja, a sua vivência de uma situação.

A Fenomenologia movimenta-se na direção contrária ao movimento da ciência tradicional: em vez de contemplar o universo de essências estáticas, acabadas, já prontas, eternizadas ao longo do tempo, logo a históricas, destina seu olhar para a análise do 
dinamismo presente no próprio homem que doa sentido aos objetos do mundo (DARTIGUES, 1992).

Segundo Dartigues (1992), na visão de Husserl, homem e mundo são indissociáveis: o mundo constitui-se enquanto é percebido por uma consciência intencional, não tendo existência própria fora da atribuição de significado do ser humano.

Dartigues (1992, p. 18) pontua que:

[...] a consciência é sempre consciência de alguma coisa, que ela só é consciência dirigida para um objeto [...] por sua vez o objeto só pode ser definido em sua relação à consciência, ele é sempre objeto-para-um-sujeito.

Não existe uma consciência pura, separada do mundo como pregavam os racionalistas, mas também não há um objeto em si, independente da visada da consciência, como diziam os empiristas. No olhar fenomenológico, o objeto é para um sujeito que lhe doa significados (BRUNS, 2003).

A noção de Intencionalidade da Consciência estabelece uma nova relação entre sujeito e objeto, homem e mundo, pensamento e ser, ambos inseparavelmente ligados. Segundo Penha (2004, p. 28-29), através dessa noção, Husserl busca superar a dicotomia sujeito-objeto e procura derrubar um dos pressupostos básicos da Psicologia clássica:

Segundo esta, a consciência abriga imagens ou representações dos objetos que afetam nossos sentidos, nela se depositando como uma espécie de conteúdo. É como se os objetos que se encontram no mundo exterior penetrassem na consciência e aí permanecessem sob a forma de imagens. Husserl se insurge contra tal concepção, pois aceitá-la significa reduzir a consciência à mera passividade, quando, na verdade, ela é liberdade, portanto, ativa, cabendo-lhe, por isso mesmo, dar um sentido às coisas. A consciência, desse modo, já se encontra voltada para os objetos, orientada em sua direção de forma imediata, existe visando a algo, dirigindo para alguma coisa.

Segundo Souza e Boemer (2005), fundamentadas em Heidegger, o ‘ser’ está inserido em um mundo no qual foi lançado e o habita, de forma que não há como conceber um ser isolado, sendo sempre um 'ser-no-mundo'. Dessa maneira, a Fenomenologia preocupa-se com a maneira como esse ser vive o seu ser-com-os-outros - como ele se relaciona, atua, sente e vive com seus semelhantes no mundo.

O homem é um ser-no-mundo, existe em relação a algo ou a alguém, vive num certo espaço e num certo tempo e é capaz de transcender, atribuindo significados e dando sentidos à 
sua existência, diferentemente da visão do método experimental para o qual o objeto carrega em si mesmo o seu sentido (FORGHIERI, 2009).

Martins e Bicudo (2005) diferenciam: na pesquisa voltada para as ciências naturais, os fatos são concebidos como independentes da consciência dos indivíduos, enquanto que na pesquisa fenomenológica, os dados somente existem enquanto resultados de significados atribuídos pela consciência a partir da tematização do sujeito sobre o evento.

Não existe a coisa independente de um ponto de vista unilateral e variável através do qual ela se apresenta a alguém. Quando eu vario minha perspectiva subjetiva sobre um determinado objeto, o que obtenho é outra perspectiva igualmente subjetiva - o objeto estará sempre preso a um ponto de vista (MOURA, 2008).

A percepção de um fenômeno não se dá no vazio, pressupondo a necessidade de um estar-com-o-percebido; o que é visto não prescinde de ser olhado; solicita, para tanto, uma consciência atenta que o veja (BICUDO, 1994).

Logo, a intencionalidade está intimamente ligada à subjetividade. A noção de intencionalidade, que permite que diferentes pessoas atribuam os mais diversos significados a uma mesma situação, reitera a impossibilidade de considerar como "absolutos" aspectos que dizem respeito à existência humana. Além disso, faz com que a objetividade, a neutralidade, a generalização e a padronização, tão almejadas pelo método científico tradicional, percam seu espaço como objetivos a serem alcançadas quando o objeto de estudo é o ser humano.

[...] não há fatos com a objetividade pretendida, pois não percebemos o mundo como um dado bruto, desprovido de significados; o mundo que percebo é um mundo para mim. Daí a importância dada ao sentido, à rede de significações que envolvem os objetos percebidos: a consciência "vive" imediatamente como doadora de sentido (ARANHA; MARTINS, 1993, p. 171).

De acordo com Capalbo (1994, p. 193), “é graças à intuição que se dá o preenchimento de uma significação vazia, ou seja, dá-se a atribuição de significação por parte da subjetividade”.

A Fenomenologia aplicada à pesquisa permite apreender a realidade a partir do significado desta para uma subjetividade intencional, um indivíduo que é, ao mesmo tempo, ator e protagonista de sua vivência (HOLANDA, 2003).

É pelo fato de o ser humano ser dotado de uma consciência intencional, que existe o que a Fenomenologia nomeia como "fenômeno". 
Fenômeno é o que se mostra em si mesmo, um mostrar-se que pode se dar de várias maneiras, dependendo do acesso que se tem a ele (MARTINS; BICUDO, 2005). É o sentido que o homem atribui à sua experiência vivida (VALLE, 1997). É um modo subjetivo de doação, sempre reportado a um ponto de vista parcial e mutável (MOURA, 2008).

Diferentemente do fenômeno, o fato é o que afirma ser existente na realidade: são eventos, ocorrências, dados empíricos já apreensíveis pela experiência, observáveis e mensuráveis (MARTINS; BICUDO, 2005; RUDIO, 2001).

Enquanto o fato equivale ao acontecimento, sendo imutável, o fenômeno é passível de transformação através da ressignificação. A ressignificação representa um novo olhar para um mesmo acontecimento, atribuindo um novo sentido, o que proporciona pensar em novas atitudes diante da mesma circunstância.

A Fenomenologia caminha no sentido de abordar o fenômeno sem parcializá-lo ou explicá-lo através de conceitos ou crenças prévias. Sua intenção é abordar aquilo que se manifesta por si mesmo, interrogando-o, descrevendo-o e procurando captar sua essência (MARTINS; BICUDO, 2005).

Para acessar o fenômeno, é importante buscá-lo no que Husserl denomina mundovivido, ou seja, na instância primeira dos fenômenos psicológicos, experiência básica, primordial.

A Fenomenologia propõe o retorno ao mundo-vivido, ao diretamente experimentável, ao pré-científico, às coisas mesmas, recolocando o sujeito no seu lugar de destaque enquanto subjetividade (VALENTINI, 1984).

Valle (1997) aponta que o mundo-vivido é o modo como o homem experimenta e significa, de forma imediata, o mundo onde desfila sua vida e figura seu dia-a-dia, anterior a qualquer reflexão sobre esse mundo.

Segundo Von Zuben (1984), o retorno às coisas mesmas é voltar ao mundo que antecede a reflexão, atendo-se ao irrefletido, ao mundo vivido, sobre o qual o universo da ciência e do conhecimento se constrói. A “coisa mesma” é entendida não como realidade existindo em si, mas como fenômeno (FORGHIERI, 2009).

Forghieri (2009) explica que os pensamentos e as representações têm origem na vivência pré-reflexiva - vivência anterior a toda elaboração de conceitos e de juízos. Segundo a autora, até as mais abstratas e sofisticadas formulações científicas partem dessa vivência. A ciência não começa quando articula uma teoria, resultante de suas investigações, mas sim, com a intenção do cientista de esclarecer um problema que surgiu em sua vivência cotidiana. É no mundo da vida, no pré-reflexivo que o conhecimento começa a ser construído. 
Fica evidente que a Fenomenologia representa um método de acesso à realidade tal como ela é vivida por uma pessoa - uma realidade concreta do mundo (MACIEL, 2003). Ela pretende chegar ao fenômeno, tal como ele se manifesta para essa pessoa, em sua forma original, captado na experiência cotidiana imediata.

Nesse sentido, com o intuito de se aproximar da ótica do pesquisado, acessar seus significados, sem contaminá-los pelos próprios valores é que o pesquisador lança mão da Redução Fenomenológica.

É a Redução Fenomenológica que permite retornar ao mundo vivido, acessar o fenômeno que existe pelo fato de haver uma consciência intencional, uma consciência que atribui sentido a tudo que vivencia no mundo.

A Redução Fenomenológica consiste em retornar ao mundo da vida, que aparece antes de qualquer alteração produzida por sistemas filosóficos, teorias científicas ou preconceitos do sujeito. É um retornar à experiência vivida e refletir sobre ela, alcançando a essência do conhecimento ou o modo como este se constitui no próprio existir humano (FORGHIERI, 2009).

“É a ambição de igualar a reflexão à vida irrefletida da consciência” (MERLEAUPONTY ${ }^{5}$, 1971, p. 13 apud FORGHIERI, 2009, p. 22).

“A redução implica pôr em parênteses todos os julgamentos concernentes à existência do mundo, ou seja, implica a suspensão (epoché) de todo julgamento a propósito do mundo (O mundo não é pressuposto, nem negado, nem afirmado)” (SAPIENZA, 2007, p. 23-24).

Forghieri (2009) divide, para fins didáticos, a Redução Fenomenológica em dois momentos: envolvimento existencial e distanciamento reflexivo. No envolvimento existencial, o pesquisador deve abandonar a postura intelectual sobre seu objeto de estudo, deixar de lado os conhecimentos já adquiridos sobre a vivência estudada para então, conseguir abrir-se à vivência da pessoa pesquisada buscando uma compreensão global, intuitiva, espontânea e pré-reflexiva do modo de existir da pessoa que experiencia aquela vivência. Posteriormente, há o distanciamento reflexivo, em que o pesquisador estabelece uma distância crítica com o objetivo de ver a pessoa pesquisada como um ser distinto, visando também a refletir sobre sua compreensão e, a partir disso, tentar captar e descrever o significado da vivência, o que constitui a análise compreensiva do fenômeno. O distanciamento, porém, não pode ser completo, por ser necessário manter um elo com a vivência para que a enunciação descritiva seja o mais próximo possível da própria vivência. Vale destacar que, apesar desses

\footnotetext{
${ }^{5}$ MERLEAU-PONTY, M. Fenomenologia da percepção. São Paulo: Freitas Bastos, 1971.
} 
dois momentos serem descritos como separados com o intuito de facilitar a compreensão de cada um, na prática, ambos são inter-relacionados e conjugados, não chegando a haver uma completa separação entre eles.

Segundo Forghieri (2009), a redução é uma mudança de atitude - de natural para fenomenológica. A atitude natural é aquela que temos na vida cotidiana, em que não há reflexão e se ignora a existência da consciência como doadora de sentido a tudo que nos rodeia no mundo. Já a atitude fenomenológica propõe o retorno às coisas mesmas, ao fenômeno e olha a consciência como intencional, em que os objetos só existem para uma consciência doadora de sentidos.

A Redução Fenomenológica deve acontecer pelo fato de o homem encontrar-se intrinsecamente constituído com o mundo, sendo necessário que se distancie desse mundo para, então, poder compreendê-lo. Deve colocar em suspensão seus valores, seus pensamentos e suas teorias para ir ao encontro do mundo sem pré-julgamentos, buscando alcançar o conhecimento pré-reflexivo.

Através da redução fenomenológica é possível retomar o mundo da experiência original, retornar ao mundo-vida do entrevistado, desocultando o que salta aos olhos do pesquisador (LUYPEN, 1967).

Para que o pesquisador possa fazer uso deste recurso, é interessante que ele mesmo seja alvo de sua reflexão. Deve voltar-se para si e identificar, em sua trajetória, os significados e concepções das vivências que envolvem o tema que pretende estudar, realizando um mergulho em sua própria existência.

Com essa nova perspectiva, torna-se possível acessar um fenômeno dirigindo-se a ele da maneira como ele se mostra e não tomando como a priori valores e verdades como uma premissa ou hipótese. E é por isso, que o pesquisador somente se utiliza de recursos teóricos após a compreensão obtida pela observação, para evitar que se enquadre um indivíduo ou suas manifestações em determinada teoria, deixando de lado aspectos mais relevantes e mantendo o foco apenas no que é conveniente para tal visão teórica.

O olhar fenomenológico permite que o pesquisador vá além dos parâmetros da objetividade, dos determinismos, das certezas e verdades inquestionáveis e universais, da previsibilidade, tão presentes nos métodos da ciência tradicional.

Enquanto proposta de investigação imediata e descritiva dos fenômenos experienciados pela consciência, a fenomenologia descarta teorias a priori, explicações de natureza causal, pressupostos e hipóteses (VALLE, 1997). 
O olhar fenomenológico-existencial não visa a interpretar ou explicar o fenômeno, busca apenas compreendê-lo (FEIJOO, 2002).

Holanda (2003) define compreensão como uma coapreensão, uma tentativa de apreender a totalidade do fenômeno, sem que haja uma imposição conceitual. Para Martins (1984), compreender implica capacidade de transformar o que se mostra oculto, tornando-o explícito e transparente.

Segundo Garnica (1997, p. 111):

O homem compreende porque interroga as coisas com as quais convive. As coisas do mundo lhe são dadas à consciência que está, de modo atento, voltada para conhecê-las: o homem é já homem-no-mundo, ele percebe-se humano vivendo com outros humanos, numa relação da qual naturalmente faz parte, não podendo dissociar-se dela. Assim, não existirá neutralidade do pesquisador em relação à pesquisa - forma de descortinar o mundo, pois ele atribui significados, seleciona o que do mundo quer conhecer, interage com o conhecido e se dispõe a comunicá-lo. Também não haverá "conclusões", mas uma "construção de resultados", posto que compreensões, não sendo encarceráveis, nunca serão definitivas.

De acordo com Valle (2004), só é possível compreender o significado de um acontecimento para uma pessoa a partir de informações e observações oriundas dela própria; qualquer outra tentativa será feita a partir da perspectiva de quem está interpretando, podendo não convergir com a vivência de quem experiencia aquela situação.

Carvalho (1987, p. 35) pontua: “O revelar-se do cliente é a 'mostração' de sua totalidade e não de seus fragmentos”.

Bruns (2003, p. 72) explica que:

[...] não há um ser 'escondido', uma realidade 'em si mesma', objetiva e neutra atrás das aparências do fenômeno (uma vez que a intencionalidade da consciência permite as mais variadas perspectivas acerca do objeto).

Valle (1997) explica que o pesquisador com uma atitude fenomenológica não se assemelha a alguém que adota as Ciências Naturais como método em Psicologia, já que isto o afastaria do mundo de forma imparcial para descrevê-lo. Com a atitude fenomenológica, o pesquisador, ao mesmo tempo em que observa o mundo, relaciona-se com ele e com as pessoas com as quais busca investigar a experiência vivida.

Por fim, é importante ressaltar que a Fenomenologia possibilitou à Psicologia um novo posicionamento de inquirição dos fenômenos psicológicos, visando a interrogar as experiências vividas e os significados que os indivíduos lhes atribuem, centrando-se na 
relação sujeito-objeto-mundo, em vez de priorizar o objeto e/ou o sujeito, atendo-se apenas ao estudo dos comportamentos observáveis e controláveis (BRUNS, 2003).

\subsection{O ENFOQUe FenOMENOLÓGico DA PERSONALIDADE}

A psicóloga Yolanda Cintrão Forghieri (2009), a partir da contribuição de alguns fenomenólogos como Merleau-Ponty, Heidegger, Buber e Sartre e da influência de alguns psiquiatras fenomenólogos como Van den Berg, Medard Boss e Minkowski, elaborou um enfoque da personalidade apresentado em seu livro "Psicologia Fenomenológica: fundamentos, métodos e pesquisas”. Esse enfoque é baseado no que a autora conseguiu reunir de conciliável, de convergente entre as diferentes ideias propostas por esses representantes da Fenomenologia e é baseado na compreensão realizada por ela sobre seu existir e o existir de seus semelhantes.

De encontro com a visão fenomenológica sobre as possibilidades de conhecimento enquanto algo sempre inacabado, em contínua construção, pelo fato de homem e mundo também não serem estáticos, a autora apresenta sua proposta em relação ao enfoque fenomenológico da personalidade:

[...] não pretendo que as enunciações aqui reunidas e articuladas sejam tomadas como algo pronto ou finalizado e sim, como a 'estação' à qual cheguei, depois de uma longa 'viagem', na qual estou, ainda, prosseguindo. Meu intuito é de que as enunciações que aqui apresento não sejam consideradas como definitivas, mas como ponto de partida para novos envolvimentos e reflexões a respeito desse tema tão amplo e profundo que é a existência do ser humano (FORGHIERI, 2009, p. 24).

Com relação a esse Enfoque Fenomenológico da Personalidade, Forghieri (2009) descreve "personalidade" como o conjunto de características do existir humano, consideradas e descritas de acordo com o modo como são percebidas e compreendidas, pela pessoa, no decorrer da vivência cotidiana imediata.

O enfoque fenomenológico da personalidade proposto por Foghieri (2009) é composto pelas seguintes características básicas do existir humano: 1. Ser-no-mundo (Aspectos do mundo - mundo circundante, mundo humano e mundo próprio e as Maneiras de o homem existir nesse mundo - preocupada, sintonizada e racional); 2. Temporalizar; 3. Espacializar; 4. Escolher. Segundo a autora, tais características constituem uma totalidade, sendo que a 
organização em itens separados tem, apenas, o intuito de descrevê-las de modo minucioso para facilitar sua compreensão. A partir dessas características básicas do existir, Forghieri (2009) faz algumas considerações a respeito da Saúde e da Doença Existencial.

Esse enfoque fenomenológico da personalidade proposto por Forghieri (2009) orientará as reflexões fenomenológicas das entrevistas realizadas com os participantes deste estudo. Assim, optei por apresentar a parte teórica envolvendo as características básicas do existir humano, no capítulo 8 - Reflexões sobre o existir desses profissionais de saúde à luz da Psicologia Fenomenológica - por acreditar que poderá facilitar a compreensão dos leitores ainda não familiarizados com a proposta da autora bem como para tornar a leitura menos exaustiva e repetitiva.

\subsection{PROCEDIMENTOS METODOLÓGICOS}

\subsubsection{LOCAL}

O presente estudo foi realizado no Serviço de Oncologia Pediátrica do Departamento de Pediatria e Puericultura do Hospital das Clínicas da Faculdade de Medicina de Ribeirão Preto da Universidade de São Paulo (HCFMRP-USP).

O HCFMRP-USP é um hospital-escola de nível terciário de atenção, sendo referência para o atendimento de diversas especialidades. Além do foco em assistência e ensino, essa instituição hospitalar também se volta para pesquisas de diferentes áreas do saber.

Quanto ao serviço de Oncologia Pediátrica, ele foi criado no ano de 1983 e, atualmente, é composto por dois ambulatórios e uma unidade de internação. O Ambulatório de Oncologia Pediátrica funciona de segunda à sexta-feira, no período matutino; oferece atendimentos médicos e assistência realizada pelos profissionais de enfermagem, através de consultas e exames laboratoriais; assistência psicológica através de atendimentos individuais e grupais; acompanhamento nutricional, bem como assistência prestada pelos profissionais do Serviço Social. Já o Ambulatório de Hematologia Infantil funciona todas as sextas-feiras no período vespertino, sendo responsável pelo atendimento periódico de pacientes que já finalizaram o tratamento para o câncer, bem como pelo acompanhamento de pacientes portadores de outras doenças hematológicas. A unidade de internação está situada no sétimo 
andar deste hospital, no setor de Pediatria e Puericultura; esse espaço comporta a internação de um total de dez pacientes e dez respectivos acompanhantes, distribuídos em cinco quartos.

O serviço de Oncologia Pediátrica dessa instituição hospitalar está organizado para atender pacientes com diferentes hipóteses diagnósticas ligadas a doenças oncológicas, sendo que a assistência perpassa pela investigação diagnóstica, pelo tratamento e também pelo atendimento a pacientes que já finalizaram o tratamento.

A assistência é realizada por profissionais de diferentes áreas - médicos, enfermeiros, psicólogo, terapeuta ocupacional, nutricionistas e assistentes sociais, bem como por graduandos e residentes médicos; estagiários de psicologia, de nutrição e de terapia ocupacional.

Esses profissionais participam, semanalmente, de reuniões clínicas multidisciplinares, tanto na enfermaria como no ambulatório, com o objetivo de integrar saberes através de trocas entre profissionais de diferentes especialidades e também com o intuito de aperfeiçoar a assistência através de um cuidado integral e global dos pacientes atendidos. Além disso, são realizadas reuniões mensais na enfermaria visando a discutir questões administrativas e assistenciais.

Segundo dados da própria instituição, durante os meses de janeiro a dezembro de 2010 - período em que a coleta de dados desse estudo foi realizada - o serviço de Oncologia Pediátrica atendeu 219 pessoas de 0 a 19 anos, havendo ingresso de 141 novos casos no público já assistido (ARECO, 2011).

Especificamente, a respeito da assistência psicológica neste serviço, essa era composta, até o momento em que a coleta de dados foi realizada, por um psicólogo e quatro estagiários de graduação em Psicologia. A assistência psicológica é realizada de forma a acompanhar tanto o paciente como seu acompanhante desde o momento do pré-diagnóstico e permeando todo o período de tratamento - tanto nos retornos dos pacientes para consultas médicas em ambiente ambulatorial como em períodos de internações na enfermaria - além do atendimento a pacientes em cuidados paliativos e pacientes terminais, bem como oferecendo acompanhamento a pacientes que já terminaram o tratamento através do Plantão Psicológico realizado semanalmente, todas às sextas-feiras no período da tarde, no Ambulatório de Hematologia Infantil.

Neste cenário, o serviço de Psicologia realizava seu trabalho através de atendimentos individuais e atendimentos grupais. Os atendimentos grupais, voltados para a assistência a acompanhantes e pacientes, acontecem no mesmo dia e horário, mas em salas separadas, todas as sextas-feiras, no período da manhã, no Ambulatório de Oncologia Pediátrica. 


\subsubsection{PARTICIPANTES}

O Serviço de Oncologia Pediátrica é composto por profissionais de saúde de várias áreas de atuação. No momento em que a coleta de dados foi realizada, esse serviço contava com seis médicos, um psicólogo, uma terapeuta ocupacional, dois nutricionistas, dois assistentes sociais, dois enfermeiros, além de auxiliares de enfermagem, residentes e estagiários de diferentes áreas da saúde.

É preciso informar que a atuação de alguns desses profissionais dentro do HC restringe-se ao Serviço de Onco-Hematologia Pediátrica, como são os casos dos médicos docentes, de alguns médicos contratados, residentes de terceiro e quarto ano, bem como psicólogo e nutricionista responsáveis pelo atendimento ambulatorial que são contratados pelo Grupo de Apoio a Criança com Câncer (GACC), mas que atuam tanto na casa de apoio do GACC como no HC. Já outros profissionais prestam seus serviços não apenas ao serviço de Onco-Hematologia Pediátrica, mas atendem também às demais clínicas da Pediatria deste mesmo hospital, como são os casos da equipe de enfermagem composta por enfermeiros, técnicos e auxiliares de enfermagem, assistentes sociais, nutricionista responsável pela enfermaria, terapeuta ocupacional e os médicos residentes do segundo ano.

Vale ressaltar, ainda, que alguns desses profissionais atuam tanto em contexto ambulatorial como na enfermaria, como o psicólogo e os residentes do terceiro e quarto anos, enquanto outros se restringem a um único local como, por exemplo, há a equipe de enfermagem da parte ambulatorial e a equipe de enfermagem responsável pela parte da internação.

A partir dos objetivos do meu estudo, propus-me a mergulhar no mundo vivido dos membros regulares do Serviço de Oncologia Pediátrica com o intuito de acessar como percebem a experiência de cuidar de crianças e adolescentes com câncer que realizam tratamento neste Serviço.

Para desvelar esta experiência, foram realizadas entrevistas com alguns profissionais das diferentes especialidades que atuam dentro do Serviço de Oncologia Pediátrica, que tinham vínculo estável com a instituição, excluindo outros integrantes que prestavam uma colaboração eventual ou que realizavam estágio para aprimoramento profissional no Serviço.

Conforme mencionado anteriormente, o presente trabalho surgiu de minha inquietação a partir de minha atuação como estagiária de graduação e, posteriormente, como psicóloga voluntária junto ao Serviço de Oncologia Pediátrica do HCFMRP-USP. Logo, o meu contato 
inicial com a maioria dos profissionais não coincidiu com o momento concreto da pesquisa, mas já havia se estabelecido anteriormente, durante os dois anos em que atuei neste contexto.

O critério de escolha dos participantes foi intencional: optei por convidar aqueles profissionais de saúde com os quais tinha maior proximidade e liberdade, e que possuíam maior contato com o serviço, como por exemplo, a enfermeira-chefe responsável pelo atendimento na pediatria e um médico contratado, sendo um representante de cada categoria profissional, exceto com relação à assistência social, em que as duas profissionais colaboraram com o estudo.

A Tabela 1 apresenta uma caracterização dos profissionais que participaram da investigação, de acordo com idade, profissão, estado civil, tempo de formação profissional; experiência em Oncologia Pediátrica e carga horária de trabalho em Oncologia Pediátrica no HCFMRP-USP.

Tabela 1 - Caracterização dos participantes segundo idade, estado civil, profissão, tempo de formação, experiência na área de Oncologia Pediátrica e carga horária de trabalho em Oncologia Pediátrica junto ao HCFMRP-USP.

\begin{tabular}{ccccccc}
\hline Nome & Idade & $\begin{array}{c}\text { Estado } \\
\text { Civil }\end{array}$ & Profissão & $\begin{array}{c}\text { Tempo de } \\
\text { Formação } \\
\text { Profissional }\end{array}$ & $\begin{array}{c}\text { Experiência } \\
\text { em Oncologia } \\
\text { Pediátrica }\end{array}$ & $\begin{array}{c}\text { Carga Horária em } \\
\text { Oncologia Pediátrica } \\
\text { no HCFMRP-USP. }\end{array}$ \\
\hline Eduarda & 31 anos & Casada & Enfermeira & 10 anos & 9 anos & 30 horas/ semana \\
\hline Clara & 50 anos & Casada & $\begin{array}{c}\text { Assistente de } \\
\text { enfermagem }\end{array}$ & 32 anos & 32 anos & 30 horas/semana \\
\hline Denise & 32 anos & Casada & Nutricionista & 7 anos & $\begin{array}{c}2 \text { anos e } \\
6 \text { meses }\end{array}$ & 40 horas/semana \\
\hline Ana & 24 anos & Solteira & $\begin{array}{c}\text { Terapeuta } \\
\text { Ocupacional }\end{array}$ & $\begin{array}{c}1 \text { ano e } \\
6 \text { meses }\end{array}$ & $\begin{array}{c}1 \text { ano e } \\
3 \text { meses }\end{array}$ & 30 horas/semana \\
\hline Tadeu & 25 anos & Solteiro & $\begin{array}{c}\text { Psicólogo } \\
2 \text { anos e } \\
6 \text { meses }\end{array}$ & 5 anos & 20 horas/semana \\
\hline Júlio & 53 anos & Casado & Médico & 30 anos & 27 anos & 20 horas/semana \\
\hline Regina & 54 anos & Casada & $\begin{array}{c}\text { Assistente } \\
\text { Social }\end{array}$ & 30 anos & 21 anos & 40 horas/semana \\
\hline Natália & 41 anos & Casada & $\begin{array}{c}\text { Assistente } \\
\text { Social }\end{array}$ & 18 anos & 11 anos & 30 horas/semana \\
\hline
\end{tabular}

\footnotetext{
${ }^{6}$ Todos os nomes aqui mencionados são fictícios para preservar a identidade dos participantes.
} 


\subsubsection{ASPECTOS ÉTICOS}

Para a realização deste estudo foram tomados cuidados orientados por princípios éticos em pesquisa, buscando oferecer condições adequadas de proteção às pessoas participantes bem como à instituição à qual pertencem.

Inicialmente, informei em uma reunião composta por profissionais atuantes no Serviço de Oncologia Pediátrica do Departamento de Pediatria e Puericultura do HCFMRP-USP sobre a intenção de realizar esse estudo. Essa colocação teve como intuito esclarecer a proposta, a perspectiva teórico-metodológica a ser utilizada e os objetivos do trabalho.

De uma forma geral, houve manifestações de concordância por parte dos profissionais, reconhecendo a viabilidade e as possíveis contribuições dessa investigação. Uma pequena parcela dos membros da equipe demonstrou certa resistência à minha proposta, alegando que outros estudos já haviam sido ali realizados por diferentes profissionais de saúde e não ofereceram contribuições concretas para o serviço.

Inicialmente, minha postura foi a de mostrar a contribuição inicial que esse estudo poderia oferecer, que é, por si só, permitir conhecer melhor o serviço e me aproximar das demandas dos profissionais que nele atuam para, então, avaliar se existe necessidade de implementar algum cuidado a esses profissionais de saúde e, caso a resposta fosse afirmativa, pensar quais seriam as estratégias adequadas e viáveis a este contexto.

Na minha visão, a resistência de alguns integrantes da equipe ao desenvolvimento deste trabalho pode estar relacionada a vários fatores: crença de que ninguém mais do que eles próprios conhecem seu trabalho e os requisitos necessários para desempenhá-lo descartando, dessa maneira, qualquer tipo de proposta ofertada, bem como um receio de que os resultados obtidos neste estudo trariam à tona as imperfeições e lacunas do serviço com relação à própria atuação desses profissionais, o que pressupõe o reconhecimento dos limites da administração, dos limites pessoais e da necessidade de mudanças. Vale destacar que a existência de limites não significa, do meu ponto de vista, que o serviço seja de baixa qualidade ou que não ofereça uma adequada assistência aos pacientes, mas sim, que se pode realizar avanços. Além disso, são comuns manifestações de resistência à mudança, ao novo, pelo fato de o indivíduo ter que lidar com aspectos desconhecidos e, portanto, desafiadores, que rompem com seu estado atual de equilíbrio; essa postura é comum mesmo quando o equilíbrio não equivale a vivências de situações agradáveis. 
Mas, mais importante que tudo isso, penso que as dúvidas quanto à relevância deste trabalho ressaltam a própria impotência desses profissionais diante de tantos aspectos velados, encobertos e desconhecidos, bem como a importância que os mesmos atribuem à necessidade de cuidar dessas questões e transformar alguns aspectos da própria assistência por eles prestada e do contato com os colegas. Pode haver uma dificuldade em acreditar que é possível fazer diferente, promovendo cuidado aos cuidadores...

Apesar dessas manifestações, a concordância da grande parte dos profissionais que compõem a equipe do Serviço de Oncologia Pediátrica permitiu-me encaminhar meu projeto ao Comitê de Ética em Pesquisa do HCFMRP-USP para a avaliação, adotando os procedimentos éticos de respeito aos voluntários e à instituição, de acordo com a resolução $\mathrm{n}^{\circ}$ 196/96 sobre pesquisas envolvendo seres humanos (BRASIL, 1996).

Após a aprovação do projeto (ANEXO A), realizei contato individualizado com os profissionais visando a esclarecer os objetivos deste estudo, assim como a reafirmar as condições de sigilo profissional para cada participante, apresentando-lhes o Termo de Consentimento Livre e Esclarecido (APÊNDICE A).

Ressalto que somente foram considerados colaboradores aqueles que concordaram livremente em participar do trabalho, manifestando estarem de acordo com suas condições expostas no termo referido. Além disso, foi explicitado que a recusa de participação no trabalho não traria nenhum prejuízo aos profissionais de saúde.

É importante mencionar que todos os profissionais convidados a colaborar com o estudo demonstraram disponibilidade e interesse, não havendo qualquer manifestação de resistência ou recusa.

Cabe ressaltar, também, que os nomes atribuídos a esses profissionais são fictícios, visando a preservar suas verdadeiras identidades. Após o término de cada uma das entrevistas, discuti com cada um dos colaboradores sobre a questão do sigilo e da privacidade, já que alguns deles mencionaram aspectos de suas trajetórias pessoais que poderiam facilitar sua identificação. Mostrei-me disposta a omitir tais questões, caso os participantes assim desejassem, porém, nenhum deles solicitou que dados fossem omitidos. 


\subsubsection{RECURSO BÁSICO DE ACESSO AO SER}

Para viabilizar o "mergulho" nas vivências desses profissionais e acessar os significados que eles atribuem à experiência de cuidar de crianças e adolescentes com câncer, utilizei a entrevista de caráter aberto, por ser um recurso metodológico que permite obter descrições de experiências vividas.

A busca de sentidos atribuídos pelos profissionais à arte de cuidar de crianças e adolescentes com câncer justifica-se pelo fato de que as situações vivenciadas pelos indivíduos não possuem um significado em si mesmas, adquirindo sentido para quem as experiencia, dependendo da maneira de existir de cada um.

Os depoimentos ou relatos escritos da vivência estudada são considerados os dados empíricos das pesquisas fenomenológicas, já que se trata do aspecto visível da experiência vivenciada (ALVES, 2003).

A postura fenomenológica na realização de entrevistas visa à compreensão do conteúdo trazido pelo entrevistado, e não à interpretação ou à explicação. Nesse sentido, o entrevistador mergulha no mundo do outro, acompanhando seu ritmo existencial, aproximando-se de seus significados e oferecendo um espaço para que o entrevistado se sinta livre para expressar-se em sua singularidade.

A entrevista é realizada sob a forma de existência situada no encontro. Envolve entrar em contato com a alteridade do outro, que possui uma realidade distinta da realidade do pesquisador, necessitando que este descentre de si para conseguir ter uma compreensão empática do entrevistado (CAPALBO, 1987).

Martins e Bicudo (2005) ressaltam que o acesso às qualidades essenciais do fenômeno não se dá através da rígida reprodução de procedimentos preestabelecidos pela ciência, considerados corretos e compatíveis com o desenvolvimento científico. Na pesquisa fenomenológica, a situação de pesquisa não é definida previamente pelo pesquisador, mas pelo encontro com os participantes.

Para Valle (2004), ao entrevistar uma pessoa deve-se buscar perceber sua posição frente ao mundo, sua historicidade, reconhecendo-a em sua singularidade e originalidade. Esses encontros funcionam não só como um momento de coleta de dados mas, também, de acolhimento, apoio, expressão e construção de significados.

O pesquisador atua como facilitador para o acesso do sujeito ao vivido. Muitas vezes, o colaborador da pesquisa pode nunca ter dividido sua experiência, sendo esse encontro uma 
oportunidade não só de dizer, mas também de acessar esse vivido, já que o vivido não necessariamente é “sabido” de antemão (AMATUZZI, 2003).

Para Holanda (2003, p. 50-51),

Falar a respeito de uma experiência, uma vivência acerca de determinado fenômeno, significa a possibilidade de explorar, sob a ótica do respondente, toda a gama de sentidos dispostos em tal vivência. Implica, ainda, a possibilidade de se alcançar um horizonte de perspectivas diversas, únicas, factíveis, para aquele sujeito-vivente, a partir de sua própria vivência. Isto significa que não se explora uma determinação a priori, mas um resgate de significações que somente o sujeito em questão pode estabelecer.

Carvalho (1987) relata que a fala, na entrevista fenomenológica, é um veículo de significações que possibilita ao participante entrar em contato com sua maneira de estar no mundo e de se posicionar frente às situações, pois o indivíduo que fala para outro está, ao mesmo tempo, falando também para si. Trata-se de uma oportunidade de "se fazer ver”, um movimento de se perceber e é esse desvelar que abre portas para ressignificar, recriar experiências vividas, reconhecer necessidades e possibilidades.

A pesquisa fenomenológica está dirigida para significados, ou seja, para expressões claras sobre as percepções que o sujeito tem daquilo que está sendo pesquisado. Os dados só existem enquanto resultado de significados atribuídos a partir da tematização do sujeito sobre o evento, logo, o pesquisador não se preocupa com fatos, mas com o que os eventos significam para o participante. Ao contrário, os pesquisadores que realizam pesquisas a partir da perspectiva das Ciências Naturais concebem os fatos como independentes da consciência que os sujeitos possam ter dele. (MARTINS; BICUDO, 2005).

No contato com os entrevistados, o pesquisador que realiza a pesquisa fenomenológica busca descrições precisas da experiência vivida pelos participantes para, a partir delas, indagar os princípios gerais segundo os quais tais sujeitos organizam suas experiências na vida cotidiana. Através dessas descrições, o pesquisador acessa a concretude do mundo-vida dos entrevistados, a essência do fenômeno investigado. As descrições são indícios de como o sujeito percebe o fenômeno (GARNICA, 1997; ROSSI, 2006).

A linguagem é um recurso básico que permite a compreensão de determinadas situações que o pesquisador deseja investigar, possibilitando-lhe adentrar ao mundo próprio, particular do sujeito, através do veículo de expressão de sua realidade singular - a fala (VALLE, 1997). 
O discurso vem embutido de gestos, tons, silêncios, que facilitam a compreensão do entrevistado, pois revelam o seu modo de estar no mundo. De acordo com Carvalho (1987, p. 19), “[...] o corpo enquanto lugar de ‘fazer ver', também ‘fala’ e também ‘se mostra””.

É importante que o entrevistador seja um ouvinte ativo, que esteja atento não só ao que é dito, mas também aos gestos e aos silêncios que perpassam cada encontro existencial, para que possa haver uma real compreensão das vivências do participante. Além disso, deve ter disponibilidade suficiente de escuta para oferecer espaço para que o participante expresse, à sua maneira, seus pensamentos e sentimentos.

Com relação ao silêncio, é importante que o entrevistador tenha disponibilidade interna para tolerá-lo, já que ele permite uma imersão do indivíduo em seu próprio ser, possibilitando reflexão, elaboração, além de facilitar a própria compreensão.

Valle (1997) alerta para a necessidade de uma relação engajada entre pesquisador e participante, uma relação permeada por coexistência, encontro, intersubjetividade, diálogo, empatia e liberdade pessoal.

Amatuzzi (2001) define a pesquisa fenomenológica como participante, ativa e interativa. Reconhecer a presença do pesquisador como subjetividade em sua pesquisa permite um coexistir empático e engajado com o depoente, possibilitando ao pesquisador aproximar-se do mundo vivido do sujeito com espontaneidade e naturalidade (VALLE, 1997).

Holanda (2003) ressalta que, na pesquisa fenomenológica, o pesquisador não prescinde de sua participação no ato de pesquisar, coparticipando junto ao sujeito vivencial, à sua semelhança, enquanto um sujeito também intencional.

Assim, não ignorei minha história prévia de relacionamento com esses profissionais de saúde que colaboraram neste estudo, como também não assumi uma postura neutra ou distante diante do encontro com esses colaboradores e da posterior análise de seus discursos.

\subsubsection{OBTENÇÃO DOS DEPOIMENTOS}

Para acessar o fenômeno interrogado, inserido na experiência de vida dos profissionais de saúde em questão, como já foi dito anteriormente, elegi a entrevista como forma de acessar os significados por eles atribuídos à experiência de cuidarem de crianças e adolescentes com câncer. 
A entrevista foi constituída pela questão norteadora: "Como você vivencia o cuidar de crianças e adolescentes com câncer na sua prática profissional?”.

Garnica (1997) ressalta que os fenômenos nunca são compreendidos sem que sejam inicialmente interrogados.

O entrevistador, porém, pode ir além da questão norteadora, e fazer interrogações, buscar ampliações e confirmações do fenômeno descrito pelo entrevistado desde que essas intervenções tenham origem naquilo que está sendo trazido pelo próprio entrevistado (CARVALHO, 1987; FIORINI, 1989).

Na pesquisa fenomenológica, o pesquisador, inicialmente, está preocupado com a natureza do que vai investigar, de tal forma que não existe para ele nenhum princípio explicativo, teorias, compreensão prévia ou qualquer indicação definidora do fenômeno. O trabalho é iniciado com a interrogação do fenômeno, o que quer dizer que o pesquisador não conhece as características essenciais do fenômeno que pretende estudar (MARTINS; BICUDO, 2005).

Em um estudo fenomenológico, o número de entrevistas realizadas deve estar diretamente relacionado ao desvelamento do fenômeno aos olhos do pesquisador, ou seja, a coleta de dados e a análise das entrevistas devem prosseguir até que for percebido que os pontos trazidos pelos entrevistados se coadunam ou se distanciam, possibilitando que as convergências e divergências já se façam presentes ao longo da trajetória das entrevistas, sendo observada a manifestação do que é essencial.

Segundo Bruns e Trindade (2003), o número de entrevistas depende do que se obteve em cada uma delas e se, ao longo da realização do estudo, chegou-se a vislumbrar aspectos que se repetem nas falas, alcançando uma descrição suficiente do fenômeno.

Com esse objetivo, realizei o contato pessoal com alguns integrantes do Serviço apresentando os objetivos e as condições de realização do estudo. Uma vez que os profissionais aceitaram colaborar com a realização deste, agendamos horário e local adequados para a realização da entrevista.

A fase de obtenção dos depoimentos realizou-se no período de julho a dezembro de 2010. As entrevistas ocorreram em três locais distintos, conforme escolhas realizadas pelos próprios profissionais: no hospital, na Casa de Apoio do GACC e em consultório particular.

Foi, então, realizada uma entrevista aberta, em um único encontro, em uma sala reservada, com cada um dos colaboradores individualmente.

As entrevistas foram iniciadas com a questão norteadora mencionada anteriormente, sendo todas elas audiogravadas com o consentimento dos participantes. O objetivo de 
audiogravar atendeu à necessidade de garantir uma fiel apreensão dos depoimentos pelo pesquisador no momento de transcrevê-los.

Durante as entrevistas, alguns apontamentos e intervenções foram feitos, visando a permitir clareza e fluidez aos depoimentos. Além disso, frente à mobilização de alguns participantes, demonstrada pelo choro ou pelos olhos marejados, fiz algumas intervenções no sentido de acolher essas manifestações e ressaltar a possibilidade de interrupção da entrevista, caso o participante assim desejasse, o que não ocorreu.

Amatuzzi (2003) esclarece que, em alguns momentos, a pesquisa e a intervenção não podem ser dissociadas, pois a entrevista apresenta-se para o participante como mobilizadora do acesso ao vivido para além do já-dito, além de mostrar-se como propiciadora de transformação e desenvolvimento individual.

Seguindo orientações de Rossi (2006), após o término de cada entrevista, busquei o máximo de proximidade de tempo entre a entrevista e a transcrição, visando a resgatar na memória o que o gravador não registra: a imediaticidade da relação intersubjetiva entre pesquisador e colaborador, que é acessível apenas à percepção e à intuição do próprio pesquisador.

As entrevistas realizadas tiveram durações variadas - a mais breve durou 12 minutos e a mais longa, 44 minutos, sendo 28 minutos a duração média das mesmas. Mas vale ressaltar que, independentemente da duração cronológica das entrevistas, cada uma delas foi encerrada no momento em que percebi que aquele depoimento estava se mostrando suficientemente revelador dos significados que o depoente atribuía ao fenômeno em estudo.

\subsubsection{Proposta de AnÁlise fenomenológica dos Depoimentos: "ModAlidade do FENÔMENO SITUADO”}

Para realizar a análise das entrevistas obtidas neste estudo foram utilizados os referenciais de Giorgi (1985), Martins e Bicudo (2005) e Valle (1997) que sugerem os seguintes passos para acessar a "estrutura do fenômeno situado", uma vertente da pesquisa qualitativa enraizada na Fenomenologia:

1) Apreensão do sentido do todo: o pesquisador realiza, de forma atenta,uma leitura global de todos os depoimentos, sem adotar uma postura interpretativa, mas com o intuito de 
efetuar uma aproximação à linguagem de cada participante, colocando-se no lugar do mesmo e também visando a uma apreensão do significado da entrevista como um todo.

2) Discriminação das unidades de significado: releitura dos depoimentos, quantas vezes for preciso, para entrar em contato com o fenômeno interrogado de acordo com a vivência de cada um dos entrevistados. Isso permite trazer à tona, aos olhos do pesquisador, as "unidades de significados" - trechos imbuídos de sentidos atribuídos à vivência em questão. As unidades de significado não existem por si mesmas, sendo o pesquisador que, com sua visão de mundo e abertura ao outro, as percebe segundo o que foi proposto pela questão norteadora. Logo, não se trata de uma tarefa rígida, pois é possível que diferentes pesquisadores indiquem diferentes significados, de acordo com suas interrogações e perspectivas.

3) Transformações das expressões cotidianas do sujeito em linguagem psicológica: após a identificação das unidades de significado, o pesquisador busca expressar o "insight” psicológico nelas contido. Trata-se de uma transformação da linguagem do entrevistado no discurso psicológico para que o pesquisador possa trazer à tona realidades múltiplas ocultadas na fala dos participantes.

4) Busca das convergências e divergências entre as unidades de significado: o pesquisador localiza nas descrições os temas repetidos, aqueles que convergem em seu sentido, alcançando assim o invariante, a essência, a estrutura do fenômeno estudado.

5) Síntese das unidades de significado transformadas em proposição: na última etapa, cabe ao pesquisador sintetizar todas as unidades de significado em uma proposição consistente a respeito de como o sujeito vivencia o fenômeno em estudo, possibilitando uma análise compreensiva da estrutura de experiência das pessoas. Nessas sínteses, todas as unidades de significados transformadas são levadas em conta: todas elas devem estar, pelo menos, implicitamente, contidas nessa descrição.

É importante mencionar que os cinco momentos descritos anteriormente não são estanques ou desconectados, mas inter-relacionados.

O pesquisador que trabalha numa perspectiva fenomenológica orienta-se por um sentido, isto é, pelo conhecimento imediato, intuitivo, lógico que tem do fenômeno a ser investigado. Além disso, também utiliza critérios científicos, assim como procede o pesquisador que adota os princípios das Ciências Naturais. Porém, diferentemente do cientista natural, o fenomenólogo ainda está engatinhando com relação à produção de uma metodologia “científica” nas ciências humanas e, por isso, não possui paradigmas prontos que dão origem a métodos a serem usados, prontos-a-mão (MARTINS; BICUDO, 2005). 
É importante ressaltar que a análise de dados tem início assim que o pesquisador se encontra com o pesquisado, ocasião em que, juntos, pensarão a experiência e falarão sobre o vivido (AMARAL, 2002).

Forghieri (2009) explica que, no momento do encontro, o pesquisador-facilitador mostra um envolvimento com os participantes e uma aproximação intuitiva, enquanto que, no momento da análise, é necessário um distanciamento crítico que possibilita reflexão e elaboração racional do pesquisador.

Para Machado (1994), o pesquisador, ao analisar uma descrição, despoja-se de seu referencial teórico paradigmático, mas não exclui o seu pensar e a sua postura prévia, já que se encontra necessariamente orientado pela compreensão pré-reflexiva do que ali vai encontrar.

Embora o método fenomenológico proponha o uso da Redução Fenomenológica, não é possível que consigamos abstrair plenamente todas as nossas pré-concepções, até mesmo porque não é objetivo último da Fenomenologia a neutralidade e o distanciamento total do pesquisador. 


\section{APRESENTAÇÃO E COMPREENSÃO DOS DISCURSOS}

Neste capítulo busco trazer à tona uma descrição do fenômeno "ser-profissionalatuante-em-Oncologia-Pediátrica”. Essa descrição foi possibilitada pelo encontro da minha subjetividade com cada uma das subjetividades dos participantes deste estudo, ao conduzir as entrevistas individuais, ao ler as transcrições das mesmas e ao realizar a Redução Fenomenológica $^{7}$. Posteriormente, busquei aproximar-me das convergências e divergências que, através de minha própria subjetividade, pude encontrar nos discursos dos participantes.

Amatuzzi (2003) alerta que é preciso considerar que nossas palavras ou visões podem estar mais ou menos próximas do vivido puro, já que sofrem interferências de hábitos, de pressões sociais e de autoconceito. Além disso, são influenciadas também pela cultura e pela época histórica em que vivemos, o que determina o que buscamos, o que temos acesso e interfere na forma como vemos ou contamos um fato.

As categorias temáticas que emergiram desse processo foram: Adentrando em um contexto de atuação peculiar: especificidades do cuidado em Oncologia Pediátrica; A essência do cuidar em Oncologia Pediátrica: significados; Tocar o outro e ser tocado por ele: uma relação de cuidado permeada por desafios e realizações; Atuação em equipe: importância e desafios; Cuidando de quem cuida: estratégias para lidar com a dor do ofício.

\subsection{ADENTRANDO EM UM CONTEXTO DE ATUAÇÃO PECULIAR: ESPECIFICIDADES DO CUIDADO EM} ONCOLOGIA PEDIÁtRICA

Ao abordar suas vivências em Oncologia Pediátrica, o médico Júlio relembrou que sua inserção neste contexto de atuação não foi marcada por sonhos ou planejamentos. Ele explicou que, durante a graduação, estava inclinado a escolher fazer residência em Cardiologia, porém um professor da Hematologia Clínica o influenciou a fazer residência em Hematologia. O fato de ter repensado sua decisão inicial revela a abertura desse profissional para conhecer outra especialidade, mas evidencia também que, além de se abrir para outra

\footnotetext{
${ }^{7}$ A Redução Fenomenológica foi explicitada no capítulo 5 - Trajetória Metodológica: um caminho para a compreensão do fenômeno - no item 5.2 - Método Fenomenológico.
} 
possibilidade, o médico permitiu-se encantar pela mesma, sentimento esse que direcionou suas escolhas posteriores.

Sempre gostei de clínica [...] Fiz Clínica, não sou Pediatra, mas ia fazer Cardiologia [...] E um professor, já meu amigo: 'Não, você vai fazer 'Hemato'... e eu 'Não, que fazer 'Hemato'! Vou fazer Cardiologia!'. Mas ele, espertamente... [...] me levava para laboratório; falava: 'Vem cá, vamos conhecer! Vamos ver umas lâminas' [...] Quando entrei no R1 [Primeiro ano de Residência Médica] de clínica, né... tem que fazer um ano de clínica geral [...] eu já estava decidido pela 'Hemato' [risos] (Júlio, médico).

Especificamente, a respeito da atuação em Oncologia Pediátrica, o médico Júlio contou que essa aproximação também não foi planejada ou sonhada: quando ainda era residente no HCFMRP-USP, auxiliava o chefe da Oncologia Pediátrica na parte hematológica do tratamento infantil e, após término da residência, foi convidado por ele para continuar no HC. Esse convite foi inicialmente recusado mas, quatro anos depois, quando novamente foi convidado, aceitou prestar o concurso, ingressando neste hospital como médico contratado.

Naquela época, a 'Hemato' Infantil era muito dependente da 'Hemato' Clínica [...] O [chefe da Oncologia Pediátrica] era sozinho [...] ele não tinha muita experiência com a parte laboratorial e mesmo com o componente de condutas [...] Como eu lidava bem com ele, comecei a levá-lo para o laboratório [...] Então, a gente ia para o laboratório e ele me levava na enfermaria também (Júlio, médico).

[...] fazia diagnóstico pro [chefe da Oncologia Pediátrica]. [...] E aí, comecei a ver as crianças, gostava e tal. [...] o chefe da Oncologia Pediátrica [...] me falou pra trabalhar com ele, mas falei pra ele que eu ia para cidade e aí, eu vim pra cá [consultório] em 83. [...] Em 87, eu estava atendendo aqui, e [...] de repente, entra ele [chefe da Oncologia Pediátrica]. [...] Ele falou: 'consegui uma vaga e queria que você fosse trabalhar comigo. Na 'Hemato', você é muito bom e eu cuido da 'Onco' Pediátrica, dos outros tumores'. [...] Aí, me preparei e [...] passei no concurso (Júlio, médico).

As coisas foram acontecendo não planejadas, nunca foi... primeiro fazer hematologia, depois fazer 'Hemato-Pediatria', depois voltar lá [HC] (Júlio, médico).

Diferentemente da situação do médico Júlio, a terapeuta ocupacional Ana e o psicólogo Tadeu comentaram que o início da atuação em Oncologia Pediátrica foi marcado por escolhas que começaram a ser feitas ainda no período da graduação.

[...] eu quis realmente a 'Onco'; fiz estágio [na graduação], depois fiquei ali de voluntária esperando mesmo que abrisse concurso porque, realmente, queria trabalhar ali, especialmente na 'Onco' (Ana, terapeuta ocupacional). 
Eu comecei a atuação em Oncologia Pediátrica dentro da graduação. Eu me lembro de uma aula que tive quando estava no quarto ano com o psicólogo contratado da Oncologia Pediátrica [...] E eu fiquei... 'Nossa, psicólogo trabalha em pediatria?!'. Eu nunca tinha me tocado disso! E então, por uma questão de escolha de estágios, de combinação de possibilidades... de juntar Oncologia com hospital, com crianças, que era algo que eu não tinha trabalhado ainda, era, então, o estágio de Oncologia Pediátrica e por essas razões eu fui fechando a escolha (Tadeu, psicólogo).

O fato de ter escolhido trabalhar neste contexto não excluiu os desafios vivenciados pelo psicólogo Tadeu, entre eles: o contato com um contexto desconhecido e as próprias exigências para conseguir aproveitar todas as oportunidades que o estágio poderia proporcionar para sua profissionalização como psicólogo.

Começar aquilo foi muito desafiador para mim, porque era minha formação como psicólogo, era minha formação como psicólogo hospitalar, né... e era a minha formação em Psico-Oncologia. Então, eu estava nessa intersecção de coisas (Tadeu, psicólogo).

A assistente social Regina contou que, apesar de ter escolhido trabalhar em um contexto hospitalar, foi surpreendida quando sua contratação se destinou ao setor de Oncologia Pediátrica. Relembrou o quanto os três primeiros meses foram difíceis pelo contato com o desconhecido, por não saber como ela lidaria com o novo trabalho. Apesar de relatar não ter experimentado sentimentos de falta de capacidade para desempenhar atividades ligadas à prática da assistência social, temia não conseguir mobilizar recursos suficientes para realizar suas funções, por sentir-se “tocada” pelas dores das mães dos pacientes que dividiam seus sofrimentos com ela. Devido a essa sensibilidade e empatia para com as mães dos pacientes, bem como pelo desconforto que sentia ao pensar nos procedimentos invasivos realizados para o tratamento das crianças e adolescentes, Regina contou que, por muitas vezes, pensou em desistir.

[...] quando passei no concurso e fiquei sabendo que era para trabalhar na área de 'Oncopediatria', tive muitas dúvidas em aceitar ou não vir trabalhar no hospital. [...] Me questionei muito: 'Será que vou dar conta?', 'Como que vai ser?' Nunca tive experiência, tinha as filhas pequenas, tinha um monte de dúvidas (Regina, assistente social).

Os três primeiros meses foram muito difíceis... enquanto pessoa, enquanto profissional... medo de não dar conta, medo de não me adaptar nessa área! Cheguei a pensar em desistir! (Regina, assistente social).

A dificuldade maior foi por se tratar de câncer. Eu não tinha, assim, a ideia... a gente sabe o que é câncer, mas os problemas que ele traz, como é conviver com crianças e adolescentes com câncer, qual é o sofrimento que essa 
criança, esse adolescente, a família passam... Achei que não ia dar conta, não ia dar conta de ver esse sofrimento, porque você vivencia, presencia... tem momentos muito dolorosos! Não que eu não ia dar conta de encaminhar para resolver um problema social, porque isso é a parte técnica da área. [...] o hospital, por ser grande, não me assustou. O que me assustou foi a doença e os procedimentos invasivos que as crianças têm que fazer (Regina, assistente social).

Falei: 'será que vou dar conta de estar junto, estar resolvendo?' [...] porque você está presenciando o sofrimento ali e a mãe sofre por ver o filho sofrendo e, por outro lado, as mães sabem que os filhos têm que passar por todos esses procedimentos. Muitas mães falam: 'Meu Deus, será que é isso que tem que ser feito? Será que meu filho tem que passar por isso?’ [...] Meu medo, de início, era de não dar conta e você tem que estar preparada para falar para mãe: 'Mãe, existe todo esse sofrimento, mas é para o bem de seu filho’ (Regina, assistente social).

A enfermeira Eduarda também revelou ter enfrentado momentos de questionamentos em relação à sua escolha profissional, pelo fato de entrar em contato com situações intensas de sofrimento. Ela enfatizou que essas circunstâncias ocorreram ao longo de sua trajetória profissional e não só no início do trabalho em Oncologia Pediátrica, mas sente que, apesar dessas dificuldades, fez e faz sentido enfrentá-las. Logo, ela demonstrou continuar escolhendo atuar nesse contexto a despeito dos obstáculos.

[...] já tive situações em que encostei na parede e falei: 'Meu Deus, o que escolhi para mim! Será que devo continuar na profissão?'. Porque há tanto sofrimento dos pais, principalmente em ocasiões em que ocorre a morte! Mas, você respira fundo e fala: "Não, a gente vai conseguir enfrentar, embora tenham todas essas dificuldades”! (Eduarda, enfermeira).

Pelo fato de alguns participantes trabalharem em outros setores do HC, além da Oncologia Pediátrica - a enfermeira, a assistente de enfermagem, a nutricionista, a terapeuta ocupacional e as duas assistentes sociais atuam na Pediatria como um todo e o médico trabalha também na Hematologia Clínica - eles estabeleceram comparações entre a atuação em Oncologia Pediátrica e a atuação em outras clínicas e revelaram especificidades do trabalho em Oncologia Pediátrica, segundo seus olhares.

O médico Júlio, a terapeuta ocupacional Ana e a assistente de enfermagem Clara revelaram experimentar um sabor especial pela atuação em Oncologia Pediátrica.

[...] é especial! É diferente de você tratar uma anemia (Júlio, médico).

[...] queria trabalhar ali [Setor de Onco-Hematologia Pediátrica]... especialmente na 'Onco'... na Pediatria toda, mas especialmente ali, que é isso que eu gosto, que é isso a que me dedico mesmo [...] Então, é um lugar 
que me sinto bem trabalhando, é onde gosto de estar (Ana, terapeuta ocupacional).

De todas as especialidades, a que eu mais gosto de trabalhar é em Oncologia [...] Eu gosto demais de mexer com Oncologia! [...] tenho um carinho especial por eles [crianças e adolescentes com câncer]! (Clara, assistente de enfermagem).

Para a assistente de enfermagem Clara, a dor e o sofrimento vivenciados pelas crianças e adolescentes com câncer despertam mudanças favoráveis ao desenvolvimento dos mesmos, gerando um amadurecimento, que não seria vivido caso o adoecimento não estivesse acontecido. Clara acredita que, justamente pelo sofrimento vivenciado, esses pacientes necessitam de mais atenção e cuidado.

[...] sempre gostei de trabalhar com crianças oncológicas porque acho que elas são especiais, assim... são crianças mais sofridas, que amadurecem mais cedo, então, elas são diferentes [...] Com eles, você precisa ter mais atenção, mais carinho e são umas crianças que... assim... sofridas, porque é um tratamento muito sofrido (Clara, assistente de enfermagem).

A nutricionista Denise revelou desenvolver um envolvimento mais profundo com pacientes com câncer tanto pela doença que os acomete como por perceber que seu trabalho é mais reconhecido por essa clínica.

[...] sinto que tenho mais envolvimento com essas crianças, mas não sei dizer se é porque essas crianças são da 'Onco'. [Silêncio] Talvez sim. Acho que é um conjunto de coisas, porque acho que também por ter meu trabalho mais valorizado lá, parece que eu quero fazer mais, corresponder mais... fazer mais a diferença! (Denise, nutricionista).

É possível pensarmos que, devido aos estigmas associados ao câncer, essa doença alcance uma visibilidade social e cultural que pode ser responsável por despertar em alguns profissionais o desejo de ampliar o cuidado que dedicam aos pacientes com câncer.

Apesar disso, a enfermeira Eduarda e a assistente social Natália acreditam que não há diferenças no cuidado prestado por elas nas diferentes clínicas pediátricas.

[...] para mim, não teria diferença em cuidar da criança, vendo a criança em si... Mas, a sociedade ainda vê o câncer com muito mais temor do que qualquer outra doença (Eduarda, enfermeira).

[...] percebo que trabalho de forma igual, assim... [...] no meu trabalho em si, percebo que não há tantas diferenças [...] a diferença mesmo é [...] a forma com que o câncer é visto e isso assusta bastante [as pessoas em geral]! [...] O câncer ainda tem aquele mito de uma doença que é fatal, né [...] [as famílias] 
falam: 'Ainda bem que não é um câncer. Aí, eu fiquei com tanto medo!'. Isso me faz pensar que o câncer é mais temido (Natália, assistente social).

[...] sinto que, na sociedade, existe uma mobilização muito maior para ajudar as crianças com câncer; existem várias organizações em prol dessas crianças, enquanto outras doenças que também mereceriam uma atenção, não recebem (Eduarda, enfermeira).

Para a enfermeira Eduarda não é necessário um cuidado potencializado ou diferenciado aos pacientes com câncer, justificando que há outras enfermidades que geram até mais restrições à existência de pacientes do que o câncer e enfatizando a possibilidade de cura que o câncer oferece. Portanto, diferentemente da assistente de enfermagem Clara, a enfermeira Eduarda não vê os pacientes com câncer como crianças mais sofridas do que aquelas que vivenciam outras enfermidades, logo, não sente necessidade de destinar a elas cuidados diferenciados.

Eu costumava dizer para minha família, que o tumor não era a pior das doenças... que a gente observava, aqui, doenças piores que traziam muito mais restrições e incapacidades às crianças, que impunham regras que me fazem pensar sobre a qualidade de vida que você está proporcionando a ela [a criança] (Eduarda, enfermeira).

[...] um cardiopata vai ter que ter um controle muito rigoroso com a alimentação... a criança não pode correr porque vai sentir muito cansaço; ou uma criança dependente de oxigênio que vive naquele espaço em que o catéter vai oferecer o oxigênio; ou uma criança com insuficiência renal crônica que tem a vida controlada em função da diálise ou da hemodiálise. [...] o câncer, pode ser curado (Eduarda, enfermeira).

Em concordância com a enfermeira Eduarda, a assistente social Natália enfatizou que, apesar das singularidades, alguns aspectos da situação de adoecimento por qualquer enfermidade crônica, como as queixas, angústias e preocupações, são vivenciados de forma muito semelhante por pacientes e familiares. Isso faz com que o foco do cuidado prestado por ela, em diferentes setores da Pediatria, não seja tão diferente, sendo os atendimentos voltados, principalmente, para o acolhimento e o suporte da família na descoberta do diagnóstico e para o auxílio à reorganização familiar diante do diagnóstico de uma doença crônica.

Apesar das patologias serem diferentes, tem muitas coisas que demandam em comum, no sentido do acolhimento da família, da descoberta do diagnóstico... as famílias terão que se reorganizar em função de uma doença crônica... Isso se repete! [...] os mesmos abalos que as famílias de crianças que têm câncer apresentam, percebo que isso também aparece nas outras clínicas. Há famílias que vão conseguindo se adaptar mais rapidamente, outras não... [...] esses movimentos acabam sendo repetitivos mesmo: as 
queixas, as angústias, os filhos que estão em casa, os irmãos que estão sentindo... tudo bem parecido... interessante! (Natália, assistente social).

Quando uma outra doença crônica chega, esse medo [da morte] também se encontra muito próximo... e as vivências hospitalares também tendem a se repetir nas famílias (Natália, assistente social).

Na verdade, o que a assistente social Natália nota é que, independentemente da enfermidade crônica, o que há de diferente é a repercussão do adoecimento em crianças comparada à repercussão em adolescentes. Para ela, os adolescentes, em geral, são mais impactados pelo adoecimento, por já estarem vivenciando um período de transição marcado por profundas mudanças. Logo, a doença vem como mais um fator que altera o curso da vida desses jovens.

[...] o adolescente está passando por um processo de transição, iniciando ainda um projeto de vida... é... é... para o adolescente, a gente percebe que isso [o adoecimento] tem um impacto maior. [...] A criança, ela vai conseguindo lidar... o adolescente também, mas percebo que é mais uma mudança e acaba refletindo bem mais para o adolescente (Natália, assistente social).

Vale lembrar que, além de atuar na Pediatria como um todo, a assistente social Natália desempenha o trabalho de assistente social em um Centro de Atenção Psicossocial a usuários de álcool e drogas (CAPS - AD) na cidade de Ribeirão Preto. Ela estabeleceu uma comparação entre esses dois contextos de trabalho e comentou que, em ambos os casos, o sofrimento de pacientes e familiares é intenso e a possibilidade de morte está presente. Explicou que as dificuldades que enfrenta no CAPS-AD envolvem, principalmente, a adesão de pacientes ao tratamento bem como suas recaídas frequentes. Ela pontuou que o fato de trabalhar com enfermidades crônicas auxilia seu trabalho no CAPS-AD, pois consegue trabalhar com os usuários de álcool e drogas que, diferentemente dos portadores de doenças crônicas que foram acometidos pela enfermidade sem que a tenham escolhido e não têm a oportunidade de escolher renunciar a essa doença, eles possuem essa possibilidade de escolha, o que lhes permite, através de ajuda profissional, rever o trajeto até então traçado e construir novos caminhos baseados em escolhas saudáveis.

A minha outra área de trabalho é com usuários de álcool e drogas, no CAPS... então, são duas áreas muito pesadas. Percebo que é um trabalho também árduo, com uma clientela que tem uma difícil adesão ao tratamento, que tem recaída (Natália, assistente social). 
[...] aqui [Oncologia Pediátrica] a doença vem, não é por uma escolha da pessoa... ela [a doença] vem e acomete a pessoa; já na questão da droga, também tem sofrimentos intensos, mas dá para você mudar o percurso, se a pessoa desejar e se ela tiver um suporte para ajudá-la a fazer outras escolhas para que ela siga um caminho diferente (Natália, assistente social).

[...] a morte, também, é muito próxima dessas pessoas [usuários de álcool e drogas] a partir do momento em que elas se colocam em risco. Mas, estando lá no CAPS, percebo que essa vivência aqui [Pediatria] me ajuda a possibilitar conversas a partir das quais a pessoa [usuário de álcool e/ou drogas] possa refletir sobre essas escolhas, buscar outros caminhos, outras propostas. [...] acho que a morte pode estar iminente no contexto das drogas, mas é um pouquinho mais distante comparando com uma doença que acomete [a pessoa] e que, por mais que você queira fazer... Com relação à dependência química, tem sempre um pouquinho mais, e aí, depende da pessoa buscar esse 'a mais'... enquanto que, em alguns tratamentos aqui, esse 'a mais' se esgota! [...] na drogadicção, esse caminho pode ser um pouquinho mais longo, se a pessoa conseguir escolher coisas diferentes para a vida dela... mas, é um processo longo também... também não é fácil, também tem sofrimento, então, tem coisas muito parecidas aqui com a enfermaria! Mas, com relação à drogadicção, tem uma 'vírgula' que permite fazer escolhas diferentes! (Natália, assistente social).

\subsection{A ESSÊNCIA DO CUIDAR EM ONCOLOGIA PEDIÁTRICA: SIGNIFICADOS}

O psicólogo Tadeu e a assistente social Regina foram os únicos profissionais que abordaram a atuação em Oncologia Pediátrica diferenciando alguns aspectos da assistência às crianças do atendimento prestado aos adolescentes.

Para o psicólogo Tadeu, a função primordial da sua atuação junto à criança é a brincadeira e a diversão; é um estar-com independente do prognóstico do paciente, sendo as ações terapêuticas e educativas consequências desse encontro.

[...] lidar com crianças para mim [...] em contexto de trabalho, é algo muito diferente, porque quando estou com uma criança, eu brinco que regrido um pouquinho [risos]... também sou criança! (Tadeu, psicólogo).

[...] se eu for escolher um brinquedo, enquanto profissional, para brincar com uma criança, não é porque o brinquedo é educativo, é porque ele é divertido... brinquedo foi feito para brincar, e não para ensinar; o ensinar, o trabalhar são consequências. Então, estar com a criança é por estar com a criança... se aquilo é terapêutico, se aquilo vai reverter em alguma coisa, é uma consequência do meu trabalho (Tadeu, psicólogo). 
[...] se eu estava com o pai ou com uma criança, eu estava interessado nela... Não é nem em fazer um bom atendimento, não é nem saber se vai viver, se vai morrer, se vai curar... é nela! (Tadeu, psicólogo).

Com relação aos pacientes adolescentes, o psicólogo Tadeu significa como prazeroso compartilhar com eles seus momentos de escolhas e decisões, participando de suas descobertas. Porém, sente que, aliado ao prazer, há também um desafio que permeia esse estar-com: a situação de adoecimento evidencia e escancara as incertezas do futuro, o que dificulta planejamentos e sonhos.

[...] tenho uma boa comunicação com adolescente... acho um barato... acho difícil pra caramba, mas adoro! É aquela coisa: o que é que eu vou fazer da minha vida? O que é que eu vou fazer da minha vida no momento que minha vida também não sabe o que vai fazer com ela. E, poder conversar, poder descobrir uma série de coisas com os adolescentes, pra mim, é delicioso! [Fala com empolgação e brilho nos olhos] (Tadeu, psicólogo).

A assistente social Regina, ao estabelecer uma comparação entre o cuidado oferecido por ela às crianças e a assistência ofertada aos adolescentes, revelou sentir mais dificuldade para trabalhar com adolescentes por sentir que eles são mais exigentes.

Acho que com adolescente é um pouco mais difícil, porque eles exigem um pouco mais da gente, não assim... eu, enquanto assistente social, mas como com qualquer profissional que trabalha com ele (Regina, assistente social).

Com exceção dessas especificidades mencionadas, os profissionais entrevistados atribuem diferentes significados à experiência do cuidado em Oncologia Pediátrica, tanto com relação à assistência às crianças como aos adolescentes.

Para facilitar a compreensão do leitor, essa categoria foi dividida em sete itens: Acolhimento, escuta e acompanhamento; Atenção às necessidades singulares de pacientes e seus familiares; Envolvimento, empatia e manifestação de sentimentos permeando o cuidado; Respeitar, solucionar dúvidas e fornecer informações; Um cuidado que transcende o momento presente e que atente aos aspectos psicológicos e sociais envolvidos no processo de adoecimento; Facilitar a comunicação e a responsabilização pelo próprio existir; Cuidado aos pacientes terminais e aos familiares enlutados. 


\subsubsection{ACOLHIMENTO, ESCUTA E ACOMPANHAMENTO}

A assistente social Regina pontuou que ela utiliza o acolhimento e a escuta como formas de desempenhar um cuidado a pacientes e familiares por possibilitarem, inicialmente, o estabelecimento de contato com os mesmos, o acolhimento após o impacto do diagnóstico e o conhecimento de suas necessidades.

[...] quando elas [famílias] chegam, deparam-se com esse hospital enorme, com pessoas que elas nunca viram, com equipe desconhecida... comigo, que também sou desconhecida para elas. Então, até que eu consigo fazer o contato com elas, até elas confiarem e falarem as coisas para mim, então, assim... é todo um trabalho! (Regina, assistente social).

[...] no primeiro momento, é necessário estar ouvindo a família, ouvindo o que ela tem para te passar e ver o que nós, enquanto equipe, temos para oferecer (Regina, assistente social).

A enfermeira Eduarda também faz uso da escuta com o objetivo de conhecer a história de cada paciente e seu grau de informação sobre o adoecimento e o tratamento.

[...] aqui, embora seja corrido, seja um hospital de alta complexidade [...] a gente [a equipe de enfermagem] procura o tempo para parar e conversar. [...] entender o que está acontecendo, compreender que mundo essa criança vive, o que ela sabe daquilo tudo (Eduarda, enfermeira).

Alguns participantes enfatizaram a importância do acompanhamento e da escuta para a assistência em saúde, principalmente em circunstâncias em que essas são as únicas possibilidades que o profissional sente que possui para exercer o cuidado.

[Cuidar] é estar ali do lado, junto, segurando a mão, porque às vezes, você não tem o que falar, mas sabe que aquilo conforta (Eduarda, enfermeira).

[...] às vezes, você não tem nada para falar, mas só de você estar ali, ouvindo e ela colocando o que ela quis... (Regina, assistente social).

[...] acho que o cuidado é ficar do lado e eu já fiz algumas vezes isso... tá passando 'Malhação’ [novela] e eu falo: 'Vou assistir aqui com você, pode?' (Tadeu, psicólogo).

[...] isso é o barato do cuidado: estar próximo! (Tadeu, psicólogo). 
O acolhimento, o acompanhamento e a escuta apareceram como formas de expressar aos pacientes e familiares que eles não estão sozinhos, que há companheiros dispostos a ajudá-los nesse percurso que envolve o adoecimento e o tratamento.

Não é que eu vou pegar o outro no colo e falar que nada de mau vai acontecer; mas:'tá acontecendo algo de mau? Eu estou aqui do seu lado, o que você precisar de mim, dentro das minhas possibilidades, nós estamos juntos!' (Tadeu, psicólogo).

Teve muitas mães que falaram que iam desistir, que não estavam dando mais conta [...] Mas você... conversando, entendendo, dando condições para elas, falando: 'você vai conseguir, a gente está aqui como suporte... não tem jeito de resolver tudo... mas, a gente está aqui, vai te ouvir, te orientar e você vai dar conta!' [...] a gente está ali para tudo! (Regina, assistente social).

Eu me coloco à disposição (Júlio, médico).

O médico Júlio contou que disponibilizar um período da consulta para escutar seus pacientes reflete não só em bem-estar para eles, mas também para si. Apesar disso, ao exemplificar uma situação em que ele estendeu a consulta para ouvir as queixas de uma paciente, permitindo que ela expressasse seus sentimentos de raiva, revolta e sofrimento, o profissional descreveu sua atitude atribuindo um sentido a ela de desvalia, desmerecendo-a, mesmo tendo percebido o quanto sua postura contribuiu para o bem-estar da paciente. $\mathrm{O}$ fato de o médico significar sua conduta como de pouco valor, nos faz pensar que ele a compara com outras atividades por ele realizadas, mas associadas a práticas médicas, talvez consideradas por ele como de maior relevância.

Semana passada, veio aqui uma pessoa que trato com mieloma e ela [...] sabe que o mieloma é incurável. [...] Ela vai morrer de Mieloma e sabe disso. Ela já está aqui faz uns cinco anos e 'tá' acabando, porque não tenho muitas armas mais e vai terminar, e ela está com dor. [...] ela entrou aqui irritada e falou, xingou e chorou... Eu escutei e falei pra ela: 'Fulana, você não fez nada de errado pra ter essa doença, mas tem. Se você ficar a cada minuto perguntando 'Por que comigo?', você não vai viver o que tem aí, não sei quanto tempo tem pra gente caminhar'. Eu não falei nada, só fiz um comentário. Mas ela saiu daqui rindo, andando muito melhor do que quando ela entrou; ela precisava de falar, ela precisava de conversar, ela não precisava de mais nada. [...] Você para o consultório! [...] E um monte de gente esperando, reclamando e falei: 'Gente, hoje teve um problema e é dominó: um atrasa, os detrás vão tudo atrasando! Não tem jeito’. Mas, você percebe? Ela saiu rindo e eu não fiz nada [...] Não fiz nada, mas o simples fato de você deixar a pessoa conversar e pontuar alguma coisa ali... [...] quando acontece isso, como eu disse, me satisfaz. Eu gosto, eu tô... eu tô sentindo que eu tô tentando, cada vez mais, por mais tempo pra isso! Eu vejo que tem me feito bem também (Júlio, médico). 


\subsubsection{ATENÇÃO ÀS NECESSIDADES SINGULARES DE PACIENTES E SEUS FAMILIARES}

Para o psicólogo Tadeu, um cuidado de qualidade está associado à atenção às necessidades singulares de pacientes e familiares. Mas ele acrescentou que atuar em Oncologia Pediátrica é um trabalho complexo, que não envolve a mera aplicação de técnicas. Atender às necessidades singulares de pacientes e familiares requer não somente vontade ou disponibilidade, mas também criatividade e flexibilidade, além de um bom conhecimento e entrosamento com a equipe de saúde.

Oncologia Pediátrica é uma clínica difícil para todas as especialidades da saúde... é complexa: não é dou esse remédio, faço esse manejo clínico ou faço terapia enfocando isso e tá tudo ok. Não, não é! Já que não é assim, vamos embora! Vamos ser criativo! (Tadeu, psicólogo).

Tem dias que eu vou caminhar com o paciente no jardim e atendê-lo no jardim! É estar no movimento do outro desde que não me violente e que isso tenha um quê de criatividade, de inédito, de possibilidade... Isso me faz bem! (Tadeu, psicólogo).

Um paciente não vai à escola, está com dificuldades, então, é isso que ele está precisando? Vamos fazer a escola ali, no atendimento... Qual é o problema?! Vamos inventar! (Tadeu, psicólogo).

Às vezes, o paciente não lembra nada que eu falei, mas lembra de um dia que eu o ajudei a carregar sua mala de uma enfermaria à outra, quando não tinha ninguém para ajudá-lo. Isso faz a diferença e às vezes, é isso que a gente precisa fazer (Tadeu, psicólogo).

Eu me lembro do primeiro atendimento que eu fiz [...] Ela [a criança] olhava assim para o estacionamento lá fora e chorava. Chorava querendo ir embora e a mãe não sabia o que fazer. Eu passei acho que umas duas horas no quarto conversando, conversando com a mãe, conversando com a criança. [...] Eu pensei: [...] o que é que essa criança precisa? Precisa... ah, tá sentindo muita saudade de casa? Então, por que não trazer essa casa para o hospital? [...]! Eu cheguei e perguntei o que ela gostava no quarto dela e ela me falou do mural e da Barbie e eu falei: 'ok, vamos perguntar pra enfermeira, agora, se você pode trazer!’. [...] podia, né! Então, o meu cuidado foi esse... transformar o hospital no quarto dela! [...] Aquela minha ação no começo, que foi tão simples, de perguntar para a criança: o que você quer agora?... de pensar na criança... eles [mãe, pai e tia] referiram que determinou como eles lidaram com a situação (Tadeu, psicólogo).

À semelhança de Tadeu, a nutricionista Denise também pontuou a necessidade de flexibilidade para conseguir exercer uma assistência que atenda às necessidades singulares de pacientes e familiares. Para ela, a atuação em Oncologia Pediátrica exige posturas e 
estratégias diferentes daquelas que comumente utilizava em sua atuação como nutricionista e, por isso, ela teve que rever suas técnicas e adaptar seus conhecimentos para conseguir oferecer uma assistência de qualidade. É possível notar que a profissional possui capacidade de deixar-se surpreender, de lidar com o inédito e, com isso, consegue mobilizar estratégias alternativas mais eficazes para seu trabalho.

\begin{abstract}
A gente tem aquela questão dos pedidos extras... tem o cardápio padrão, mas àquelas crianças que não estão comendo muito bem, a gente oferece algumas coisas extras. [...] No caso, era um sorvete de chocolate [...] Eu tinha certeza que ela ia conseguir ingerir e a criança negou o sorvete! [demonstra surpresa]. [...] Ver uma criança de três, quatro anos de idade negando um sorvete de chocolate, mexeu muito comigo! Pensei: 'Poxa, preciso pensar em outras estratégias!' porque o que eu tinha de conhecimento até ali, caiu por terra! A gente pensa numa guloseima, algo que toda criança gosta, achando que eu ia conseguir que essa criança tivesse uma ingestão com caloria, com energia através desse sorvete e... não foi! (Denise, nutricionista).
\end{abstract}

A enfermeira Eduarda ressaltou a importância de se atentar tanto às necessidades de pacientes como às necessidades de seus familiares. Ela demonstrou disponibilidade para desempenhar um papel de porta-voz dessas necessidades para os demais colegas de trabalho.

[...] tenho que levar em conta a criança e as necessidades dela naquele momento. Em função disso... vou discutir [ela refere-se aos residentes], vou discordar, vou impor o que estou pensando sobre aquilo, para tentar valer o que aquela família, aquela criança está precisando [...] não dá para pensar só nela sem levar em consideração a família (Eduarda, enfermeira).

A assistente de enfermagem Clara atua na parte ambulatorial do tratamento, mas contou que os pacientes costumam requisitá-la, mesmo quando estão na enfermaria ou em casa, e ela demonstra possuir disponibilidade para atender ao pedido desses pacientes e fazer o que está ao seu alcance para ajudá-los. Percebo, na fala da participante, um sentimento de conforto pelo fato de os pacientes demonstrarem desejo de tê-la por perto. Foi possível perceber que, assim como a enfermeira Eduarda, essa profissional funciona como referência para pacientes em tratamento e seus familiares, o que é reflexo de um trabalho cuidadoso desempenhado por ela.

Tem uns [pacientes] que [...] até na hora que eles estão ruim, eles te 'chama'. Tem muitos que eu vou lá em cima [ela refere-se à enfermaria, já que ela atua apenas na parte ambulatorial do tratamento], porque eles pedem para os pais me chamar e eu vou...[...] Teve uns que eu já fui até na casa (Clara, assistente de enfermagem).

[...] eles [os pacientes] solicitam muito... eles estão morrendo... estão com medo e te pedem ajuda (Clara, assistente de enfermagem). 


\section{Assim como a enfermeira Eduarda e a assistente de enfermagem Clara, a} assistente social Regina também demonstrou desempenhar um papel de referência para pacientes em tratamento e para seus familiares, intermediando a relação entre eles e os demais profissionais da equipe de saúde, o que, segundo a participante, é facilitado pelo fato de ela estar muito presente no hospital.

[...] a maioria [das mães] não fala para o médico, porque acha que tem uma distância muito grande entre o médico e o paciente, entre o médico e a família, e traz isso para gente... então, a gente leva para a equipe: 'Olha, tá acontecendo isso...' (Regina, assistente social).

Quando acontece o óbito, elas [as mães] descem... [da enfermaria para o ambulatório, onde ela trabalha]! (Regina, assistente social).

[...] por eu estar lá seis horas todos os dias, meu vínculo é muito grande com a família! Ela entra lá e chora, entra lá para falar o que está acontecendo, o que vai acontecer, que não vai dar conta... (Regina, assistente social).

\subsubsection{ENVOLVIMENTO, EMPATIA E MANIFESTAÇÃO DE SENTIMENTOS PERMEANDO O CUIDADO}

Alguns profissionais entrevistados contaram que, no período de sua formação, foram orientados a não se envolverem emocionalmente com os pacientes. Porém, todos que abordaram essa temática revelaram discordar dessa orientação.

[...] na minha formação, o enfermeiro ainda não podia se envolver, o enfermeiro que se envolvia, trazia complicações para si. Eu já acho o contrário e isso, desde quando entrei (Eduarda, enfermeira).

[...] quando saí da faculdade [...] o nosso chefe, já falecido, que fundou a Hematologia [...] falou assim: 'Nunca se envolva emocionalmente com os pacientes'. Não consegui [risos] e eu 'tô' piorando cada vez mais! Me envolvo, dou palpite nas vidas, paro, sou chato pra caramba! (Júlio, médico).

A assistente social Regina contou que, para ela, é difícil não se envolver quando se trata de uma relação estabelecida em um contexto de adoecimento, sofrimento e tratamento longo. Ela percebe que não só ela, mas a maioria dos profissionais também demonstra envolvimento com pacientes e familiares. 
É muito fácil outros profissionais falarem: 'Não se envolva!'. É diferente. Acho que quando você está ali [...] a gente acaba se envolvendo (Regina, assistente social).

[...] acho que todos os profissionais da Oncologia [Pediátrica] são bem envolvidos com os pacientes, por se tratar de uma doença que, muitas vezes, não tem cura, por todos os procedimentos dolorosos, toda a duração... a gente acaba convivendo muito com eles... então, toda a equipe acaba se envolvendo! (Regina, assistente social).

[...] não sei se é bom ou ruim, mas a gente acaba se envolvendo com todo mundo, porque o carisma da criança, a dificuldade que a mãe tem e que você vai trabalhando, o tempo de tratamento que você passa a conviver com uma criança ali ou com um adolescente... dependendo do tratamento, são uns dois anos! (Regina, assistente social).

A assistente social Natália também pontuou que o tratamento prolongado torna esse envolvimento natural.

Até porque é uma doença em que os pacientes ficam um bom tempo internados [...] a gente se vincula à criança, à família... então, é uma vivência importante [...] tem crianças e famílias que ficam muito tempo aqui e você acaba se vinculando, quer queira, quer não! (Natália, assistente social).

Com relação ao cuidado prestado pela terapeuta ocupacional Ana, ficou clara sua capacidade de estabelecer relacionamentos permeados por empatia e envolvimento, devido à sua abertura para ser tocada pelas vivências do outro.

Durante o atendimento, chego a ficar emocionada e aí, você tem que se segurar para não afundar ainda mais o paciente [Ri]. [...] mas, às vezes, você se segura ali, durante o atendimento, para chorar lá fora, depois (Ana, terapeuta ocupacional).

Ele [o paciente] chorava de dor e gritava... e assim, ninguém estava conseguindo fazer o manejo adequado dessa dor. [...] Foi sair de lá de dentro do quarto e desabar assim [ri], pensando no quanto estava sendo sofrido pra ele... me colocando no lugar dele (Ana, terapeuta ocupacional).

Para o médico Júlio, o envolvimento é benéfico, pois permite estabelecer um melhor relacionamento com pacientes e familiares, permeado por liberdade e intimidade. Além disso, crê que esse envolvimento facilita a adesão do paciente ao tratamento e às orientações médicas. Revelou que não estabelece uma relação de superioridade para com seus pacientes e familiares e busca tratar e cuidar de todos da mesma maneira, independente da posição social que cada um ocupa. O profissional percebe que essa forma de se relacionar com seus pacientes e familiares torna o tratamento e a convivência mais "leve”, além de facilitar o 
enfrentamento do adoecimento por parte das pessoas envolvidas. Porém, reconhece que esse envolvimento gera sofrimento para si.

[...] estou me envolvendo muito mais, atualmente, do que no passado! Me envolvo... sofro! (Júlio, médico).

O que te digo é que a família melhora [quando a relação médico-paciente é permeada por envolvimento] e tenho certeza do que estou falando! Porque o cara que fica aqui atrás, no pedestal, que não dá atenção... não tem intimidade... porque o paciente não te liga, porque ele fica com medo de te ligar, se você não dá essa liberdade [...] o que já pode atrapalhar muito. Segundo, será que adere tanto? Tipo, 'Ó, tem que tomar isso', o cara pensa 'ah, não vou tomar essa porcaria não e tal!’. [...] Já, quando você se envolve, você vai, o pessoal dá importância a isso. Acho que funciona muito melhor! (Júlio, médico).

Aqui, a gente nunca fica em cima de um pedestal... permite que telefone... isso pra todo mundo... [...] aqui, todos recebem o mesmo tratamento [...] gente muito humilde recebe o mesmo tipo de tratamento, os mesmos horários, o mesmo cuidado que o filho do médico com Leucemia. [...] Esse jeito de ser é muito mais gostoso! E, esse enfrentamento, como vocês [psicólogas] falam lá [refere-se ao HC], fica muito menos pesado! (Júlio, médico).

Com relação à manifestação de sentimentos, alguns profissionais comentaram que, diferentemente de outros contextos, em que os profissionais de saúde são orientados a conter seus sentimentos e a evitar envolvimento, na Oncologia Pediátrica, há abertura para a manifestação de sentimentos no cuidado prestado a pacientes e familiares.

[...] aqui, a gente chora [...] não tenho vergonha de chorar... choro sim... choro do lado da mãe, choro do lado dela [da criança] (Eduarda, enfermeira).

[...] as mães vêm, choram e você chora junto (Regina, assistente social).

[...] quando a gente está estudando, há uma construção bem acadêmica que diz: 'Não chore!', mas quando você vai para a prática, no começo, você fica brigando muito, como se fosse uma camisa de força... Mas, na verdade, com o tempo, você vai amadurecendo e vendo que dá para estar junto, sem perder seu objetivo, seu aspecto profissional... (Natália, assistente social).

Tem momentos que posso chorar, né, que não vou conseguir me segurar! Quando eu der conta, tudo bem, mas às vezes, não precisa! Tem hora que a mãe vem, te abraça chorando, então... não tem jeito... tem hora que faz parte! (Natália, assistente social).

O médico Júlio dividiu sua percepção de que, no HCFMRP-USP, os profissionais da Pediatria, em comparação com os profissionais da Hematologia Clínica, possuem um maior envolvimento com seus pacientes. Ele explicou que, na relação com pacientes e familiares, 
esses profissionais permitem-se demonstrar seus sentimentos e possuem capacidade e disponibilidade para acompanhar pacientes terminais até o óbito.

[...] eu convivo em poucos ambientes, que é o HC e aqui [consultório particular]. Lá [Oncologia Pediátrica], percebo a formação que é dada [...] o cara [profissional] participa mesmo! E ela é completamente diferente, olha só, da 'Hemato-Clínica'! Aquilo que vocês veem na Pediatria, não... na 'Hemato-Clínica', o pessoal [os profissionais] é muito mais frio, muito mais distante! Eu percebo isso claramente [...] É diferente! Agora na Pediatria... o pessoal abraça... vai até o fim junto [...] e isso é bom! (Júlio, médico).

Para a assistente social Natália e para o psicólogo Tadeu, a possibilidade de o profissional expressar e compartilhar sentimentos com pacientes e familiares reverte em melhor qualidade de atendimento, por possibilitar demonstração de compreensão, proximidade, acolhimento e empatia.

Se eu estou triste, eu choro em atendimento, mas eu choro em função do outro. Eu mostro que eu tô triste, mas eu não choro 'aiaiai' [imita], mas: 'Olha, mãe, eu estou tocado com sua história' e às vezes, ela olha e fala: 'Nossa, que bom que alguém me entendeu!' (Tadeu, psicólogo).

[...] permite ao outro pensar o quanto você está compartilhando a dor, realmente [...] Nos atendimentos, você sente que a pessoa tem que se dar conta de que você está muito próximo [...] É estar lado a lado! (Natália, assistente social).

\subsubsection{RESPEITAR, SOLUCIONAR DÚVIDAS E FORNECER INFORMAÇÕES}

Os profissionais entrevistados pontuaram, também, a importância de prestar uma assistência que respeite os limites estabelecidos por pacientes e familiares. É um ser-com sem ser invasivo.

Eu vou ao mundo do outro! Eu vou até onde posso, até onde me é aberto; nunca serei invasivo... se ele me coloca o limite dele, eu respeito! Se ele me fala, 'Então, hoje eu não quero conversar', por mim, tudo bem. Eu falo: 'Tem alguma coisa que eu poderia ajudar? Tá sentindo alguma dor?' Quando vou embora, dou um 'tchauzinho', é respeitar! É respeitar absolutamente! Se aquele dia a mãe quer chorar, quer ficar sozinha, me coloco à disposição, dou meu lencinho para ela e falo que se ela precisar, ela me chama. Se a criança está vendo um desenho, se para ela for mais importante ver o desenho, se eu tiver outro tempo, eu volto depois [...] Eu falo que, por mim, 
tudo bem, que vou conversar com a mãe dele. É isso, é o respeito! Não é porque a criança está com câncer ou porque ela vai morrer ou está morrendo... É que a criança tem que ser respeitada, essa é uma compreensão de ser humano (Tadeu, psicólogo).

Lembro que conversei com ele, conversei com a mãe e ele não quis realizar nenhuma atividade e eu respeitei... (Ana, terapeuta ocupacional).

O médico Júlio comentou sobre a necessidade de respeitar o período de adaptação de pacientes e familiares após descoberta do diagnóstico. Nesses momentos, além de respeitar, ele busca oferecer informações claras sobre o adoecimento e o tratamento, por acreditar que elas proporcionam tranquilidade e auxiliam no enfrentamento do adoecimento.

[...] aprendi que o tempo... ele é o senhor da razão... o tempo é sábio, é o tempo que faz com que as coisas se acomodem. Então, o cara está no começo do tratamento... calma, que ele vai se acostumar. [...] Eu uso sempre essa expressão [...] 'Olha, o que eu estou fazendo é colocando uma cruz nas costas da senhora: essa doença do seu filho é uma cruz que a senhora vai falar que não vai aguentar no primeiro dia, você vai levantar daqui e sentar de novo, falando que não dá. Daqui a uma semana, você já está vendo que ela já está se acomodando ali. Daqui a dois meses... aí, pronto, a senhora carrega como um relógio que a senhora carrega e não sabe que tem ele no pulso... e vai ser essa a cruz... mas, ela existe. Ela existe e vocês vão caminhar juntos até o final do tratamento'. Sempre uso isso, porque é invariável isso; o comportamento no início é um, e sempre vai melhorando, por mais arredio, sempre... por mais humilde... A pessoa começa a entender e isso é outra coisa que a gente faz questão! Explicar a doença, sempre, dentro do que a pessoa entende! Entendeu, bem, não entendeu, ele vai te perguntando e você vai falando. É aquilo... essa senhorinha que você viu saindo daqui, provavelmente não sabe nem escrever direito, ela sabe como é a doença, que é leucemia, como é o comprimido... (Júlio, médico).

[...] quando vai fazer o diagnóstico, é como se fosse no automático! Você vai conversando com a família e, no primeiro dia, você já responde $90 \%$ de todas as perguntas que estão guardadas ali dentro; os outros $10 \%$, você deixa a porta aberta para ela te ligar ou nos retornos fazer [as perguntas] (Júlio, médico).

A assistente social Regina também comentou sobre a importância de os profissionais estarem preparados para informar e orientar os pais sobre a adesão ao tratamento.

Muitas mães falam: [...] Será que meu filho tem que passar por isso?’ E você tem de estar preparada para conversar com a família e falar da importância de se fazer aquilo [o tratamento] (Regina, assistente social). 


\title{
6.2.5 UM CUIDADO QUE TRANSCENDE O MOMENTO PRESENTE E QUE ATENTE AOS ASPECTOS
} PSICOLÓGICOS E SOCIAIS ENVOLVIDOS NO PROCESSO DE ADOECIMENTO

Para a enfermeira Eduarda, cuidar requer uma assistência que vá além do momento presente, sendo necessário que o profissional reflita sobre as repercussões psicológicas e sociais que determinados procedimentos podem ocasionar aos pacientes, buscando minimizar possíveis traumas. A preocupação da enfermeira, com relação a essas repercussões psicológicas e sociais, mostra que ela assume uma postura de reflexão e questionamento a respeito de como desempenhar um cuidado de qualidade. Entretanto, sua fala revela a angústia e a impotência de saber que precisa realizar determinados procedimentos, apesar de ter conhecimento de que os mesmos podem gerar sequelas e implicações futuras na vida dos pacientes.

\begin{abstract}
Às vezes, você tem que fazer determinados procedimentos para uma doença que vai causar mutilações nessa criança. Eu tento pensar: ' $O$ que vai ser isso no futuro?’. Eu tô pensando na criança hoje, mas tenho que entender que ela vai crescer e, como é que fica isso no futuro dela? [...] Tinha uma criança que precisava de lavagem intestinal com frequência e aquele procedimento parecia... um estupro! Estavam forçando ela àquilo. Aí, eu questionava muito como ia ser ela adulta, a sexualidade dela, a interferência disso tudo na vida dela, porque isso é um trauma que ela vai carregar! Não dá para você só pensar naquele momento... As crianças que crescem com ileostomia ${ }^{8} .$. como que vai ser o relacionamento com outro? Como que vai ser o relacionamento sexual quando virarem adultos? (Eduarda, enfermeira).
\end{abstract}

Assim como a enfermeira Eduarda, o psicólogo Tadeu demonstrou estar atento para ofertar um cuidado para além do presente, focado no crescimento e no desenvolvimento das crianças, apesar de elas estarem atravessando um período de adoecimento. Essa atenção ao desenvolvimento de seus pacientes revela o investimento desse profissional no futuro deles, mesmo que eles corram o risco de não sobreviver.

[...] cuidar em Oncologia é cuidar de uma criança ou de um adolescente. Aqui eu 'tô' focando em uma criança, como qualquer criança! O que é que a criança precisa? É de limite? Então, eu vou tentar trabalhar o limite! (Tadeu, psicólogo).

A vida não é só adoecimento e isso faz uma diferença grande, muito grande (Tadeu, psicólogo).

\footnotetext{
${ }^{8}$ Abertura cirúrgica do íleo - parte do intestino delgado - que possibilita a evacuação das fezes através dela, na parede abdominal.
} 
[...] cuidar [...] é dar condições para que o paciente cresça... mesmo que vá morrer no dia seguinte (Tadeu, psicólogo).

Se a criança vai viver um dia, uma hora ou sessenta anos, não importa! Mas estou lidando com aquele ser humano e é isso, para mim, que vale a pena... que vale a pena investir! (Tadeu, psicólogo).

A terapeuta ocupacional Ana pontuou a importância de um cuidado que destine atenção não somente aos aspectos físicos, mas, também, aos aspectos emocionais, proporcionando aos pacientes momentos de saúde e prazer em meio à dor.

[cuidar] no sentido amplo da palavra, não só o cuidado de medicações, de tratamento clínico... Acho muito significativo, que a gente da T.O., da Psicologia, que vai até lá para dar apoio emocional, pra trabalhar no sentido de proporcionar momentos prazerosos, momentos de saúde dentro da doença... (Ana, terapeuta ocupacional).

O médico Júlio demonstrou estar atento às repercussões psicológicas do adoecimento no desenvolvimento de seus pacientes, relatando que recomenda a eles a busca por atendimento psicológico.

[...] sobre aspecto psicológico, sempre recomendo a procurar apoio, sempre! [...] recomendo e aí, fica muito a critério da família como fazer... muitos fazem e, na parte clínica, a gente toca! (Júlio, médico).

Quanto à dimensão social, o cuidado prestado pelo médico Júlio transcende o espaço hospitalar, pois busca criar uma rede social que auxilie no tratamento de seus pacientes, principalmente para pessoas de baixa renda, demonstrando engajamento e preocupação para com os mesmos. Além disso, busca orientar não somente os pacientes mas, também, seus cuidadores em relação ao adoecimento e ao tratamento e demonstra disponibilidade para entrar em contato com essas pessoas para avaliar se o tratamento está sendo feito adequadamente.

Essa menina [paciente que estava na sala de espera, quando eu também estava aguardando o profissional] quando começou a tratar, eu olhei e falei 'Ai, meu Deus...' [expressão de preocupação]. Ela mora numa casa com três cômodos e sete pessoas [...] Aí, criei uma rede danada [...] que a prefeitura [de uma cidade da região] tem uma ambulância no dia que ela vem aqui... ela chega aqui 6 horas da manhã, você viu. A quimioterapia, onde ela vai fazer, já é planejada pela prefeitura de lá; quando ela vai para lá e tem algum problema, a assistente social me liga... construíram um comodozinho [na casa da paciente], onde ela fica mais separada dos irmãos (Júlio, médico).

Ela [uma de suas pacientes idosas] sabe... a filha [que é a cuidadora] sabe... a filha que controla o remédio, porque checo... Checo aqui, checo na casa dela, com a moça que cuida lá (Júlio, médico). 


\subsubsection{FACILITAR A COMUNICAÇÃO E A RESPONSABILIZAÇÃO PELO PRÓPRIO EXISTIR}

O psicólogo Tadeu pontuou que seu papel profissional envolve, também, estimular que os pacientes se responsabilizem por suas escolhas. Além disso, ele busca facilitar a comunicação entre pacientes e familiares, bem como ajudá-los a se aproximar de questões que mobilizam angústia.

[Ele fala] 'Olha, fulano, você está aí assistindo 'Ben 10', seu desenho favorito! Hoje, só tenho esse horário para gente brincar! O que você prefere?’A criança fala: 'Ah, hoje quero ver desenho!'.

[...] às vezes, o meu trabalho é estar próximo vendo TV ou 'escancarando a ferida'... tocando em temas que estão velados, que eu percebo que estão velados e que precisam ser ditos. Eu vejo que a criança está sofrendo porque a mãe está sofrendo, mas não fala que está sofrendo! Isso é o cuidado, é abrir esse espaço! (Tadeu, psicólogo).

\subsubsection{CUIDADO AOS PACIENTES TERMINAIS E AOS FAMILIARES ENLUTADOS}

A assistente de enfermagem Clara demonstrou capacidade de mobilizar os recursos possíveis para oferecer um cuidado voltado para uma melhor qualidade de vida de seus pacientes. Para ela, oferecer conforto e qualidade de vida são possibilidades de cuidado, principalmente, quando não há mais caminho a ser percorrido em função da cura.

[...] você vê eles [pacientes] sofrendo... então, fica querendo fazer de tudo para eles terem, pelo menos, uma qualidade [de vida] maior, principalmente, esses terminais (Clara, assistente de enfermagem).

[...] quando vejo que eles estão sofrendo, com dor, alguma coisa que a gente possa fazer, assim... pra dar conforto, eu gosto de fazer (Clara, assistente de enfermagem).

O psicólogo Tadeu também demonstrou disponibilidade para exercer o cuidado junto a pacientes terminais. Nessas circunstâncias, o profissional busca acompanhar, escutar e auxiliar a expressão de seus pacientes. Para ele, essa disponibilidade para estar-com-o-outro em seus momentos finais é significada como uma entrega de si. 
[...] era uma adolescente e eu sabia que ela não ia... que eu não ia encontrar mais ela. Nada tinha me dito aquilo, mas por estar próximo da morte, a gente cria uma sensibilidade para quando a vida vai se extinguindo e eu queria dar vida pra ela, dar vida assim não... mas, oferecer a possibilidade de ela estar ali. Ela não conseguia falar e eu falei pra ela ir fazendo sim ou não [gesticulando], que eu ia tentando entender. Aí, eu me coloquei à disposição e acho que esse estar à disposição do outro é estar totalmente entregue (Tadeu, psicólogo).

O médico Júlio revelou sua disponibilidade para estar com pacientes e familiares nos momentos finais, quando não há mais possibilidade de cura, por acreditar que consegue prestar sua ajuda de outra maneira, não mais voltada para cura, mas para acolher ansiedades e minimizar sofrimentos. É possível notar que o profissional consegue significar que seu papel profissional não se limita a ofertar o cuidado na perspectiva de cura, mas que o cuidar também pode ser realizado junto a pacientes sem possibilidades terapêuticas e junto às famílias enlutadas. A assistência prestada pelo médico é permeada pela disponibilidade, escuta, abertura, compreensão e participação ativa, que lhe permitem conduzir o tratamento de seus pacientes de forma leve e criativa, sem rigidez ou distanciamento.

[...] faço trinta anos de formado; nos últimos dez, quinze anos, vou nos velórios das crianças e antes, eu não ia, nunca fui... ia raramente! Hoje, se é de Ribeirão e se eu posso, faço questão de ir lá... vou, cumprimento a família, me coloco à disposição. A hora que está terminando, é a hora que estou à disposição; vou a casa e vou ao velório [...] quando tá chegando lá [óbito], se você tá perto, você, pelo menos, tenta tirar as ansiedades [...] sempre procuro estar junto, não só para minimizar o sofrimento, mas também para conversar (Júlio, médico).

A assistente social Natália também demonstrou disponibilidade para exercer o cuidado junto às famílias enlutadas.

[...] no momento do óbito... [...] vou acolher, ter uma escuta, porque nessa hora a escuta e o acolhimento vão fazer uma diferença (Natália, assistente social).

Para a terapeuta ocupacional Ana, em comparação com as demais clínicas em que atua na Pediatria, a Oncologia Pediátrica é a mais avançada na questão de estabelecimento de cuidados paliativos. Na sua visão, os profissionais deste serviço demonstram abertura para tematizar esse momento através de discussões entre eles, demonstrando estarem atentos para diminuir o sofrimento de pacientes e não prolongar a vida a todo custo. Apesar dessa colocação, a profissional percebe que, em algumas ocasiões, seus colegas de trabalho acabam adiando essa decisão, mesmo quando pacientes e familiares expressam seus desejos de 
interromper um tratamento que não está tendo mais resultado, o que parece estar relacionado às dificuldades desses próprios profissionais de se depararem com seus limites profissionais.

[...] a equipe aqui da Oncologia Pediátrica é muito mais avançada em termos de cuidados paliativos do que outras equipes que pude ter contato. Eles aceitam muito mais e até pregam que, realmente, não se deve prolongar a vida a qualquer custo, que tem um limite, que tem que parar e dar alívio para o paciente. [...] Eles não estão na estaca zero, mas mesmo assim, às vezes você percebe que essa decisão é um pouco adiada, o paciente já está dando indícios que não quer mais, o paciente pede: 'não quero mais fazer biópsia, não quero mais colocar sonda... [...] às vezes, precisa do paciente ou do familiar falar, antes de eles tomarem a decisão, e tinha que ser o inverso (Ana, terapeuta ocupacional).

6.3. TOCAR O OUTRO E SER TOCADO POR ELE: UMA RELAÇÃO DE CUIDADO PERMEADA POR DESAFIOS E REALIZAÇÕES

A atuação em Oncologia Pediátrica é vivenciada pelos participantes de forma ambivalente, já que a maioria deles revela experimentar momentos de desgaste emocional e dificuldades acompanhados por sentimentos de satisfação e realização profissional.

Entre as dificuldades experimentadas, os profissionais citaram o contato com o sofrimento físico e psíquico, bem como o óbito de pacientes.

A enfermeira Eduarda ressalta o desgaste emocional ocasionado pelo contato frequente com a morte de pacientes, bem como a dificuldade de lidar com essa circunstância inerente à existência humana. Além disso, relembrou um episódio vivenciado em sua atuação profissional em que o desafio experimentado estava associado ao fato de entrar em contato com uma criança de tenra idade com uma capacidade ímpar de compreensão de sua condição de proximidade com a morte e que apresentava um desejo de cuidar para que a mãe lidasse bem com a despedida. A profissional revela a dificuldade de assistir a tal cenário e mediar esse diálogo, essa despedida entre mãe e filho.

A situação da morte é uma situação delicada, muito delicada e a gente vive aqui com frequência (Eduarda, enfermeira).

Semana passada foi uma semana assim... pesada... o clima é tenso, você sente energias... não diria negativas, mas energias difíceis de serem conduzidas. Tivemos uma criança que morou três anos no hospital com a gente e que morreu na quarta. Aí, junto a esse processo todo, temos uma 
criança com um sofrimento intenso dentro da 'Hemato', num processo de morrer angustiante em que uma criança de cinco anos conversa como se fosse um adulto: ele não fala diretamente que não quer morrer, mas pede à mãe que solicite ao anjo dele, que ele está vendo, que alivie as dores dele, que eram insuportáveis e, ao mesmo tempo, falava que não queria ir embora com o anjo porque a mãe não está preparada. Então, é um desgaste emocional muito grande (Eduarda, enfermeira).

O médico Júlio demonstra lidar com a morte de seus pacientes como uma batalha pessoal, revelando o desafio vivenciado, mas também seu envolvimento e engajamento no cuidado prestado aos mesmos.

Eu não sei perder [expressão séria]. [A dificuldade] é a hora que você não consegue e sabe que vai perder, ou a hora que você perde [...] quando você perde, é duro! Acho que não sou como o Wanderley Luxemburgo que diz: 'eu ganhei, nós empatamos, os jogadores perderam!' [Risos]. Não, nós perdemos! (Júlio, médico).

Além da dificuldade de entrar em contato com a morte, o médico Júlio pontuou a comunicação de fechamento de prognóstico a familiares de pacientes como outra dificuldade com a qual se depara em sua atuação profissional. O profissional explicou que, devido aos avanços da Medicina, várias doenças que, antigamente, não tinham cura, tornaram-se passíveis de tratamento; dessa forma, tem sido cada vez mais difícil para os médicos aceitarem o fechamento de prognóstico de pacientes. Ele comentou, também, o quanto é difícil explicar aos familiares de pacientes jovens que a Medicina não é sempre vencedora, que às vezes, ela é vencida, já que a morte permeia a existência do ser humano, independente do local onde o paciente está ou da posição social que ele ocupa. Para ele, é mais fácil lidar com pacientes "mal-humorados e chatos" do que com pacientes fora de possibilidades de cura.

A Medicina tem ficado... a Hematologia tem ficado cada vez... menos aceitando que não tem cura, que não tem tratamento. A gente nota claramente... eu 'tô' vivendo isso há trinta anos... tinha doença que, lá atrás, sabia-se que não tinha nem o que fazer e, hoje, você viu um senhor aí, que toma um remédio e que se fosse há quinze anos atrás, ele ia morrer; esse cara vai viver... vai morrer de velhice [...] ele tem Leucemia Mieloide Crônica e isso, hoje, com o Glivec, vai embora; mas, há dez anos atrás não tinha Glivec (Júlio, médico).

Você tem consciência que você trabalhou, que você fez tudo direitinho... infelizmente você tenta mostrar, o que é duro para um pai e para uma mãe, que a Medicina não ganha sempre. Então, outro dia mesmo [...] morreu o secretário da Saúde do Estado de São Paulo, de infarto. Quer dizer, tem coisa mais absurda do que isso? O cara morreu, o secretário da Saúde morreu, chegando no Incor. O Tom Jobim morreu de infarto em Manhattan. Quer 
dizer, morre! Infelizmente, morre! Morre de idade, de acidente, de doença! A Medicina não consegue ganhar sempre, mas é duro você mostrar isso para uma família! (Júlio, médico).

[...] é duro perder! Isso pra mim é o pior! Eu ligo menos pra paciente chato, e eu tenho: o cara que vem, entra aqui [faz expressão de mau humor] e eu quebro o gelo mesmo! No segundo, terceiro retorno, falo: 'Vai dar uma risada ou nós vamos ficar aqui nessa cara feia?’. O cara fica sem graça, você desarma! Então, na outra, ele já entra diferente! Entendeu? Não precisa! Eu sempre desarmo, porque precisa ter um bom ambiente. [...] Eu não sei perder! (Júlio, médico).

Nas falas anteriores do médico Júlio, fica claro que o profissional possui recursos para lidar com seus pacientes descritos como chatos: faz uso da conversa e do humor para minimizar as barreiras que os pacientes lhe impõem, criando um ambiente mais leve, o que facilita seu relacionamento para com eles. Apesar de ter mencionado anteriormente que o profissional consegue perceber possibilidades de cuidar mesmo em situações em que não há mais chances de cura, aqui, ele revela o quanto se sente impotente diante dessas situações, como se não tivesse o que oferecer a seus pacientes, experimentando sim dificuldades para lidar com essas questões. É possível perceber a dificuldade que ele sente para lidar com seus limites e com os sentimentos de impotência despertados ao entrar em contato com a realidade de que faz tudo o que está ao seu alcance e, apesar disso, algumas vezes, essa postura não é suficiente, pois não garante o sucesso do tratamento dos pacientes.

A assistente social Natália também revelou que a maior dificuldade que enfrenta em seu trabalho é o óbito de pacientes, não só pela dor de entrar em contato com a morte do outro, mas também pelo fato de a morte do outro aproximá-la de sua própria condição de serpara-a-morte. Segundo ela, o contato frequente com a morte em seu trabalho, fez com que ela se aproximasse mais de sua condição, já que antes de trabalhar no hospital estava mais distante desses acontecimentos e, por isso, não pensava tanto na questão da finitude.

[A maior dificuldade é] o óbito! Faz a gente entrar em contato com a morte mesmo, a todo momento... que nós somos frágeis mesmo... que a morte faz parte do cotidiano da nossa vida vinte e quatro horas por dia! Eu brinco que fui me dar conta disso trabalhando aqui! Quando a gente está lá fora, a gente não pensa muito sobre isso, mas aqui não tem jeito... a todo tempo você é convidado a pensar (Natália, assistente social).

[...] para mim, o óbito vem me aproximar ainda mais dessa realidade de que a gente tem um fim mesmo, que a gente morre (Natália, assistente social).

Os profissionais comentaram, também, sobre como reagem diante da perda de pacientes. Tanto a enfermeira Eduarda como o médico Júlio revelaram que se recordam, de 
forma muito vívida, dos pacientes que faleceram, o que mostra o quanto essas pessoas marcaram a trajetória profissional dos participantes.

Não dá para esquecer! Tem nove anos que estou aqui e lembro até hoje da primeira criança que morreu comigo (Eduarda, enfermeira).

[...] lembro de cada um dos meus pacientes, os que morreram, os que curaram. Lembro de gente que não vejo há uns quinze anos! Lembro de gente que eu tratei no HC, quando eu era residente há trinta anos atrás! Lembro direitinho! Lembro do meu primeiro paciente com doença maligna, lá no HC, que faleceu! E, essa é a parte chata! (Bernardo, médico).

A enfermeira Eduarda contou que o choro é mais uma de suas maneiras de expressar a dor pela perda de pacientes.

Tem os pacientes que você tem um apego maior e quando você tem esse apego, essa afinidade [...] a gente vive o luto; às vezes, recorda em casa e chora (Eduarda, enfermeira).

Ontem, ao descrever os cinco casos do meu estudo de doutorado, foram cinco casos que envolveram crianças que estavam morrendo... Ao recordar disso tudo, comecei a chorar (Eduarda, enfermeira).

A assistente social Natália revelou também que, diante da perda de pacientes, fica mobilizada. Apesar disso, contou que, após o choque inicial, consegue se restabelecer para continuar desempenhando sua tarefa. Ela acredita que a morte de pacientes tão jovens a mobiliza ainda mais pelo fato de ela ser mãe. Logo, parece que a maternidade facilita a empatia, permitindo que ela experimente, de uma forma ainda mais intensa, esse colocar-se no lugar do outro e sentir a dor daqueles que estão sofrendo a morte de alguém tão querido.

[...] fico bem mobilizada [em situações de óbito], mas consigo mover algum recurso para quando... se eu estiver aqui no momento do óbito... [...] vou acolher, ter uma escuta, porque nessa hora a escuta e o acolhimento vão fazer uma diferença [...] eu fico pensando, mas depois, vou conseguindo diluir, né! (Natália, assistente social).

[...] tento desvincular, mas não deixo de ficar mobilizada, ficar mais sensível [em situações de óbito de pacientes], ainda mais quando a gente é mãe! Eu percebo que minha sensibilidade aflorou ainda mais em relação a isso, porque vou chegar em casa, vou olhar para meu filho... (Natália, assistente social).

A terapeuta ocupacional Ana revelou ter mais dificuldade em acompanhar o sofrimento físico e psíquico de um paciente até o óbito, do que entrar em contato com a morte propriamente dita. Ela demonstrou sentimentos de impotência e angústia por perceber que 
nem sempre consegue encontrar formas eficazes para aliviar o sofrimento de seus pacientes. Foi possível perceber que, assim como para o médico Júlio, para essa participante, sentir-se impotente é um desafio em sua atuação profissional.

[...] a questão da morte e do morrer não é difícil para mim. Tenho mais dificuldade em acompanhar o sofrimento da criança até o óbito. Se está passando por muita dor, se está passando por um sofrimento físico, psíquico, essa parte é mais difícil para eu aguentar (Ana, terapeuta ocupacional).

[...] quando comecei, ainda no estágio... até hoje... o que mais me incomoda mesmo é essa questão do sofrimento (Ana, terapeuta ocupacional).

[...] o caso que mais me marcou [...] foi o C., adolescente, que já estava mais na fase final, e ele pegou um fungo raríssimo e estouraram feridas no corpo inteiro dele. [...] Foi uma coisa que me angustiava muito! Eu entrava e via aquele adolescente nesse estado... Com certeza, ele estava sentindo muita dor... [...] E, saber que eu, enquanto T.O., não tinha formas de auxiliar no manejo dessa dor tão intensa, porque a gente pode até ter umas técnicas de posicionamento e mesmo de distração, enquanto você está fazendo uma atividade, uma coisa que, às vezes, alivia... mas nada para uma dor tão intensa! [Ri] Então, me angustiou muito. [...] Foi o meu limite... (Ana, terapeuta ocupacional).

A enfermeira Eduarda mencionou, também, a realização de procedimentos invasivos como uma das dificuldades experimentadas em sua atuação profissional, apesar de ter conhecimento sobre a importância desses procedimentos para o restabelecimento da saúde da criança. A fala dessa profissional ressalta a ambivalência com que ela se depara ao aproximarse da necessidade de realização de um procedimento doloroso e, ao mesmo tempo, do sofrimento do jovem. Enfatiza que, em situações em que não consegue realizar esses procedimentos de forma imediata e bem sucedida, prolongando o sofrimento do paciente, tende a experimentar sentimentos de angústia, impotência e incapacidade.

[...] de uma maneira geral, cuidar de crianças é difícil. Você tem um envolvimento... Você, querendo ou não, tem que prestar algum cuidado ou realizar algum procedimento que vai causar dor, desconforto, incômodo. Então, isso para a gente também se torna um procedimento doloroso: saber que você precisa, para o bem-estar da criança, para a melhoria do estado geral dela, mas que isso a incomoda. [...] Por exemplo, é o caso de você ter que puncionar várias vezes, aí não consegue, aí tenta... mas se acontecer de duas, três vezes e você não conseguiu, então, vai causando mais estresse, mais angústia, vai te dando um sentimento de impotência, de incapacidade de fazer aquilo (Eduarda, enfermeira).

A assistente social Regina também contou sobre o quanto se sentia incomodada, no início de sua atuação neste contexto, ao imaginar os pacientes passando por procedimentos 
invasivos mas, diferentemente da enfermeira Eduarda, a compreensão sobre a importância desses procedimentos para o restabelecimento da saúde das crianças e adolescentes permitiu a ela atribuir novos sentidos a essas experiências, conseguindo, então, lidar melhor com essa questão.

[...] o que é mais doloroso são os procedimentos que são feitos com as crianças [...]. Mas, hoje, consigo enxergar que isso é importante, que faz parte do tratamento! (Regina, assistente social).

A assistente de enfermagem Clara revela que, devido ao fato de o tratamento para o câncer requerer, muitas vezes, a realização de procedimentos dolorosos, suas colegas enfermeiras e auxiliares de enfermagem não gostam de trabalhar com essa clientela. Assim, as colegas costumam requisitá-la para realizar esses procedimentos, já que ela demonstra não ter dificuldade para prestar esses cuidados.

[...] tem umas meninas que trabalham comigo que não suportam, não gostam de trabalhar com 'Onco', porque o tratamento é muito invasivo, muito sofrido! Mas eu gosto! (Clara, assistente de enfermagem).

[...] a única de nós que trabalhamos juntas aqui, que não tem problema para trabalhar com 'Onco' sou eu. Tanto as enfermeiras como as auxiliares, todas elas têm dificuldades! Assim, se eu 'tô' no plantão e tem procedimento assim... criança que não tá bem... mielograma ${ }^{9}$... elas preferem que eu faça, porque elas têm dificuldade, principalmente, se for criança muito pequena. Elas não gostam muito não... elas têm dificuldade (Clara, assistente de enfermagem).

O psicólogo Tadeu também mencionou algumas dificuldades que enfrenta em sua trajetória profissional neste contexto. Dentre elas, cita: o contato com famílias muito desestruturadas e com situações em que pacientes e familiares demonstram dificuldade de compreender o adoecimento, a despeito das tentativas realizadas para que se alcance uma compreensão adequada. Nessas ocasiões, o profissional relatou experimentar sentimentos de impotência e desânimo, pelo fato de não conseguir despertar, no outro, a emergência de significados favoráveis ao tratamento.

Às vezes, quando a família está muito desestruturada e está difícil de compreender o adoecimento, e eu faço esforço para facilitar a compreensão e a 'coisa' não acontece... (Tadeu, psicólogo).

\footnotetext{
${ }^{9}$ Exame realizado para avaliação da medula óssea, podendo ser utilizado para diagnóstico de determinadas neoplasias, como leucemias.
} 
Me sinto mais ‘tocado' quando entro em contato com uma família com uma história de abandono absurda e, às vezes, eu também perco o recurso diante disso! Sei lá, o que eu posso fazer? [...] São momentos em que me sinto impotente [...] São esses momentos que dá desânimo... (Tadeu, psicólogo).

A nutricionista Denise revelou que uma das dificuldades que enfrenta em sua atuação profissional está ligada a questões culturais e socioeconômicas de pacientes e familiares, por escaparem de seu controle, por despertarem em si, sentimentos de impotência e frustração e por representarem entraves ao desenvolvimento dos pacientes. Ela exemplificou que costuma ter mais dificuldades para cuidar dos pacientes com câncer, pelo fato de as mães nem sempre seguirem suas orientações com relação à alimentação dos filhos. Segundo ela, as mães de pacientes com câncer não costumam estabelecer limites a seus filhos, por significarem a doença como fatal, diferentemente do significado atribuído pelas mães de pacientes com outras enfermidades crônicas. Há, ainda, questões institucionais - carga horária extensa e atendimentos em diferentes clínicas - que fazem com que ela se sinta em dívida com seus pacientes: sente que não consegue se dedicar o suficiente, experimentando sentimentos de frustração em vários momentos. É necessário atentarmos para o fato de que essa profissional parece experimentar não só frustração, mas sentimento de culpa por não conseguir se dedicar tanto quanto gostaria aos seus pacientes. Outra dificuldade relatada por ela, como entrave para oferta de um cuidado de qualidade, diz respeito ao fato de seu trabalho não ter continuidade no ambulatório - ela explicou que, apesar de haver uma nutricionista responsável por orientar os pacientes no ambulatório, elas não se conhecem, o que as impedem de prestar uma assistência de forma contínua e baseada em condutas convergentes. A profissional ressaltou, também, que costuma se sentir mobilizada diante de situações que envolvem diagnóstico de recaída e definição de cuidados paliativos. Porém, contou que, após o choque inicial, consegue se restabelecer e sentir-se melhor.

[...] às vezes, é muito frustrante, porque a gente não consegue todos os objetivos! Na parte nutricional, a gente encontra vários empecilhos. Tem a questão cultural, a questão socioeconômica que está envolvida. Às vezes, a gente quer que a criança se desenvolva de uma forma e a criança se desenvolve de outra, tem outras vivências... Então, às vezes, fica um pouco frustrante (Denise, nutricionista).

A mãe de criança com câncer é a mãe que tenho maior dificuldade! Ela quer dar mais guloseimas, quer agradar mais a criança. A impressão que tenho é que elas veem a doença como uma doença fatal! Estão tratando, mas não acreditam plenamente no sucesso do tratamento. Com relação à parte nutricional, elas querem mesmo é satisfazer o desejo da criança [...] É diferente das outras clínicas em que atuo, como a 'cardio' e a 'gastro'... são 
mães que acreditam mais que aquele tratamento vai ter um sucesso (Denise, nutricionista).

Dificuldade eu sinto em relação à carga horária e às várias clínicas envolvidas [quarenta horas semanais na Pediatria, divididas entre Oncologia Pediátrica e outras clínicas]. Sinto que não dedico o tempo que gostaria de dedicar... que esses pacientes merecem. Às vezes, fico com essa sensação de frustração, de que podia ter colaborado mais, de que podia ter dado uma atenção mais especial, ter conseguido resolver mais questões... mas, aquela carga horária e o excesso de trabalho não me permitem. [...] Tem também uma dificuldade em relação ao meu trabalho não ter continuidade no ambulatório, porque atuo na enfermaria e há outro profissional que atua no ambulatório e, às vezes, as condutas são divergentes. Eu não conheço a profissional do ambulatório [risos], ela não é minha colega, porque não é contratada pelo hospital, mas por um grupo de apoio... Então, as condutas divergem, às vezes e, então, a gente encontra dificuldade (Denise, nutricionista).

[...] tem dias mais difíceis... um dia de diagnóstico de recaída, um dia em que uma criança vai entrar em cuidado paliativo! Nesse dia, saio um pouco mal... Mas, um dia depois, já consigo elaborar e fico bem (Denise, nutricionista).

Foi possível observar que os participantes vivenciam limites no cuidado que realizam e, diante disso, experimentam sentimentos de impotência, incapacidade, frustração e desânimo. Porém, por trás desses sentimentos, permanece velado o desejo onipotente dos profissionais de que o processo caminhe seguindo suas próprias referências, bem como a vontade que os mesmos sentem de controlar o incontrolável - a forma como os pacientes cuidam de si mesmos, compreendem a doença e lidam com o tratamento, assim como a resposta de cada organismo à medicação e a própria condição humana de finitude. A busca de controle empreendida por esses profissionais escancara o raciocínio paternalista que, em alguns momentos, parece permear as ações dos mesmos. Assim, deflagra-se o limite desses depoentes: cuidar do outro sem ter a garantia de que o "prescrevem” será seguido... O paciente é livre para assumir o próprio cuidado ao seu modo e isso frustra muito o desejo de controle e a onipotência desses profissionais.

Diferentemente de todos os entrevistados, que contaram sobre dificuldades experimentadas em seu contexto de atuação, a assistente de enfermagem Clara, revelou não sentir dificuldades, o que nos chama a atenção e pode revelar a tranquilidade e bem-estar com que essa profissional realiza seu trabalho, mas pode estar relacionado também com uma resistência para reconhecer e aceitar as próprias dificuldades.

[...] não tenho dificuldades por pior que eles [pacientes com câncer] estejam (Clara, assistente de enfermagem). 
Apesar das dificuldades enfrentadas, todos os participantes relataram experimentar satisfação e realização profissional na atuação em Oncologia Pediátrica, mostrando que encontram sentido no ofício por eles desempenhado.

[...] pessoalmente, me sinto completamente realizada! (Denise, nutricionista).

[...] hoje não tenho mais dúvida de que é isso que quero [...] Profissionalmente, estou realizada porque estou no trabalho que gosto! [...] É uma experiência muito válida... cada família, cada paciente é um caso, uma nova experiência (Regina, assistente social).

[...] minha vivência ao longo desses vinte e um anos é muito gratificante, porque me realizei profissionalmente! [...] Me realizei mesmo! Faço porque gosto... eu me dedico! (Regina, assistente social).

[...] a gente batalha bastante e eu acho que é motivador mais do que tudo! (Denise, nutricionista).

As assistentes sociais Regina e Natália comentaram sobre o quanto é gratificante poder estabelecer um vínculo com pacientes e familiares. Natália acrescentou, ainda, que a construção desse vínculo é facilitada pelo fato de o tratamento para o câncer ser, geralmente, longo.

[...] tem coisas boas também e isso é gratificante... esse vínculo que você cria com as famílias e com os pacientes! [...] esse é o retorno! (Regina, assistente social).

[...] como elas [as famílias] vão ficando nas nossas vidas, porque elas vão ficando aqui por um bom tempo, você vai podendo estar junto e perceber essa transformação da família, né... Isso é muito rico para mim (Natália, assistente social).

A nutricionista Denise nomeou esse vínculo construído com pacientes e familiares como uma amizade. Contou que esse laço tende a permanecer e que as mães costumam retornar ao hospital para rever os profissionais, mesmo em casos em que seus filhos faleceram ou estão fora de tratamento.

Eu estreito o laço com a criança, com a família, com a mãe! Quando acontece de a criança falecer, continuo tendo contato com a mãe... essa amizade perdura (Denise, nutricionista).

Como o tratamento é longo, elas [mães] criam vínculo com a equipe, com o hospital e sentem falta! Verbalizam que gostam de vir, gostam de matar a saudade... que sentem falta, apesar de terem passado aqui um tempo sofrido! (Denise, nutricionista). 
Alguns profissionais entrevistados revelaram satisfação pelo trabalho, em Oncologia Pediátrica, pela oportunidade de servir ao próximo e colaborar com o outro em um momento difícil, o que é proporcionado pelo vínculo construído com pacientes e familiares, mencionado anteriormente.

[...] não há dinheiro que pague [...] quando você consegue possibilitar que essa família transforme, apesar do sofrimento, algumas coisas na vida dela; que você está nesse processo, não que você esteja ensinando, mas elas [as famílias] conseguem, a partir dessa relação, disparar recursos para lidar e enfrentar a vida de um outro lugar, de uma forma diferente... [...] E, também, os direitos que você começa a ajudar as famílias a acessar, né... sair daquele lugar de que tudo é um favor e ajudar a lutar para conseguir esses direitos. E as famílias vêm para a gente e falam: 'Olha, fui atrás, batalhei... não deixei, lutei por aquilo e deu certo!’. Então, para mim, é o retorno maior que a gente tem (Natália, assistente social).

[...] me sinto confortável [...] você vê que, naquele momento difícil, a pessoa pôde contar com você e você pôde colaborar! (Regina, assistente social).

Percebo que a Medicina é, para mim, a forma de ajudar [ao próximo] e isso está sendo até hoje, em qualquer paciente, principalmente quando tem a doença maligna (Júlio, médico).

A terapeuta ocupacional Ana contou que costuma ser questionada por diferentes pessoas sobre o sentido de se trabalhar em um contexto de intenso sofrimento. Apesar das dificuldades que permeiam sua atuação, revelou que há algo maior que faz com que ela continue escolhendo esse trabalho: a atuação, nesse contexto, faz sentido para ela, a despeito dos desafios e dificuldades, pelo fato de permitir-lhe cuidar de pessoas que estão enfrentando situações de adoecimento, de restrições às possibilidades de seu existir. É possível pensar que sua possibilidade de cuidar do outro lhe faça sentido por oferecer momentos em que ela se sinta útil, diferentemente da impotência que sente ao se deparar com pacientes em intenso sofrimento físico e psíquico, que ela cita como uma das maiores dificuldades que permeiam sua atuação.

A gente vê que, para o senso comum, trabalhar com câncer é difícil e, mais ainda, quando se trata de criança com câncer! Então, assim, permeia no imaginário popular aí de que 'como assim você foi escolher trabalhar nesse lugar aí?’ [Risos] 'você não pode estar normal'. [...] tem tudo isso! Tem, mas apesar disso, tem algo maior (Ana, terapeuta ocupacional).

[...] permite que você cuide das pessoas num momento muito frágil, num momento que elas estão muito necessitadas de cuidado [...] é muito gratificante você saber que, de certa forma, você está conseguindo ajudar no enfrentamento daqueles momentos que são tão difíceis, tornando eles um pouco mais amenos ou conseguindo construir coisas, projetos de vida com o 
paciente num momento em que a morte ronda tanto... conseguir construir projetos de vida e momentos de vida, mesmo que não sejam projetos a longo prazo, mas momentos em que o paciente está inteiro ali, com você! Então, eu acho isso muito... legal! (Ana, terapeuta ocupacional).

Alguns participantes contaram que esses sentimentos de satisfação e realização profissional estão associados ao reconhecimento que recebem de pacientes e familiares pelo serviço prestado.

[...] não há dinheiro que pague, quando a pessoa vem te agradecer (Natália, assistente social).

[...] depois você vê os pais retornando na Unidade... um mês, um ano, dois anos, três anos, para agradecer... porque só conseguiu enfrentar aquela situação porque teve o nosso apoio nesse período (Eduarda, enfermeira).

A assistente de enfermagem Clara parece significar o carinho e a atenção recebidos por parte desses pacientes como reconhecimento pelo cuidado prestado por ela.

Tem alguns que, pelo tempo que estou aqui [aproximadamente trinta e dois anos], já casaram, já têm filho, mas eles ainda vêm aqui, e eles têm um carinho especial pela gente! (Clara, assistente de enfermagem).

Assim como a enfermeira Eduarda, a assistente de enfermagem Clara, a assistente social Natália e a nutricionista Denise, a assistente social Regina sente satisfação pelo reconhecimento e carinho que recebe dos pacientes. Porém, diz que desempenha suas funções sem se preocupar se terá ou não esse retorno pelo que faz, mas revela que esse retorno tende a aparecer posteriormente.

[...] você percebe, trabalhando nessa área, o carinho dos próprios pacientes, das famílias! [...] A gente faz sem pensar no retorno, sem pensar no futuramente, mas você vê que esse retorno vem mais tarde e que você fez alguma coisa de bom para aquela família... e que a gente conseguiu, naquele momento, naquela hora de sofrimento, dar um colo... naquele momento que ela mais precisou! (Regina, assistente de social).

O médico Júlio, assim como a assistente social Regina, também comentou que não espera esse reconhecimento por parte de pacientes e familiares, apesar de reconhecer o quanto é gratificante ser alvo de sentimentos de gratidão, os quais costumam ser demonstrados, muitas vezes, através de presentes. É possível perceber que não esperar esse reconhecimento funciona como um recurso para evitar a frustração ou a decepção. Vale destacar também que, assim como a assistente social Natália relatara anteriormente, para o médico Júlio, o tornar- 
se pai possibilitou-lhe se aproximar ainda mais dos pais de crianças com câncer, favorecendo sua empatia pelos mesmos.

[...] o segundo [conselho que o chefe da Hematologia lhe deu quando ele terminou a residência] era 'Nunca espere gratidão!'. Aquilo eu nunca esqueci e fui entender o que ele estava falando... Como assim, não espera? A gente tá tratando... vai, trata, tal e... quando você perde, morreu! Então, por mais que você tenha sido e foi... tratou direito... foi decente, foi amigo, acabou pra aquela pessoa! Eu tenho três filhos hoje, e eu sei o que é isso! E acabou, morreu! Então, quando vem a gratidão em vida ou depois que perde, é uma surpresa sempre boa para mim, porque me preparo para não ter e entendo não ter, mas quando tem, é legal! [...] tem paciente que não consegue vir aqui, uma vez a cada duas ou três semanas, sem trazer um presente (Júlio, médico).

Alguns participantes enfatizaram também a satisfação por acompanhar os momentos posteriores ao término do tratamento, o que evidencia o prazer que experimentam ao aproximarem-se da possibilidade de cura de seus pacientes.

Tem também os pacientes que estão no Ambulatório de Curados [Ambulatório de pacientes fora de tratamento que acontece todas as sextasfeiras no período da tarde] e que de sexta-feira, fico muito feliz! [...] Hoje, nós temos pacientes que estão com vinte e seis anos no Ambulatório de Curados e que chegam e falam: 'vim trazer meu filho para você conhecer!' (Regina, assistente social).

É gratificante, assim... principalmente quando o tratamento dá certo, né. Hoje, assim, é o dia que eu fico mais feliz, porque hoje é o dia dos curados! [...] Adoro esse ambulatório! Acho que... apesar de ter muita coisa sofrida, tem assim... como é que eu vou falar... tem sua... gratificação, compensação. Você vê que nem tudo o que você faz é em vão! [profissional se emociona e chora] (Clara, assistente de enfermagem).

Apesar da satisfação que experimenta diante do término do tratamento de seus pacientes, a assistente de enfermagem Clara demonstrou consciência da possibilidade da morte, já que menciona que nem todos os pacientes conseguem alcançar esse desejoso sucesso no tratamento e acabam evoluindo para o óbito.

[...] a gente fica muito feliz quando os pacientes terminam o tratamento com sucesso... essas coisas... mas, a gente sabe que nem tudo nessa vida é assim (Clara, assistente de enfermagem).

É que tem, assim... paciente que você vê... que ele chega relativamente bem e ou você vê ele se aflorar e sarar, ou você vê ele definhar até a morte (Clara, assistente de enfermagem). 
A enfermeira Eduarda revela que experimenta o término do tratamento de pacientes com sentimento de dever cumprido pelo cuidado prestado.

[...] ao mesmo tempo em que é doloroso, quando você vê o resultado final sente uma satisfação... teu dever foi cumprido (Eduarda, enfermeira).

A assistente social Natália atua apenas na enfermaria, por isso, possui pouco contato com pacientes que já finalizaram o tratamento. Ela revelou sentir satisfação quando tem oportunidade de rever pacientes que já terminaram seus tratamentos, por significar esses momentos como possibilidades de desfrutar com eles a situação de melhora e a possibilidade de cura, além de poder compartilhar com eles seus investimentos no futuro. É possível pensar na importância que tem, para essa profissional, a possibilidade de transcender o espaço de seu trabalho - enfermaria - para entrar em contato com pacientes que finalizaram seus tratamentos. Após o término do tratamento, essas pessoas começam a respirar “novos ares”, que oferecem um pouco mais de tranquilidade para que elas possam sonhar e fazer projetos para o futuro, e a participante parece se abastecer desses mesmos ares, dessa crença na possibilidade de cura desses jovens, para continuar exercendo seu cuidado junto àqueles pacientes que ainda estão em tratamento na enfermaria. Essa oportunidade parece funcionar como um recurso de enfrentamento, apesar de isso não ter sido explicitado no discurso da assistente social.

\begin{abstract}
Quando comecei a trabalhar aqui, teve uma mãe, a mãe da R. [...] Como a R. internava muito, então, assim, essa mãe me procurava muito e ela criou um vínculo muito forte comigo! E hoje, né, vira e mexe, essa mãe vem ao hospital e, sempre que ela vem, ela vem me visitar! Hoje, a filha está com dezoito anos, e eu encontrei com ela, na semana passada, lá no ambulatório. [...] então eu pude olhar o processo, né, de outra pessoa: antes de fazer o tratamento e hoje, com dezoito anos. Faz onze anos que ela tratou aqui, o tempo que estou aqui, praticamente! Então, isso favorece a olhar o processo da melhora, né... da cura, das possibilidades, porque como eu fico muito em enfermaria, eu não acompanho esses pacientes no ambulatório... Então, eu perco muito o foco! [...] Sempre pego a finitude, né, quando as crianças se vão! Então a R. foi uma experiência muito linda de olhar, né, desde que ela começou o tratamento e acompanhar esse processo até hoje! [...] Ver a R. hoje, moça, tirando carta, estudando, fazendo faculdade! [...] A morte aqui acontece muitas vezes... Então, neste aspecto, é bom olhar para isso, é uma alegria olhar que ela conseguiu, que a gente pôde participar deste processo e que ela está tocando a vida dela! (Natália, assistente social).
\end{abstract}

O médico Júlio parece experimentar, de uma forma diferente, o término do tratamento de seus pacientes. Para ele, não basta que os pacientes reconquistem a saúde. É necessário que façam escolhas saudáveis para que desfrutem dessa vida. Revelou sentir vergonha de dividir 
comigo que se sente completo e realizado, quando se depara com seus pacientes se tornando adultos bem-sucedidos. Contou de sua satisfação por ver seus pacientes ingressando na faculdade, por receber seus convites de casamento, mas, também, contou de sua decepção quando esses jovens optam por caminhos destrutivos.

[...] isso eu não entendia direito... Hoje, acho que entendo um pouco melhor: eu não dava muita bola no final do tratamento. [...] é que quando você termina o tratamento, parece que você não completou o seu trabalho. [...] parece que você ainda não fez o que você queria fazer [...] é como se... você ajudou todo mundo a vencer, você ajudou todo mundo a ter a vida... Então, parece que eu ficava esperando o que ia virar daquela vida. Então, me peguei uma vez chorando, há muitos anos, quando um moleque entrou aqui careca e falou que entrou na faculdade de veterinária! [...] fiquei emocionado! Aí que me toquei que... parece que... não valia a pena só curar, mas, assim... que ele fosse alguém na vida, que aquilo tivesse sentido! [...] a gente se emociona e tal... me ligam, me falam, eu pergunto! Como também teve um que foi pra droga, pegou HIV e aquilo me derrubou, me derrubou... assim, nem sei o que me deu! [...] fiquei 'p. da vida' com ele! Pegava ele aqui e falava: 'Não vou te bater porque não sou seu pai, porque se eu pudesse, eu ia te bater, moleque! Você não tem... noção!'[...] Mas, a maioria é legal... são os que mandam convites de casamento [...] tenho até vergonha de falar isso [risos] ... mas você fala: 'ah, valeu a pena!' Você entendeu? Claro que valeu a pena, tudo vale a pena, mas, na minha visão é... é ele virar alguma coisa, é ele ser alguma coisa... Então, eu vejo uns na USP, outros na UNESP, outros como bons profissionais... "Poxa", eu vejo... e, isso me deixa muito satisfeito! É onde eu me completo! (Júlio, médico).

É possível perceber na fala anterior do médico Júlio que, para ele, o sentido do seu trabalho, a sua realização profissional estão intimamente ligados à realização de seus pacientes. Porém, fica evidente que o participante significa a realização de seus pacientes, seguindo sua própria referência, em relação ao que considera ser a melhor maneira de desfrutar da saúde reconquistada. Sendo assim, nas ocasiões em que os desejos dele e as vontades dos pacientes convergem, ele sente-se satisfeito, porém, quando divergem e os pacientes optam por trilhar um caminho distinto daquele que o profissional julga mais adequado, a despeito de todo o seu esforço para cuidar da vida daquele paciente, o médico entra em contato com a frustração. O profissional demonstra dificuldade para lidar com situações que escapam ao seu controle como, por exemplo, o fato de o outro ser livre para realizar suas escolhas.

A assistente social Regina significou a adesão dos pacientes e familiares ao tratamento como um dos principais motivos de seu sentimento de realização profissional, um retorno pelo trabalho que realiza, um reconhecimento dos esforços da equipe para transmitir informações sobre a doença e sobre a importância de se envolver com o tratamento. 
E o que é mais gratificante... [...] o nível de abandono de tratamento é zero! Nós, enquanto equipe, conseguimos passar para a família o quanto é importante fazer o tratamento, mesmo com o sofrimento que o filho vai passar. [...] Então, é isso que me deixa assim [...] você trabalha e vê retorno! [...] a adesão ao tratamento é o que me deixa realizada, porque acho que a gente consegue passar uma tranquilidade para a família... a importância que é fazer o tratamento... (Regina, assistente social).

[...] se a gente, enquanto equipe, se não estivéssemos fazendo uma coisa boa, trabalhando bem, a gente não teria essa adesão de, praticamente, $100 \%$ ao tratamento (Regina, assistente social).

Alguns participantes revelaram satisfação, também, por poderem desfrutar de vivências no contexto de Oncologia Pediátrica que são significadas por eles como lições de vida e como formas de aprendizado profissional.

Tinha uma menininha [...] ela tinha leucemia [...] tinha três aninhos, mas tinha um amadurecimento impressionante! Ela tinha um envolvimento, uma relação com algumas pessoas, uma compreensão da doença, que me causava muita admiração por ela! [...] Infelizmente, essa doença recidivou e ela acabou evoluindo para morte. A gente brincava muito, a gente tinha muito contato! [...] Nunca mais esqueci essa menina! [...] nunca mais vi uma criança daquela forma. Achei que ela era muito nova para agir daquela maneira [...] Eu não tinha muito envolvimento... assim, embora já tivesse dois anos [trabalhando neste contexto], eu ainda não tinha aquela experiência de conversar mais... Eu tinha contato com ela, mas era diferente de hoje, que sei me aproximar melhor da família, conversar, buscar informação, tentar conhecer melhor aquele espaço e até mesmo, enfrentar melhor aquela situação. Então, foi mesmo uma lição! Foi um aprendizado! (Eduarda, enfermeira).

A nutricionista Denise e a assistente social Regina mencionaram ter adquirido um aprendizado associado à valorização da vida e ao redimensionamento dos problemas enfrentados no cotidiano. No discurso de Regina emerge também lições de fé e perseverança.

[...] a experiência que eles [pacientes] passam pra gente é motivadora! [...] sinto muita satisfação, sinto muito mais prazer do que sofrimento. Isso me ajuda, é um aprendizado: aprendo a não reclamar das coisas, porque tem as crianças nessas situações, as mães, as famílias envolvidas... são exemplos para mim de como existem situações difíceis na vida... Então, para de reclamar de uma coisa à toa! (Denise, nutricionista).

Você aprende a valorizar mais a vida e deixar, assim, de reclamar: 'Ai, hoje estou cansada'; 'Ai, isso está ruim!'. Você vê que tem pessoas que estão muito ruins, que o quadro está fechado, que estão fora de possibilidades terapêuticas, mas que acreditavam: 'Eu vou viver! Eu não vou morrer!' (Regina, assistente social). 
Já a fala da assistente social Natália revela a oportunidade de entrar em contato com a experiência de pessoas capazes de utilizar o próprio sofrimento para seu desenvolvimento, identificando e mobilizando recursos pessoais a despeito de estarem vivenciando uma situação adversa.

Isso é muito rico para mim... independente do valor financeiro, essa devolutiva que a família dá de ir transformando a vida, apesar do sofrimento e da dor! E quer queira, quer não, a gente também vai aprendendo. Às vezes, eu penso: 'Nossa, será que se eu estivesse no lugar dela eu iria dar conta desse jeito?’ (Natália, assistente social).

Alguns profissionais também revelaram satisfação pela oportunidade de atuar no HCFMRP-USP. O médico Júlio contou que, apesar de a atuação nessa instituição consumir muito de seu tempo, ele gosta do ambiente universitário pelo contato estabelecido com os estudantes e residentes e por poder colaborar para a formação dos mesmos, além de sentir que esse ambiente estimula seu aprimoramento constante.

[...] acho que gosto demais! [...] o HC me toma um tempo, que hoje... hoje? Não, há anos eu não teria! Mas, gosto demais daquilo lá, porque é uma extensão talvez do que a gente faz aqui [consultório] e eu gosto do ambiente universitário! Esse ambiente universitário... primeiro, ele te força muito com os alunos, com os residentes... a você sempre se manter atualizado, de ponta... e eu gosto muito desse contato! (Júlio, médico).

Para a terapeuta ocupacional Ana, seu sentimento de realização profissional não se restringe à atuação em Oncologia Pediátrica, mas, também, envolve a questão de atuar em uma instituição reconhecida e valorizada pela sociedade devido à qualidade do serviço oferecido. A satisfação também está relacionada à afinidade e à preferência que a profissional sente pela atuação da terapia ocupacional dentro do contexto hospitalar, em comparação com a atuação em outros contextos - para ela, é um local que permite oferecer um cuidado englobando diferentes enfoques, indo além da reabilitação dos pacientes.

[...] a gente 'carrega' um pouco: 'Nossa, tratamento no Hospital das Clínicas é bom, a gente consegue fazer bem, ajudar o paciente de alguma forma, né'... Então, fazer parte desta equipe também me dá prazer enquanto profissional, uma sensação de bem-estar profissional (Ana, terapeuta ocupacional).

[...] a T.O. tem as áreas de atuação [...] e a área que tenho mais afinidade é a da T.O. Hospitalar, que tenta englobar todos os aspectos no indivíduo hospitalizado, que perde o convívio lá fora... Há um rompimento com o cotidiano, ele se afasta dos papéis que tinha antes, se afasta do convívio com os outros, passa por dor, por procedimentos invasivos... várias questões difíceis! [...] e eu não gosto da saúde física, aquele negócio de você ficar 
fazendo manuseios, posicionamentos, coisas... físicas! Eu gosto mais da parte mental, da parte emocional e... eu acho que na 'Onco', a gente consegue reunir e não ficar só naquela coisa física, maçante, de exercícios, de repetições. [...] na 'Onco' a gente consegue reunir vários enfoques, várias abordagens e não ficar preso naquela 'coisa' de reabilitação (Ana, terapeuta ocupacional).

É possível perceber que, a despeito dos desafios vivenciados na prática de saúde, os entrevistados compreendem a relação de cuidado estabelecida com seus pacientes como sendo de "mão dupla", de forma que eles tocam e são tocados pelos pacientes, sendo todos beneficiados e transformados pelo encontro.

[...] a gente acaba se beneficiando dessa relação. É uma troca! A gente acaba participando deste processo e recebendo! Dessa forma, para mim é gratificante poder estar junto, poder estar acolhendo, poder estar... [suspiro] enfrentando essa luta! (Natália, assistente social).

\subsection{ATUAÇÃO EM EQUIPE: IMPORTÂNCIA E DESAFIOS}

Nas falas seguintes será possível perceber que, a maioria dos profissionais, ao tematizar a respeito da atuação por eles realizada, define como "trabalho em equipe” a tarefa que desempenham juntamente com os seus colegas. Mas, vale ressaltar que, dentre essa convergência de perspectivas, surgiram percepções variadas e, muitas delas diametralmente opostas que evidenciam singularidades na compreensão e significação do trabalho que eles realizam.

[...] não sou eu, enquanto assistente social, somos nós enquanto equipe! (Regina, assistente social).

A enfermeira Eduarda ressaltou a importância de um trabalho em equipe para prestar um serviço que atenda às necessidades de pacientes e familiares de forma completa. É possível pensar na frustração que essa participante experimenta ao se deparar com seus próprios limites, os limites da instituição e dos demais profissionais de saúde quando não conseguem ofertar esse cuidado que, na visão da enfermeira, é significado como "cuidado de qualidade”, um cuidado total, capaz de sanar todas essas necessidades. 
[...] esse [cuidado] completo, sanar as necessidades da criança de uma forma geral, a gente, sozinho, não consegue. Você precisa do outro para trabalhar junto com você [...] Então, você faz parte da equipe para tentar trabalhar, de uma maneira mais próxima possível, pensando na criança, pensando na individualidade da criança, dela e da família (Eduarda, enfermeira).

Para as assistentes sociais Regina e Natália, o serviço de Oncologia Pediátrica do HC conta com algumas especificidades - consideradas diferenciais em relação aos demais serviços do HCFMRP-USP - que favorecem uma atuação em equipe, entre elas: o envolvimento e a integração entre os profissionais, a abertura para uma atuação conjunta, a disponibilidade para refletir, questionar e repensar condutas e para atentar às necessidades de pacientes e familiares, além da busca pelo aprimoramento constante.

[...] acho que é uma equipe [da Oncologia Pediátrica] muito bem organizada do ponto de vista dos atendimentos, que se preocupa muito com os pacientes. Eu acho que, nesse aspecto, a 'Onco' tem um diferencial [...] Principalmente eu, que transito em várias clínicas por aqui, tenho a oportunidade de ver. Aqui, todo mundo participa da reunião com os mesmos cuidados, ou seja, os cuidados vão além de olhar para doença em si, mas há outros aspectos que a equipe trabalha, cuida e que vai além. [...] a equipe é assim... cada vez se preocupa em melhorar mais! Quando a gente percebe que tem alguma coisa que não está legal, a gente pensa, para. Acho que todo mundo se implica muito, se envolve muito e, talvez por isso, o trabalho da 'Onco', da equipe daqui, está nesse nível diferenciado mesmo e acho que a tendência é cada vez melhorar mais! A equipe é tudo para a gente poder... é... oferecer para o paciente, para a família, o que vai ajudar, o que é importante nesse momento onde a fragilidade se expõe, onde já é tão difícil, né, quando a doença vai transformando a vida e vai balançando...(Natália, assistente social).

A gente tem discussões, a gente também tem nossos momentos de conversas: 'Olha, vamos ver o que a gente pode fazer, o que a gente pode melhorar' (Regina, assistente social).

Se um profissional fala uma coisa e outro profissional fala outra, então, acaba criando uma confusão na cabeça da mãe. Então, o que a gente sempre retoma é a importância de os profissionais falarem sempre a mesma coisa e, por isso, a gente tem as reuniões para discutir todos os casos e todos os casos são levantados, desde o caso social, médico, nutricional, tudo! (Regina, assistente social).

Para alguns participantes, as reuniões de equipe que acontecem semanalmente, tanto na enfermaria como no ambulatório, também representam um diferencial desse serviço, contribuindo para a integração dos profissionais e para sanar dificuldades vivenciadas na prática. 
A 'Hemato', de certa forma, consegue [trabalhar em equipe]. Essas reuniões que têm de quarta-feira, que todo mundo [todos os profissionais de saúde ou, pelo menos, um profissional de cada especialidade] participa, é uma oportunidade [de realizar essa atuação em equipe]. Não são todas as clínicas que têm isso, então é um diferencial. Você consegue falar, chegar mais próximo daquele objetivo do tratamento da criança... da criança e da família. Não dá para pensar só nela sem levar em consideração a família (Eduarda, enfermeira).

[...] a gente tenta se entender. Acho que dificuldades, todo mundo tem; às vezes, a gente tem mais afinidade com um profissional, mas, de um modo geral, acho que a equipe dá conta, porque a gente fala entre si. [...] É claro que ninguém é perfeito, que temos nossas desavenças... mas, tudo é resolvido na reunião mesmo (Regina, assistente social).

A assistente social Natália acredita que as reuniões oferecem também uma oportunidade para que profissionais expressem as angústias que experimentam na atuação profissional.

[...] é interessante que, nas reuniões de equipe, as pessoas verbalizam suas angústias [...]. Acho que isso é muito lindo de olhar: 'Olha, não dei conta de entrar no quarto dessa criança' ou 'Olha, gente, é difícil lidar com a morte dessa criança'. [...] na 'Hemato' percebo que o pessoal se posiciona mesmo, fala muitas vezes na reunião, expressa sentimentos... e, acho isso muito importante! [...] não dá para não chorar algumas vezes, não dá pra não dizer que não 'tá' triste, não dá pra não dizer que está sensibilizado pela dor, principalmente quando tudo é muito coeso, né... Isso fica aparente e é rico... de uma forma saudável (Natália, assistente social).

Para o psicólogo Tadeu, a expressão de sentimentos e dificuldades pelos colegas não acontece de forma natural, mas de maneira velada, através das preocupações manifestadas, principalmente, nas reuniões multiprofissionais. Apesar dessa expressão não ser escancarada, para o psicólogo, ela é positiva, pois serve de amparo à sua atuação e reverte em promoção de saúde. Essa percepção demonstra a capacidade do próprio profissional de estar atento e aberto às vivências não só de pacientes e familiares, mas, também, às vivências de seus colegas de trabalho.

[...] veladamente ela [a equipe] fala, mas escancaradamente é mais difícil. Em reunião de equipe, se você pega o 'fiozinho', você percebe que as pessoas estão falando disso [de seus sentimentos, dificuldades] (Tadeu, psicólogo).

São nessas preocupações que aparecem os sentimentos [...] os sentimentos vão aflorando! Eles não são falados assim: tô triste, tô feliz... mas, só de sentir a expressão no profissional, pra mim, é positivo... positivo, porque sei que isso vai se reverter em promoção de saúde e também me ampara, ampara as minhas questões, as minhas dúvidas (Tadeu, psicólogo). 
É possível pensarmos, a partir dessas falas anteriores, que a reunião multiprofissional proporciona aos profissionais de saúde um espaço não só de integração de saberes técnicos, mas também de saberes pessoais e interpessoais. Trata-se de uma oportunidade para que os sentimentos possam ser expressos e reconhecidos, não sem dificuldade, mas favorecendo a integração da subjetividade ao trabalho que realizam.

A terapeuta ocupacional Ana, em consonância com as assistentes sociais Regina e Natália, percebe diferenciais no trabalho dos profissionais que compõe esse serviço, porém, ressalta que existem aspectos a serem melhorados.

[...] a equipe tem defeitos... pode melhorar... pode se ajudar... mas, ainda é muito melhor do que outros lugares (Ana, terapeuta ocupacional).

Além disso, a terapeuta ocupacional Ana, trouxe uma percepção diferente daquelas expressas pela enfermeira Eduarda, pelo psicólogo Tadeu e pelas assistentes sociais Regina e Natália, em relação aos momentos em que a equipe se reúne. Apesar de acreditar na importância do encontro entre os profissionais para que os mesmos possam expressar suas dificuldades, trocar informações, ajudar uns aos outros e buscar formas mais eficazes de exercer o cuidado, Ana percebe que seus colegas de trabalho apresentam uma resistência para abordar suas dificuldades, o que faz com que eles utilizem os momentos que possuem juntos, como as reuniões, apenas para discutirem questões ligadas às condutas com pacientes.

[...] acredito que ajudaria muito [um espaço para troca entre profissionais da equipe], tanto às pessoas, individualmente, quanto a todos, em forma de equipe, para um trabalho em conjunto, mais coletivo, entendendo melhor o porquê da atuação ser daquela forma e ter diferentes atuações dentro da equipe. [...] seria muito bom para essa discussão da equipe e também para discussões pessoais. Se está difícil para determinado profissional, talvez esteja difícil para os outros profissionais também e, talvez, falando sobre isso a gente pudesse tirar uma conduta comum... tirar mais força para conseguir intervir naquele caso (Ana, terapeuta ocupacional).

[...] a médica da equipe me procurou para falar que estava muito difícil lidar com um paciente, especificamente. Achei, assim, muito interessante... coisa que, até então, nunca tinha acontecido! [...] a gente conseguiu falar sobre o assunto! Mas foi um momento único, não é o padrão (Ana, terapeuta ocupacional).

[...] a equipe não é disposta a sentar e falar dos assuntos difíceis... as reuniões ficam mesmo para discussão de casos e voltadas para os pacientes. Não vejo a equipe disposta a resolver problemas internos e se ajudar neste sentido, pelo menos, multiprofissionalmente falando (Ana, terapeuta ocupacional). 
Já, para a nutricionista Denise, a atuação multiprofissional é mais viável no serviço Oncologia Pediátrica, pelo fato de os profissionais deste serviço serem mais abertos a essa prática multiprofissional e conseguirem respeitar a atuação de cada colega, permitindo liberdade para que todos desempenhem suas respectivas funções, sem interferências de outros profissionais. Ela percebe que seu trabalho é valorizado pelos colegas e sente-se segura para realizar seu papel dentro desse grupo. Enfatizou ainda que, entre todas as clínicas em que atua, sente-se mais à vontade para trabalhar na Oncologia Pediátrica.

A equipe da 'Onco' é a equipe que mais favorece o trabalho multiprofissional, entre todas as outras que atuo aqui no hospital. É onde temos mais liberdade para desempenhar nosso papel, pra discutir o caso, não ter interferência na nossa atuação. É onde sinto mais segurança de atuar e onde sinto que meu trabalho é importante, é valorizado... é onde me sinto mais à vontade para trabalhar! (Denise, nutricionista).

Cabe refletirmos sobre essa colocação anterior de Denise em que ela demonstra significar que uma prática multiprofissional em saúde requer que a perspectiva de cada profissional seja aceita e legitimada, sem questionamentos, pelos colegas. Porém, é interessante pensarmos que em uma atuação efetivamente integrada, interdisciplinar, a interferência deveria existir como forma de intercâmbio de conhecimentos entre profissionais de diferentes especialidades e, é justamente por isso, que essa influência se tornaria enriquecedora, pois permitiria transformar a forma individual com que cada profissional atua em prol de uma meta comum a todos. A ausência de interferência levaria a pensar em ausência de comunicação, atuação separada, segmentada e pouco compartilhada.

A assistente social Regina acredita que o fato de esse serviço contar com profissionais que caminham juntos há quinze anos é um elemento que contribui para que haja liberdade e entrosamento nesse convívio. Para ela, o entrosamento permite que os profissionais de saúde falem a mesma linguagem, evitando transmitir informações divergentes para familiares e pacientes.

[...] o que a gente procura fazer... e acho que é por isso que essa equipe deu certo e está dando certo... é falar a mesma linguagem. [...] Acho que enquanto equipe, a gente se sente muito à vontade porque, tirando os residentes, a gente é uma equipe em que estamos juntos há quinze anos! [...] Acho que o mais importante é isso mesmo: a gente estar falando a mesma coisa para a família, ter as mesmas ideias! (Regina, assistente social).

A colocação anterior da assistente social Regina evidencia que, para ela, a uniformidade de pensamentos e ações é reflexo da sintonia e da convergência entre os colegas 
de trabalho que convivem há bastante tempo. Dessa forma, a inserção do novo e do diferente parece romper com a estabilidade conquistada pelo grupo ao longo desses quinze anos, ameaçando tal uniformidade. Porém, é preciso pontuar que, embora a conduta uniforme revele sintonia e convergência, pode também ser responsável por fechamento, estagnação e rigidez perante as possibilidades de contribuições e mudanças advindas com a inserção de novos profissionais, como no caso de residentes e estagiários.

Diferentemente da percepção da assistente social Regina, a enfermeira Eduarda ressaltou que a quantidade de profissionais de diferentes especialidades envolvidos e o fato de eles, nem sempre, compartilharem as mesmas ideias são fatores que dificultam esse trabalho em equipe.

[A atuação em equipe] é um desafio, porque são muitas pessoas... essas pessoas pensam diferente e, às vezes, surgem alguns conflitos. [...] Então, tem que ser muito bem trabalhado! (Eduarda, enfermeira).

A gente ainda tem essa dificuldade com a equipe médica, por conta desse egocentrismo que eles têm... essa coisa que são eles que determinam. E, querendo ou não, o tratamento é direcionado a partir deles, as condutas são eles que tomam e... mas, para elas serem colocadas, ou não, em prática, precisa também da equipe concordar com algumas coisas... mas, ainda gira em torno da equipe médica (Eduarda, enfermeira).

[...] a gente está em um hospital universitário e isso leva a muitos erros. Às vezes, conseguir fazer o residente [...] entender que algumas coisas não são... não é aquilo que eles [residentes] estão pedindo, solicitando... é difícil. [...] O processo de comunicação ainda é uma dificuldade... eu não gosto quando as coisas são dadas assim: 'Isso é para ser feito, porque alguém mandou!'. Então, a gente entra em conflito (Eduarda, enfermeira).

É interessante notar, nas falas anteriores da enfermeira Eduarda que, segundo sua percepção, as discordâncias de perspectivas entre os profissionais não só é uma realidade, como culminam no exercício da autoridade e do poder pela equipe médica.

Vale destacar ainda que, apesar da percepção da enfermeira Eduarda ser diferente do olhar da assistente social Regina em relação ao comportamento dos profissionais dessa equipe - enquanto Regina não percebe divergência de pensamentos e atitudes, Eduarda os reconhece - ambas creditam à diferença de pensamentos e ações um obstáculo à atuação integrada.

Nessas falas anteriores, a enfermeira Eduarda menciona também a atuação em hospital universitário e as dificuldades de comunicação como outros entraves à atuação conjunta. 
Em consonância com a enfermeira Eduarda, a terapeuta ocupacional Ana também escancara os limites desses profissionais em termos de comunicação com os colegas de trabalho, ressaltando a existência de momentos marcados por silêncio, velamento, negação e falta de sintonia desses profissionais com as situações vivenciadas por eles no cotidiano. Além disso, aparece em seu discurso, a dificuldade dos profissionais de reconhecerem e lidarem com seus limites pessoais e profissionais.

Na semana passada, fui descobrir, pela mãe de uma paciente, que outra paciente tinha ido a óbito na Unidade de Emergência. E, [o falecimento] foi justamente de terça para quarta, sendo que a gente faz a reunião na quarta de manhã e... não se tocou neste assunto. Era uma paciente que estava sendo seguida há bastante tempo, uma adolescente com uma dor que eu nunca vi igual! $\mathrm{E}$ [...] mexeu muito com a equipe! Estava todo mundo muito angustiado por não saber o que fazer, porque eram urros de dor... tanto é que ela foi para U.E. [Unidade de Emergência] para tentar o controle da dor, sob sedação. E, ela foi a óbito e morreu o assunto... [risos], trocadilho malvado, mas é verdade. Você vê a dificuldade mesmo das pessoas de tocarem nos pontos falhos... não falhos assim, de erro médico, não, mas todo mundo tem um limite pessoal e de atuação e... é difícil! Ninguém é Deus... tem aquela coisa, assim de ser Deus, ser um herói, ser... principalmente para a equipe médica. Então, é difícil aceitar quando... quando não dá mais, né... talvez por isso, a ‘evitação’ de tocar no assunto (Ana, terapeuta ocupacional).

A terapeuta ocupacional Ana menciona também o ambiente físico como um desafio para uma atuação conjunta, pelo fato de as salas dos profissionais encontrarem-se dispersas em diferentes locais e andares do hospital, representando obstáculos a esse contato frequente e espontâneo.

[...] tenho pouco contato pessoal com as pessoas da equipe; um pouco, também, por minha sala ser aqui no quarto andar e, então, enquanto estou fazendo qualquer coisa que não seja o atendimento dos pacientes, fico aqui e não lá [Oncologia Pediátrica fica localizada no sétimo andar]. Então, acabo encontrando e convivendo pouco com as pessoas de lá e, então, acaba tendo poucos momentos de troca, por essa questão estrutural mesmo (Ana, terapeuta ocupacional).

Foi possível observar que, a importância do trabalho interdisciplinar não foi questionada pelos participantes, de forma que eles demonstraram acreditar nessa forma de trabalho como um caminho adequado para prestar uma assistência de qualidade. As divergências em relação à forma de considerar a integração e a desintegração dessa equipe derivam da forma com que cada depoente significa o trabalho interdisciplinar.

Outro aspecto importante a ser considerado é que, apesar do reconhecimento de que o serviço de Oncologia Pediátrica conta com diferenciais em relação aos demais serviços do 
HC, a atuação em equipe, segundo revelações de alguns participantes, parece não constituir uma realidade permanente, constante no cotidiano desses profissionais de saúde, a despeito dos desejos dos mesmos.

\subsection{CUIDANDO DE QUEM CUIDA: ESTRATÉGIAS PARA LIDAR COM A DOR DO OFÍCIO}

Para lidar com as dificuldades e desafios que permeiam a atuação em Oncologia Pediátrica, os profissionais entrevistados revelaram fazer uso de diferentes recursos de enfrentamento.

Com intuito de facilitar a compreensão do leitor, essa categoria foi dividida em seis itens: Limite de envolvimento, separação entre aspectos pessoais e profissionais e reconhecimento dos próprios limites; Experiência profissional e atenção aos próprios aspectos emocionais; Compartilhar dificuldades, dividir as dores, ter colegas de trabalho como suporte; Espiritualidade; Psicoterapia, atividades físicas e atividades manuais; Outros recursos: sentimento de dever cumprido; sentimento de capacitação; racionalização; bom humor.

6.5.1 LIMITE DE ENVOLVIMENTO, SEPARAÇÃO ENTRE ASPECTOS PESSOAIS E PROFISSIONAIS E RECONHECIMENTO DOS PRÓPRIOS LIMITES

Alguns profissionais mencionaram que buscam controlar a intensidade de envolvimento com pacientes e seus familiares, através da separação entre questões pessoais e profissionais, como estratégia de enfrentamento para que suas vidas pessoais não sejam prejudicadas e para evitar sofrimento excessivo.

[...] tenho um envolvimento muito grande com as crianças [...] Mas, consigo me controlar, na medida em que chego em casa... Às vezes, naquele dia, fico mais entristecida, mas não paro minhas atividades, não paro minhas atividades com minha filha, não deixo com que isso me impeça de ir a um teatro, a um cinema ou sair e ir para uma festa (Eduarda, enfermeira).

[...] não que não me envolva... me envolvo muito, mas consigo separar! [...] aos poucos, comecei a aprender separar (Regina, assistente social). 
[...] é um trabalho muito intenso mesmo, de conseguir separar e não levar isso lá para fora, porque ficar vivenciando isso também lá fora, vinte e quatro horas, é muito ruim! (Natália, assistente social).

[...] acho que, pelo tempo que estou aqui [aproximadamente trinta e dois anos], já consegui fazer essa separação [entre as questões pessoais e profissionais] (Clara, assistente de enfermagem).

[...] quando entro [no hospital], deixo meus problemas na porta e quando saio, deixo os daqui, aqui! Você tem que saber separar, porque se não souber... sofre... sofre muito! [...] Se não, você não vive... você tem que separar as coisas! (Clara, assistente de enfermagem).

[...] a gente sabe que tem um certo limite que você pode chegar [de envolvimento], mas que você não deve ultrapassar, porque aí... é muito sofrimento (Clara, assistente de enfermagem).

[...] sinto a dor do outro, mas é do outro, a dor não é minha! [...] é do outro e eu posso estar com o outro, mas não no lugar do outro e isso também me protege... me protege no sentido de que me deixa tranquilo para poder agir (Tadeu, psicólogo).

[...] sei separar as coisas: quando tem algum agravamento, algum falecimento... sofro, fico triste, mas consigo lidar bem (Denise, nutricionista).

Apesar de mencionar a importância de estabelecer um limite de envolvimento para com os pacientes e separar aspectos pessoais das questões profissionais, a assistente de enfermagem Clara, as assistentes sociais Regina e Natália, o médico Júlio, o psicólogo Tadeu e a terapeuta ocupacional Ana revelaram que nem sempre conseguem aplicar isso na prática. Eles parecem não conseguir conceber a si mesmos desvinculados de suas funções profissionais; trata-se de uma realidade à qual eles estão fundamentalmente relacionados.

[...] têm uns [pacientes] que não tem como você não ter um vínculo maior, apesar de você saber que se passar daquilo você sofre. Mas têm uns [pacientes] que não têm jeito... que são muito especiais, que não tem como deixar essa barreira e você ultrapassa ela (Clara, assistente de enfermagem).

Acho que nem tudo... a gente faz com muita clareza, assim: 'Olha, esse consigo, esse não!', porque é um ser humano que está doente, é uma família que está precisando (Regina, assistente social).

[...] o óbito para mim é [...] não tem como não sentir, não levar por um tempinho lá para fora; depois, você respira e retoma [a vida] de novo! (Natália, assistente social).

[...] quando vou embora, ainda sinto o reflexo desse óbito... fico mobilizada. Durante aquele dia, vou para outro trabalho que é em outro contexto, né... tento desvincular, mas não deixo de ficar mobilizada, ficar mais sensível... (Natália, assistente social).

[...] levo tristeza [para casa] (Júlio, médico). 
Para o psicólogo Tadeu, o fato de ter seus próprios problemas faz com que, fora do ambiente de trabalho, ele deixe as questões dos pacientes em segundo plano.

[...] não posso falar que me desligo, porque não consigo me desligar... mas eu tenho meus problemas, tenho minhas questões. Então, é... eu ponho em 'stand by', deixo em suspensão. Eu lembro, dá uma 'tristezinha'... (Tadeu, psicólogo).

A terapeuta ocupacional Ana pontuou que, apesar de nem sempre conseguir estabelecer essa separação, isso não repercute negativamente em sua vida pessoal.

[...] dependendo do caso que atendo, muitas vezes, eu levo comigo sim; falar que ficou aqui, é mentira! Eu levo para casa [...] Mas lembro, sei lá, antes de dormir, quando você deita na cama, lembro... não tem jeito! Assim, mas não é algo que me atrapalha a vida lá fora! Não interfere na minha vida pessoal... eu carrego comigo, mas a minha vida continua. Pelo menos, até hoje, não chegou a atrapalhar.

O psicólogo Tadeu acrescenta também que seu trabalho requer um respeito aos próprios limites para que ele consiga preservar sua vida pessoal e seus recursos. Para ele, trata-se de estar aberto ao outro, mas numa permeabilidade seletiva. Esse reconhecimento dos próprios limites e a diferenciação eu-outro permitem que ele busque possibilidades de atuação, mesmo diante das limitações existentes.

[...] tenho que saber que isso tem um limite para eu preservar minha vida, meus recursos, minha história. Minha história não é necessariamente a história do outro, mas posso usar a minha história para entender o outro, que pode ser meu colega ou a mãe, o pai, a avó, o adolescente, a criança (Tadeu, psicólogo).

[...] estar permeável é estar forte! E, estar permeável não é deixar passar tudo, é uma permeabilidade seletiva em que se deixa passar algumas coisas e outras não (Tadeu, psicólogo).

Tem dia que eu precisava atender um paciente, mas vejo que não vou dar mais conta, aí volto em outro horário, dou um jeito ou venho no dia que eu viria mesmo e vou estar melhor. Não adianta atender de qualquer forma, porque isso vai me fazer mal (Tadeu, psicólogo).

[...] prefiro, em vez de dar murro em ponto de faca, eu espero minha mão curar, minha mão estar mais forte para eu voltar a dar murro em ponto de faca; talvez a mão só esteja fraca naquele momento! (Tadeu, psicólogo).

Quando eu me vejo com meus limites, eu paro: ‘Ok, e o que eu posso fazer?' (Tadeu, psicólogo). 
A capacidade de reconhecer limites também é significada pelo psicólogo Tadeu como uma possibilidade de se ver como ser humano, o que pressupõe reconhecimento de impotência, de falhas, de emoções e de limites.

Eu tive histórias muito bacanas de dar... às vezes, a gente faz isso, né: o médico e o psicólogo vão comunicar que não há mais chance de cura, que agora é controle de dor e cuidado paliativo e, o paciente sair... e a médica [...] chorar, dizer que não queria ver a morte desse paciente! E eu acho uma delícia, porque a gente tira o jaleco de super-homem e passa a ser gente, gente que falha, gente que tem limites, gente que se emociona e isso faz parte... Isso faz parte do tratamento, isso faz parte do cuidado; essa é a essência do cuidado em Oncologia Pediátrica! (Tadeu, psicólogo).

\subsubsection{EXPERIÊNCIA PROFISSIONAL E ATENÇÃO AOS PRÓPRIOS ASPECTOS EMOCIONAIS}

Alguns profissionais entrevistados contaram que a experiência neste contexto de trabalho funciona como recurso e suporte para enfrentar situações difíceis.

Para a enfermeira Eduarda, sua experiência lhe possibilitou maior tranquilidade para expressar suas opiniões e para estabelecer relacionamentos mais próximos com pacientes e familiares, além de contribuir para o reconhecimento e a correção de falhas.

[...] hoje, que sei me aproximar melhor da família, conversar, buscar informação, tentar conhecer melhor aquele espaço e, até mesmo, enfrentar melhor aquela situação (Eduarda, enfermeira).

Você não tem medo de tomar atitudes, não tem medo de se posicionar em algumas coisas [...] Eu consigo ser aberta com a família [...] consigo fazer isso com mais segurança e até me aproximar mais dos pais. Em nenhum momento fugi de alguma situação, por mais difícil que ela fosse. [...] mas, a experiência e, talvez, as próprias vivências, vão te mostrando caminhos a serem seguidos e vão te corrigindo algumas falhas! (Eduarda, enfermeira).

A assistente de enfermagem Clara revelou que quando começou a trabalhar, neste contexto, sofria mais, porém, acredita que com o passar do tempo, foi desenvolvendo mecanismos defensivos para lidar com situações que antes eram consideradas difíceis.

[...] eu trabalho com eles, bem dizer, a minha vida inteira de serviço aqui [...] logo que eu comecei a trabalhar aqui [há aproximadamente trinta e dois anos] eu sofria demais! Aí, eu não sei... acho que o próprio organismo cria uma... uma defesa, né?! (Clara, assistente de enfermagem).

Graças a Deus, aprendi a conviver e a lidar com eles [pacientes com câncer] (Clara, assistente de enfermagem). 
Para o médico Júlio, a experiência de trinta anos trabalhando nessa área lhe permitiu aprimorar e oferecer uma assistência de melhor qualidade: passou a ser mais sensível à dor do outro, não assumindo uma postura de naturalização, como fazia antes, e passou a se envolver de forma mais profunda com seus pacientes e familiares.

Tudo, conforme você vai vivendo, muda... muda, sim! E o que mudou, ou que tenho tentado mudar, é para melhor [...] A gente quando forma, não sei se tem a ver com o que passei na minha vida também, de ter perdido os pais, de ter lutado relativamente sozinho... [...] eu fiquei meio como... você fica meio ... não é tão... sensível, vamos dizer assim! Então, para você, enfrentar aquilo que a mãe [da criança com câncer] está passando era, no passado, uma coisa muito normal [...] Eu não vivia tão fortemente como vivo os últimos anos, ou seja, estou me envolvendo muito mais, atualmente, do que no passado! (Júlio, médico).

Para a assistente social Regina e para a assistente de enfermagem Clara, a experiência adquirida neste contexto de atuação permitiu que elas aprendessem a separar questões pessoais e profissionais, como forma de evitar sofrimento excessivo.

Quando comecei, o envolvimento era maior [...] aos poucos, comecei a aprender separar (Regina, assistente social).

[...] pelo tempo que estou aqui [aproximadamente trinta e dois anos], já consegui fazer essa separação [entre as questões pessoais e profissionais] (Clara, assistente de enfermagem).

Para a assistente social Natália, a experiência nesse contexto lhe proporcionou aprendizado e amadurecimento. Ela relembrou que, em sua formação acadêmica, recebeu conselhos para que não chorasse diante dos pacientes, o que fez com que, no início da sua atuação, ela resistisse à manifestação de seus sentimentos. Mas, hoje, ela permite-se expressar seus sentimentos a pacientes e familiares.

[...] quando a gente está estudando, há uma construção bem acadêmica que diz: 'Não chore!', mas quando você vai para a prática, no começo, você fica brigando muito, como se fosse uma camisa de força... Mas, na verdade, com o tempo, você vai amadurecendo e vendo que dá para estar junto, sem perder seu objetivo, seu aspecto profissional... [...] Eu percebo, na minha experiência, que pude olhar para isso e foi onde comecei a me permitir, né. Tem momentos que posso chorar, né, que não vou conseguir me segurar! Quando eu der conta, tudo bem, mas às vezes, não precisa! (Natália, assistente social).

Além disso, para a assistente social Natália, a experiência de onze anos trabalhando neste contexto, permitiu-lhe ressignificar a morte, aceitando-a como parte da existência. Para 
ela, essa ressignificação não anula o sofrimento, mas favorece a aceitação. Apesar da dificuldade relatada, anteriormente, de lidar com o óbito de seus pacientes, ela demonstrou capacidade de lidar com essa circunstância, já que consegue entrar em contato com o sofrimento, mas sem ser tomada por ele a ponto de perder sua capacidade de mobilizar recursos essenciais para ao cuidado aos familiares enlutados e aos demais pacientes em tratamento.

[...] acho que conviver com essa realidade, como eu te disse, há onze anos aqui, você vai... você vai aprendendo a olhar de outro lugar para algo que te faz sofrer. Não que você não sofra, mas é como se a morte fosse construída na minha vivência, na minha vida hoje, como algo que faz parte da vida mesmo, que vai acontecer... mas, não que seja fácil. Acho que, talvez, a aceitação desse processo... eu estou internalizando mais. Acho que esse aprendizado, essa vivência contribuiu muito! (Natália, assistente social).

[...] eu digo, em relação à minha experiência... não que eu não sofra, não que eu não sinta, mas aprendi a lidar com ela [a morte], a aceitá-la um pouco mais (Natália, assistente social).

A assistente social Natália acrescentou, ainda, que a experiência em Oncologia Pediátrica possibilitou a ela aprender a atentar aos próprios aspectos emocionais como forma de buscar um equilíbrio interno, de cuidar-se e de preservar a qualidade de seus atendimentos.

[...] a gente também precisa estar atento aos aspectos emocionais que vão se desenvolvendo nesse processo de estar junto com essas crianças [...] a gente, enquanto profissional, tem que também ter um cuidado com a gente neste aspecto, porque acaba refletindo também nos atendimentos, por mais que a gente não queira, né... Então, equilibrar essas emoções, acho que para mim é algo que aprendi muito, estando aqui ao longo desses onze anos. Cuidar desse lado também é, sim, muito importante (Natália, assistente social).

O psicólogo Tadeu também comentou sobre a importância dessa atenção e da compreensão dos próprios sentimentos como sendo algo essencial para mobilizar recursos eficazes para lidar com essas sensações.

Eu sou muito fiel aos meus pensamentos e aos meus sentimentos e tento ver o que é que me tocou [...] Então, ok, vai me tocar e me tocou, mas em que? Isso tem a ver com questões minhas, com questões de empatia? Eu sempre tento fazer essa diferenciação, sempre fazendo isso para mobilizar recursos: o que eu posso fazer com esse meu sentimento? (Tadeu, psicólogo). 


\subsubsection{COMPARTILHAR DIFICULDADES, DIVIDIR AS DORES, TER COLEGAS DE TRABALHO COMO} SUPORTE

Alguns profissionais pontuaram que utilizam a troca de experiências entre os colegas como forma de auxiliar o enfrentamento das dificuldades que vivenciam no contexto profissional.

A enfermeira Eduarda mencionou a importância de ter um espaço junto aos próprios colegas da equipe de enfermagem para dialogar, discutir e compartilhar experiências como forma de suporte para lidar com situações difíceis. Revelou que esses momentos acontecem tanto de maneira informal, através de conversas no corredor como, também, formalmente, uma vez por mês, em um grupo conduzido por uma psiquiatra. Os profissionais da equipe de enfermagem e a psiquiatra responsável pelo grupo, percebendo as próprias demandas e as demandas dos colegas, criaram esse momento em que os profissionais interessados têm a oportunidade de dividir suas histórias e compartilhar seus sentimentos, medos e dificuldades.

[...] nós, enfermeiras e alguns auxiliares que ficam lá [na enfermaria] com mais frequência, sempre que possível, assim... de uma forma mais indireta, no corredor, no momento de maior tranquilidade, a gente está sempre discutindo e tentando compartilhar essa experiência, como foi difícil para um ou para outro (Eduarda, enfermeira).

A gente tem aqui um grupo, que acontece uma vez por mês com uma psiquiatra. Ela fica aqui uma hora e, nessa uma hora, os profissionais [da equipe de enfermagem] que desejam participar, têm a chance de poder dividir suas histórias, suas angústias [...] Isso ajuda, embora seja uma vez só por mês, mas ajuda... é um momento que você pode chorar, você pode dividir... e você vê que aquilo é natural (Eduarda, enfermeira).

O psicólogo Tadeu revelou que, em momentos difíceis em que é tomado por sentimentos de desânimo e impotência, busca apoio junto à própria equipe, que o ajuda a dar prosseguimento a seu trabalho. Ele significa esses momentos de troca com profissionais da equipe como uma possibilidade de se tranquilizar, de perceber que os colegas também encontram dificuldades na prestação da assistência, de sentir segurança e respaldo por parte dessa equipe, além de acreditar ser essa uma oportunidade de construir, junto com os colegas, formas mais eficazes de cuidar de cada paciente.

Me sinto mais tocado quando entro em contato com uma família com uma história de abandono absurda e, às vezes, eu também perco o recurso diante disso! 'Sei lá'... o que eu posso fazer? E então, eu vou conversar com a 
assistente social, primeiro, e ver o que ela já está fazendo para eu fazer também e completar o trabalho partindo de algum ponto. São momentos em que me sinto impotente (Tadeu, psicólogo).

[...] eu sempre fui de cavar espaço. Então, quando eu não estou bem, eu procuro, converso com o médico, converso com o residente (Tadeu, psicólogo).

[...] esses momentos de encontro com os outros profissionais é um momento de relaxar, de ver que o outro também está passando por dificuldades [...]. Esses encontros vão propiciar que eu fique mais tranquilo, que eu tenha mais segurança, mais respaldo de outros profissionais e que a gente consiga pensar formas diferentes de cuidar daquela pessoa (Tadeu, psicólogo).

Para a assistente social Natália, o contato com outros profissionais de saúde lhe proporcionou aprendizado e amadurecimento. Ela exemplificou que, através dessa troca, aprendeu a soltar-se mais nos atendimentos, permitindo expressar seus sentimentos.

Eu aprendi até a poder soltar um pouco esse lado [permitir-se chorar junto a familiares enlutados], olhando alguns profissionais que faziam isso no momento do óbito, né, que choravam... a enfermagem compartilhava (Natália, assistente social).

Outros participantes relataram utilizar a troca com seus próprios familiares como forma de apoio e como oportunidade para compartilhar suas dificuldades.

[...] levo tristeza [para casa]... comento com minha mulher, tudo... (Júlio, médico).

[...] comento com a minha mãe... coitada! [risos], e ela sempre escuta os casos piores e depois, fica até perguntando [...] [Risos] Ela compartilha! (Ana, terapeuta ocupacional).

A terapeuta ocupacional Ana revelou que não conta com nenhuma forma de apoio que possa auxiliá-la a enfrentar as dificuldades que permeiam a atuação em Oncologia Pediátrica, apesar de sentir necessidade de poder contar com um profissional para poder dividir suas angústias e sentir-se compreendida. Foi possível perceber que a profissional significa, como forma de suporte, apenas acompanhamentos formais como, por exemplo, atendimento psicológico. Apesar dos significados que atribui ao cuidado ideal para si, mencionando não estar tendo nenhuma fonte de suporte formal, ela possui um movimento de se ajudar, por exemplo, através da ventilação de sentimentos, que lhe permite buscar apoio de outras pessoas para compartilhar seus sentimentos, para desabafar e elaborar essas questões. 
[...] atualmente, não tenho nenhuma forma de apoio, mas acho essencial! Muito necessário seria mesmo que eu tivesse um acompanhamento terapêutico mesmo, meu, pessoal, mas, infelizmente, nesse momento, não tô tendo. E sinto falta porque, às vezes, você quer falar com alguém, alguém que saiba o que você está sentindo, alguém que te ajude a passar por isso [...]. Então, fica muito na ventilação... sai dali, conversa com alguém, desabafa e elabora sozinha [risos], porque... vai fazer o quê? Mas, acho muito importante que tivesse esse apoio (Ana, terapeuta ocupacional).

\subsubsection{ESPIRITUALIDADE}

Alguns profissionais contaram que a espiritualidade 'funciona' como uma ferramenta que os auxilia a enfrentar as dificuldades experimentadas na atuação profissional. Eles parecem buscar apoio e força no sagrado.

Para a assistente social Natália, a nutricionista Denise e a enfermeira Eduarda, a espiritualidade contribui para a compreensão, aceitação e elaboração de situações dolorosas que enfrentam ao longo de seu percurso profissional. Elas fazem uso de suas crenças como forma de atribuir novos sentidos aos sofrimentos vivenciados por seus pacientes e para ressignificar a morte deles.

Para a assistente social Natália e para a nutricionista Denise, a espiritualidade permite que elas encarem a morte como algo natural, inerente à existência humana. Além disso, contribui para que elas não paralisem diante dos obstáculos, conseguindo buscar formas possíveis de exercer o cuidado, mesmo diante das dificuldades.

[...] sou espírita kardecista. Acredito em reencarnação; acredito que ninguém passa por nada sem que tenha sido determinado, provocado. Muitas pessoas perguntam: 'Como você consegue lidar bem com uma criança que está com câncer?’; ‘É tão revoltante! Como Deus deixa uma criança ter câncer?’. Mas eu já vejo essa criança não como uma criança, mas como um espírito que já teve várias encarnações, que passou por várias experiências para ter que passar por isso, e que tem a família envolvida nisso também. Então, eu tenho o meu papel de ajudar aquele espírito a passar por essa situação e que, o que ele vai viver daquilo, é para evolução dele. Se ele chegar a falecer, é uma coisa que era para ser assim. É isso que me consola (Denise, nutricionista).

Tenho uma questão espiritual que me ajuda a elaborar e aceitar isso [agravamento e/ou falecimento] como algo que está ali e pode acontecer (Denise, nutricionista). 
[...] a espiritualidade [...] é outro recurso que me ajuda, né. [...] me ajuda bastante a enfrentar e a entender que a morte é realmente algo... que a única certeza que nós temos, na vida, é a morte mesmo! Acho que isso foi me ajudando a ficar, vamos dizer, mais tranquila, para quando eu tiver que dar suporte e apoio, eu consiga disparar esse recurso interno para que eu possa diluir isso no atendimento... para que eu possa conseguir, mesmo que venha o choro (Natália, assistente social).

A enfermeira Eduarda crê que os pacientes falecidos tornam-se anjos da guarda que intervêm na Terra por ela e pelos demais profissionais de saúde atuantes no hospital. Ela acredita que esses anjos proporcionam tranquilidade e sucesso em seu trabalho e parece significá-los como guias e acompanhantes de sua trajetória profissional.

Algumas crianças nossas se transformam em anjos da guarda. Tem hora que tenho a sensação de que parece que eles estão aqui te iluminando... E, pensar que eles viram anjos da guarda ameniza um pouco, porque é difícil entender porque eles têm que passar por isso (Eduarda, enfermeira).

[...] nestes momentos [realização de procedimentos dolorosos], respiro e tento fazer uma conexão entre o meu anjo da guarda e o anjo da guarda da criança, para que traga tranquilidade, para que eu tenha sucesso naquilo que vou fazer. Não sei se acreditar nisso traz mesmo a tranquilidade, mas aí o procedimento dá certo! Então, independente da religião da criança, porque é uma coisa minha... às vezes, até falo para a mãe: 'Não sei de que religião você é, se você acredita em anjo da guarda... mas vou chamar o meu para ele me ajudar neste procedimento' (Eduarda, enfermeira).

A fé aparece, novamente, no discurso da enfermeira Eduarda, ao relatar o conforto proporcionado pela intervenção de um padre em uma situação em que a equipe de saúde estava enfrentando momentos difíceis. A presença deste padre e suas colocações permitiram que ela resgatasse o significado que atribui à sua profissão, significado que faz com que ela continue escolhendo ser enfermeira de pacientes com câncer, por sentir que vale a pena, que faz sentido, apesar dos sofrimentos que permeiam seu ofício.

[...] nesta sexta-feira, aparece um padre aqui, do nada [...] por que esse padre que ia para outro lugar, veio aparecer aqui? Assim, [...] talvez a gente estava precisando! [...] e aí ele [o padre] te fala, que na percepção dele, os profissionais de saúde são dedos de Deus... é a forma com que Deus consegue atingir as pessoas. E aí, você fala: 'Compensa eu continuar nessa luta, nessa batalha!' (Eduarda, enfermeira). 


\subsubsection{PSICOTERAPIA, ATIVIDADES FÍSICAS E ATIVIDADES MANUAIS}

Alguns participantes mencionaram psicoterapia, atividades físicas e atividades manuais como recursos para descarregar tensões e reabastecer energias no período em que não estão trabalhando no hospital.

[...] fora daqui, tenho outras atividades [...] fora daqui, é pra descarregar... faço atividade física, faço trabalho manual, pinto, bordo! (Clara, assistente de enfermagem).

[...] me cuido, vou fazer exercício, vou fazer caminhada, vou nadar... também faço terapia... discuto (Tadeu, psicólogo).

6.5.6 OUTROS RECURSOS: SENTIMENTO DE DEVER CUMPRIDO; SENTIMENTO DE CAPACITAÇÃO; RACIONALIZAÇÃO; BOM HUMOR

A assistente de enfermagem Clara contou que faz uso de outro recurso para enfrentar as dificuldades e os sofrimentos inerentes à sua atuação profissional: experimenta um sentimento de dever cumprido pelo trabalho realizado e por oferecer o cuidado necessário e possível aos pacientes. Segundo ela, o sentimento de ter cumprido o que lhe cabia realizar faz com que ela não se sinta culpada, não se sinta em dívida com pacientes e seus familiares.

[...] quando saio daqui, sei que o que eu tinha para fazer, eu fiz! Até quando eles vão a óbito, sei que o que eu pude fazer por eles, eu fiz! Então, não tenho assim... não tenho peso na consciência... dor na consciência (Clara, assistente de enfermagem).

Vale relembrar que, diferentemente da assistente de enfermagem Clara, a nutricionista Denise costuma sentir-se em débito com seus pacientes.

Sinto que não dedico o tempo que gostaria de dedicar... que esses pacientes merecem. Às vezes, fico com essa sensação de frustração, de que podia ter colaborado mais, de que podia ter dado uma atenção mais especial, ter conseguido resolver mais questões... Mas aquela carga horária e o excesso de trabalho não me permitem (Denise, nutricionista). 
A nutricionista Denise demonstrou confiança em relação à sua capacidade de desempenhar sua função, o que pode ser considerado um fator que lhe permite enfrentar as dificuldades inerentes à sua atuação com maior segurança e tranquilidade.

[...] me sinto muito forte para lidar com essas crianças [...] e sei que consigo passar coisas boas para elas, além da questão profissional de nutricionista! (Denise, nutricionista).

O médico Júlio faz uso da racionalização para conseguir lidar com a morte de seus pacientes - esforça-se para encarar a situação como uma experiência inerente à vida e, a partir disso, tende a seguir em frente e continuar sua própria caminhada.

[...] levo tristeza [para casa]... mas, pouco tempo depois, você racionaliza! Perdeu... faz parte da vida e tudo... e você toca o barco! (Júlio, médico).

O médico Júlio acredita também, que seu jeito de ser influencia diretamente na forma com que ele cuida de pacientes com câncer. Ele pensa que o fato de ser brincalhão lhe permite criar um clima mais leve em um contexto de tratamento que é tão penoso.

[...] sou brincalhão [...] Brinco com todo mundo, com as famílias, com as crianças e tal! [...] acho que a coisa é muito pesada para a criança, para a família... então, se não tiver um ambiente ... amistoso...! (Júlio, médico).

Foi possível perceber que os participantes procuram desenvolver recursos de enfrentamento como forma de se adaptarem ao contexto de trabalho em saúde. Porém, esse movimento parece, na maioria das vezes, solitário, com raras exceções em que eles compartilham suas dificuldades e buscam apoio junto aos colegas. Essa compreensão de solidão parece ampliar-se diante de sentimentos de desamparo experienciados pelos profissionais em relação à instituição hospitalar em que atuam.

O psicólogo Tadeu e a enfermeira Eduarda ressaltam que, mesmo diante das dificuldades que permeiam a atuação em hospitais, a instituição em que trabalham não demonstra preocupações para com seus próprios profissionais.

[...] o hospital não está nem aí para seus funcionários, desde a tia da faxina até o médico professor doutor! (Tadeu, psicólogo).

A gente não tem o apoio do hospital na tentativa de amenizar o sofrimento que o profissional tem na prestação do cuidado [...] o hospital é uma instituição grande, mas peca muito nesse apoio, no acompanhamento do profissional (Eduarda, enfermeira). 
A assistente de enfermagem Clara alerta sobre a necessidade de suas colegas de profissão de receber algum tipo de apoio e ressalta, inclusive, apoio psicológico, pois segundo ela, a maioria delas, principalmente as novatas, tende a recorrer à medicação para suportar conviver com situações consideradas difíceis. Vale destacar que a profissional mencionou apenas as colegas como necessitadas de algum tipo de apoio, enfatizando, ainda, a importância desse cuidado aos profissionais novatos. Ela não se inclui entre as profissionais que precisam desse suporte, o que permite pensar que sua experiência profissional de mais de trinta anos atuando junto a essa clientela, funciona como recurso para enfrentar as dificuldades na trajetória profissional, mas, também, pode evidenciar uma dificuldade da própria profissional de se reconhecer como vulnerável. Além disso, quanto ao movimento que as colegas de Clara fazem de buscar na medicação o caminho para lidar com as dificuldades que enfrentam no contexto profissional, pode ser considerado uma busca por resultados rápidos.

As meninas, principalmente as novas, quando começam aqui, elas acabam indo pro médico, pedindo medicação, entendeu? Então, eu acho que tem muitas que têm necessidade [de alguma forma de apoio] (Clara, assistente de enfermagem).

A enfermeira Eduarda e o psicólogo Tadeu ressaltaram a importância do cuidado aos profissionais de saúde como medida essencial para a prevenção da saúde mental dos mesmos.

Não precisa esperar que o profissional adoeça para olhar para ele; tem que prevenir para evitar o que poderia levar a uma doença mental ou psiquiátrica em função do desgaste que ele [o profissional] tem, porque o desgaste é evidente (Eduarda, enfermeira).

A instituição precisa entender que trabalha com gente, trabalha atendendo gente, mas que seus funcionários também são gente, né?! São pessoas que trabalham lá e que também têm demandas. A instituição é perversa, extremamente perversa! (Tadeu, psicólogo).

Para o psicólogo Tadeu e para terapeuta ocupacional Ana, o cuidado aos próprios profissionais exige uma estrutura adequada, organização de uma rotina de atendimentos e contratação de equipes paralelas para cuidar dos funcionários.

[...] acho que precisam criar formas, mas formas mesmo! Não assim: 'olha tem um grupo ali pra discutir'... não! Você, de tal hora a tal hora, você vai estar ali, porque a gente vai organizar pra que você esteja ali sem ter que voltar para enfermaria e isso faz parte de seu trabalho: fazer parte daquele 
grupo, seja psicoterapêutico, seja de ginástica laboral, seja lá o que for! (Tadeu, psicólogo).

[...] precisa contratar uma equipe paralela para atender a equipe, não tem jeito! E precisa criar, tipo... hoje, das seis às sete horas não tem banho, hoje será às oito horas e dar subsídios para o profissional se sustentar e sustentar essa posição de cuidado! Se não, não acontece! (Tadeu, psicólogo).

Acredito que os grupos se esvaziam, porque 'preciso atender trinta e nove pacientes... Então, não vou!'. Eu também não iria, né! E não adianta... tem que ter começo, meio e fim, não pode ser 'ad eternum'! A gente precisa, o hospital precisa! (Tadeu, psicólogo).

ter um horário e um supervisor externo, alguém que venha para esse intuito, uma reunião especificamente para isso... (Ana, terapeuta ocupacional).

O psicólogo Tadeu acredita que, pelo fato de a instituição hospitalar em que trabalha não demonstrar ações voltadas para o cuidado de seus funcionários, cabe aos próprios profissionais colaborarem para a construção desse espaço de cuidado, assumindo uma postura mais ativa, em vez de se colocarem em uma postura passiva de ficar à espera de decisões da instituição. Segundo o participante, já existem esforços por parte dos seus próprios colegas, para criar espaços informais de apoio e troca.

E, fora isso, é um trabalho de cada profissional se inteirar com o outro, se não a gente fica só esperando a posição de fora. Acho que eu, enquanto psicólogo, o que eu posso fazer? E o médico? [...] não adianta esperar só o hospital resolver... que eu vou fazer ioga e vai resolver (Tadeu, psicólogo).

[...] a equipe, hoje, faz alguns esforços de criar esse espaço, como na reunião clínica, no corredor, na reunião na salinha... algo que é muito próprio da Oncologia Pediátrica! [...] É bem informal, mas acho que é uma forma que vale a pena... mas, acho que a instituição precisa criar um espaço para essas situações, que sejam protetoras mesmo! (Tadeu, psicólogo).

A enfermeira Eduarda também relatou que, frente à ausência de um movimento do próprio hospital visando a prestar um cuidado aos seus funcionários, a própria equipe de enfermagem criou um momento de cuidado para seus profissionais. Ela revelou, porém, que há entraves institucionais que dificultam a adesão dos seus colegas, entre eles, a rotina de trabalho.

A gente tem aqui um grupo, que acontece uma vez por mês com uma psiquiatra. [...] os profissionais [da equipe de enfermagem] que desejam participar, têm a chance de poder dividir suas histórias, suas angústias... [...] Mas isso tudo é algo voluntário. Ela, a psiquiatra, se dispôs a fazer isso com o grupo, então, não é nada do hospital. Foi uma necessidade percebida por ela e pela equipe [de enfermagem] (Eduarda, enfermeira). 
Como [o grupo] acontece pela manhã e o plantão está sempre corrido, o profissional que está trabalhando, na manhã, não consegue participar tanto. Mas tem um grupo, já fixo, que é composto pelos profissionais que trabalham à noite. Eles [profissionais de enfermagem que atuam no turno da noite] estão saindo do plantão e esperam a chegada do psiquiatra e participam, mesmo estando cansados, com sono; às vezes, até cochilam, mas não vão embora! [...] Sempre que possível, o profissional que está mais tranquilo, se ele desejar, ele também vem participar (Eduarda, enfermeira).

Os profissionais também revelaram despreparo quanto à formação recebida para atuação em saúde, o que também representa mais um fator que dificulta a adaptação ao contexto de atuação.

O psicólogo Tadeu acredita que as dificuldades inerentes à prática em saúde surgem desde a formação dos profissionais, que não são preparados para lidar com situações difíceis e são formados e treinados para serem onipotentes.

A formação também é perversa! Não permite... Vai construindo a capa durante cinco, seis ou sete anos, vai tricotando a capinha do super-homem... [risos] vai que dá, mas não dá! (Tadeu, psicólogo).

O médico Júlio traz à tona um exemplo de formação inadequada de oncologistas para prestar assistência a pacientes terminais. Ele contou que alguns colegas, por não tolerarem a dor e a ansiedade do contato com a terminalidade, optam por agendar retornos para seus pacientes após um longo período, de forma que eles fiquem muito tempo sem voltar ao consultório, reduzindo a frequência de contato com os mesmos. Porém, comentou, especificamente, sobre a formação em Medicina no HCFMRP-USP, pontuando que, nessa instituição, os futuros oncologistas são orientados e treinados para serem profissionais próximos, para que participem ativamente do cuidado a seus pacientes.

[...] me magoa muito, mas me irrita muito mais do que magoa. São profissionais da área oncológica que são tão despreparados [...] São aqueles que o paciente está em estadio final e eles somem! Então, eles cuidam do cara... imagino até de que jeito [...] O cara está em estadio final e o médico marca retorno de seis em seis meses... seis meses, [o paciente] já morreu e ele sabe disso! Então, esse cara, ele não é preparado... ele é médico! Ele não se envolve porque ele não quer... não vou nem dizer que ele não quer trabalho, ele não quer ansiedade, ele não sabe lidar com isso! Então, esse cara devia fazer tudo... não vou falar nem Oncologia, mas nem Medicina ele devia fazer! Eu já vi isso várias vezes e eu sou o contrário (Júlio, médico).

Lá [Oncologia Pediátrica], percebo a formação que é dada [...] o cara [profissional] participa mesmo! [...] o pessoal abraça, vai até o fim junto e, sai assim da sua vida... e isso é bom! [...] Acho que isso tem a ver com a 
formação de cada um e com a faculdade... a formação pessoal e a faculdade! (Júlio, médico).

O psicólogo Tadeu ressaltou a necessidade de pesquisas e reflexões por parte das instituições de ensino que formam profissionais para atuar na área de saúde, para que as práticas de cuidado sejam repensadas tanto em relação a pacientes e a familiares, como também, em relação aos próprios profissionais de saúde. Além disso, pontuou as possíveis contribuições deste estudo.

[...] os estudos, os pesquisadores, alguém precisa pensar nisso: como fazer isso [cuidar dos próprios profissionais de saúde] no hospital? O hospital precisa encarar que isso é uma forma de cuidado também! (Tadeu, psicólogo).

[...] as instituições de formação, as faculdades e universidades [...] nenhuma tem essa visão! Esse trabalho também vem a contribuir com isso, né... como formar o profissional para que ele saiba que será um profissional e que tem demandas? (Tadeu, psicólogo). 


\section{SÍNTESE COMPREENSIVA}

Neste capítulo, busquei construir uma síntese compreensiva a respeito das vivências de profissionais de saúde atuantes em Oncologia Pediátrica. Para isso, parti das categorias temáticas apresentadas no capítulo anterior “Apresentação e compreensão dos discursos”.

O início da atuação em Oncologia Pediátrica foi experimentado de maneira muito singular por cada um dos participantes. Enquanto para alguns, a chegada a esse contexto de trabalho ocorreu sem grandes sonhos ou planejamentos, como foi o caso do médico Júlio e da assistente social Regina, para outros, o desejo de atuar em Oncologia Pediátrica já existia mesmo antes de se tornarem profissionais. Logo, esse sonho foi semeado ao longo da própria formação e pôde ser colhido, alguns anos depois, como contaram o psicólogo Tadeu e a terapeuta ocupacional Ana.

Independentemente de terem sonhado ou não em trabalhar neste contexto, a escolha para aceitar atuar em Oncologia Pediátrica foi vivenciada, por muitos participantes, como um desafio, principalmente, pelo medo do desconhecido associado à falta de experiência de trabalho neste ambiente, e pelo questionamento sobre a própria capacidade profissional.

Apesar das dificuldades enfrentadas no início da atuação profissional, todos os participantes demonstraram abertura para entrar em contato com aquela nova realidade, buscando experimentar essa escolha, seja para mantê-la ou para renunciá-la em busca de atividades que fizessem mais sentido. Essa abertura inicial permitiu que eles fossem adquirindo conhecimento, transformando o até então desconhecido em sabido, desmistificando fantasias, desenvolvendo mecanismos que lhes permitiram adaptação às exigências daquele ambiente. A passagem do desconhecido para o conhecido também apareceu como facilitadora para a própria atuação, pelo fato de diminuir a ansiedade.

Todos os entrevistados, mesmo enfrentando as dificuldades, demonstraram satisfação por terem mantido a escolha inicial, bem como pela realização pessoal e profissional pelo trabalho desempenhado.

A atuação em Oncologia Pediátrica é vivenciada pelos participantes de forma paradoxal, já que a maioria deles revela experimentar momentos de desgaste emocional e dificuldades, que não se restringiram somente ao momento inicial de inserção a um novo contexto de trabalho, mas se mantiveram ao longo do tempo, alternados com sentimentos de satisfação e realização profissional. 
Sentimentos de impotência, angústia, frustração e desânimo foram relatados pelos profissionais como marcantes em momentos em que eles se deparam com dificuldades em seu trabalho. Esses sentimentos aparecem associados às seguintes situações: contato com pacientes em intenso sofrimento físico; fechamento de prognóstico de um paciente; circunstâncias de terminalidade e despedida; aproximação com o possível óbito de pacientes; contato com condições culturais e socioeconômicas de pacientes e familiares que representam obstáculos para compreensão de situações de adoecimento e tratamento e, para que eles coloquem em prática orientações feitas pelos profissionais de saúde.

Em todas essas situações relatadas, fica evidente que as dificuldades experimentadas pelos profissionais despertam sentimentos de impotência, por exigirem dos mesmos o contato com seus próprios limites enquanto seres humanos: independentemente da dedicação ou do investimento dos mesmos, a morte é inerente à condição humana; o sofrimento físico nem sempre consegue ser aliviado por condutas medicamentosas ou terapêuticas e os pacientes e familiares podem apresentar condições socioeconômicas e culturais difíceis de serem transpostas, o que evidencia que a própria atuação profissional possui um "raio de ação" importante, mas que delimita a perspectiva e as possibilidades de cuidado.

Além dos sentimentos de impotência e frustração gerados pelo desejo de controlar o incontrolável, os participantes demonstram também uma dificuldade para aceitar que o paciente é livre para assumir o próprio cuidado ao seu modo, independentemente do que os profissionais julgam ser o mais adequado. Essa característica evidencia o raciocínio paternalista que, em alguns momentos, parece permear as ações dos profissionais, escancarando a dificuldade que sentem de cuidar do outro sem ter a garantia de que o que “prescrevem” será seguido...

Especificamente em relação à morte, todos os profissionais entrevistados demonstraram consciência da facticidade da existência: o homem, por ser lançado no mundo, está exposto a condições não escolhidas por ele, como por exemplo, a situação do adoecimento que adentra a vida do paciente sem que ele tenha lhe dado permissão. Pude observar que, diante da possibilidade de perda de um paciente, os profissionais parecem ser tomados pela impotência, entrando em contato apenas com as restrições da existência. Dessa maneira, parecem sentir-se de mãos atadas, sem acreditar que há algo efetivo que possa ser oferecido para auxiliar os pacientes a encontrarem as possibilidades existentes em meio às restrições escancaradas. Mesmo tendo conhecimento sobre as possibilidades de atuação em situações de cuidados paliativos, terminalidade e morte, e conseguindo, muitas vezes, colocar essas formas de cuidado em prática, os entrevistados parecem significar essas práticas como 
dotadas de menor relevância, demonstrando que o foco de seus cuidados está voltado para a cura de seus pacientes, sendo a morte experimentada por eles com sofrimento e como um fracasso. Em situações de óbito de pacientes, os profissionais, além de serem invadidos por sentimentos de frustração e impotência, demonstraram dificuldades em aceitar os próprios limites que a vida ou a morte lhes apresentam.

Os profissionais contaram, porém, que passado o choque inicial da perda de um paciente, eles conseguem se restabelecer, resgatando o significado de seu papel profissional e mobilizando cuidados aos pais que perderam seu filho e aos demais pacientes e familiares que precisam continuar sendo assistidos. Parece que as exigências do trabalho chamam... e os profissionais parecem exigir de si mesmos que tenham condições para a elas responder em tempo hábil. Porém, pensando na própria saúde mental desses profissionais, é necessário que eles se permitam entrar em contato com a dor da perda. Caso contrário, se esse lado humano não puder aflorar, os profissionais terão que desenvolver, cada vez mais e de forma mais intensa e rígida, uma barreira que lhes sirva de proteção, mas que também impede um cuidado pautado por proximidade e envolvimento, tornando-os alheios à sua própria subjetividade.

Vale destacar, também, que o fato de os profissionais estarem expostos aos riscos da existência, além de mobilizar sentimentos de impotência e sofrimento, gera angústia já que, ao se depararem com os riscos enfrentados pelos seus semelhantes, eles se aproximam da própria condição de ser-para-a-morte. A assistente social Natália revelou que o ambiente hospitalar a coloca em contato frequente com a morte e, se antes ela não destinava tanta atenção à sua própria condição de ser finita, hoje ela se depara o tempo todo com a possibilidade de não-ser a qualquer momento.

Alguns participantes acreditam que as dificuldades que os profissionais de saúde enfrentam em sua prática profissional surgem desde a formação profissional, que os treinam para serem onipotentes e não oferece subsídios que os preparem para lidar com situações difíceis. Um dos participantes ressaltou a importância deste estudo bem como de outros que vêm sendo desenvolvidos por estimularem reflexões sobre a prática em saúde na atualidade.

Diante das dificuldades encontradas por cada um dos participantes, alguns deles questionaram a própria escolha profissional bem como a decisão de atuar em Oncologia Pediátrica, sendo que alguns pensaram, em diferentes momentos dessa trajetória, em renunciar a essa escolha.

Frente ao contato com tantas situações que mobilizam angústia e impotência, a satisfação que os profissionais entrevistados encontram em sua atuação e que os fazem manter a escolha de permanecer em Oncologia Pediátrica, a despeito de todos os questionamentos, 
parece estar associada, justamente, às vivências em que eles se sentem potentes, capazes de realizar seu trabalho de forma ativa, servindo ao próximo em momentos de sofrimento.

O médico Júlio, por exemplo, demonstrou satisfação ao perceber que conseguiu se vincular a um paciente que, inicialmente, apresentava atitude de distanciamento e mau-humor para com ele. Nesse caso, a impotência inicial pôde ser superada pelo fato de o profissional fazer uso de seus recursos de bom-humor e ironia para tocar o jovem e propor a ele uma nova maneira de relacionar.

A satisfação também está relacionada às situações em que os profissionais de saúde são capazes de orientar os pacientes e familiares a ponto de eles conseguirem compreender o adoecimento para aderirem ao tratamento de forma participativa e responsável. Vale lembrar que a dificuldade de compreensão de pacientes e familiares representa um desafio para alguns profissionais.

O reconhecimento também aparece de forma marcante nos discursos e parece que esses "feedbacks" recebidos oferecem tranquilidade e segurança para os profissionais, como se escancarassem que seus esforços foram válidos para alguém e que seus deveres profissionais foram cumpridos.

Além disso, o término do tratamento e a possibilidade da cura de grande parte dos pacientes permitem que os profissionais vivenciem seu trabalho como bem sucedido, como responsável por oferecer possibilidades de vida, diferentemente dos sentimentos de angústia, impotência e fracasso experimentados frente a situações de cuidados paliativos, terminalidade e óbito.

Os profissionais entrevistados demonstraram capacidade de exercer um cuidado que vai além das próprias atribuições e do próprio local de trabalho e essa forma de cuidar, que transcende os limites da própria atuação, parece ser mais uma alternativa criada pelos profissionais para se sentirem úteis e, consequentemente, menos impotentes e mais satisfeitos com seu trabalho.

Essa maneira de conduzir o trabalho, permeada por flexibilidade e criatividade, é possível devido à própria abertura dos profissionais para serem tocados pelas vivências de seus pacientes, criando formas de cuidar deles. Essa postura fica evidente, por exemplo, quando a assistente de enfermagem Clara e a assistente social Regina, ambas responsáveis por atendimento ambulatorial, deslocam-se para enfermaria ao serem requisitadas por pacientes ou familiares. A assistente de enfermagem Clara também revelou já ter ido à casa de pacientes, quando eles demonstraram desejo de tê-la por perto. O psicólogo Tadeu também apresenta esse movimento de ir ao encontro das necessidades do outro, ao se mostrar 
disponível para assisti-lo, além do atendimento psicológico, acompanhando o paciente enquanto ele vê um desenho animado na televisão, enquanto caminha no jardim ou ajudandoo a carregar suas malas quando é transferido de um quarto para outro na enfermaria. Porém, um dos participantes entrevistados revelou dificuldade para se relacionar com outro profissional, de sua mesma especialidade, de forma a oferecer uma assistência contínua e integrada na enfermaria e no ambulatório. No caso desse profissional, diferentemente dos demais que apresentam uma postura mais ativa, sendo capazes de construir, moldar, reformular suas atuações conforme as necessidades, ele parece assumir uma postura mais passiva. Assim, ficou evidente que a forma de desempenhar o trabalho varia de indivíduo para indivíduo dependendo dos recursos pessoais e profissionais de cada um.

As vivências em Oncologia Pediátrica também são experimentadas com satisfação por oferecerem oportunidades de aprendizado pessoal, pois funcionam como lições que permitem aos profissionais de saúde ressignificar a própria vida, redimensionando os problemas enfrentados no cotidiano. Os profissionais parecem admirar a capacidade de superação das crianças e dos adolescentes com câncer. Dessa forma, a despeito dos desafios vivenciados na prática de saúde, os entrevistados compreendem a relação de cuidado estabelecida com seus pacientes como sendo de "mão dupla", de forma que ambos se beneficiam e são transformados pelo encontro.

O fato de trabalharem em um hospital nacionalmente reconhecido por sua qualidade também parece despertar satisfação em alguns participantes. Porém, alguns deles revelaram sentimentos de desamparo em relação à instituição em que atuam. Diante do ambiente potencialmente estressor em que trabalham, mergulhados em situações capazes de mobilizar intenso sofrimento, todos os que abordaram esse assunto, comentaram que sentem falta de receber atenção e cuidado por parte da própria instituição. Eles reclamaram que não observam qualquer manifestação ou ação da mesma no sentido de promover práticas de cuidado a seus funcionários. Os profissionais de saúde ressaltaram a necessidade de medidas de apoio aos profissionais de saúde como forma de cuidado à saúde mental dos mesmos. Acreditam que, para que isso possa ser colocado em prática, é essencial que haja estrutura adequada, organização de uma rotina de atendimentos e contratação de equipes paralelas para cuidar dos funcionários.

Frente à ausência de movimento por parte da instituição hospitalar, os próprios profissionais têm buscado criar fontes de suporte para si, através da criação de grupos de apoio ou mesmo através de estabelecimento de relacionamentos mais íntimos com os colegas 
de trabalho, por meio de encontros e conversas informais dentro do próprio ambiente hospitalar.

A percepção de que o serviço de Oncologia Pediátrica possui diferenciais quanto à atuação em equipe, que revelam avanços em relação aos demais setores do HC, também parece ser outro aspecto que gera satisfação aos participantes. Alguns deles ressaltaram os seguintes aspectos como facilitadores para uma atuação integrada: o envolvimento entre os profissionais, a abertura para refletir, questionar e repensar condutas e a busca pelo aprimoramento constante. Além disso, ressaltam a disponibilidade para se atentarem às necessidades de pacientes e familiares, além da capacidade de se vincular aos mesmos.

Apesar de reconhecerem diferenciais, alguns participantes enfatizaram o quanto esse serviço ainda precisa se desenvolver para conseguir, de fato, realizar um trabalho interdisciplinar. Entre os obstáculos existentes, eles pontuam que a troca entre os profissionais ainda se restringe a aspectos do trabalho com pacientes e familiares, sendo que questões ligadas às próprias dificuldades e aos sentimentos despertados pela atuação neste contexto ainda aparecem raramente e apenas de forma velada, demonstrando que os profissionais não se sentem à vontade para compartilhar aspectos pessoais. Pontuaram, ainda, a dificuldade de comunicação devido à quantidade de profissionais de diferentes especialidades envolvidos e o fato de eles, nem sempre, compartilharem das mesmas ideias; a supervalorização dos médicos em detrimento dos demais profissionais; o poder e a autoridade desempenhados pela equipe médica; questões estruturais do hospital em que as salas dos profissionais encontram-se dispersas em diferentes locais e andares, representando obstáculos a esse contato frequente e espontâneo; ausência de um momento criado, justamente, para o encontro entre os profissionais e liderado por supervisores externos.

Foi possível notar que os profissionais não questionaram a importância da atuação interdisciplinar como um caminho adequado para prestar uma assistência de qualidade. Porém, houveram divergências quanto à compreensão dos mesmos em relação à forma de perceberem o trabalho do próprio grupo em que estão inseridos. Essas divergências parecem estar associadas à forma com que cada um significa o trabalho interdisciplinar, bem como suas percepções singulares a respeito do que seja a integração e a desintegração de uma equipe.

Vale ressaltar ainda que, apesar de os profissionais entrevistados terem relatado satisfação pelo trabalho desempenhado, a despeito das dificuldades enfrentadas, alguns deles dividiram sua percepção de que muitos dos seus colegas de trabalho não estão satisfeitos e não se sentem bem atuando em Oncologia Pediátrica. Uma participante revelou, inclusive, 
que alguns colegas apresentam sintomas de sofrimento psíquico e, principalmente os novatos costumam recorrer à medicação como forma de auxiliar o enfrentamento de um cotidiano de trabalho doloroso e, aparentemente, sem sentido para eles, o que alerta sobre a necessidade de se desenvolver medidas de cuidado a esses profissionais.

É preciso destacar que a forma com que cada profissional percebe o adoecimento infantil repercute na maneira como ele enxerga seu papel profissional e desempenha seu trabalho. Os participantes que veem os jovens pacientes com câncer como crianças mais sofridas devido à enfermidade e ao tratamento prolongado que enfrentam, baseiam suas condutas a partir do significado de que esses pacientes precisam de mais atenção e carinho e, por isso, necessitarão de um cuidado diferenciado. Já aqueles participantes que consideram que as restrições à existência e as repercussões psicológicas e sociais ocasionadas pelo câncer são muito semelhantes àquelas geradas por outras enfermidades crônicas, acreditam que as condutas adotadas devem ser também semelhantes às medidas que utilizam para atuar junto a jovens com outras doenças crônicas. A assistente social Natália, enfatizou, por exemplo, que apesar das singularidades, alguns aspectos da situação de adoecimento por qualquer enfermidade crônica - as queixas, angústias e preocupações - são vivenciados de forma muito semelhante por pacientes e familiares, o que faz com que o foco do cuidado prestado por ela, em diferentes setores da Pediatria, não seja tão diferente, sendo os atendimentos voltados, principalmente, para o acolhimento da família, o suporte na descoberta do diagnóstico e o auxílio para reorganização familiar diante do diagnóstico de uma doença crônica.

É possível pensarmos que, devido aos estigmas associados ao câncer, essa doença alcance uma visibilidade social e cultural que pode ser responsável por despertar em alguns profissionais o desejo de ampliar o cuidado que dedicam aos pacientes com câncer.

De uma forma geral, os profissionais entrevistados atribuem diferentes significados ao cuidar de crianças e adolescentes com câncer. Cuidar envolve acolhimento após o impacto do diagnóstico, escuta como forma de conhecer a história de cada paciente e suas necessidades, esclarecimento de dúvidas e oferta de informações como meio de diminuir fantasias e ansiedade causadas pela falta de conhecimento, acompanhamento para que os pacientes não se sintam sozinhos ao longo do tratamento, envolvimento, empatia, respeito aos limites colocados tanto pelos pacientes como pelos seus familiares, disponibilidade, criatividade e flexibilidade para atender às suas necessidades singulares, bom conhecimento e entrosamento com os colegas de trabalho.

Alguns participantes ressaltaram, também, a importância de oferecer um cuidado global, que vá além dos aspectos físicos e que transcenda o momento presente, atentando-se 
para as possíveis e futuras repercussões psicológicas e sociais do adoecimento e tratamento, visando a possibilitar o desenvolvimento saudável desses jovens. Comentaram, também, sobre o cuidado a pacientes terminais e familiares enlutados: para eles, o foco desse cuidado deve ser oferecer conforto e qualidade de vida, minimizar sofrimentos, facilitar a expressão de sentimentos e acolher ansiedades.

Independentemente dos significados atribuídos, os profissionais parecem associar sua função a uma responsabilidade assumida ao escolherem trabalhar em Oncologia Pediátrica: cuidar do outro! Mas, percebo que esse cuidar não envolve, simplesmente, cumprir um papel, mas vem acompanhado de abertura e desejo para estar-com esses pacientes.

É preciso destacar, porém, que a rotina exaustiva de trabalho e as próprias questões pessoais dos profissionais impedem uma entrega total a pacientes e familiares, e, ao compararem a própria atuação, o próprio investimento e envolvimento com os significados pessoais que atribuem ao que seria uma forma ideal de desempenhar seu papel, os profissionais são tomados por sentimentos de culpa, acreditando estar em dívida com o outro. Em contato com situações em que a vida parece tão vulnerável, a ponto de se extinguir a qualquer momento, os próprios profissionais parecem exigir, de si mesmos, uma oferta máxima enquanto há vida, pois a morte pode estar para bater à porta a qualquer momento. Tomados pela angústia da possibilidade do fim e desejando dar o melhor de si, em alguns momentos, os profissionais parecem significar que, por estarem diante de alguém em profundo sofrimento, a necessidade de qualquer outra pessoa se torna menos importante, dotada de menor valor, ilegítima, desrespeitosa com a necessidade do outro. Nessas ocasiões, por não se permitirem olhar para as próprias questões e tomados pela dor do outro, eles parecem esquecer que, para oferecerem o melhor de si, precisam estar bem tanto do ponto de vista físico como psíquico. Pude perceber que, ao exigirem o máximo de si, sem levar em conta as próprias necessidades, os participantes demonstraram dificuldades para se reconhecerem como seres humanos, dotados de limites, percebendo a si mesmos como fonte inesgotável de abertura e cuidado ao outro, de forma a afastar de si sentimentos de impotência.

Além disso, a própria capacidade que os profissionais possuem de se vincular a pacientes e familiares, considerada por muitos deles como essencial para a prestação de uma assistência de qualidade por possibilitar a empatia, por permitir que pacientes e familiares se sintam compreendidos e por facilitar a adesão ao tratamento, gera sentimentos de satisfação profissional mas, também, é responsável, segundo os próprios entrevistados, por muitos sofrimentos por eles experimentados. 
Apesar de acreditarem na importância de estabelecerem limites para o envolvimento com pacientes e familiares, de buscar separar aspectos pessoais e profissionais e reconhecerem as próprias limitações, os profissionais revelam que, nem sempre, conseguem colocar isso em prática. Eles alegam que a circunstância de adoecimento e sofrimento que ocasiona a construção dessa relação bem como o fato de o tratamento ser, em geral, longo, torna o envolvimento natural. Eles parecem não conseguir conceber a si mesmos desvinculados de suas funções profissionais; trata-se de uma realidade à qual eles estão fundamentalmente relacionados.

Para lidarem com todas as dificuldades com que se deparam no seu contexto de atuação, os entrevistados revelaram que, além dessas tentativas de limitar o envolvimento com pacientes e familiares, de separar aspectos pessoais e profissionais e de reconhecer as próprias limitações como formas de preservar a própria vida pessoal e evitar sofrimento excessivo, fazem uso de outros recursos de enfrentamento, entre eles: a espiritualidade que os auxilia a compreender, a ressignificar e a aceitar as situações difíceis vivenciadas e os mistérios do existir; a atenção aos próprios aspectos emocionais como forma de olhar para as próprias necessidades e cuidar de si; a experiência profissional que fornece subsídios para uma atuação com maior segurança, tranquilidade e proximidade; o apoio junto aos colegas de trabalho; a psicoterapia pessoal; as atividades físicas e as atividades manuais como formas de lazer para auxiliarem no alívio das tensões e para reabastecer a energia nos períodos em que não estão no hospital; o bom humor e a racionalização.

Pude observar que os profissionais de saúde, participantes deste estudo, relataram suas vivências em Oncologia Pediátrica através de diversos caminhos, sendo que nessas trilhas, suas vivências pessoais se mesclam com as experiências profissionais.

De uma maneira geral, as experiências, neste contexto, foram contadas de forma a abarcar a trajetória que eles percorreram ao longo do tempo, desde o momento em que esses profissionais iniciaram o trabalho neste setor da Pediatria. Tais relatos foram permeados ora por sentimentos de satisfação e de bem-estar, ora por dificuldades, questionamentos e angústia.

Segundo minha compreensão, para esses participantes, a atuação em Oncologia Pediátrica é uma possibilidade de aprendizado, seja pela dor e sofrimento, seja pela vitória e comemoração. É uma oportunidade de desenvolver a capacidade de olhar para o outro e para si mesmo, respeitando singularidades, tolerando diferenças. É um empurrãozinho para se permitir crescer com o outro, trocar com o outro, aprender com outro, contribuir para o desenvolvimento do outro; vibrar pelo outro, sendo esse “outro” um paciente, um familiar, um 
colega de trabalho... É um desafio e, ao mesmo tempo, um presente que aproxima esses profissionais da consciência da finitude, proporcionando-lhes movimentar em busca de um existir autêntico. 


\section{RefleXões SOBRe O EXISTIR dOS PROFISSIONAIS DE SAÚdE À LUZ DA PSICOLOGiA} FENOMENOLÓGICA

Este capítulo tem como objetivo realizar uma reflexão a respeito do existir dos profissionais de saúde em relação à atuação em Oncologia Pediátrica. Como foi mostrado no capítulo 5 - Trajetória Metodológica: um caminho para a compreensão do fenômeno, no item 5.2 - Enfoque Fenomenológico da Personalidade - para realização dessa reflexão, busquei como referencial teórico o Enfoque Fenomenológico da Personalidade proposto por Forghieri (2009), como forma de auxiliar na compreensão do fenômeno em estudo.

O leitor poderá perceber que, neste capítulo, em alguns momentos farei uso ora da primeira, ora da terceira pessoa do plural. Isso aparece, especificamente, ao abordar o enfoque fenomenológico da personalidade proposto por Forghieri (2009), devido à minha intenção de tentar manter, de forma mais próxima, o que foi proposto pela autora:

Outro ponto que merece esclarecimento refere-se ao estilo que adoto ao escrever este trabalho, pois [...] em alguns momentos, incluo o leitor no meu discurso, utilizando-me do "nós", para tentar chegar perto do leitor e levá-lo a participar da vivência de situações que são próprias não apenas de minha vida, mas da existência que ambos partilhamos como seres humanos semelhantes (Forghieri, 2009, p. 25).

\subsection{SER-NO-MUNDO}

Ao ser humano é essencialmente inerente ser-no-mundo (HEIDEGGER ${ }^{10}$, 1971, apud FORGHIERI, 2009, p. 27). Segundo Forghieri (2009), essa estrutura é originária e total, não podendo ser decomposta.

Esse mundo pode se apresentar a nós, ao mesmo tempo, como acolhedor ou hostil. Para Critelli (2007), a experiência humana, em sua fluidez constante e em sua mutabilidade, situada em um mundo inóspito, livre e sem segurança não é uma deficiência do existir dos homens, mas revela sua própria condição, quase como sua natureza.

\footnotetext{
${ }^{10}$ HEIDEGGER, M. Que é Isto a Filosofia? São Paulo: Duas Cidades, 1971.
} 
Mundo é entendido, pela Fenomenologia, como um conjunto de relações significativas dentro do qual a pessoa existe. Logo, nosso elo com o mundo pode ser tanto um lugar quanto uma pessoa (FORGHIERI, 2009).

Mas, é relevante ressaltar que:

[...] o mundo não é apenas um conjunto de objetos ou pessoas, existindo por si mesmos, pois cada um deles se torna um determinado objeto ou pessoa em virtude de ter um significado para quem o percebe (FORGHIERI, 2009, p. 28).

Assim, os significados atribuídos por cada indivíduo às experiências emergem a partir dessa relação homem-mundo. Dessa maneira, um mesmo fato - câncer infantil - é experienciado de forma única por cada pessoa que com esse fato se relaciona: cada um dos profissionais de saúde entrevistados, a partir da própria intencionalidade, atribui sentidos singulares às suas vivências em Oncologia Pediátrica.

A Fenomenologia considera ser e mundo como indissociáveis, porém o mundo apresenta-se ao homem sobre três formas diferentes e simultâneas - circundante, humano e próprio - e o homem existe neste mundo, também, a partir de três maneiras diferentes e simultâneas - preocupada, sintonizada e racional (FORGHIERI, 2009).

O "Mundo" Circundante consiste no relacionamento da pessoa com o ambiente, envolvendo o que está concretamente presente nas situações vividas pela pessoa (coisas, plantas, animais, leis da natureza e seus ciclos - dia e noite, estações do ano, calor, frio, intempéries) e pelo nosso corpo com suas necessidades e atividades (alimentação, vigília e sono, atuação e repouso, viver e morrer) em seu contato com o mundo. Envolve as condições externas e o próprio corpo humano (FORGHIERI, 2009).

O “mundo” circundante abrange os condicionamentos aos quais estamos sujeitos sendo, de certo modo, por eles determinados, por vivermos concretamente num ambiente, e pela limitação decorrente de nossa corporeidade. Por isso, a adaptação e o ajustamento são os modos mais apropriados do homem relacionar-se com este mundo: adaptar-se ao frio ou ao calor; ajustar-se às necessidades de sono e alimentação, pois nada é possível de ser feito para modificar o clima e as próprias necessidades biológicas (FORGHIERI, 2009).

Nas falas dos participantes, em vários momentos, fica evidente que esses profissionais de saúde estão o tempo todo em contato com situações que escancaram os limites do ser humano e que requerem dos mesmos mobilização de formas de adaptação. A rotina de trabalho os aproxima de pacientes que se descobrem com câncer e que, pegos de surpresa, veem suas vidas mudarem de trajetos, sendo que planos são adiados e novas prioridades 
tomam lugar dos antigos projetos. Nessas ocasiões, o trabalho dos profissionais envolve, além de oferecer tratamento para a doença, ajudar o paciente a desenvolver formas de adaptação à realidade não desejada.

Os profissionais relatam a impotência que experimentam ao se depararem com situações que envolvem sofrimento físico e morte, já que, mesmo fazendo uso de todas as terapêuticas existentes, nem sempre conseguem oferecer alívio à dor sentida pelos jovens enfermos ou devolver-lhes a vida que se encontra tão ameaçada. Logo, não só os pacientes, mas também os próprios profissionais de saúde precisam desenvolver formas de adaptação e ajustamento à realidade de sua atuação.

O caráter determinista do "mundo" circundante desperta sentimentos de angústia no homem, pelo fato de ele se ver impotente em diferentes situações (FORGHIERI, 2009).

O homem, com o intuito de aliviar sentimentos de angústia ocasionados pelo contato com a impotência e visando a alcançar tranquilidade e segurança, busca e, até certo ponto consegue, exercer alguma ação sobre sua natureza e sobre seu próprio corpo. Ele consegue, por exemplo, exercer algum controle sobre seus instintos, domesticar alguns animais, elaborar objetos que lhe sirvam de utensílios e nivelar planaltos. Porém, essa ação e esse controle sobre o “mundo” circundante são temporários e relativos, já que a natureza e o seu próprio corpo mantêm certo poder de se imporem ao homem, por exemplo, através de desastres naturais e da morte (FORGHIERI, 2009). Logo, por mais que o homem tente, não consegue se livrar de sua condição ontológica de ser finito.

Mas, vale ressaltar que não nos encontramos completamente determinados.

O ser humano, embora sofra limitações de seu ambiente e de sua corporeidade e necessite adaptar-se a eles, possui a capacidade de transcendê-los por meio da consciência que tem das situações que vivencia (BINSWANGER $^{11}$, 1967, p. 241 apud FORGHIERI, 2009, p. 30).

No caso do adoecimento, de fato, não é possível que o paciente escolha abrir mão da enfermidade, retornando à vida anterior à sua chegada, pois a doença ao ser determinada pelo “mundo” circundante, coloca-se como algo para ser vivido. Como pontua Rossi (2006), essa realidade constitui-se como algo que já encontrou morada no ser-no-mundo dessas pessoas. Apesar disso, o indivíduo poderá encontrar maneiras de se adaptar a ela e de buscar formas mais eficazes de com ela lidar. Assim, por exemplo, em casos de definição de cuidados paliativos e terminalidade, é possível auxiliar o paciente a resgatar o sentido de sua vida

\footnotetext{
${ }^{11}$ BINSWANGER, L. El caso de Ellen West; La escuela de pemsamiento de analisis existencial; El caso de Ilse. In: May, R. (org.). Existência. Madri: Gredos, 1967.
} 
através da retomada de sua história anterior ao adoecimento, acompanhá-lo em rituais de despedida, contribuir para que ele consiga desfrutar momentos de vida mesmo diante da proximidade de não-ser mais.

Com relação aos profissionais de saúde, ao se depararem com situações de adoecimento, cuidados paliativos, terminalidade e morte, eles não conseguem abrir mão dessa facticidade, mas podem encontrar formas de lançar-se às possibilidades existenciais, através de maneiras de estar e cuidar do outro enquanto ainda há vida.

Com relação ao "Mundo" Humano, este se constitui pelo encontro e convivência da pessoa com seus semelhantes (FORGHIERI, 2009). Segundo Heidegger ${ }^{12}$ (1971) apud Forghieri (2009, p. 28), “a essência do homem está em ser relativamente a algo ou alguém”.

Nos discursos dos profissionais participantes, estavam intrínsecos aspectos de suas relações estabelecidas com pacientes, familiares e colegas de trabalho. Conforme Forghieri (2009) coloca, o existir é originariamente ser-com-o-outro. Desde o nosso nascimento encontramo-nos em situações que incluem a presença de alguém, embora o compartilhar humano nem sempre seja vivenciado de fato.

De acordo com Heidegger ${ }^{13}$ (1988, p. 172 apud FORGHIERI, 2009, p. 31), “mesmo o estar só é ser-com, no mundo. Somente 'num' ser-com e 'para' um ser-com é que o outro pode faltar. O estar só é um modo deficiente de ser-com”.

O homem pode se relacionar de diferentes modos com os entes que se apresentam a ele, mas não pode não se relacionar, mesmo a indiferença é um modo de relação; entes não dotados do modo de ser da existência, como uma mesa ou uma pedra, não podem ser indiferentes a outro ente, pois não se relacionam com outros entes enquanto entes, não são abertura de sentido (MATTAR; SÁ, 2008, p. 198).

Dessa forma, mesmo nos momentos em que os participantes relatam, por exemplo, que não há disponibilidade entre os próprios profissionais para esse encontro, para trocas de experiências, para compartilhar vivências, podemos falar em ser-com.

Diferente do relacionamento com o "mundo" circundante, em que o homem costuma utilizar-se dos objetos ou adaptar-se ao ambiente sem deles receber uma resposta, no encontro com o outro, no “mundo” humano, ocorre uma relação de reciprocidade, marcada por uma influência mútua (FORGHIERI, 2009).

Segundo Mattar e Sá (2008, p. 198),

\footnotetext{
${ }^{12}$ HEIDEGGER, M. Que é Isto a Filosofia? São Paulo: Duas Cidades, 1971.

${ }^{13}$ HEIDEGGER, M. O Ser e o Tempo. 2.ed. Petrópolis: Vozes, 1988.
} 
O ser-aí humano sempre coexiste com o outro, nunca é um sujeito individual subsistindo apenas para si mesmo; por coexistirem sempre junto às mesmas coisas de um mesmo mundo, os homens contribuem, conjuntamente, cada um segundo seu modo de "ser-no-mundo-com-o-outro".

Nos discursos dos participantes, essa influência mútua aparece no contato que os profissionais de saúde estabelecem entre si, com os pacientes e com os familiares dos mesmos. O "mundo" humano permite aos indivíduos partilhar, entre si, experiências comuns e distintas, possibilitando a construção de suas identidades.

A respeito da convivência com pacientes com câncer, os participantes revelam que o vínculo com eles estabelecido lhes proporciona aprendizado pessoal e profissional, sendo esse convívio experimentado como oportunidade para grandes "lições de vida”. Os profissionais entrevistados parecem desfrutar dessas relações, como forma de redimensionar valores e de ressignificar suas próprias vidas bem como suas experiências profissionais.

Com relação a essa possibilidade de ressignificação, como foi mostrado anteriormente, o mundo - e quando falamos dele, podemos pensar nos objetos, nas pessoas, nas nossas lembranças, por exemplo - não possui um significado em si mesmo; ao contrário, ele adquire um sentido a partir do olhar de quem o percebe. Esses significados são construídos não por um sujeito isolado, mas a partir das relações que esse mesmo indivíduo estabelece no convívio com as demais pessoas que também atribuem significados às suas vivências no mundo.

O mundo recebe seu sentido, não apenas a partir das constituições de um sujeito solitário, mas do intercâmbio entre a pluralidade de constituições dos vários sujeitos existentes no mundo, realizado através do encontro que se estabelece entre eles (FORGHIERI, 2009, p. 19).

Vale destacar que a ressignificação de vivências é possível pelo fato de os seres humanos e os significados atribuídos por cada um deles às suas experiências não serem estáticos, podendo ser reformulados a partir da abertura do indivíduo para olhar uma mesma situação a partir de outro prisma.

No discurso da assistente social Regina, ela revela que o conhecimento a respeito da função de cada um dos procedimentos realizados para o tratamento de câncer foi essencial para a compreensão e, consequentemente, para a ressignificação dos mesmos. A assistente social Natália também pontua que a experiência de onze anos trabalhando em Oncologia Pediátrica, lidando de forma próxima e constante com a morte de pacientes, fez com que ela atribuísse à morte um novo sentido, aceitando-a como parte da existência. 
Além disso, é pelo fato de o homem ser um ser de relação, um ser-com, que ele consegue compreender seus semelhantes, apesar das singularidades de cada um no ato de perceber diferentes situações (FORGHIERI, 2009). É essa capacidade de compreensão que possibilita ao ser humano a empatia.

De acordo com Forghieri (2009, p. 19),

[...] em sua vivência cotidiana, os seres humanos, embora tenham suas próprias peculiaridades, existem todos no mundo, constituindo-o e constituindo-se, simultaneamente. Possuímos, de certo modo, uma "comunalidade", pois todos nós vivemos no mundo e existimos uns com os outros, com a capacidade de nos aproximarmos e de compreendermos mutuamente as nossas vivências.

Nos discursos dos participantes, essa capacidade de se colocar no lugar do outro para tentar ver o mundo segundo olhos dele, permite-lhes compreender o sofrimento dos pacientes e familiares, aproximando-se de suas necessidades singulares. Mas, ao mesmo tempo, é essa empatia que faz com que, muitos deles, se sintam tomados pela dor do outro, sem conseguir transcendê-la a ponto de mobilizar os próprios recursos necessários para cuidar da dor desse indivíduo que está diante de si. Nesses casos, os profissionais demonstraram dificuldades para estabelecer a necessária diferenciação eu-outro, a desidentificação com as experiências de seus pacientes, o que é essencial para que seus recursos pessoais e profissionais não sejam bloqueados a ponto de eles não conseguirem mobilizar alternativas eficazes para desempenharem a assistência necessária.

Logo, parece necessário que cada profissional de saúde encontre sua medida ideal, aquela que lhe permite estabelecer um relacionamento saudável com seus pacientes, sem culminar no esquecimento das próprias necessidades e de seus limites pessoais, que é o que fica evidente nas falas do psicólogo Tadeu.

[...] sinto a dor do outro, mas é do outro, a dor não é minha! [...] é do outro e eu posso estar com o outro, mas não no lugar do outro e isso também me protege... me protege no sentido de que me deixa tranquilo para poder agir (Tadeu, psicólogo).

Além de o ser-com oferecer aos indivíduos a possibilidade de compreensão mútua, permite também que cada indivíduo tome consciência de sua maneira de existir e oferece-lhes a oportunidade de desenvolvimento através do questionamento e do contato com as diferenças. 
Alguns participantes deste estudo enfatizaram a importância de haver momentos de encontro entre os profissionais da equipe de saúde, como uma forma de apoio e suporte entre eles. Porém, ao mesmo tempo em que o trabalho junto a profissionais de diferentes especialidades e com diferentes maneiras de pensar, promove enriquecimento pela troca e pela diversidade, provoca também dificuldades no relacionamento, já que nem todos os profissionais conseguem lidar com as diferenças e nem sempre estão preparados para tematizá-las visando a aprimorar a assistência prestada através dessas reflexões, debates e questionamentos.

Vale pontuar, ainda, que é a partir dos encontros, da convivência e das relações estabelecidas entre pacientes, familiares e profissionais de saúde, pelo fato de o homem ser um ser-com, que se torna possível a construção de relações de cuidado.

Segundo Ferreira (2010), Heidegger define “cuidado” diferenciando o cuidado desenvolvido pelo ser humano na relação estabelecida com as coisas simplesmente dadas “ocupação” (Besorgen) - do cuidado do indivíduo com os seus semelhantes - "preocupação” (Fürsorge).

Pelo fato de o fenômeno em estudo tratar-se das vivências de profissionais de saúde junto a crianças e adolescentes com câncer, vou me ater ao modo de cuidado do ser humano com seus semelhantes - a “preocupação”.

A preocupação pode se apresentar através de dois modos: a substituição e a anteposição. Enquanto a substituição envolve um fazer pelo outro, dizer o que ele deve fazer, retirando-o do próprio cuidado, a anteposição clama ao ser pela responsabilização de sua própria existência, devolvendo a ele o cuidado de si (FERREIRA, 2010).

Pude perceber, nos discursos dos participantes, que o cuidado por eles prestado a seus pacientes, bem como na relação com seus colegas de trabalho é permeado pela alternância entre momentos de substituição e de anteposição.

A substituição aparece relacionada, por exemplo, às situações em que os profissionais demonstram exercer uma atuação pautada por paternalismo, revelando a existência de dificuldades para reconhecer e aceitar que seus pacientes são livres para conduzir suas vidas segundo suas próprias perspectivas e interesses, muitas vezes, inclusive, abdicando das recomendações orientadas pelos profissionais responsáveis pelo seu cuidado. Além disso, a substituição fica evidente nos relatos em que os participantes revelam vivenciar situações marcadas por autoritarismo entre os próprios colegas de trabalho, que demonstram dificuldades para trabalhar em conjunto, adotando condutas sem levar em conta os demais 
integrantes da equipe, tomando decisões em nome de todos, impedindo uma participação ativa de cada um dos membros dessa equipe no cuidado prestado aos pacientes.

Já a anteposição se faz presente em momentos em que os profissionais conseguem se abrir à perspectiva do outro e construir novos saberes, tanto na relação com seus pacientes, como com seus colegas de trabalho. Nos discursos dos entrevistados, isso fica evidente em situações em que os profissionais demonstram abertura e disponibilidade para trocas com os colegas, realizando intercâmbios entre perspectivas, levando em consideração as percepções singulares dos envolvidos nessa relação de cuidado. Também aparece quando os profissionais conseguem se abrir às demandas de seus pacientes, atuando sem invadir os limites colocados por eles e respeitando suas escolhas e seus significados.

É possível perceber que, apesar da importância do “mundo” humano, do ser-com-ooutro para a compreensão entre os seres humanos, bem como para o desenvolvimento de cada um através da própria compreensão, em alguns momentos, as relações estabelecidas entre as pessoas assemelham-se aos relacionamentos do “mundo” circundante, quando a atualização de potencialidades peculiarmente humanas - como a liberdade e a responsabilidade - são barradas, dando lugar à adaptação e ao ajustamento (FORGHIERI, 2009).

Com relação ao “Mundo” Próprio:

[...] consiste na relação que o indivíduo estabelece consigo mesmo, ou, em outras palavras, no seu ser-si-mesmo, na consciência de si e no autoconhecimento [...] Caracteriza-se pela significação que as experiências têm para a pessoa e pelo conhecimento de si e do mundo (FORGHIERI, 2009, p. 32-33).

A comunicação do indivíduo consigo mesmo e com os outros é possível, tanto pelo pensamento e pela linguagem discursiva, através da emissão de juízos e do raciocínio metódico, por exemplo, como de forma intuitiva por meio do olhar, de gestos, atitudes, sentimentos experienciados e manifestados na vivência imediata pré-reflexiva.

Conforme a pessoa vai descobrindo quem é, tomando consciência de si, também vai se abrindo para conhecer o mundo que a cerca, sob nova perspectiva (FORGHIERI, 2009). Além disso, as próprias situações que ela vivencia, relacionando-se com o "mundo" circundante e com o "mundo" humano, também lhe oferecem condições necessárias para essa descoberta e para o reconhecimento de si.

Nos relatos dos participantes, esse autoconhecimento aparece como resultado de seus questionamentos, por exemplo, a respeito da escolha profissional bem como da busca pelos 
sentidos de se manter ou não em um emprego que os aproxima tanto do sofrimento e da morte.

É a consciência de si e o autoconhecimento que possibilitam a autotranscendência, que consiste na "capacidade do ser humano de ultrapassar o momento concretamente presente, o aqui e agora, o espaço e o tempo objetivos” (FORGHIERI, 2009, p. 31).

A autotranscendência:

permite ao ser humano tanto voltar-se para o passado como, ao mesmo tempo, lançar-se no futuro para refletir e avaliar seus próprios recursos e as possibilidades que possui para enfrentar, não apenas a situação imediata, mas, para ir, imaginativamente, muito além dela (FORGHIERI, 2009, p. 3233).

É justamente por essa capacidade de autotranscendência que, os participantes conseguem, por exemplo, lançar-se ao passado, rever suas histórias, as escolhas que fizeram, as dificuldades enfrentadas, ressignificar vivências, bem como se jogar no futuro buscando avaliar como desejarão estar, para então, investirem no presente, seja questionando as próprias escolhas, abandonando antigos projetos, resgatando outros, criando novas possibilidades mais adequadas à sua atual forma de existir.

Segundo Vendruscolo (2006, p. 100), “transcender a situação vivida não é apenas superá-la com o passar do tempo, é preciso lançar-se em um movimento constante de atribuições de sentido àquilo que se apresenta ao longo da existência”.

Pode-se dizer que o mundo próprio desses profissionais de saúde compreende toda a rede de significações que acompanha suas existências, rede essa que é tecida constantemente, num movimento contínuo, nunca estanque, composta inclusive pelas suas vivências profissionais junto a crianças e adolescentes com câncer.

Como foi mostrado, no início deste capítulo, o ser-no-mundo envolve os aspectos do mundo - circundante, humano e próprio - e as maneiras de o homem existir no mundo preocupada, sintonizada e racional.

Com relação às maneiras do homem se relacionar com o mundo, inicialmente, é preciso pontuar que a vivência cotidiana imediata é a forma primordial de o homem existir no mundo. Através dela, o indivíduo tem uma compreensão global, intuitiva e pré-reflexiva de seu existir. Trata-se de um experienciar imediato que envolve um experienciar de si, das situações, de suas lembranças, ações e expectativas que é anterior a uma elaboração racional (FORGHIERI, 2009). 
A maneira com que cada indivíduo compreende o mundo é permeada por sentimentos. De acordo com Forghieri (2009), o sentimento contido em cada compreensão se apresenta sempre sob a forma de agrado ou desagrado.

Compreendemos nosso existir através de um sentimento pré-reflexivo de intranquilidade, mal-estar e preocupação, alternando continuamente, com sentimentos de tranquilidade, bem-estar e sintonia em relação a mim e ao mundo que me cerca (FORGHIERI, 2009, p. 36).

\section{Já a Maneira Preocupada de existir:}

consiste em um sentimento global de preocupação, que varia desde uma vaga intranquilidade, por ter que cuidar de algo, até uma profunda sensação de angústia, que chega a nos dominar por completo. Refere-se não somente às situações concretamente presentes na vida, mas também àquelas que já aconteceram e que são relembradas, aquelas que não aconteceram, mas a pessoa teme que venham a se concretizar e as que surgem sem que ela perceba os motivos para seu aparecimento (Forghieri, 2009, p. 36).

Essa maneira de existir encontra-se presente no cotidiano, mais frequentemente, de forma branda e imprecisa, sendo potencializada em algumas situações, como quando vivenciamos grandes contrariedades, enfrentamos um perigo ou precisamos assumir decisões importantes (FORGHIERI, 2009).

Os participantes relataram ter enfrentado algumas dificuldades no decorrer de sua inserção no serviço de Oncologia Pediátrica. Segundo eles, essas dificuldades estavam ligadas, principalmente, à falta de experiência em atuar junto a essa clientela. Pode-se observar que o medo do desconhecido foi responsável por potencializar ansiedades naquele momento de chegada a um novo ambiente de trabalho. No período inicial, os participantes parecem ter experimentado sentimentos de intranquilidade e preocupação, questionando até mesmo a própria capacidade profissional para atuar neste contexto. Com o passar do tempo, a experiência adquirida, bem como a familiarização com o contexto de trabalho puderam proporcionar atuações pautadas por maior tranquilidade e segurança. Porém, mesmo tomando conhecimento do ambiente de trabalho, tanto em relação às pessoas que ali atuam, como às tarefas a serem desempenhadas, ainda sim é necessário que os profissionais tenham abertura para se soltar à imprevisibilidade, de forma a ter coragem para enfrentar os riscos inerentes ao existir, que escapam às nossas tentativas de controle e previsibilidade.

Vale destacar que a angústia é o modo mais profundo da existência preocupada. Tomados pela angústia, somos dominados por sentimentos de aflição e impotência para nos livrarmos dela já que, diferente do medo, que possui objetos identificados a serem vencidos, a 
angústia não possui um objeto definido em relação ao qual possamos nos envolver e agir, para superar. "Por esse motivo, procuramos, frequentemente, transformar a angústia em medo, cujos objetos identificamos e tentamos vencer” (FORGHIERI, 2009, p.37).

Segundo a autora mencionada, somente entrando em contato com a própria angústia é possível compreendê-la - o que é possível através da maneira racional de existir (abordada em seguida) - para, então, transformá-la em medos concretos. Quando se consegue transformar a angústia, difusa, sem objeto definido, em medo concreto, é que se torna possível mobilizar recursos para enfrentá-lo (FORGHIERI, 2009).

Dessa forma, a angústia inicial vivenciada pelos participantes ao se inserirem em um novo contexto de trabalho, aos poucos, pôde ser olhada e compreendida de forma a ser transformada em algo concreto - o medo do desconhecido. A partir de então, os profissionais puderam mobilizar recursos para superá-lo, por exemplo, através da busca de conhecimentos e interação com outros profissionais mais experientes.

Segundo Tillich (1972, p. 35), "tentamos transformar a angústia em medo e ir, corajosamente, de encontro aos objetos nos quais a ameaça se corporifica”.

Apesar disso, por mais que consigamos, corajosamente, vencer os objetos de nossos medos, vivenciando alguns momentos de tranquilidade, estaremos sempre sujeitos ao reaparecimento da angústia, sem poder vencê-la definitivamente, já que ela é inerente à condição humana, na qual está contida a certeza de que um dia morreremos. A morte é o fundamento de todas as ameaças que tentamos objetivar no decorrer de nossa existência (FORGHIERI, 2009).

Pelo fato de ser-com, os profissionais de saúde entrevistados entram em contato constante com a possibilidade de perda de pacientes e com a morte propriamente dita e, consequentemente, em contato com a angústia, o que os torna vulneráveis do ponto de vista emocional. Além disso, o contato com a morte do outro aproxima esses profissionais, o tempo todo, do fato de eles também serem seres mortais.

A angústia aparece de forma evidente no discurso da assistente social Natália, ao dizer que a morte permeia a existência humana vinte e quatro horas por dia! Ou seja, ela tem o caráter de imprevisibilidade... Ela pode chegar a qualquer momento, para qualquer um, independentemente da idade, das condições de saúde, dos recursos financeiros. Ao ouvi-la dizer essas palavras, foi como se ela escancarasse a fragilidade humana, o quanto o homem vive exposto, sem garantias quanto ao seu viver, bem como quanto ao dia em que deixará de ser. 
[...] nós somos frágeis mesmo... a morte faz parte do cotidiano da nossa vida vinte e quatro horas por dia! (Natália, assistente social).

O médico Júlio também enfatiza a falta de controle sobre a morte - o que também demonstra a necessidade humana de se adaptar aos determinismos do "mundo" circundante, pelo fato de a morte ser uma condição ontológica do homem.

[...] outro dia mesmo [...] morreu o Secretário da Saúde do Estado de São Paulo, de infarto. Quer dizer, tem coisa mais absurda do que isso? [...] o Secretário de Saúde morreu chegando no Incor [Instituto do Coração]! O Tom Jobim morreu de infarto em Manhattan! Quer dizer, morre! Infelizmente, morre! Morre de idade, de acidente, de doença! (Júlio, médico).

Já a Maneira Sintonizada de existir acontece ao "vivenciar momentos de sintonia e tranquilidade, quando nos encontramos envolvidos de forma agradável com algo ou alguém” (FORGHIERI, 2009, p.37).

É um momento de harmonia em que sentimos que há uma fusão numa totalidade, uma fusão entre tempo e espaço, finito e infinito, momento concreto e eternidade, particularidades do homem e do mundo (BUBER, $1974^{14}$ apud FORGHIERI, 2009, p. 38).

A manifestação mais profunda da maneira sintonizada de existir consiste numa vivência de completa harmonia de nosso existir no mundo, porém, essa vivência de completa sintonia dura apenas alguns instantes. Além de acontecer algumas vezes e apenas por alguns instantes, tende a ocorrer de forma menos intensa, consistindo apenas num tênue e agradável sentimento de bem-estar e tranquilidade (FORGHIERI, 2009).

Percebo que os profissionais participantes deste estudo, ao relatarem os motivos que os levam a continuar atuando em Oncologia Pediátrica a despeito das dificuldades que encontram em seu trabalho, pontuam vivências em que experimentam a maneira sintonizada de existir. Nesses momentos, os profissionais percebem o quanto encontram sentido em sua atuação profissional, significado esse que aparece ligado ao vínculo estabelecido com os pacientes, à possibilidade de servir ao próximo em um momento difícil de sua trajetória existencial e ao fato de a convivência com esses pacientes funcionar como aprendizado e lição de vida.

A maneira sintonizada de existir também se desvelou no próprio momento da entrevista, em que profissionais demonstraram e relataram o bem-estar sentido por poderem contribuir com este trabalho bem como por relembrarem suas vivências neste contexto.

\footnotetext{
${ }^{14}$ BUBER, M. Pointing the way. Nova York: Schoken Books, 1974.
} 
Com relação à Maneira Racional de existir, ela acontece quando, após vivenciar completa preocupação ou sintonia, o indivíduo passa a refletir a respeito desses momentos e analisá-los para verificar o que são, como chegou a eles e o que fazer para mantê-los ou não, vivê-los novamente ou não. É essa maneira de existir que permite uma elaboração intelectual das experiências cotidianas imediatas (FORGHIERI, 2009).

Como seres racionais, temos necessidade de refletir sobre nossa vivência cotidiana imediata, analisando-a, para que a partir dessa análise possamos encontrar elementos objetivos e chegar a algumas conclusões que nos permitam conhecer o nosso existir no mundo e elaborar uma "teoria” sobre o mesmo. Essa “teoria” sobre nossa vida oferece-nos certa segurança, tanto para explicar situações que já vivemos ou estamos vivendo, como para planejar futuras ações (FORGHIERI, 2009).

Pude perceber, no encontro com os participantes, que o momento da entrevista foi uma oportunidade não só de eles dividirem suas experiências, mas também, de refletirem sobre elas, organizá-las, lançar luz a algumas questões que, muitas vezes, passam despercebidas no cotidiano.

Durante a entrevista, ao recordarem vivências junto aos pacientes por eles atendidos, alguns profissionais se emocionaram... Lágrimas foram derramadas, olhos ficaram marejados... Esses momentos apareceram associados tanto à maneira preocupada de existir quanto à maneira sintonizada de existir: os profissionais, ao se aproximarem de forma reflexiva de vivências de sofrimento e de alegria, perda e cura trouxeram à tona seus sentimentos em relação ao cuidado a crianças e adolescentes com câncer.

O fato de os profissionais, no dia a dia, não pararem para refletir sobre suas vivências, não é algo específico deles, mas de todos os seres humanos. Nessas situações, não quer dizer que a racionalidade está adormecida mas, sim, que quando as experiências agradáveis ou desagradáveis são pouco intensas, o foco acaba por se restringir aos afazeres cotidianos. Já em momentos de muita angústia, o ser humano é forçado a refletir sobre sua aflição, tentando encontrar os motivos que o levaram a esse sofrimento e buscar os meios para tentar superá-la ou aliviá-la (FORGHIERI, 2009).

A maneira racional de existir também aparece nas vivências dos participantes em reuniões multiprofissionais, quando eles conseguem utilizar o momento de encontro para refletirem sobre os aspectos do adoecimento de seus pacientes e para analisarem e repensarem as condutas adotadas no cuidado, bem como para olharem para suas dificuldades e sentimentos mobilizados nos contatos estabelecidos no ambiente de trabalho. 
Como foi dito anteriormente, ao abordar a maneira preocupada de existir, é a maneira racional que permite transformar angústia em medo. O medo tem um objeto definido e a visualização deste objeto torna possível nosso envolvimento e participação na sua percepção, de forma a verificar e mobilizar os recursos para enfrentá-lo (FORGHIERI, 2009).

A maneira racional de existir possibilita, também, avaliarmos se estamos percebendo a realidade de forma adequada.

Embora cada um tenha um modo peculiar de compreender as situações, somos todos seres humanos vivendo num mesmo mundo, havendo aspectos comuns em nossa existência, que nos permitem convivermos e partilharmos das mesmas experiências. [...] Agimos de acordo com nosso modo de compreender as situações, porém, nossas ações só serão eficientes se forem adequadas à realidade dos acontecimentos (FORGHIERI, 2009, p. 39).

É importante mencionar que as três maneiras de existir - preocupada, sintonizada e racional - ocorrem de forma articulada e relacionada na vivência humana, havendo apenas predominância maior ou menor, ora de uma, ora de outra. Os sentimentos agradáveis e desagradáveis, associados, respectivamente, à maneira sintonizada e preocupada de existir, podem surgir próximos e entrelaçados na vivência imediata e a maneira racional, apesar de estar voltada para uma análise objetiva das situações, não deixa de ser permeada por algum nível de preocupação e/ou de sintonia (FORGHIERI, 2009).

\subsection{TEMPORALIZAR}

O temporalizar refere-se a uma maneira singular de registrar o tempo, não desempenhando relação com o tempo cronológico. Dependendo de como o indivíduo está, preocupado ou sintonizado, ele vivencia o tempo de uma forma única (FORGHIERI, 2009).

O existir é experienciado com uma "velocidade" e intensidade que se alteram dependendo do sentido atribuído pela pessoa a cada experiência, da forma com que determinadas situações são vivenciadas, sejam elas acompanhadas de sentimento de agrado ou desagrado. Em geral, os momentos vivenciados com sintonia e contentamento transcorrem rapidamente, enquanto aqueles experimentados com desagrado, preocupação, contrariedade e tédio cursam lentamente (FORGHIERI, 2009). 
Além de a existência ser vivenciada com certa "velocidade”, ela é experimentada também com uma "extensibilidade”:

[...] nosso temporalizar estende-se, tanto em relação ao nosso passado como em direção ao futuro, com amplitude ou restrição. Assim sendo, posso vivenciar o meu existir tendo como fundo um passado com poucas ou muitas experiências significativas e um futuro com poucas ou muitas possibilidades de prosseguir a minha existência. A vivência de sintonia e contentamento expande o temporalizar, enquanto a preocupação e a contrariedade o restringem (FORGHIERI, 2009, p. 43).

Conforme Forghieri (2009, p. 42) pontua, na vivência cotidiana imediata, "vivenciamos o tempo como uma totalidade, que consiste num presente perene, abarcador, tanto do já acontecido como do que esperamos que venha a acontecer”. A pessoa que cada um é abrange quem ela já foi, quem ela está sendo e quem ela pretende ser. Assim, Rossi (2006) ressalta que essas três dimensões do tempo não são estanques, mas implicadas inexoravelmente.

É a temporalidade que permitiu a alguns profissionais, ao relatarem suas vivências como profissionais atuantes em Oncologia Pediátrica, remeterem-se às suas vivências passadas para retomar sua história desde o início da atuação junto a crianças e adolescentes com câncer. Mas, ao rememorarem o vivido, a memória não traz à tona uma lembrança estanque, mas abarca um recordar composto pelos significados que foram sendo atribuídos por cada um dos sujeitos às diversas experiências por eles vivenciadas ao longo desse tempo que transcorreu.

Nesse rememorar o passado, alguns participantes relataram ter enfrentado desafios no início da atuação neste contexto. Essas dificuldades foram anteriormente apontadas quando abordei a maneira preocupada de existir, porém estão sendo aqui retomadas, com intuito de alertar que o tempo de adaptação, por exemplo, a um novo contexto de trabalho, varia de indivíduo para indivíduo, dependendo de sua forma singular de experienciar o mundo, o tempo, o espaço, bem como de sua história de vida, do sentido encontrado na prática profissional, dos significados atribuídos ao cuidado, do vínculo estabelecido entre profissionais, pacientes e familiares, bem como dos recursos de enfrentamento que cada um possui.

Ao falar em adaptação, é preciso levar em conta a concepção fenomenológica de ser humano enquanto projeto, um ser em contínua construção. Assim, a adaptação não se restringe ao início da atuação em um novo contexto de trabalho, mas ela é contínua, sendo convocada sempre que novos encontros humanos acontecerem na trajetória desses 
profissionais. É preciso considerar esses encontros humanos também do ponto de vista das transformações, pois mesmo que os profissionais se conheçam e trabalhem juntos há vários anos, sempre haverá mudanças perpassando seus modos de compreender, agir e atuar.

Assim, Critelli (2007, p. 18) ressalta: “As ideias mudam, assim como mudam as sensações, as emoções, as perspectivas, os interesses, as lembranças... Mudam os modos de relação que os homens mantêm com as coisas, com os outros, consigo mesmos”.

O temporalizar também apareceu no relato do psicólogo Tadeu que contou sobre o início da atuação em Oncologia Pediátrica, ainda como estagiário de graduação. Com o objetivo de desfrutar de todos os ensinamentos que essa experiência poderia proporcionar para sua formação profissional, ele apresentou exigências em relação à própria forma de aproveitar aquele período.

Os profissionais também revelaram exercer a assistência voltada para o desenvolvimento da criança e do adolescente, mesmo que esses pacientes não venham a se curar e tenham a vida interrompida antes de chegarem à idade adulta. Logo, eles exercem o cuidado hoje, mas sem desconsiderar o passado da criança e sua história de vida e, também, sem deixar de lado o futuro deste indivíduo que pode vir a se curar. Os profissionais de saúde, neste caso, cuidam do "projeto", da possibilidade de os pacientes continuarem "sendo" e visam a esse contínuo movimento de vir-a-ser, indo além da visão do ser enquanto estático e determinado.

Porém, os profissionais conseguem também se aproximar da morte enquanto um fim para todos os seres humanos e, ao refletirem sobre a possibilidade de seus pacientes nãoserem-mais-no-mundo, os entrevistados fazem um movimento de lançar-se ao futuro, vislumbrando-o em sua totalidade, imbuído de restrições e possibilidades.

Ainda com relação à atenção a aspectos do desenvolvimento infantil, a enfermeira Eduarda, por exemplo, comentou sobre sua preocupação em relação às repercussões psicológicas e sociais do adoecimento e do tratamento no desenvolvimento sexual de crianças. Para se atentar a essas possíveis repercussões, a enfermeira precisou transcender o momento atual para se "lançar" ao futuro, o que só é possível pela capacidade humana de autotranscendência.

Vale pontuar que as vivências relacionadas à passagem do tempo são marcantes na história da humanidade, desde as épocas mais remotas. O ser humano sempre buscou objetivar sua marcha, analisando racionalmente o decorrer do tempo. As elaborações racionais possibilitaram ao homem estabelecer as dimensões do tempo - dia e noite; segundos, minutos 
e horas; passado, presente e futuro - refletindo sobre sua existência e planejando-a (FORGHIERI, 2009).

Porém, por mais que o ser humano procure controlar racionalmente o tempo, este continua a decorrer inexoravelmente, independente da vontade humana, mesmo que todos os relógios do mundo venham a parar e todos os calendários deixem de existir. E por maiores que sejam as suas conquistas para melhorar as suas condições de vida, o ser humano jamais conseguirá vencer a sua condição básica de ser finito, de ter de se defrontar, algum dia, com a sua morte (FORGHIERI, 2009, p. 43).

Para Vendruscolo (2006, p. 102), “independentemente de qualquer acontecimento, o tempo continua a fluir inexoravelmente e a nos remeter à condição de mortais. Não há como discorrer sobre a existência humana sem remetê-la à finitude”.

Forghieri (1984, p. 18) pontua que:

Somos vivos, mas também mortais. Vivemos e morremos, de certo modo simultaneamente, pois, a cada dia que passa, nossa existência tanto vai se ampliando quanto vai se tornando mais curta. No decorrer do nosso existir caminhamos a cada dia, para viver mais plenamente, assim como para morrer mais proximamente.

É preciso destacar que as elaborações racionais não deixam de ser importantes, pois fornecem parâmetros que nos permitem, até certo ponto, explicar e planejar nossa vida, o que é essencial para nos proporcionar alguma segurança. Porém, é necessário reconhecer que nossa existência é constituída por uma abrangência que ultrapassa tais elaborações (FORGHIERI, 2009).

\subsection{ESPACIALIZAR}

Racionalmente, o homem procura objetivar também o espaço, localizando e denominando os lugares, as coisas e as pessoas que se encontram no mundo. Esse mapeamento facilita a localização, o encontro com as pessoas, a busca pelos objetos e permite-lhe ter uma ideia da extensão do mundo. Porém, o espacializar não se limita a essas objetivações. O espacializar diz respeito ao modo singular com que cada um vivencia o espaço em sua existência, significando-o (FORGHIERI, 2009). 
Segundo Forghieri (2009), não encontramo-nos, apenas, fisicamente localizados num determinado lugar, mas expandimo-nos em nosso existir no mundo; um mundo que é constituído não apenas de sensações, mas de significações.

A vivência do espaço e a do tempo relacionam-se intimamente e são experienciadas com amplitude ou restrição, de acordo com a visualização de possibilidades e esperança de poder realizá-las, ou a restrição de perspectivas e desânimo por não vislumbrar meios de concretizá-las (FORGHIERI, 2009, p. 45).

Assim como o temporalizar, a maneira com que cada indivíduo experimenta o espaço de atuação profissional interfere na sua forma de adaptação ao seu contexto de trabalho.

Forghieri (2009, p. 44) explica que:

o ser humano, além de se encontrar concretamente num determinado lugar, tem compreensão de seu próprio existir no mundo, relativa tanto ao local e instante atuais como a outros vividos anteriormente e, também àqueles que deseja ou receia vir a experienciar. O nosso espacializar não se limita ao "estar aqui”, pois inclui o "ter estado lá” e o poder de vir a "estar acolá", reunidos numa compreensão global [...] O nosso espacializar é passível de tal "expansividade", que ultrapassa os limites do nosso próprio corpo e do ambiente concreto que nos circunda.

Os participantes, ao relatarem o início de seu trabalho em Oncologia Pediátrica, retomaram sua história neste contexto, relembrando vivências iniciais neste espaço. Alguns depoentes, inclusive, ressaltaram o quanto continuam vívidas em suas memórias, lembranças de pacientes que foram por eles assistidos há vários anos atrás, desde aqueles que sobreviveram até os que evoluíram a óbito. Essas recordações demonstram o quanto essas histórias passadas mantêm-se muito próximas no espaço presente.

Essa expansividade aparece também na capacidade desses participantes de, ao almejar a cura de seus pacientes, vislumbrar o "espaço existencial” que essas pessoas poderão vir a constituir futuramente, caso consigam ser de fato curadas. Assim, os entrevistados se lançam para experiências de maior amplitude existencial que ainda poderão ser vividas, em contraponto às restrições decorrentes do adoecimento e do tratamento que configuram a realidade do momento presente.

Além dessa expansividade, o ser humano é capaz de:

[...] vivenciar o distanciamento e a proximidade de locais, coisas e pessoas, independentemente de estarem, de fato, presentes, mas de acordo com seu modo de existir no mundo [...] aquilo que visualizamos existencialmente, 
como distante ou próximo, pode não ser o que está, objetivamente, a maior ou menor distância de nós (FORGHIERI, 2009, p. 45).

Outra forma de espacializar consiste no modo como esses profissionais se relacionam com o transcendente. No discurso de alguns participantes, fica evidente o quanto eles fazem uso da espiritualidade como recurso de enfrentamento e, para isso, conseguem manter-se próximos de entidades religiosas, que não se manifestam concretamente diante de si, mas estão presentes em sua mente.

Já o distanciamento aparece nas falas de alguns profissionais ao contarem sobre situações em que estão rodeados por colegas de trabalho, como em reuniões multidisciplinares, mas, ainda assim, experimentam distanciamento, já que nem sempre conseguem estabelecer trocas efetivas entre eles.

Além disso, os profissionais experimentam distanciamento quando se dão conta do cenário em que atuam: profissionais de diferentes especialidades, com diferentes crenças, concepções, significados e compreensões. O pensar diferente é experimentado pelos participantes como responsável por gerar distanciamento, sendo visto como impedimento para a compreensão mútua e, consequentemente, para uma atuação integrada. Essas divergências, criando abismos entre os colegas de trabalho, ficam ainda mais evidentes, ao notarmos que os entrevistados se sentem próximos e compreendidos pelos demais membros do grupo, justamente, quando há uma manifestação de concordância em relação à perspectiva de cada um, sendo suas condutas validadas e legitimadas. É importante ressaltar, porém, que esse validar aparece relacionado meramente a uma concordância, não englobando uma interação dialética. Sendo assim, o fato de os profissionais concordarem entre si não pode ser visto, necessariamente, como uma integração grupal, até mesmo porque, muitas vezes, revela sobreposição de um saber sobre o outro, sem a existência de intercâmbio entre as atividades e funções desempenhadas por cada especialidade. Além disso, vale considerar que as divergências podem representar oportunidades para construção de novos saberes, permitindo que cada profissional toque e seja tocado pela referência de cada um dos demais membros que compõem esse serviço, culminando, assim, em proximidade e integração.

Segundo Forghieri (2009), o espaço também pode ser experienciado com familiaridade ou estranheza, quando o indivíduo se sente acolhido e à vontade no ambiente em que se encontra em um dado momento, ou estranho e pouco acolhido num local em que não sabe como se situar. Tal fato pode referir-se não somente ao ambiente físico, 
concretamente presente, mas, também, ao modo de o indivíduo existir no mundo, ora permeado por sintonia e tranquilidade, ora experimentando preocupação e angústia.

Os participantes experimentaram o início da atuação em Oncologia Pediátrica com estranheza pela falta de conhecimento e familiaridade ao adentrar um novo ambiente de trabalho. Porém, aos poucos, puderam sentir-se familiarizados com esse espaço, conforme puderam conhecer e experimentar sentimentos de capacidade para desempenhar suas atividades. A familiaridade permitiu-lhes uma apropriação mais genuína da realidade, buscando formas de intervir nela, criando modos de articularem-se entre as restrições e as possibilidades do existir.

As falas da assistente de enfermagem Clara, da assistente social Natália e do psicólogo Tadeu evidenciam que eles experimentam o espaço do serviço de Oncologia Pediátrica com familiaridade. É essa familiaridade que permite a esses profissionais desempenharem seus trabalhos de forma criativa e flexível: eles não limitam sua atuação ao ambiente de trabalho, conseguindo oferecer suporte em diferentes locais do hospital e até mesmo nas casas das crianças doentes, de forma a expandir as possibilidades de cuidado.

Tem uns [pacientes] que [...] até na hora que eles estão 'ruim', eles te 'chama'. Tem muitos que eu vou lá em cima [ela refere-se à enfermaria, já que ela atua apenas na parte ambulatorial do tratamento], porque eles pedem para os pais me chamar e eu vou... vou lá em cima. Teve uns que eu já fui até na casa (Clara, assistente de enfermagem).

Tem dias que eu vou caminhar com o paciente no jardim e atendê-lo no jardim! É estar no movimento do outro desde que não me violente (Tadeu, psicólogo).

Mas vale relembrar, também, a fala da assistente de enfermagem Clara ao relatar que muitas de suas colegas de trabalho, assistentes de enfermagem, vivenciam a Oncologia Pediátrica como um espaço permeado por muito sofrimento, pelo fato de o tratamento requerer a realização de procedimentos invasivos e dolorosos em crianças e adolescentes.

Além disso, é preciso pontuar que diante da familiaridade possibilitada pela experiência de muitos anos de trabalho neste mesmo espaço e pela formação de um grupo de colegas que trilham esse mesmo caminho, juntos, há bastante tempo, alguns profissionais “veteranos” demonstram resistência a acolher os profissionais novatos e aqueles temporários (estagiários e residentes). A novidade proporcionada pelos novos membros parece ameaçar o espaço já constituído pelos membros “veteranos”, mobilizando estranhamento. E assim, visando a preservar a familiaridade, os profissionais podem correr o risco de adotar condutas 
que culminem em fechamento e rigidez, gerando um estreitamento das ações dentro daquilo que já é conhecido e legitimado e impedindo um reconhecimento do caráter mutável e fluido de qualquer relação humana, inclusive daquela estabelecida por pessoas que se conhecem e que convivem por longo tempo.

De acordo com Forghieri (2009, p. 46),

[...] ao espacializar, não apenas nos situamos concretamente em nosso ambiente circundante como, também, vivenciamos o nosso existir no mundo, ora com certa "elevação", amplitude, proximidade e familiaridade, ora com algum "rebaixamento", distância e estranheza; a intensidade dessa vivência varia de acordo com as oscilações que ocorrem em nossa maneira de existir que, umas vezes, é mais sintonizada e integradora, outras, mais preocupada e angustiante.

Assim, apesar de estar se tratando de um mesmo ambiente de trabalho, a forma com que cada profissional vivencia as experiências neste contexto e a maneira com que se relaciona com o ambiente e com as pessoas ao seu redor é muito particular.

\subsection{ESCOLHER}

Segundo Forghieri (2009, p. 48), a escolha decorre da liberdade:

[...] se o homem soubesse tudo com certeza, antes de decidir, não estaria sendo livre, mas determinado pela objetividade de seus conhecimentos, que lhe indicariam uma única escolha - a verdadeira, ou a mais acertada.

A questão das escolhas aparece no discurso dos profissionais de saúde relacionada ao momento inicial de ingresso no mundo do trabalho em contexto de Oncologia Pediátrica. Foi possível observar que, frente às dificuldades encontradas, alguns profissionais pensaram em renunciar à oportunidade de trabalho. Alguns participantes relataram momentos de questionamento em relação ao preparo para atuar junto a pacientes com câncer, além de se indagarem se estavam fazendo a escolha certa ao tomarem a decisão de atuar neste contexto.

Para Forghieri (2009), somente depois que uma escolha foi feita e concretizada é possível ter certeza do que foi assumido e do que foi renunciado. Vale ressaltar que, nesses casos, os profissionais demonstraram abertura para repensar seu caminho e, mesmo tendo 
optado por manter a escolha, essa postura de questionamento é essencial para que os mesmos possam resgatar, a cada dia, o sentido da atuação neste contexto.

Dessa forma, ao decidirem por continuar a percorrer esse mesmo caminho, os profissionais entrevistados demonstram que aquela escolha inicial continua sendo abraçada e reafirmada cotidianamente. Essa postura evidencia o caráter de abertura desses participantes, bem como a consciência que possuem de serem seres dotados de liberdade, logo, cuidam do outro porque escolheram e continuam escolhendo cuidar!

Com relação ao ingresso do médico Júlio no Serviço de Oncologia Pediátrica do HCFMRP-USP, ele contou que ao terminar a residência em Hematologia Clínica, ele recebeu uma proposta para atuar neste serviço, mas, inicialmente, a recusou, optando por escolher abrir o próprio consultório. Porém, em um segundo momento, demonstrou ter revisto sua decisão após um novo convite e, então, escolheu atuar, concomitantemente, nesses dois ambientes. Esse exemplo evidencia que, pelo fato de o homem ser capaz de olhar para si, refletir sobre a própria existência e por estar em contínua construção, lhe é possível rever o caminho percorrido, visando a mudar trajetos, rever antigas escolhas, abrir-se para outra forma de ver sua vida e para se aproximar de maneiras mais autênticas de existir.

De acordo com Forghieri (2009), a abertura para as possibilidades e projetos faz parte da nossa existência, propiciando experimentar a liberdade de manter nossos planos na mesma direção ou alterá-los. Mas, para isso, é necessário que o indivíduo não se mantenha, apenas, na conjectura e nos projetos, mas aja no sentido de concretizá-los. É necessário ir além dos projetos para realizar o próprio existir.

Voltando ao exemplo do médico Júlio, que pôde rever sua escolha de renunciar, inicialmente, à proposta de atuar no Serviço de Oncologia Pediátrica do HCFMRP-USP, abrindo-se para a possibilidade de abraçar a oportunidade que fora anteriormente recusada, é necessário ter em mente que nem sempre o ser humano possui a chance de voltar atrás e escolher algo que antes fora renunciado.

Forghieri (2009) pontua que, em algumas situações, é possível a alguém adiar algumas escolhas para momentos futuros, mas, frequentemente, as escolhas anteriores levam a caminhos que dificultam e, às vezes, até impedem a retomada de coisas que imaginaria ter renunciado apenas de forma temporária.

O psicólogo Tadeu ao contar sobre o motivo que o levou a optar pelo estágio em Oncologia Pediátrica ressaltou que essa possibilidade de atuação permitiria que ele unisse diferentes desejos e necessidades - atuar em hospitais, com crianças e adolescentes e com foco específico em Oncologia. No caso desse profissional, fica evidente que, em alguns 
momentos, é possível conciliar propostas igualmente desejáveis, enquanto em outros, uma escolha pode implicar na renúncia de outras possibilidades também interessantes.

Em outros casos, a opção de alguém por algo importante pode requerer a renúncia completa de outras coisas igualmente relevantes, o que pode gerar indecisão. Mas, é preciso ter coragem para se despojar de algo importante que gostaria de manter (FORGHIERI, 2009).

Vale pontuar que o horizonte de possibilidades existentes sempre coexiste com as restrições da realidade. Por isso, as possibilidades de escolha não são infinitas; é preciso escolher dentro de um leque de opções. Com relação ao câncer infantil, como já foi mostrado ao se abordar uma das características básicas do existir - o "mundo" circundante - não é possível escolher abrir mão da enfermidade, mas é possível encontrar, em meio às restrições que o adoecimento impõe, possibilidades de conviver com ele de forma mais leve, lembrando que esse "leve" também varia de um indivíduo para outro, dependendo do que lhe faz sentido.

A assistente social Natália, ao comparar sua atuação em Oncologia Pediátrica com o trabalho por ela realizado em um Centro de Atenção Psicossocial a usuários de álcool e outras drogas (CAPES - AD), acredita que o horizonte de possibilidades de usuários de drogas é um pouco mais amplo do que aquele enfrentado pelas crianças e adolescentes com câncer. Ela enfatiza que, apesar de ambas as situações gerarem muito sofrimento, o usuário de drogas pode escolher abrir mão do vício - não sem dificuldade e sofrimento- enquanto que o enfermo não pode escolher abrir mão da doença.

Segundo Forghieri (2009), a própria necessidade de ter de efetuar uma escolha entre várias possibilidades evidencia a limitação do ser humano, já que ele não pode escolher e concretizar, simultaneamente, todas as possibilidades existentes. É preciso escolher, mas, também, renunciar.

Pelo fato de a liberdade de escolher exigir renúncias e responsabilização pelas próprias decisões, ela é mobilizadora de angústia.

O indivíduo é livre para escolher, mas precisa se responsabilizar pelas escolhas que faz, mesmo sem ter a garantia de ter tomado a melhor decisão, sem saber se conseguirá concretizar, no futuro, sua escolha conforme a projetou no presente, e tendo que entrar em contato com a imprevisibilidade das consequências da mesma. Ao realizar uma escolha, a pessoa possui um conhecimento relacionado ao que já aconteceu e está acontecendo, mas depara-se, também, com a imprevisibilidade do que poderá vir a acontecer (FORGHIERI, 2009).

Com relação à responsabilidade perante as escolhas feitas, alguns indivíduos, temendo-a, optam por se eximir ou se acomodar em escolhas do grupo. Pude observar na fala 
da terapeuta ocupacional Ana que, ao comentar sobre algumas situações em que profissionais de saúde prorrogam a definição de Cuidados Paliativos a pacientes que já demonstram ausência de resposta ao tratamento, aparece uma crítica à conduta dos mesmos. Mas, ao mesmo tempo, a terapeuta ocupacional parece estar se eximindo desse papel atribuindo, unicamente aos médicos, a decisão de estabelecer ou não os cuidados paliativos para determinado paciente. Ela não parece buscar explicitar seu ponto de vista, promover uma discussão junto aos próprios colegas. Nesse caso, seria preciso investigar se a profissional busca eximir-se da responsabilidade que envolve assumir seu ponto de vista, ou se ela recua por não encontrar espaço, escuta e receptividade junto aos colegas.

[...] a equipe aqui da Oncologia Pediátrica é muito mais avançada em termos de cuidados paliativos do que outras equipes que pude ter contato. Eles [profissionais da Oncologia Pediátrica] aceitam muito mais e até pregam que, realmente, não se deve prolongar a vida a qualquer custo, que tem um limite, que tem que parar e dar alívio para o paciente. Acho que você pôde presenciar várias dessas discussões. Eles não estão na estaca zero mas, mesmo assim, às vezes, você percebe que essa decisão é um pouco adiada, o paciente já está dando indícios que não quer mais, o paciente pede: 'não quero mais fazer biópsia, não quero mais colocar sonda... e por que eles estão fazendo isso?'. E, às vezes, precisa do paciente ou do familiar falar, antes de eles tomarem a decisão, e tinha que ser o inverso (Ana, terapeuta ocupacional).

A nutricionista Denise, por exemplo, apresenta uma queixa sobre a falta de continuidade entre a sua assistência e aquela realizada pela nutricionista do ambulatório. Porém, não assume uma postura de se responsabilizar por tentar transformar essa assistência, por exemplo, mobilizando alternativas para conhecer essa profissional e o trabalho realizado por ela como forma de construir, conjuntamente, uma assistência contínua e integrada. Sendo assim, escolhe por manter a situação, adotando uma postura passiva de esperar que a transformação venha de fora.

Tem também uma dificuldade, em relação ao meu trabalho não ter continuidade no ambulatório, porque atuo na enfermaria e há outro profissional que atua no ambulatório e, às vezes, as condutas são divergentes. Eu não conheço a profissional do ambulatório [risos], ela não é minha colega, porque não é contratada pelo hospital, mas por um grupo de apoio... Então, as condutas divergem, às vezes, e então, a gente encontra dificuldade (Denise, nutricionista).

Forghieri (2009) explica que o momento anterior da escolha fornece a ilusão de liberdade total e permite experimentar a amplitude das possibilidades já que, antes de tomar uma decisão, as renúncias ainda não foram feitas. Essa ilusão anterior ao momento da escolha 
faz com que muitas pessoas se mantenham nessa situação, adiando o momento de efetuar uma escolha e de agir no sentido de concretizá-la, por acreditar que, assim, poderão manter a plenitude da liberdade. Outras se recusam a escolher por não se sentirem capazes de renunciar, por preferirem se acomodar à escolha do grupo e evitar qualquer assunção de responsabilidade e também por medo de verificarem que seus projetos não passavam de sonhos.

Apesar da angústia, da responsabilidade, dos riscos e da imprevisibilidade inerentes ao ato de escolher, o indivíduo é chamado a todo instante a tomar decisões. Enfrentamos imprevistos, consequências desagradáveis, nos frustramos, mas, em outros momentos, é possível experimentarmos satisfação pelo caminho escolhido (FORGHIERI, 2009).

A autora ressalta que quando um indivíduo consegue concretizar uma escolha de forma satisfatória, as realizações permitem ampliar as possibilidades e estas estimulam novas escolhas (FORGHIERI, 2009). Podemos pensar que as gratificações vivenciadas pelos profissionais em seu ofício conferem legitimidade às escolhas por eles realizadas, possibilitando aos mesmos uma maior abertura à compreensão de suas vivências, ampliando possibilidades e estimulando novas escolhas. Assim, os participantes conseguem se soltar à imprevisibilidade do futuro, mas com maior confiança na própria capacidade de tomar decisões.

Já o fracasso gera sentimento de frustração e desânimo, levando a reduzir, temporariamente, as possibilidades e a confiança na própria capacidade, além de ocasionar, também, uma desconfiança no mundo, que se mostra como impróprio e desfavorável à realização dos projetos dessa pessoa. O sentimento de frustração e paralisação na caminhada do existir serão maiores quanto maior for a importância desse projeto para o indivíduo (FORGHIERI, 2009).

Forghieri (2009) acredita, porém, que o ser humano é capaz de superar fracassos e dificuldades que permeiam o seu existir. Quando isso acontece, ele adquire uma compreensão mais completa de sua existência considerando não apenas a riqueza das possibilidades, mas, também, as limitações de si próprio e do ambiente. Dessa forma, “ele passa a abrir-se, novamente para suas possibilidades, já agora, de forma mais esclarecida e amadurecida” (FORGHIERI $^{15}$, 1986; FORGHIERI ${ }^{16}$, 1989, apud FORGHIERI, 2009, p. 51).

\footnotetext{
${ }^{15}$ FORGHIERI, Y.C. A vivência do tempo em situações significativamente frustradoras. Ciência e Cultura Suplemento, v. 38, n.7, p. 1048, 1986.

16 FORGHIERI, Y.C. Contribuições da Fenomenologia para o Estudo de Vivências. Revista Brasileira de Pesquisa em Psicologia, v.2, n.1, p. 7-20, 1989.
} 
Mas, mesmo quando um indivíduo é bem sucedido em sua escolha, ele tende a experimentar sentimentos de culpa, pelo fato de esta culpa ser inerente à existência humana, já que o homem sempre tem que renunciar a algo, nunca encontra condições de realizar todas as suas possibilidades (FORGHIERI, 2009).

Vale ressaltar que, pelo fato de o homem estar no mundo e estar em constante relação com pessoas e objetos - ser-no-mundo e ser-com - suas escolhas não acontecem de forma desconectada a seu contexto de vida, mas, ao contrário, ele recebe influências do mesmo.

Os participantes, por exemplo, definem sua forma de cuidar de crianças e adolescentes com câncer em função do encontro singular estabelecido com cada um dos pacientes, dependendo da relação entre a dupla profissional-paciente e sofrendo influência do contexto de trabalho bem como dos familiares dos pacientes e dos demais membros do serviço. Sendo assim, a escolha pela forma de desempenhar o cuidado, em determinado momento, é realizada de forma inédita a cada encontro, pelo fato de os profissionais flexibilizarem suas ações em prol de uma atenção mais pertinente às demandas de cada indivíduo que está diante deles para ser cuidado, não havendo uma fórmula de cuidar de crianças e adolescentes com câncer que seja válida para todos, podendo ser replicada.

A respeito dessa relação estabelecida entre profissional e paciente, vale retomar a dificuldade desses participantes ao se depararem com o fato de seus pacientes também serem dotados de liberdade de escolha, podendo tomar decisões a partir de suas perspectivas, inclusive, efetuando escolhas quanto à forma de cuidarem da própria saúde, a despeito dos esforços de controle empreendidos pela equipe. Nesses casos, os profissionais revelam experimentar sentimentos de frustração e impotência.

A partir das características básicas do existir propostas por Forghieri (2009) em seu enfoque fenomenológico da personalidade, descritas anteriormente, essa autora aborda a Saúde e o Adoecimento Existencial.

\subsection{SER-SAUdÁVEL E SER-DOENTE EXISTENCIALMENTE}

A livre abertura originária do ser humano às suas possibilidades e às restrições a essa abertura evidenciam o quanto a existência humana é paradoxal: o homem experimenta contentamento e tranquilidade, mas, também, aflição e contrariedades; é livre, mas também determinado por condicionamentos e circunstâncias variados; ama e odeia; convive com 
outras pessoas, mas, nem por isso, deixa de entrar em contato com sua própria solidão. São esses opostos que permitem ao homem atribuir o verdadeiro significado a cada um dos polos (FORGHIERI, 2009).

Esses paradoxos do existir ficaram evidentes nos relatos dos profissionais entrevistados que demonstraram experimentar dificuldades e frustrações, mas, também, realização profissional por atuarem em Oncologia Pediátrica. Esses opostos também apareceram, por exemplo, no contraponto entre vivências marcadas por impotência e experiências de conseguir ajudar, de forma efetiva, a pacientes e familiares.

Os paradoxos e riscos da existência fazem com que a existência seja permeada por incertezas e inseguranças. Essas inseguranças permanecem mesmo quando o indivíduo tenta apoiar suas escolhas em experiências passadas pois, mesmo que aja a partir do que já é conhecido, o presente é sempre uma abertura para o futuro que, por sua vez, é pura imprevisibilidade

Dessa forma, a insegurança associada à imprevisibilidade do futuro e às consequências de cada escolha tomada pelo homem, bem como os riscos, os obstáculos e as restrições ao existir de cada ser humano, fazem com que a abertura originária às suas possibilidades não seja realizada de forma fácil (FORGHIERI, 2009).

Para Forghieri (2009), em situações em que o indivíduo consegue se abrir às próprias possibilidades e, ao mesmo tempo, aceitar e enfrentar os paradoxos e restrições da existência, ele pode ser considerado um ser-saudável existencialmente. Ele é capaz de estabelecer, de forma eficiente, a articulação entre a amplitude e as restrições do existir.

Para Boss e Condrau ${ }^{17}$ (1976, p.14 apud FORGHIERI, 2009, p. 52):

A essência fundamental do homem sadio caracteriza-se, precisamente, pelo seu poder dispor, livremente, do conjunto de possibilidades de relação que lhe foi dado manter com o que se lhe apresenta na abertura livre de seu mundo.

A abertura inicial dos participantes deste estudo para experimentarem a atuação em um Serviço de Oncologia Pediátrica reflete a capacidade desses profissionais de se permitirem tentar equilibrar entre restrições e possibilidades, sem desconsiderar os desafios, os medos, os sentimentos de impotência e os próprios sofrimentos envolvidos na arte de cuidar de pacientes com câncer.

\footnotetext{
${ }^{17}$ BOSS, M. A; CONDRAU, G. As Descobertas Daseinsanalíticas: Base Teórica de uma Nova Psiquiatria. Daseinsanalyse. s/n, p. 14-22, 1976.
} 
Através da autotranscendência, da ressignificação e dos próprios recursos de enfrentamento, os profissionais de saúde conseguiram incorporar aspectos positivos à sua atuação profissional, desconstruindo algumas concepções iniciais, olhando para atuação neste contexto a partir de uma nova perspectiva.

O ser humano saudável, ao vivenciar momentos de restrição, conflitos e contrariedades sente-se confuso e aflito, mas consegue recuperar o envolvimento e a sintonia com seu sofrimento, atribuindo-lhe significado em sua existência e ampliando a compreensão de si e do mundo (FORGHIERI, 2009).

Assim,

[...] consegue recuperar a abertura às suas possibilidades e passa a ter condições de decidir entre elas, em qual pretende empenhar-se e quais as ações com as quais quer comprometer-se para resolver, superar ou aceitar uma determinada situação (FORGHIERI, 2009, p. 54).

Em contraponto, o ser-doente existencialmente:

só pode ser compreendido a partir do modo de ser-sadio e da constituição fundamental do homem saudável, não perturbado, pois todo modo de serdoente representa um aspecto privativo de determinado modo de ser-são (BOSS; CONDRAU ${ }^{18}$, 1976, p.14 apud FORGHIERI, 2009, p. 53).

Para Boss ${ }^{19}$ (1975 apud FORGHIERI, 2009, p. 53), o ser-doente existencialmente "não dispõe livremente e nem normalmente de todas as possibilidades de relações que poderia manter com o mundo”.

Há uma restrição na relação que o indivíduo existencialmente doente estabelece consigo mesmo e com o mundo. Porém, a simples ocorrência de restrições e conflitos na vida da pessoa não é suficiente para que ela seja considerada existencialmente doente, já que eles fazem parte da própria vida (FORGHIERI, 2009).

O adoecimento existencial só acontece quando as limitações e conflitos na vida da pessoa não são reconhecidos e enfrentados pela pessoa, à luz de suas múltiplas possibilidades. Assim, eles tornam-se ampliados e dominantes na vida do indivíduo. O indivíduo não consegue compreender o sofrimento para, então, ressignificar e atribuir um novo sentido para sua existência (FORGHIERI, 2009).

\footnotetext{
${ }^{18}$ BOSS, M. A; CONDRAU, G. As Descobertas Daseinsanalíticas: Base Teórica de uma Nova Psiquiatria. Daseinsanalyse. s/n, p. 14-22, 1976.

${ }^{19}$ BOSS, M. A Medicina Psicossomática e o Princípio de Causalidade. Hexágono, v. 2, n.1, p. 10-24, 1975.
} 
Há pessoas que não conseguem reconhecer e aceitar a insegurança, os paradoxos e as limitações de sua existência, sentindo-se confusas, desanimadas, revoltadas diante deles; há outras que se sentem tão ameaçadas e angustiadas, diante dos concretos e possíveis riscos de sua vida que procuram deles se esquivar, de algum modo. Essas pessoas passam a viver de modo restrito, empobrecido, minimizando a descoberta e a compreensão de si e do mundo (FORGHIERI, 2009).

Na percepção da autora (FORGHIERI, 2009, p. 53-54),

a diminuição de abertura às próprias possibilidades está profundamente relacionada à diminuição do envolvimento e sintonia da pessoa com as situações de grande sofrimento que ela experiencia, relacionadas a conflitos e restrições com as quais ela se defronta, sejam estes devido a circunstâncias pessoais ou externas e de natureza física, psíquica ou existencial.

Esta vivência de distanciamento de si e de seus semelhantes dificulta-lhe ou lhe impede, temporariamente, de se envolver nas situações e, consequentemente, de compreendêlas, atribuindo-lhes significados em sua existência (FORGHIERI, 2009).

Enquanto a pessoa permanecer distanciada da situação, não visualiza as peculiaridades desta e os recursos que possui para enfrentá-la; consequentemente, fica sem saber como agir para se libertar de seu sofrimento e prosseguir o curso normal de sua existência (FORGHIERI, 2009, p. 54).

Pude observar que os profissionais de saúde entrevistados, em alguns momentos, demonstraram capacidade de se aproximar de questões que mobilizam angústia, reconhecendo os paradoxos da existência, vislumbrando os riscos inerentes à mesma, bem como a facticidade de ser-para-a-morte que permeia a vida humana e, a partir disso, conseguiram aceitar essa condição, buscando potencializar as possibilidades existentes. Porém, em outros momentos, eles apresentam dificuldades em se aproximar de seus próprios limites, dificuldades e sofrimentos. Esse distanciamento aparece como forma de evitar o contato com a angústia mas, também, funciona como uma barreira ao próprio desenvolvimento, pois a aproximação com os obstáculos da existência é capaz de estimular que o indivíduo busque possibilidades existenciais em meio às restrições.

Os fatos que geram diminuição dos recursos pessoais ou restrições das condições externas na vida de uma pessoa podem se transformar num estímulo para que ele descubra e atualize suas possibilidades que, até então, ele não sabia que possuía ou não as havia valorizado suficientemente. Reconhecer as próprias limitações é o primeiro passo para 
transcendê-las, de algum modo, através da descoberta de suas outras possibilidades (FORGHIERI, 2009).

Forghieri (2009, p. 53) enfatiza que:

é necessário que a pessoa aceite as situações de sofrimento e com elas se envolva, para que consiga compreendê-las e ter, então, condições de se abrir às suas possibilidades de existir, que continuarão sendo amplas, apesar das restrições e sofrimentos que estiver vivenciando em determinado momento.

Já caminhando para o final deste capítulo, é possível evidenciar o quanto as características básicas do existir aparecem de forma inter-relacionada, já que não é possível falarmos, por exemplo, das maneiras de existir sem pensar no ser humano inserido no mundo, em contato com os determinismos do "mundo" circundante, em relação com as pessoas “mundo” humano - e voltado à compreensão dos próprios sentimentos - maneira racional de existir e “mundo” próprio. Esse indivíduo também está situado em determinado lugar em um período de tempo, apesar de vivenciar esse espaço e tempo de forma singular. Portanto, relembrando a justificativa da autora, a divisão em itens separados tem apenas função didática.

Por fim, pode-se dizer que, como seres humanos, os participantes deste estudo, enquanto continuarem existindo, poderão ir se conhecendo, conhecendo as pessoas e o mundo ao seu redor. A partir disso, irão formando sua própria identidade e influenciando na construção da identidade dos outros que convivem com ele. Durante suas existências, uma teia de significados irá sendo formada a partir de cada sentido atribuído às experiências vivenciadas e essa rede evidenciará particularidades de cada pessoa. Alguns desses sentidos permanecerão, outros muitos se alterarão ao longo da vida, recebendo uma cor, um brilho, uma intensidade que poderão variar, dependendo de novos conhecimentos que o indivíduo adquirir tanto de si quanto do mundo, bem como das influências que receberá dos demais sentidos atribuídos por seus semelhantes.

Os participantes deste estudo, em suas entrevistas, partilharam comigo parte dessa teia de sentidos, de forma que suas vidas pessoais e profissionais se entrelaçam e evidenciam os significados atribuídos por eles ao fenômeno ser-profissional-atuante-em-OncologiaPediátrica. Com certeza, alguns desses significados expressos serão transformados ao longo da existência desses profissionais que, enquanto seres humanos, estão em um contínuo vir-aser. As próprias vivências com pacientes, familiares e colegas de trabalho poderão contribuir para alterações nessa rede de significados. 
A existência desses profissionais continua seu caminhar, num jogo de paradoxos, restrições, dificuldades que se misturam com possibilidades, sonhos, criações, motivações...

Dessa forma, há sempre um horizonte de possibilidades descortinando a eles a cada manhã, de forma que a abertura desses participantes para a compreensão de suas vivências proporcionará mudanças, acomodações de significados, construções e reconstruções... Essa abertura para se abrir para um novo olhar permite reconhecer esses seres humanos como seres em projeto, sendo transformados a cada encontro, constituindo-se a partir do tempo.

É também essa abertura para perceber, compreender e significar suas experiências que permitirão aos profissionais vislumbrar e criar possibilidades no decorrer de seu existir, sempre levando em conta os próprios recursos e limitações, bem como os recursos e as limitações do ambiente de trabalho e a identidade e a singularidade de cada ser com quem se relacionam.

Assim, conforme a visão fenomenológica, esse estudo retrata apenas uma perspectiva deste fenômeno ser-profissional-atuante-em-Oncologia-Pediátrica; perspectiva essa que reflete o meu olhar, a minha intencionalidade, a intersubjetividade construída a partir do meu encontro com esses profissionais e do meu debruçar sobre seus relatos, bem como uma compreensão também relacionada ao meu momento e ao momento em que esses profissionais se encontravam em suas trajetórias existenciais. Portanto, não pretendi esgotar o fenômeno em sua essência, haja vista que a existência humana é um contínuo vir-a-ser.

De acordo com Muchail (1984), o desvelamento do ser dos entes não pressupõe necessariamente a esgotabilidade. O velamento pertence ao desvelamento, o que garante a inesgotabilidade do processo de desvelamento.

Heidegger explica essa possibilidade de o ser aparecer e mostrar-se utilizando uma palavra alemã que significa clareira. Porém, adverte que clareira não é sinônimo de luz, mas de possibilidade tanto de luz como de sombra, o jogo entre o claro e o escuro, entre o que se apresenta e o que se ausenta. Portanto, é necessário olhar para o não manifesto, o oculto, que conservam a inesgotável possibilidade de revelação (MUCHAIL, 1984).

Segundo Martins e Bicudo (2005), os significados têm como referência a totalidade experiencial das experiências vividas pelo indivíduo, totalidade essa que vai além da consciência explícita do indivíduo. Sendo assim, haverá sempre uma região não expressa que permanece oculta e, por isso, a pesquisa precisa estar em contínuo prosseguimento.

O discurso humano é necessariamente inacabado e incompleto, sendo os recursos para compreensão inesgotáveis (BRUNS, 2003). 
Rossi (2006) menciona que as proposições encontradas em um estudo fenomenológico devem ser reduzidas à condição de "ponto de vista" acerca do fenômeno e compreendidas enquanto perspectivas da consciência intencional do pesquisador na relação com os participantes do trabalho.

Turato (2005) alerta, ainda, que os estudos fenomenológicos não buscam uma generalização, pois não se voltam para quantificações ou estabelecimento de relações de causa-efeito. Logo, cabe ao leitor deste estudo examinar sua utilidade para compreender outras realidades e para aplicar em outras situações semelhantes. 


\section{DIÁLOGO COM A LITERATURA}

Neste capítulo procuro, através de algumas buscas assistemáticas à literatura, explorar alguns aspectos desvelados no contato que estabeleci com os profissionais, com o intuito de ampliar minha compreensão através de contribuições da área da saúde.

No encontro com os participantes deste estudo, pude perceber a importância que eles atribuem a um trabalho interdisciplinar, bem como o modo como vivenciam, pessoalmente, a experiência de cuidar da clientela em equipe. Suas falas revelaram que nem sempre eles conseguem, de forma efetiva, realizar esse trabalho conjunto. Segundo eles, as dificuldades para se atuar em equipe aparecem ligadas à falta de comunicação entre os colegas de trabalho, à quantidade de profissionais de diferentes especialidades envolvidos, suas diferentes crenças e valores, à estrutura física do hospital e à valorização dos médicos em detrimento dos demais profissionais. As dificuldades relatadas são coerentes com o que foi encontrado na literatura (CHIATTONE; SEBASTIANI, 1997; GALVÁN, 2007; KITAJIMA; COSMO, 2008; SCHRAIBER, 1999).

Senti necessidade, a partir dos relatos dos participantes, de buscar uma melhor conceituação do que seja um trabalho em equipe. No capítulo 4 - Sobre fatos: o quadro teórico, item 4.5 - Uma proposta de atuação em saúde: o modelo biopsicossocial e a interdisciplinaridade - abordei esse aspecto ao diferenciar equipe interdisciplinar de equipe multidisciplinar. Já, aqui, percebi a importância de se fazer um movimento ainda anterior, buscando compreender de uma forma ampla, não mais voltada apenas para a atuação em saúde, o conceito de trabalho em equipe.

Segundo Peduzzi (2001, p. 104), na literatura são escassas as definições disponíveis sobre o que seja um trabalho em equipe, sendo que:

a noção de equipe multiprofissional é tomada como uma realidade dada, uma vez que existem profissionais de diferentes áreas atuando conjuntamente, e a articulação dos trabalhos especializados não é problematizada.

Segundo Robbins (2008), há diferenças entre as denominações ‘grupo’ e ‘equipe’. Um grupo é formado por duas ou mais pessoas que interagem para compartilhar informações, tomar decisões e para se ajudarem mutuamente no desempenho de tarefas relativas às suas distintas áreas de atuação. O desempenho do grupo envolve a somatória de todas as contribuições individuais de seus membros, não extrapolando essa contribuição individual e 
não havendo uma sinergia positiva. Já nas equipes, existe uma sinergia positiva mediante um esforço coordenado; neste caso, os resultados extrapolam a soma das contribuições individuais.

Nas equipes, diferentemente do trabalho em grupo, a realização das atividades dependerá mais dos esforços coletivos do que dos esforços individuais. Além disso, o objetivo de trabalho é comum a todos, a relação de trabalho estabelecida com a empresa é formalizada e clara, a responsabilidade e o resultado final, seja de sucesso ou fracasso, são compartilhados por todos os membros (ALBUQUERQUE; PUENTE-PALACIOS, 2004).

Para Parker (1994), um grupo de pessoas não configura uma equipe. A equipe pressupõe alto grau de interdependência dos componentes da mesma, destinada para a realização de uma tarefa ou meta. Neste caso, as pessoas concordam com a meta a ser alcançada e acreditam que só é possível atingi-la através do trabalho em equipe.

Para Campos (1992, p. 256), uma atuação só é considerada como "trabalho em equipe”:

quando opera de modo cooperativo, convergindo seus objetivos para uma dada situação, de forma a haver complementaridade e não soma ou superposição. Operar de modo cooperativo, por sua vez, não implica em trabalhar sem conflitos. A presença destes é inevitável e universal.

Machado (1998) define equipe como um sistema de relações dinâmicas formado por um grupo de pessoas capazes de se identificar e serem identificadas dentro da organização como pertencentes a um grupo relativamente estável. Esses indivíduos compartilham técnicas, regras, procedimentos e responsabilidades, com o foco em alcançar objetivos comuns.

Nas falas dos participantes fica evidente que eles se identificam como integrantes de uma equipe e são vistos, segundo minhas próprias vivências na área, pelos demais profissionais da instituição como “equipe da Oncologia Pediátrica”. É evidente que há um objetivo comum na atuação de todos os profissionais de saúde - a oferta de atendimentos de qualidade a pacientes com câncer e a seus familiares e, para atingir esse objetivo, os participantes compartilham regras e responsabilidades. A fala da assistente social Regina ressalta seu olhar para uma responsabilidade grupal:

não sou eu, enquanto assistente social, somos nós enquanto equipe! (Regina, assistente social).

O fato de alguns desses profissionais, por exemplo, da equipe de enfermagem e médicos residentes de primeiro ano, desempenharem seus trabalhos segundo a dinâmica de 
rodízios, estando a cada mês em um setor diferente da Pediatria, parece não romper com o critério de certa estabilidade proposto por Machado (1998), como foi mostrado anteriormente, já que muitos dos profissionais atuantes no serviço de Oncologia Pediátrica realizam seu trabalho de forma fixa neste setor do HCFMRP-USP.

Porém, em alguns momentos, a atuação integrada e complementar visando a um objetivo mútuo sofre rupturas e culmina em menor integração e maior sobreposição, devido aos obstáculos relatados pelos próprios participantes. Nestas ocasiões, os profissionais parecem vivenciar situações em que deixam de integrar, de fato, uma equipe, para compor um grupo, num jogo dinâmico marcado por períodos ora de maior, ora de menor integração. É interessante observar que, para os autores mencionados anteriormente, o trabalho multidisciplinar - diferentemente do trabalho interdisciplinar - por não promover integração de saberes, mas superposição, impedindo o aparecimento de uma sinergia positiva entre os membros do grupo, não poderia ser denominado “trabalho em equipe”, por não configurar, de fato, uma atuação em equipe.

Porém, assim como pontua Moscovici (2003), um grupo aspira a transformar-se numa equipe quando começa a prestar atenção na sua própria forma de operar e procura resolver os problemas que afetam seu funcionamento, englobando ciclos de percepção de fatos, planejamento de ação e resolução de problemas. No contato com os entrevistados, fica clara a existência de um movimento de questionamento do caminho trilhado, demonstrando não só capacidade de percepção das dificuldades enfrentadas, como também promoção de mudanças rumo a um trabalho mais integrado, o que fica evidente na fala da assistente social Natália:

A equipe [da Oncologia Pediátrica] [...] cada vez se preocupa em melhorar mais! Quando a gente percebe que tem alguma coisa que não está legal, a gente pensa, para. Acho que todo mundo se implica muito, se envolve muito e, talvez por isso, o trabalho da 'Onco', da equipe daqui, está nesse nível diferenciado (Natália, assistente social).

Outra questão importante é que alguns entrevistados revelaram que o fato de o serviço de Oncologia Pediátrica do HCFMRP-USP ser composto por profissionais que atuam juntos há mais de uma década, favorece a integração entre os colegas. Por este mesmo caminho, uma das entrevistadas traz à tona as dificuldades de alguns profissionais recém-chegados ao serviço, que buscam na medicação a ferramenta para superar os desafios da assistência neste contexto. Fica evidente que um bom vínculo com os colegas de trabalho e a experiência profissional são fatores que auxiliam no enfrentamento dos desafios que permeiam a atuação em saúde. Porém, é necessário refletirmos sobre formas de acolhimento aos novatos, 
desenvolvendo estratégias de suporte aos mesmos, para que o período de adaptação a esse contexto até então desconhecido, não seja tão prolongado, dependendo de vários anos de experiência na área. Porém, para acolher os novatos, é essencial que haja um trabalho junto com os profissionais “veteranos”, já que alguns deles, revelam em seus discursos, experimentar a chegada de novos profissionais com incômodo, por romper com a estabilidade e o equilíbrio conquistados através de vários anos de trabalho com os mesmos colegas.

Com relação à importância do bom vínculo entre colegas de trabalho, antes de esse estudo ser realizado, minhas pré-concepções me dirigiam para uma percepção de que os profissionais de saúde apresentavam um movimento natural de buscar apoio junto a seus colegas, como forma de suporte para lidar com aspectos difíceis associados aos seus trabalhos. Porém, a terapeuta ocupacional Ana, relatara que, na prática, os próprios colegas de equipe optam por restringir as reuniões semanais na enfermaria apenas para discussão de casos clínicos.

[...] a equipe [da Oncologia Pediátrica] não é disposta a sentar e falar dos assuntos difíceis... as reuniões ficam mesmo para discussão de casos e voltadas para os pacientes. Não vejo a equipe disposta a resolver problemas internos e se ajudar neste sentido, pelo menos, multiprofissionalmente falando (Ana, terapeuta ocupacional).

A fala dessa profissional permite pensar que os profissionais podem apresentar dificuldades para reconhecer as próprias necessidades, o que pressupõe a importância de se implementar projetos de preparação e treinamento dos próprios profissionais para que eles consigam reconhecer suas demandas de apoio pelos colegas. Além disso, sua fala também permite pensar que pode haver não só dificuldade de reconhecimento das necessidades, mas também falta de interesse ou falta de liberdade para tematizar suas dificuldades e sentimentos junto aos demais colegas. Logo, passa a ser essencial que além do treinamento para reconhecimento das próprias necessidades, haja orientações com o objetivo de auxiliar esses profissionais a desenvolverem iniciativas para efetivar a busca por esse auxílio e abertura para acolhê-lo. E ainda, é importante fazer uso desses treinamentos como forma de orientar e capacitar os profissionais de saúde para se tornarem referência uns para os outros.

Com relação à experiência profissional, Silva et al. (2010) alertam que um primeiro emprego ou a mudança de posição no trabalho despertam a necessidade de novas atitudes e capacidades e, por isso, podem ser vivenciados como um desafio ou como uma ameaça. A maneira como a pessoa irá experimentar esta situação, como uma ameaça ou como um desafio, influenciará nas estratégias que irá selecionar para enfrentar a situação. Aqueles 
indivíduos que se sentem desafiados possuem autoestima alta, provocando sentimentos de controle da situação e, desta maneira, desenvolvem capacidades para superar a situação estressante.

A maioria dos trabalhos pesquisados trata da experiência profissional associada à idade do trabalhador e não ao vínculo com determinada atividade por um longo período.

Não há consenso na literatura sobre o fato de o enfrentamento mudar de acordo com a idade. Alguns estudos mostraram que os idosos se tornam mais passivos, enquanto outros trabalhos revelaram que os esforços de enfrentamento aumentam com a idade, devido ao uso de mecanismos de defesa mais maduros, tais como o altruísmo (ALDWIN; GILMER ${ }^{20}, 2003$ apud FONTES; NERI; YASSUDA, 2010).

Para Silva e Andreoli (2008), pouca experiência clínica e atitudes agressivas, dogmáticas e arrogantes de profissionais geram dificuldades para o desenvolvimento de uma comunicação e uma relação mais próxima com pacientes.

Meleiro (2001) defende a importância da maturidade para o exercício da profissão médica e acredita que ela pode ser identificada por aspectos como humildade, autocontrole, autoconfiança, sabedoria, experiência e integridade, que tendem a aumentar com a idade e com a experiência de vida. Vale pensar nessas colocações não apenas em relação aos médicos, mas estendendo aos demais profissionais de saúde. Porém, a autora acrescenta que a competência social madura não decorre somente do aprendizado via experiências de vida, mas também de exemplos de outras pessoas e das vivências de mentores. Por isso, sugere a inclusão de disciplinas como Psicologia Médica e Ética Médica nos cursos de Medicina e critica as melhores escolas de Medicina do país por negligenciarem questões relativas à saúde mental, tanto com relação a aspectos teóricos como interpessoais.

Para Andreis, Chitero e Silva (2008) a maturidade, bem como atitudes de respeito mútuo, flexibilidade, empatia e persistência são relevantes, também, por permitirem o alcance de uma atuação integrada e coerente entre profissionais de um serviço de saúde.

Segundo Fontes, Neri e Yassuda (2010), o enfrentamento de estressores pode ser um processo muito mais relacionado a sentir-se capaz de lidar com os estressores e a atuar como um agente diante das condições adversas do que como um processo dependente da idade ou do uso de determinada estratégia.

\footnotetext{
${ }^{20}$ ALDWIN, C. M.; GILMER, D. F. Health, illness, and optimal aging: Biological and psychosocial perspectives. Thousand Oaks, CA: Sage, 2003.
} 
Dessa forma, a troca entre profissionais experientes e profissionais novatos pode contribuir para o desenvolvimento de recursos de enfrentamento eficazes para esses últimos, sem que os mesmos tenham que ficar a mercê de vários anos de experiência profissional.

Além disso, torna-se necessário repensar a grade curricular não só dos futuros médicos, mas também dos demais cursos de saúde, com o objetivo de prepará-los, não só do ponto de vista técnico, mas, também, do ponto de vista ético e emocional para as situações com as quais os mesmos irão se deparar no cotidiano de sua prática profissional. Porém, como alerta Casate e Corrêa (2005), não basta a inclusão de conteúdos na grade curricular dos cursos; é necessário que haja um movimento de repensar a forma com que eles são articulados à prática para que possam fazer sentido para os estudantes.

Nas entrevistas realizadas, alguns profissionais de saúde comentaram sobre a formação acadêmica que receberam. Muitos deles relataram descompasso entre as orientações recebidas durante a graduação e as exigências práticas, bem como o fato de terem sido instruídos a controlar suas emoções e evitar envolvimento com seus pacientes.

Andreis, Chitero e Silva (2008) confirmam a existência de um processo de dessensibilização associado à busca de um controle das emoções. Além disso, alertam sobre a valorização do conhecimento técnico como fator primordial para a atuação e contratação de profissionais, sem haver preocupação com o preparo emocional dessas pessoas que atuam em saúde.

Para Silva et al. (2010), ao saírem da graduação e adentrarem ao mercado de trabalho, os profissionais de saúde tendem a experimentar situações estressantes, pelo fato de se depararem com as discrepâncias entre o aprendizado adquirido na academia e a realidade encontrada no seu ambiente de trabalho. Na enfermagem, este conflito foi descrito como “choque de realidade".

Esperidião e Munari (2004), ambas as professoras de Ensino Superior na área de saúde, alertam que a formação em saúde não tem destinado atenção a aspectos que favoreçam o fortalecimento emocional dos futuros profissionais de saúde. Segundo elas, há uma evidente desconsideração dos agravos produzidos pelas situações ansiogênicas a que os alunos em formação se veem expostos rotineiramente. As autoras acreditam que a humanização da assistência requer um movimento anterior de humanização da formação desse aluno, que será um profissional no futuro. Segundo elas:

Debruçar sobre esses elementos, com vistas ao ensino centrado na pessoa, abarcando não somente a competência técnica e racional do aluno, mas sua totalidade, concebendo-o como alguém que possui atributos pessoais e que 
experimenta diversos sentimentos quando implementa suas ações profissionais, torna-se um investimento fundamental, quando se busca o ser integral e integrado naquilo que faz (ESPERIDIÃO; MUNARI, 2004, p. 333-334).

Dessa forma, as dificuldades relatadas pelos entrevistados são muito pertinentes à situação com que os mesmos se deparam e para as quais não foram adequadamente preparados em suas formações.

Além disso, a formação voltada para a cura das doenças é responsável, muitas vezes, pelo despreparo de profissionais para lidar com situações em que pacientes estão fora de possibilidades terapêuticas, mobilizando-lhes sentimentos de impotência, frustração e desânimo; sentimentos esses presentes nas vivências dos participantes deste estudo, conforme relatos deles próprios.

Os profissionais de saúde são sempre desafiados ao entrarem em contato com a morte, já que foram treinados para a melhora e a cura dos pacientes. A morte é vista como uma inimiga a ser vencida, uma derrota e um fracasso nas condutas terapêuticas. Segundo Angerami-Camon (2000, p. 133) “morrer é extremamente ameaçador ao ideal de cura e vida, ameaçando as funções dos profissionais de saúde (como o próprio nome indica)”.

A dificuldade de lidar com a morte do outro é doloroso para o profissional, já que encarar a morte do outro faz com que ele se confronte com a sua própria possibilidade de morte. Porém, aceitar sua condição de ser finito é essencial para compreender e escutar pacientes e familiares. O fato de negar essa condição não diminui a angústia do profissional, mas faz com que aumentem os medos e os mecanismos de defesa, dificultando a atenção dos profissionais às necessidades de cada paciente (ANGERAMI-CAMON, 2000).

Os profissionais de saúde entrevistados revelaram, também, contato com aspectos da assistência que podem comprometer a qualidade de vida dos mesmos, por gerar sofrimento psíquico. Logo, as dificuldades vivenciadas pelos profissionais de saúde não se restringem ao período inicial de inserção neste contexto de trabalho. Os aspectos mencionados são coerentes com o que foi encontrado na literatura: jornada de trabalho prolongada; contato intenso com dor, sofrimento e morte; sentimentos de culpa, frustração e impotência frente às situações de fechamento de prognóstico e de perda de pacientes; limitações do conhecimento científico (ANDREIS; CHITERO; SILVA, 2008; GOMES; LUNARDI FILHO; ERDMANN, 2006; MENZANI; BIANCHI, 2005). É evidente que o cotidiano de trabalho desses participantes é marcado pela imprevisibilidade e pela instabilidade, características capazes de gerar sentimentos de vulnerabilidade, insegurança e fragilidade, bem como de desencadear 
sintomas de estresse, ansiedade e depressão. Vale relembrar, também, que essas condições mencionadas tornam esses profissionais vulneráveis à Síndrome de Burnout, que causa prejuízos na qualidade da assistência oferecida.

De acordo com Andreis, Chitero e Silva (2008), as situações podem ser consideradas psicologicamente difíceis quando despertam diferentes sentimentos nas mais variadas intensidades, porém sempre envolvendo algum grau de sofrimento psíquico, estresse e esforço adaptativo. A identificação de agentes estressores depende de fatores individuais, tais como interpretação pessoal e recursos de enfrentamento. Portanto, a atuação em Oncologia Pediátrica é experimentada de forma muito singular por cada profissional.

Para Marqueze e Castro Moreno (2005), um dos aspectos que interfere na adaptação ao trabalho está associado à satisfação que o profissional encontra em desempenhar essa atividade.

Neste sentido, é interessante pensar em recursos que minimizem a insatisfação no trabalho, tanto pelo fato de esta causar prejuízos à saúde física, mental e social do indivíduo, acarretando problemas à organização e ao ambiente de trabalho, como também pelo fato de a satisfação contribuir para o melhor enfrentamento de situações difíceis.

Especificamente, a respeito do trabalho em enfermagem, os autores Gomes, Lunardi Filho e Erdmann (2006) revelaram que essa atuação está associada ao prazer quando permite o desenvolvimento das potencialidades humanas, libera o trabalhador para criar e executar o próprio trabalho, favorecendo os laços cognitivos e técnicos com o resultado de sua atividade, levando-o à satisfação e à conscientização de seu papel, não só para a organização na qual trabalha, mas, também, para a sociedade. Ao contrário, quando o trabalho tem por fim único a mercadoria ou o serviço prestado, pode reprimir as potencialidades humanas e, consequentemente, gerar alienação, estranhamento, insatisfação, angústia e sofrimento psíquico.

Para Silva e Marziale (2000), a insatisfação também aparece ligada aos seguintes fatores: baixa remuneração e incentivos, poucas oportunidades de promoção, inexperiência dos supervisores, relações interpessoais insatisfatórias, ambiguidade de papéis e grande número de trabalhadores em uma única unidade.

Marqueze e Castro Moreno (2005) fazem algumas orientações no sentido de amenizar os problemas decorrentes da insatisfação: adaptação do ambiente de trabalho ao indivíduo; aumento das oportunidades para atividades de lazer, esporte e relaxamento; atividades sociais; programas de interação social; adequação do salário à função exercida; plano de carreira; cumprimento das leis trabalhistas; formação de uma equipe de saúde ocupacional para avaliar 
as situações de risco, adotando medidas preventivas e de apoio, entre outras. Ressalta, porém, a necessidade de uma participação ativa dos trabalhadores em todo o processo, que deve ser realizado através de ações interdisciplinares e de alcance coletivo com o intuito de atuar na manutenção e na promoção da saúde do trabalhador.

É interessante observar que, de maneira natural, os participantes do presente estudo fazem uso de alguns recursos de enfrentamento orientados pela Sociedade Internacional de Oncologia Pediátrica como forma de prevenção da Síndrome de Burnout, tais como: definição de limites pessoais em termos de tempo e energia, evitando envolvimento excessivo; utilização de mecanismos para controlar estressores do trabalho dentro de hospital; uso de sistemas de apoio formal e informal; compartilhamento de necessidades com colegas e supervisores; períodos de lazer para propiciar que volte para o trabalho bem fisicamente e mentalmente; religião ou alguma forma de apoio espiritual (KIRSCHBAUM e SILVA, 1998; SIOP, 2000).

Silva e Andreoli (2008) orientam que as dificuldades sentidas pelos profissionais de saúde devem ser entendidas a partir da compreensão dinâmica da relação estabelecida entre todos os personagens desse cenário, incluindo os pacientes, seus familiares e os próprios profissionais.

Além disso, as dificuldades vivenciadas na prática da assistência em saúde não podem ser olhadas sem considerar a instituição hospitalar em que esses profissionais trabalham.

De acordo com Amorim, Lopes e Bruscato (2004, p. 195):

a equipe está inserida no conjunto de normas e rotinas da Instituição e é pressionada por aspectos institucionais como a grande demanda de pacientes, a eventual falta de recursos materiais, o pouco tempo destinado à consulta, o tipo de paciente atendido e os problemas de vida que ele traz.

Os participantes revelaram sentimentos de desamparo em relação às suas expectativas de que a instituição destinasse um olhar para seus funcionários, visando a promover formas de cuidado aos mesmos. A fala de um dos participantes, o psicólogo Tadeu, revelou a importância de uma atitude ativa dos próprios profissionais de saúde em relação ao próprio cuidado. De fato, é preciso reconhecer as próprias dificuldades e as limitações do contexto de atuação, para que então, a partir da percepção das restrições, seja possível mobilizar possibilidades. Nesse sentido, construir as próprias alternativas pode ser um meio viável de autocuidado frente à ausência de um cuidado que poderia também vir de fora, mas que não tem se manifestado. 
Porém, é interessante apontar que, apesar de os participantes revelarem essa falta de suporte da instituição hospitalar em que atuam, a imagem positiva que essa mesma instituição tem perante a sociedade é capaz de gerar satisfação para alguns eles. É como se, em alguns momentos, eles se permitissem mergulhar nessa imagem que é transmitida, alimentando-se dela e deixando um pouco de lado a realidade de desamparo com que se deparam cotidianamente.

O sentimento de pertença a um grupo e a um serviço reconhecido por sua qualidade parece contribuir, também, para a satisfação dos profissionais. Além disso, o reconhecimento recebido pelos pacientes e seus familiares bem como o sentimento de autonomia para o desenvolvimento do próprio trabalho representam outros fatores importantes revelados como propiciadores de satisfação pelos entrevistados.

Segundo Andreis, Chitero e Silva (2008), o estímulo à participação ativa e o reconhecimento da contribuição de cada funcionário favorecem à comunicação e à busca de integração grupal, o que proporciona melhoria no ambiente de trabalho. Além disso, o envolvimento da liderança, bem como o reconhecimento da instituição interferem de maneira positiva no alcance de resultados e no engajamento da equipe.

Para Silva e Marziale (2000) justamente a falta de reconhecimento e de autonomia são fatores que podem gerar insatisfação no trabalho, além de altas taxas de absenteísmo e rotatividade de profissionais de saúde.

Chamou-me a atenção, na fala dos profissionais entrevistados, o sentimento de responsabilidade de cuidar do outro, de forma que todos parecem abraçar essa causa, mobilizando-se e mobilizando os colegas para olhar ao próximo, indo muito além do desempenho de uma função. É notório o envolvimento, a entrega, a disponibilidade dos entrevistados ante aqueles de quem cuidam.

Segundo Nucci e Perina (2008), o paciente e seus familiares, ao chegarem ao hospital, trazem consigo sua história de vida com sofrimentos, alegrias, superações, experiências e expectativas. Nesse cenário, torna-se importante a presença de profissionais que ofereçam suporte para conter angústias, que ajudem essas pessoas doentes e seus familiares a darem sentido a tudo o que estão passando e que facilitem o processo de enfrentamento da realidade vivenciada.

O Ministério da Saúde (2009) também orienta sobre a importância de os profissionais envolvidos irem além do tratamento ao câncer em si e destinar atenção aos aspectos sociais da doença, já que a criança e o adolescente doentes devem receber atenção integral, inseridos no 
seu contexto familiar, destinando o foco desse tratamento não somente à recuperação biológica mas, também, ao bem-estar e à qualidade de vida do paciente.

Apesar disso, Angerami-Camon (2000), Lima et al. (2007), Pinho e Santos (2008) trazem à tona que o cuidado em saúde ainda é marcado pela dificuldade que os profissionais de saúde apresentam para prestar assistência levando em conta essas orientações.

Porém, pude observar que, diferentemente do que a literatura traz como predominante no cuidado em saúde, os participantes deste estudo demonstraram capacidade de olhar os pacientes de forma integral, evitando a fragmentação corpo-mente e indo além do foco apenas no adoecimento físico. Além disso, demonstraram percepção aguçada das necessidades singulares tanto dos pacientes como de suas famílias, levando em conta a maneira com que cada um lida com o adoecimento a partir dos recursos pessoais, história de vida, crenças e valores. A literatura ressalta a importância dessa atenção às necessidades singulares de pacientes e familiares como forma de auxiliá-los no processo de adaptação e enfrentamento à situação de adoecimento e tratamento (ANDREOLI, et al., 2006; AZZI; ANDREOLI, 2008; MEDEIROS; ANDREOLI, 2008; TONETO; GOMES, 2005).

Podemos pensar que essa disponibilidade evidente nas falas dos profissionais se reflete na alta adesão de pacientes ao tratamento desta instituição e na confiança que os mesmos depositam no serviço, como pude observar durante o período que atuei neste setor do HC. Além disso, é possível considerarmos, também, que esse movimento de mudança em relação a um cuidado mais humanizado possa ser reflexo de pesquisas na área que veem alertando há bastante tempo sobre a importância desse olhar global aos pacientes e também às suas famílias.

Segundo um levantamento bibliográfico realizado pelas autoras Casate e Corrêa (2005), desde o final da década de 50 já haviam estudos que ressaltavam a importância da humanização em saúde. Trabalhos publicados nesse período enfatizavam situações desumanizantes experimentadas no contexto hospitalar, dentre elas: longas esperas, adiamento de consultas e exames, falhas nas estruturas físicas, despersonalização do paciente, falta de privacidade, de preparo psicológico e de informação para os pacientes e falta de ética. Com relação aos profissionais de saúde, esses estudos já mencionavam algumas condições do contexto de trabalho que representavam fontes de sofrimento para os trabalhadores, entre elas: baixos salários, dificuldade na conciliação da vida familiar e profissional, sobrecarga de atividades, contato constante com pessoas sob tensão, ausência de recursos humanos suficientes, falta de oportunidade para aperfeiçoamento profissional, além da racionalização e 
mecanização do trabalho responsáveis por gerar uma fragmentação da relação profissionalpaciente, impedindo o profissional de visualizar seus pacientes de forma global.

Com relação à valorização desse olhar ao paciente como um todo, Casate e Corrêa (2005) pontuam que orientações em relação à importância desse cuidado, voltado para as dimensões biopsicossociais de pacientes, existem desde a década de 70, porém, ainda hoje, o saber nem sempre se concretiza no fazer. Estudos mais recentes, da década de 90, defendem que um processo de humanização requer a capacidade de oferecer condições para que o doente seja um participante ativo no seu processo de tratamento. A questão da formação desses profissionais foi pouco abordada por esses estudos; quando analisada, tematizam tanto sobre a necessidade de alterações na grade curricular com o intuito de incluir disciplinas com ênfase nas ciências sociais e humanas, como também defendem o foco na relação professoraluno, como forma de ajudar o estudante a experimentar, já em sua formação, a relação sujeito-sujeito e não sujeito-objeto no contato com seus professores. Alguns trabalhos enfatizam também a importância de se destinar atenção para a organização do serviço de saúde, no sentido de investir na estrutura física e de revisar os métodos administrativos aplicados pela mesma, bem como de considerar as condições de trabalhos dos profissionais de saúde. Nesse sentido, a humanização em saúde requer mudanças na forma de olhar o paciente, além de investimentos na formação e treinamento do profissional de saúde e de investimentos na estrutura física da instituição (CASATE; CORRÊA, 2005).

De fato, é essencial que esses profissionais estejam atentos às necessidades singulares de pacientes e familiares e disponíveis para prestar-lhes acolhimento e orientação, levando em conta o indivíduo como um todo. Porém, é preciso questionar se todas essas atribuições e expectativas não causam a esses profissionais de saúde uma sobrecarga que os mesmos não estão preparados para lidar e não possuem recursos para administrar. É preciso atentar para as expectativas tanto de pacientes, familiares, instituição de saúde como também para aquelas dos próprios profissionais de saúde, já que todos os envolvidos podem partir de idealizações do que seja o papel de um bom profissional, muitas vezes, desvinculadas das possibilidades reais de prestação da assistência.

O engajamento, a gratificação pelo contato, o aprendizado com pacientes com câncer, bem como o significado que cada participante do presente estudo encontra na sua prática profissional funcionam como um sustentáculo, auxiliando-o no enfrentamento de situações consideradas difíceis. Entretanto, ao mesmo tempo, esse mesmo envolvimento e o engajamento, são responsáveis pelo sofrimento experimentado por esse profissional em situações em que se depara com o sofrimento e a perda de pacientes. 
Uma percepção nova e surpreendente que tive em relação a esses profissionais foram de pessoas carentes de serem vistas, ouvidas e consideradas em suas necessidades. Foi notável a disponibilidade dos participantes para acolher minha proposta, todos eles demonstraram abertura para abrir seu "baú de histórias” com muita generosidade e confiança neste trabalho e, a maioria deles, no final do encontro, agradeceu a oportunidade, relatando ter experimentado bem-estar por falar de si e de suas experiências.

Penso que os profissionais têm lidado com uma carga enorme de exigências, tanto de si mesmos como de pacientes, de familiares e dos demais colegas de trabalho no sentido de desempenharem um cuidado de qualidade, atentos às necessidades daqueles que estão ali para serem cuidados. Em meio a todo investimento para cuidar do outro, parece estar faltando espaço para cuidar de si e para encontrar suporte junto aos demais profissionais, colegas de trabalho. Dessa forma, senti que a entrevista foi também uma oportunidade de eles olharem para a trajetória que têm percorrido e para a história que estão construindo, refletirem sobre sua atuação, aproximarem-se de suas vivências e de me deixarem chegar mais perto, de se verem e se deixarem serem vistos, de cuidarem de si mesmos e de se permitirem serem cuidados, de se ouvirem e de serem ouvidos, de reavaliarem, construírem possibilidades, ressignificarem e elaborarem suas vivências...

Acredito que conhecendo a realidade desses profissionais, é possível ressaltar, mais uma vez, a necessidade de olhar para a qualidade de vida e a saúde mental dessas pessoas que desempenham um cuidado ao outro, mas que carecem de cuidado para si.

Será que eles estão emocionalmente “alimentados” para fornecerem “alimento”?

Casate e Corrêa (2005, p. 110) questionam:

estarão os trabalhadores da saúde em condições de garantir um atendimento humanizado, tendo em vista que, quase sempre, são submetidos a processos de trabalhos mecanizados que os limitam na possibilidade de se transformarem em pessoas mais críticas e sensíveis, bem como se encontram fragilizados no conviver contínuo com a dor, o sofrimento, a morte e a miséria?

Andreis, Chitero e Silva (2008) alertam que as iniciativas de gerenciamento de estresse nas organizações, quando existentes, em geral, restringem-se a medidas para proporcionar alívio da tensão através de atividades pontuais associadas à qualidade de vida. Apesar de auxiliarem no alcance do bem-estar pessoal através da melhora dos sintomas de estresse, é preciso ir além, buscando compreender as causas do estresse, facilitando a comunicação em grupo e gerenciando dificuldades como forma de alcançar um ambiente de 
trabalho mais saudável, que seja bom tanto para os trabalhadores como para a instituição. Logo, apesar do reconhecimento sobre estressores ocupacionais associados ao trabalho do profissional de saúde, ainda há poucas medidas profiláticas e terapêuticas colocadas em prática no contexto hospitalar. As autoras acreditam que reconhecer a importância de medidas de gerenciamento de estresse é o primeiro passo na busca de desenvolvimento de medidas preventivas e terapêuticas.

Por isso, é essencial que exista uma mudança do ponto de vista institucional em relação aos seus funcionários, já que a qualidade da assistência está estritamente ligada à saúde mental e ao bem-estar dos profissionais responsáveis pelo cuidado aos doentes.

Como forma de auxiliar esses profissionais de saúde na adaptação ao seu contexto de trabalho e no enfrentamento de situações, alguns trabalhos propõem a oferta de assistência psicológica aos profissionais de saúde através de atendimentos grupais.

Nucci e Perina (2008) sugerem que grupos de reflexão destinados para cuidadores podem ser interessantes para que os mesmos possam identificar sentimentos e significados mobilizados neles mesmos.

Vinogradov e Yalom (1992) citam onze fatores terapêuticos que operam na psicoterapia de grupo: instilação de esperança, universalidade, oferecimento de informações, altruísmo, desenvolvimento de técnicas de socialização, comportamento imitativo, catarse, reedição corretiva do grupo familiar primário, fatores existenciais, coesão do grupo e aprendizagem interpessoal.

Sobre a universalidade, Chiattone (1998) ressalta que procedimentos realizados em grupo oferecem a vantagem de os integrantes sentirem que não estão sozinhos. É também uma oportunidade de vivenciarem situações semelhantes àquelas experimentadas no cotidiano e, entrando em contato com situações-problema dentro do grupo, os integrantes podem visualizar saídas e criar soluções adaptativas.

A respeito do altruísmo, Vinogradov e Yalom (1992) mencionam que, nos grupos de terapia, os pacientes são úteis uns aos outros, pois compartilham problemas, oferecem apoio, sugestões e insights. Com relação à catarse, os autores acreditam que o ato de ventilação das emoções provoca, por si só, um alívio emocional, sem causar, porém, uma mudança duradoura para o paciente. Apesar disso, ressaltam a importância de poder compartilhar e de ser aceito pelos demais integrantes do grupo.

É importante mencionar que a situação grupal é um espaço protegido em que os membros são acompanhados por um coordenador ou facilitador, logo, abre espaço para que assuntos que não são trocados no corredor de um hospital sejam trazidos à tona pelos 
participantes. É uma oportunidade para falar do ser-com que, neste contexto, é permeado por sofrimento, angústia, ansiedade, expectativa, medo e frustrações.

Nucci e Perina (2008) ressaltam a importância de se identificar sentimentos de tristeza, raiva, desânimo, desalento e alegria manifestados pelos profissionais de saúde, já que podem interferir no humor desses profissionais e, consequentemente, podem atrapalhar a comunicação entre os membros da equipe e entre esses e pacientes e seus familiares.

Para Campos (1992), as reuniões regulares de equipe de trabalho também podem ser um meio eficaz de compreender a dinâmica da equipe, para se trabalhar as dificuldades associadas ao trabalho multidisciplinar e à atuação junto aos pacientes.

Segundo Amorim, Lopes e Bruscato (2004), destinar atenção aos profissionais de saúde é uma ação psicológica profilática em saúde mental, que pode repercutir no aprimoramento desses profissionais para o desempenho de suas atividades e, consequentemente, em uma melhor assistência à clientela atendida.

De acordo com Amorim, Lopes e Bruscato (2004), formular programas de atuação junto a membros dessas equipes é uma oportunidade para prevenir e modificar padrões disfuncionais da relação desses profissionais com seu trabalho cotidiano.

Assim como alguns participantes deste estudo pontuaram, a consolidação de grupos de assistência psicológica aos profissionais de saúde requer uma organização da rotina do serviço de forma a encaixar esse processo de cuidado - que não se destina a pacientes e familiares, mas que é essencial para a qualidade do serviço prestado - na rotina da instituição. Além disso, é necessária também a contratação de profissionais externos para a coordenação deste projeto.

Penso que os atendimentos em grupo são interessantes por proporcionarem um maior conhecimento e um estreitamento do vínculo entre os profissionais que atuam juntos, bem como por permitir acessar, de forma focal, as demandas vinculadas àquele contexto de trabalho específico. Porém, acredito ser necessário oferecer a esses profissionais de saúde outros meios de atendimento psicológico, como a assistência individual, já que alguns indivíduos apresentam resistência ao atendimento em grupo. Pelo fato de parecer inviável que a instituição disponibilize atendimento individual a todos seus funcionários, uma possibilidade seria a criação de estágios curriculares junto às faculdades de Psicologia de Ribeirão Preto. Outra possibilidade seria firmar convênios junto a psicólogos da cidade, como forma de disponibilizar atendimentos psicológicos a um preço acessível a esses profissionais.

Campos (1992) defende que características pessoais de membros de uma equipe podem favorecer ou dificultar o processo de trabalho, na medida em que haja maior ou menor 
disponibilidade para analisar situações conflituosas. Por isso, a autora acredita que o autoconhecimento proporcionado por uma psicoterapia pessoal poderá ajudar os profissionais a tomarem consciência de suas possibilidades e dificuldades de integração. Enfatiza também a importância de reuniões regulares da equipe de trabalho e de supervisões dessa mesma equipe, de preferência por profissionais não vinculados à instituição, como formas de favorecer a compreensão da dinâmica da equipe.

Acredito que também seja importante realizar palestras com o intuito de orientar e informar os profissionais da saúde, sobre os riscos aos quais estão expostos pelo trabalho que executam, como forma de ajudá-los a reconhecer suas necessidades e dificuldades, bem como de alertá-los sobre a importância de se cuidar da própria saúde física e mental.

Segundo Gomes, Lunardi Filho e Erdmann (2006), o fato de alguns profissionais negarem ou desconhecerem os riscos de adoecimento psíquico presentes em seu trabalho impedem que mudanças sejam promovidas para alterar essa realidade, já que eles deveriam ser os principais ativistas dessas transformações.

Por fim, como foi discutido anteriormente, é necessário repensar a formação desses profissionais de saúde, bem como investir na qualificação dos profissionais envolvidos na assistência, como forma de dar continuidade a essa formação através de treinamentos e cursos, mesmo após a inserção no mercado de trabalho.

Casate e Corrêa (2005, p. 110) orientam:

Ter sensibilidade para a escuta e o diálogo, mantendo relações éticas e solidárias, envolve um aprendizado contínuo e vivencial, pouco enfatizado no ambiente de trabalho, levando-se em conta, ainda, o predomínio de estruturas administrativas tradicionais, rígidas e burocratizadas.

Sposati et al $^{21}$ (1992 apud ANDREIS, CHITERO e SILVA, 2008) alertam, também, sobre a importância de se desenvolver atividades visando a que os alunos possam refletir a respeito do trabalho por eles realizado, bem como sobre sua significação, seus anseios e seus limites, como forma de prevenir uma dessubjetivação progressiva desses estudantes que arrastam consigo seus pacientes, os quais também se despersonalizam.

\footnotetext{
${ }^{21}$ SPOSATI, M. et al. Relato de experiência da participação do psicólogo hospitalar em disciplina do Curso de Medicina da Santa Casa de São Paulo. Tema Livre apresentado no I Congresso Brasileiro de Psicologia Hospitalar. São Paulo, 1992.
} 


\section{PalaVRas Finais}

Ao reler este estudo, revivo e atualizo algumas experiências que ocorreram no decorrer de seu desenvolvimento.

Assim como Forghieri (2009) pontua no início de seu livro, também me vi lidando com experiências paradoxais em relação a este trabalho, ora me sentindo satisfeita, segura e tranquila, mas, em outras circunstâncias, senti-me tomada pela angústia, que me mobilizou em vários momentos a fazer alterações e reconstruções.

Apesar dessas experiências paradoxais, hoje, caminhando para o término da redação deste estudo, percebo que, unindo a leitura de publicações, o contato com os participantes deste estudo, a análise dos discursos dos mesmos, bem como me abrindo às minhas próprias inquietações e reflexões, foi possível cumprir os objetivos deste trabalho.

Pude acessar os significados que os entrevistados atribuem ao cuidado a crianças e adolescentes com câncer, as dificuldades e as satisfações experimentadas, bem como os recursos de enfrentamento utilizados por esses profissionais. Pude compreender melhor de que maneira as relações humanas se dão nesta instituição, como os profissionais se relacionam entre si e com seus pacientes, bem como os significados que atribuem a essas vivências.

Espero que esse estudo, por ter podido alargar a compreensão referente às necessidades dos profissionais de saúde, desvelando parte dessa realidade, possa proporcionar questionamentos, incômodos e, consequentemente, transformações. Do meu ponto de vista, este estudo escancara a existência de uma "pedra no sapato" que, ao mesmo tempo em que traz desconforto e dificulta o caminhar, pode impulsionar mudanças rumo a uma situação mais favorável, destinando atenção à saúde mental dos trabalhadores.

Vale relembrar que, segundo o caminho metodológico escolhido, esse estudo buscou descortinar aspectos de uma realidade específica, não devendo ser tomado como uma verdade absoluta.

Ao dirigir o olhar para mim mesma, em um movimento reflexivo, percebo as mudanças que ocorreram no meu modo de ser-no-mundo ao longo desses dois anos de desenvolvimento deste estudo. Para mim, hoje, é interessante perceber meu próprio movimento... Como eu era antes e após o desenvolvimento deste trabalho; como visualizava esse fenômeno "ser-profissional-atuante-em-Oncologia-pediátrica” antes e agora... Muitas coisas foram transformadas na minha vida pessoal e profissional, contribuindo para novas 
percepções e compreensões, bem como algumas mudanças e substituições que retratam a minha própria condição de vir-a-ser.

Os colaboradores deste estudo, como o próprio nome diz, colaboraram para meu desenvolvimento pessoal e profissional. Como Capalbo (1980, p. 65) ressalta, "no encontro sempre se dá e se recebe. Trata-se do encontro sob a forma da coexistência - do existir com”.

O contato com os profissionais de saúde foi um momento especial no desenvolvimento deste trabalho. Antes de iniciar os convites aos possíveis participantes, acreditava que poderia enfrentar muitas recusas dos profissionais por desinteresse ou falta de tempo. Porém, de forma surpreendente, a cada convite, uma aceitação, todas elas marcadas por total disponibilidade, refletida no desejo dos participantes de contribuírem ali mesmo, naquele dia ou marcando a entrevista para a mesma semana. Sinto-me à vontade para relatar meu contato com o médico participante deste estudo que, após aceitar o convite, conseguiu se organizar para me atender na semana seguinte, no início da manhã, às seis horas em seu consultório, ficando por quase uma hora dividindo suas experiências comigo. Diante de todos os movimentos em prol de contribuir com este trabalho, fui tomada por sentimentos de gratidão e admiração. Esses sentimentos exacerbaram-se ao perceber a confiança com que aceitaram dividir suas histórias pessoais e profissionais. Pude experimentar histórias intensas, com diferentes cores e sabores, ora marcadas por satisfações em relação à atuação em Oncologia Pediátrica, ora por dificuldades, mas a grande maioria dos discursos fala de dedicação, persistência, esperança, amor à profissão e à função desempenhada.

Hoje, penso que esse estudo foi um presente a mim concedido que, muito além do título de mestre e do aprendizado em termos de desenvolvimento de pesquisa, me enriqueceu enquanto pessoa e psicóloga, ampliando a compreensão de mim mesma e do mundo.

O que antes me intrigava passou a ser a questão norteadora do meu trabalho, que me ofereceu algumas respostas para minhas perguntas. Porém, segundo o próprio olhar fenomenológico que retrata a inesgotabilidade do fenômeno, percebo que o caminho trilhado ao responder algumas inquietações, abriu margem para novos questionamentos. E, com certeza, outros surgirão no contato com outras pessoas que lerão meu trabalho e essas mesmas farão seus questionamentos singulares.

As respostas encontradas e as perguntas suscitadas revelam a relevância de investigações futuras, já que não é possível esgotar de forma absoluta um fenômeno em estudo, uma vez que o homem se projeta no mundo sempre de forma inédita. 
O trabalho permitiu, sim, acomodar algumas inquietações, mas suscitou novas perguntas... novos desejos, que ainda estão sendo elaborados aqui comigo! Mas como ressalta Alves (2004, p. 22),

Conclusões são chaves que fecham. Cada conclusão faz parar o pensamento. Palavras não conclusivas deixam abertas as portas das gaiolas para que os pássaros voem de novo. Cada palavra deve ter reticências para o pensamento continuar seu voo. 


\section{REFERÊNCIAS}

ALBUQUERQUE, C. M. S.; OLIVEIRA, C. P. F. Saúde e doença: significações e perspectivas em mudança. Millennium - Revista do Instituto Politécnico de Viseu (ISPV), Viseu, n. 25, jan. 2002. Disponível em: <http://hdl.handle.net/10400.19/635>. Acesso em: 17 set. 2009.

ALBUQUERQUE, F. J. B.; PUENTE-PALACIOS, K. E. Grupos e equipes de trabalho nas organizações. In: ZANELLI, J. C.; BORGES-ANDRADE, J. E.; BASTOS, A. V. B. (Org.). Psicologia, organizações e trabalho no Brasil. Porto Alegre: Artmed, 2004. p. 357-379.

ALMEIDA, E. C. O psicólogo no hospital geral. Psicologia, Ciência e Profissão, Brasília, v. 20, n. 3, p. 24-27, set. 2000.

ALMEIDA FILHO, N. Transdisciplinaridade e o paradigma pós-disciplinar na saúde. Saúde e Sociedade, São Paulo, v. 14, n. 3, p. 30-50, dez. 2005.

ALVES, V. L. P. Psicoterapia conjugal: pesquisa fenomenológica. In: BRUNS, M. A. T.; HOLANDA, A. F. (Org.). Psicologia e fenomenologia: reflexões e perspectivas. Campinas: Alínea, 2003. p. 93-117.

ALVES, R. Presente: frases, ideias e sensações... Campinas: Papirus, 2004. 96 p.

AMARAL, M. T. C. A arte significando vivências de médicos que cuidam de crianças com câncer. 2002. 111 f. Dissertação (Mestrado em Psicologia) - Faculdade de Filosofia, Ciências e Letras de Ribeirão Preto, Universidade de São Paulo, Ribeirão Preto, 2002.

AMATUZZI, M. M. Pesquisa fenomenológica em psicologia. In: BRUNS, M. A. T.; HOLANDA, A. F. (Org.). Psicologia e fenomenologia: reflexões e perspectivas. Campinas: Alínea, 2003. p. 17-26.

AMORIM, S. F.; LOPES, S. R. A.; BRUSCATO, W. L. Intervenção psicológica na equipe de saúde. In: BRUSCATO, W. L.; BENEDETTI, C.; LOPES, S. R. A. (Org.). A prática da psicologia hospitalar na Santa Casa de São Paulo: novas páginas de uma antiga história. São Paulo: Casa do Psicólogo, 2004. p. 195-201.

ANDRÉA, M. L. M. Oncologia pediátrica. In: CARVALHO, V. A. et al. Temas em PsicoOncologia. São Paulo: Summus, 2008. p. 478-495. 
ANDREIS, M.; CHITERO, E. F.; SILVA, S. C. A. Situações psicologicamente difíceis: preparo das equipes. In: KNOBEL, E.; ANDREOLI, P. B. A. A; ERLICHMAN, M. R. Psicologia e humanização: assistência aos pacientes graves. São Paulo: Atheneu, 2008. p. 311-323.

ANDREOLI, P. B. A. et al. Aspectos psicológicos do paciente grave. In: KNOBEL, E. Condutas no paciente grave. 3. ed. São Paulo: Atheneu, 2006. p. 2009-2021.

ANGERAMI-CAMON, V. A. Psicologia da saúde: um novo significado para clínica. São Paulo: Pioneira, 2000. 226p.

ARANHA, M. L. A.; MARTINS, M. H. P. M. Filosofando: introdução à filosofia. 2. ed. São Paulo: Moderna, 1993. 395p.

ARECO, N. M. Cuidados paliativos: a vivência de profissionais de uma equipe interdisciplinar na assistência a crianças e adolescentes com câncer. 2011. 140 f. Dissertação (Mestrado em Psicologia) - Faculdade de Filosofia, Ciências e Letras de Ribeirão Preto, Universidade de São Paulo, Ribeirão Preto, 2011.

AZZI, S. G. F.; ANDREOLI, P. B. A. O cuidado da criança hospitalizada com doença grave e sua família. In: KNOBEL, E.; ANDREOLI, P. B. A. A.; ERLICHMAN, M. R. Psicologia e Humanização: assistência aos pacientes graves. São Paulo: Atheneu, 2008. p. 93-100.

BIANCHI, E. R. F. Stress entre enfermeiros hospitalares. 1999. 101 f. Tese (LivreDocência em Enfermagem) - Escola de Enfermagem, Universidade de São Paulo, São Paulo, 1999.

BICUDO, M. A. V. Sobre a fenomenologia. In: BICUDO, M. A. V.; ESPOSITO, V. H. C. (Org.). Pesquisa qualitativa em educação: um enfoque fenomenológico. Piracicaba: UNIMEP, 1994. p. 15-22.

BONAMIN, L. V. O estresse e as doenças. Ciência Hoje, Rio de Janeiro, v. 17, n. 99, p. 2530, 1985.

BRANDÃO, C. L. C. et al. A imagem corporal do idoso com câncer atendido no ambulatório de cuidados paliativos do ICHC- FMUSP. Psicologia Hospitalar, São Paulo, v. 2, n. 2, dez. 2004. Disponível em: <http://pepsic.bvsalud.org/scielo.php?script=sci_arttext\&pid=S1677 74092004000200007\&lng=pt\&nrm=iso>. Acesso em: 03 jan. 2012.

BRASIL. Ministério da Saúde. Conselho Nacional de Saúde. Resolução n 196/96 sobre pesquisa envolvendo seres humanos. Brasília, DF, 1996. 
BRASIL. Ministério da Saúde. Instituto Nacional de Câncer (INCA). Coordenação Nacional de Controle de Tabagismo - CONTAPP. Falando sobre câncer e seus fatores de risco. Rio de Janeiro: INCA, 1997. 82p.

Ministério da Saúde. Instituto Nacional de Câncer (INCA). Estimativa 2010: incidência de câncer no Brasil. Rio de Janeiro: INCA, 2009. 98p.

. Ministério da Saúde. Instituto Nacional de Câncer (INCA) José Alencar Gomes da Silva. Coordenação Geral de Ações Estratégicas. Coordenação de Prevenção e Vigilância. Estimativa 2012: incidência de câncer no Brasil. Rio de Janeiro: INCA, 2011. 118p.

- Ministério da Saúde. Instituto Nacional de Câncer (INCA). Particularidades do câncer infantil. Disponível em: <http://www.inca.gov.br/conteudo_view.asp?id=343>. Acesso em: 08 maio 2012.

BRUNS, M. A. T. A redução fenomenológica em Husserl e a possibilidade de superar a dicotomia subjetividade-objetividade. In: BRUNS, M. A. T.; HOLANDA, A. F. (Org.). Psicologia e fenomenologia: reflexões e perspectivas. Campinas: Alínea, 2003. p. 65-75.

BRUNS, M. A. T.; TRINDADE, E. Metodologia fenomenológica: a contribuição da ontologia-hermenêutica de Martin Heidegger. In: BRUNS, M. A. T.; HOLANDA, A. F. Psicologia e fenomenologia: reflexões e perspectivas. Campinas: Alínea, 2003. p. 77-91.

BRUSCATO, W. L. et al. O trabalho em equipe multiprofissional na saúde. In: BRUSCATO, W. L.; BENEDETTI, C.; LOPES, S. R. A. (Org.). A prática da psicologia hospitalar na Santa Casa de São Paulo: novas páginas de uma antiga história. São Paulo: Casa do Psicólogo, 2004. p. 34-41.

CAMARGO, B.; LOPES, L. F. Pediatria oncológica: noções fundamentais para o pediatra. São Paulo: Lemar, 2000. 344p.

CAMPOS, M. A. O trabalho em equipe multiprofissional: uma reflexão crítica. Jornal Brasileiro de Psiquiatria, Rio de Janeiro, v. 41, n. 6, p. 255-257, 1992.

CAPALBO, C. Algumas considerações sobre a fenomenologia que podem interessar ao serviço social. Suplemento de Debates Sociais, Rio de Janeiro, n. 8, p. 58-66, ago. 1980. 1987. p. 5-8.

Prefácio. In: CARVALHO, A. S. Metodologia da entrevista. Rio de Janeiro: Agir, - Considerações sobre o método fenomenológico e a enfermagem. Revista de Enfermagem UERJ, Rio de Janeiro, v. 2, n. 2, p. 192-197, 1994. 
CAPARELLI, A. B. F. As vivências do médico diante do diagnóstico do câncer infantil. 2002. 144 f. Dissertação (Mestrado em Psicologia) - Faculdade de Filosofia Ciências e Letras de Ribeirão Preto, Universidade de São Paulo, Ribeirão Preto, 2002.

CAPRA, F. O ponto de mutação. 17. ed. São Paulo: Cultrix, 1996. 445p.

CARTER, B.; MCGOLDRICK, M. As mudanças no ciclo de vida familiar: uma estrutura para terapia familiar. 2. ed. Porto Alegre: Artes Médicas, 1995. 512p.

CARVALHO, A. S. Metodologia da entrevista. 2. ed. Rio de Janeiro: Agir, 1987. 93p.

CASATE, J. C.; CORRÊA, A. K. Humanização do atendimento em saúde: conhecimento veiculado na literatura brasileira de enfermagem. Revista Latino-Americana de Enfermagem, Ribeirão Preto, v. 13, n. 1, p. 105-111, jan./fev. 2005.

CHIATTONE, H. B. C.; SEBASTIANI, R. W. A Ética em psicologia hospitalar. In: ANGERAMI-CAMON, V. A. (Org.). A ética na saúde. São Paulo: Pioneira, 1997. p. 113139.

CHIATTONE, H. B. C. Urgências psicológicas em leucemias. In: ANGERAMI-CAMON, V. A. (Org.). Urgências psicológicas no hospital. São Paulo: Pioneira, 1998. p. 171-191.

CHIATTONE, H. B. C. A criança e a morte. In: ANGERAMI-CAMON, V.A. (Org.). E a psicologia entrou no hospital... São Paulo: Pioneira, 2001. p. 69-141.

COLLANTES, D. S. Contribuições da medicina da família para a família do século XXI. Revista Portuguesa de Clínica Geral, Lisboa, v. 17, p. 337-338, 2001.

CRITELLI, D. M. Analítica do sentido: uma aproximação e interpretação do real de orientação fenomenológica. São Paulo: EDUC/Editora Brasiliense, 2007. 140p.

DARTIGUES, A. O que é fenomenologia? Tradução Maria José J. G. de Almeida. 3. ed. São Paulo: Moraes, 1992. 174p.

DEITOS, T. F. H.; GASPARY, J. F. P. Efeitos biopsicossociais e psiconeuroimunológicos do câncer sobre o paciente e familiares. Revista Brasileira de Cancerologia, Rio de Janeiro, v. 43, n. 2, p. 117-126, abr./jun. 1997.

DEJOURS, C. A loucura do trabalho: estudo de psicopatologia do trabalho. 2. ed. São Paulo: Cortez/Oboré, 1987. 182p. 
DEJOURS, C. Introdução à psicopatologia do trabalho. In: HIRATA, H. (Org.). Divisão capitalista do trabalho. Tempo Social: Revista de Sociologia da USP, São Paulo, v. 1, n. 2, p. 73-103, jan./jun. 1989.

DORÓ, M. P.; PASQUINI, R. Transplante de medula óssea: uma confluência biopsicossocial. InterAÇÃO, Curitiba, v. 4, p. 39-60, 2000.

ESPERIDIÃO, E.; MUNARI, D. B. Holismo só na teoria: a trama dos sentimentos do acadêmico de enfermagem sobre sua formação. Revista da Escola de Enfermagem da USP, São Paulo v. 38, n. 3, p. 332-340, set. 2004.

FEIJOO, A. M. L. C. A psicoterapia em uma perspectiva fenomenológico-existencial. In: ANGERAMI-CAMON, V. A. (Org.). Psicoterapia fenomenológico-existencial. São Paulo: Pioneira Thomson Learning, 2002. p. 131-157.

FERREIRA, N. M. L. A. A difícil convivência com o câncer: um estudo das emoções na enfermagem oncológica. Revista da Escola de Enfermagem da USP, São Paulo, v. 30, n. 2, p. 229-253, 1996.

FERREIRA, L.C.R. Reflexões acerca das contribuições de Heidegger para uma clínica fenomenológica-existencial. 2010. 100 f. Dissertação (Mestrado em Psicologia) - Instituto de Ciências Humanas e Filosofia, Universidade Federal Fluminense, Niterói, 2010.

FINI, M. I. Sobre a pesquisa qualitativa em educação, que tem a Fenomenologia como Suporte. In: BICUDO, M. A.; ESPOSITO, V. H. (Org.). Pesquisa qualitativa em educação. Piracicaba: Unimep, 1994. cap. 3, p. 23-33.

FIORINI, H. J. Teorias e técnicas psicoterápicas. Rio de Janeiro: Francisco Alves, 1989.

FONTES, A. P.; NERI, A. L.; YASSUDA, M. S. Enfrentamento do estresse no trabalho: relações entre idade, experiência, autoeficácia e agência. Psicologia, Ciência \& Profissão, Brasília, v. 30, n. 3, p. 620-633, set. 2010.

FORGHIERI, Y. C. Fenomenologia, existência e psicoterapia. In: (Org.). Fenomenologia e psicologia. São Paulo: Cortez, 1984. p. 11-34. 2009. 81p.

Psicologia fenomenológica: fundamentos, método e pesquisa. São Paulo: Pioneira,

FRANÇOSO, L. P. C.; VALLE, E. R. M. Grupo de apoio psicológico: possibilidade de intervenção psicoterapêutica junto à criança com câncer. Pediatria Atual, São Paulo, v. 13, n. 3, p. 32-37, 2000. 
FRANÇOSO, L. P. C. Assistência Psicológica à criança com câncer. In: VALLE, E.R.M. (Org.) Psico-oncologia pediátrica. São Paulo: Casa do Psicólogo, 2001. p. 75-128.

GALVÁN, G. B. Equipes de saúde: o desafio da integração disciplinar. Revista SBPH, Rio de Janeiro, v. 10, n. 2, p. 53-61, 2007.

GARNICA, A. V. M. Algumas notas sobre pesquisa qualitativa e fenomenologia. Interface Comunicação, Saúde, Educação, Botucatu, v. 1, n. 1, p. 109-122, 1997.

GAUDERER, E. C. Reação do profissional frente à doença crônica ou fatal. Jornal Brasileiro de Medicina, Rio de Janeiro, v. 40, n. 3, p. 47-56, 1981.

GIORGI, A. Psicologia como ciência humana: uma abordagem de base fenomenológica. Tradução Riva S. Schwartzman. Belo Horizonte: Interlivros, 1978. 230p.

GIORGI, A. Phenomenology and psychological research. Pittsburgh: Duchesne University Press, 1985. 216p.

GOMES, G. C. LUNARDI FILHO, W. D.; ERDMANN, A. L. O sofrimento psíquico em trabalhadores de UTI interferindo no seu modo de viver a enfermagem. Revista de Enfermagem UFRJ, Rio de Janeiro, v. 14, n. 1, p. 93-99, 2006.

GUYATT, G. H.; FEENY, D. H.; PATRICK, D. L. Measuring health-related quality of life. Annals of Internal Medicine, Hamilton, v. 118, n. 8, p. 622-629, 1993.

HOLANDA, A. Pesquisa fenomenológica e psicologia eidética: elementos para um entendimento metodológico. In: BRUNS, M. A. T.; HOLANDA, A. F. (Org.). Psicologia e fenomenologia: reflexões e perspectivas. Campinas: Alínea, 2003. p. 41-63.

HOSPITAL DO CÂNCER. Crianças com câncer: o que devemos saber? Um guia para pais e familiares de crianças e adolescentes em tratamento. São Paulo: Comunique Editorial, 2003. 129p.

KIRSCHBAUM, D. I. R.; SILVA, J. B. O sofrimento psíquico dos enfermeiros que lidam com pacientes oncológicos. Revista Brasileira de Enfermagem, Brasília, v. 51, n. 2, p. 273290, 1998.

KITAJIMA, K.; COSMO, M. Comunicação entre paciente, família e equipe no CTI. In: KNOBEL, E.; ANDREOLI, P. B. A. A; ERLICHMAN, M. R. Psicologia e Humanização: assistência aos pacientes graves. São Paulo: Atheneu, 2008. p. 101-112. 
KOIFMAN, L. O modelo biomédico e a reformulação do currículo médico da Universidade Federal Fluminense. História, Ciências, Saúde - Manguinhos, Rio de Janeiro, v. 8, n. 1, p. 48-70, 2001.

LAUTERT, L.; CHAVES, E. H. B.; MOURA, G. M. S. S. O estresse na atividade gerencial do enfermeiro. Revista Panamericana de La Salud Pública, Washington, v. 6, n. 6, p. 415425, 1999.

LIMA, J. O. R. et al. Aprendendo o cuidado humanizado: a perspectiva do graduando de enfermagem. Ciência, Cuidado e Saúde, Maringá, v. 6, n.1, p. 11-20, 2007.

LIMA, M. G. S. Atendimento psicológico da criança no ambiente hospitalar. In: BRUSCATO, W. L.; BENEDETTI, C.; LOPES, S. R. A. (Org.). A prática da psicologia hospitalar na Santa Casa de São Paulo: novas páginas de uma antiga história. São Paulo: Casa do Psicólogo, 2004. p. 82-87.

LIPP, M. E. N. et al. Como enfrentar o stress infantil. São Paulo: Ícone, 1991. 96p.

LUYPEN, W. La fenomenologia es un humanismo. Buenos Aires: Ediciones Carlos Lohlé, 1967. 94p.

MACEDO, P. C. M.; NOGUEIRA-MARTINS, M. C. F.; NOGUEIRA-MARTINS, L. A. Técnicas de intervenção psicológica para humanização das equipes de saúde: grupos Balint e grupos de reflexão sobre a tarefa assistencial. In: KNOBEL, E.; ANDREOLI, P. B. A. A.; ERLICHMAN, M. R. Psicologia e humanização: assistência aos pacientes graves. São Paulo: Atheneu, 2008. p. 325-341.

MACIEL, J. C. Franz Clemens Brentano e a psicologia. In: BRUNS, M. A. T.; HOLANDA, A. F. (Org.). Psicologia e fenomenologia: reflexões e perspectivas. Campinas: Alínea, 2003. p. 27-39.

MACHADO, M. Equipes de trabalho: sua efetividade e seus preditores. 1998. Dissertação (Mestrado em Psicologia) - Instituto de Psicologia, Universidade de Brasília, Brasília, 1998.

MACHADO, M. H. Os médicos no Brasil: um retrato da realidade. Rio de Janeiro: Editora Fiocruz, 1997. 224p.

MACHADO, O. V. M. Pesquisa qualitativa: modalidade fenômeno situado. In: BICUDO, M. A. V.; ESPOSITO, V. H. C. (Org.). Pesquisa qualitativa em educação: um enfoque fenomenológico. Piracicaba: UNIMEP, 1994. p. 35-46. 
MARCO, M. A. (Org.). A face humana da medicina: do modelo biomédico ao modelo biopsicossocial. São Paulo: Casa do Psicólogo, 2003. 269p.

MARQUEZE, E.; CASTRO MORENO, C. Satisfação no trabalho - uma breve revisão. Revista Brasileira de Saúde Ocupacional, São Paulo, n. 30, p. 69-79, 2005.

MARTINS, J. Contribuição da fenomenologia à psicologia clínica: imaginação e fantasia. In: FORGHIERI, Y. C. (Org.). Fenomenologia e psicologia. São Paulo: Cortez/Editores Associados, 1984. p. 131-143.

MARTINS, J.; BICUDO, M. A. V. A pesquisa qualitativa em psicologia: fundamentos e recursos básicos. 5. ed. São Paulo: Centauro, 2005. 110p.

MARTINS, L. A. N. Atividade médica: fatores de risco para saúde mental do médico. Revista Brasileira de Clínica Terapêutica, São Paulo, v. 20, n. 9, p. 355-364, 1991.

MATTAR, C. M.; SÁ, R. N. de. Os sentidos de “análise” e "analítica” no pensamento de Heidegger e suas implicações para a psicoterapia. Revista Estudos e Pesquisa em Psicologia, Rio de Janeiro, ano 8, n.2, p. 191-203, 2008.

MEDEIROS, A. C. T.; ANDREOLI, P. B. A. Brinquedoteca e humanização da assistência à criança hospitalizada. In: KNOBEL, E.; ANDREOLI, P. B. A. A.; ERLICHMAN, M. R. Psicologia e humanização: assistência aos pacientes graves. São Paulo: Atheneu, 2008. p. 299-310.

MELEIRO, A. M. A. S. O médico como paciente. São Paulo: Lemos, 2001. 270p.

MELO, L. L.; VALLE, E. R. M. Equipe de enfermagem: experiências do cuidar da criança com câncer nos plantões noturnos. Revista Escola de Enfermagem da USP, São Paulo, v. 32, n. 4, p. 325-334, 1998.

MENZANI, G.; BIANCHI, E. R. F. Determinação dos estressores dos enfermeiros atuantes em unidade de internação. Enfermería Global, Espanha, n. 7, nov. 2005.

MINAYO, M. C. S. Interdisciplinaridade: uma questão que atravessa o saber, o poder e o mundo vivido. Medicina, Ribeirão Preto, v. 24, n. 2, p. 70-77, 1991.

MIRRA, A. P. Registros de câncer no Brasil e sua história. São Paulo: Tomgraf, 2005. 26p. 
MOREIRA, G. M. S.; VALLE, E. R. M. Estudos bibliográficos sobre publicações brasileiras relacionadas a aspectos psicossociais do câncer infantil, no período de 1980 a 1997. Revista Brasileira de Cancerologia, Rio de Janeiro, v. 45, n. 2, p. 27-35, 1999.

MOSCOVICI, F. Equipes que dão certo: a multiplicação do talento humano. 8. ed. Rio de Janeiro: José Olympio, 2003.

MOURA, C. A. R. Husserl, intencionalidade e fenomenologia. Revista Mente e Cérebro \& Filosofia, São Paulo, n. 5, p. 6-15, 2008.

MUCHAIL, S. T. Heidegger e os pré-socráticos. In: MARTINS, J.; DICHTCHEKENIAN, M. F. S. F. B. (Org.) Temas fundamentais de fenomenologia. São Paulo: Moraes, 1984. p. 916.

NOGUEIRA-MARTINS, L. A. A saúde do profissional da saúde. In: DE MARCO, M. A. (Org.). A face humana da medicina: do modelo biomédico ao modelo biopsicossocial. São Paulo: Casa do Psicólogo, 2003. p. 93-99.

NOGUEIRA-MARTINS, M. C. F. Cuidando do futuro cuidador. In: DE MARCO, M.A. (Org.). A Face humana da medicina: do modelo biomédico ao modelo biopsicossocial. São Paulo: Casa do Psicólogo, 2003. p. 87-92.

NUCCI, N. A. G.; PERINA, E. M. UTI de Oncologia pediátrica: reflexões sobre o cuidado humanizado. In: KNOBEL, E.; ANDREOLI, P. B. A. A.; ERLICHMAN, M. R. Psicologia e humanização: assistência aos pacientes graves. São Paulo: Atheneu, 2008. p. 281-290.

ORLEY, J.; KUYKEN, W. Quality of life assessment: international perspectives. Berlin: Springer-Verlag, 1994. 200p.

PARKER, G.N. Team players \& teamwork: a equipe e seus integrantes. São Paulo: Pioneira, 1994. 165p.

PEDUZZI, M. Equipe multiprofissional de saúde: conceito e tipologia. Revista de Saúde Pública, São Paulo, v. 35, n. 1, p. 103-109, 2001.

PENHA, J. O que é o existencialismo. São Paulo: Brasiliense, 2004. 124p.

PERESTRELLO, D. A medicina da pessoa. 4. ed. São Paulo: Ateneu, 1996. 272p. 
PINHO, L. B.; SANTOS, S. M. A. Dialética do cuidado humanizado na UTI: contradições entre o discurso e a prática profissional do enfermeiro. Revista da Escola de Enfermagem da USP, São Paulo, v. 42, n. 1, p. 66-72, 2008.

PITTA, A. Hospital: dor e morte como ofício. 4. ed. São Paulo: Hucitec, 1999. 199p.

QUINTANA, A. M.; CECIM, P. S; HENN, C. G. O preparo para lidar com a morte na formação do profissional de medicina. Revista Brasileira de Educação Médica, Rio de Janeiro, v. 26, n. 3, p. 204-210, 2002.

RABIN, S.; FELDMAN, D.; KAPLAN, Z. Stress and intervention strategies in mental health professionals. British Journal of Medical Psychology, London, v. 72, n. 2, p. 159-169, Jun. 1999.

REMEN, R. N. O paciente como ser humano. 3. ed. São Paulo: Summus, 1993. 224p.

ROBBINS, S. P. Administração: mudanças e perspectivas. São Paulo: Saraiva, 2008. 524p.

RODRIGUEZ-MARÍN, J. Psicología social de la salud. Madrid: Sínteses, 1995. 224p.

ROMANELLI, G. O processo saúde/doença em famílias de baixa renda e ação do Estado. Mimesis, Bauru, v. 24, n. 1, p. 109-123, 2003.

ROMANO, B. Princípios para a prática da psicologia clínica em hospitais. 4. ed. São Paulo: Casa do Psicólogo, 2007. 144p.

ROSA, C.; CARLOTTO, M. S. Síndrome de Burnout e a satisfação no trabalho em profissionais de uma instituição hospitalar. Revista SBPH, São Paulo, v. 8, n. 2, p. 1-15, 2005.

ROSSI, L. Vivências de mães de crianças com insuficiência renal crônica: um estudo fenomenológico. 2006. 164 f. Dissertação (Mestrado em Psicologia) - Faculdade de Filosofia, Ciências e Letras de Ribeirão Preto, Universidade de São Paulo, Ribeirão Preto, 2006.

RUDIO, F. V. Diálogo maiêutico e psicoterapia existencial. 2. ed. São José dos Campos: Novos Horizontes, 2001. 136p.

SANTOS, M. A. Perto da dor do outro, cortejando a própria insanidade: o profissional de saúde e a morte. Revista da SPAGESP, Ribeirão Preto, v. 4, n. 4, p. 43-51, 2003. 
SANVITO, W. L. A medicina tem cura? Uma abordagem crítica da medicina contemporânea. São Paulo: Atheneu, 1994. 116p.

SAPIENZA, B. T. Do desabrigo à confiança: Daseinsanalyse e terapia. São Paulo: Escuta, 2007. 132p.

SARTI, M. H. C. A criança hospitalizada: contribuição do desenho da figura humana para avaliação do seu estado emocional. 1988. 131 f. Dissertação (Mestrado em Psicologia) Instituto de Psicologia, Universidade de São Paulo, São Paulo, 1989.

SCHRAIBER, L. B. Desafios atuais da integridade em saúde. Jornal da Rede Feminista de Saúde, Porto Alegre, n. 17, p. 17-19, 1999.

SILVA, A. L. M.; ANDREOLI, P. B. A. Cuidando de pacientes "difíceis" ou famílias "difíceis”. In: KNOBEL, E.; ANDREOLI, P. B. A. A.; ERLICHMAN, M. R. Psicologia e humanização: assistência aos pacientes graves. São Paulo: Atheneu, 2008. p. 113-124.

SILVA, D. G. V. et al. Os desafios enfrentados pelos iniciantes na prática de enfermagem. Revista da Escola de Enfermagem da USP, São Paulo, v. 44, n. 2, p. 506-511, 2010.

SILVA, D. M. P. P.; MARZIALE, M. H. P. Absenteísmo de trabalhadores de enfermagem em um hospital universitário. Revista Latino-Americana de Enfermagem, Ribeirão Preto, v. 8, n. 5, p. 20-33, 2000.

SIMON, R. Psicologia clínica preventiva: novos fundamentos. São Paulo: EPU, 1989. 141p.

SOBRINHO, C. L. N. et al. Condições de trabalho e saúde mental dos médicos de Salvador, Bahia, Brasil. Cadernos de Saúde Pública, Rio de Janeiro, v. 22, n. 1, p. 131-140, 2006.

SOCIEDADE INTERNACIONAL DE ONCOLOGIA PEDIÁTRICA. Orientações psicossociais em oncologia pediátrica. Tradução Luciana Pagano Castilho Françoso e Elizabeth Ranier Martins do Valle. Ribeirão Preto: Grupo de Apoio à Criança com Câncer (GACC), 2000. 24p.

SOUZA, L. G. A.; BOEMER, M. R. O cuidar em situação de morte: algumas reflexões. Medicina, Ribeirão Preto, v. 38, n. 1, p. 49-54, 2005.

TILLICH, P. A coragem de ser. 2. ed. Rio de Janeiro: Paz e Terra, 1972. 146p.

TONETO, A. M.; GOMES, W. B. Prática psicológica em hospitais: demandas e intervenções. Revista PSICO, Porto Alegre, v. 36, n. 3, p. 283-291, 2005. 
TRINCA, A. M. T. A Apreensão de conteúdos emocionais de crianças em situação précirúrgica. 1987. 305 f. Dissertação (Mestrado em Psicologia) - Instituto de Psicologia, Universidade de São Paulo, São Paulo 1987.

TURATO, E. R. Métodos qualitativos e quantitativos na área da saúde: definições, diferenças e seus objetos de pesquisa. Revista de Saúde Pública, Campinas, v. 39, n. 3, p. 507-514, 2005.

VALENTINI, L. Fenomenologia e dialética. In: MARTINS, J.; DICHTCHEKENIAN, M. F. S. F. B. (Org.). Temas fundamentais em fenomenologia. São Paulo: Moraes, 1984. p. 3554.

VALLE, E. R. M. Câncer infantil - compreender e agir. Campinas: Psy, 1997. 205p.

(Org.). O cuidar de crianças com câncer: visão fenomenológica. Campinas: Livro Pleno, 2004. 240p.

VENDRUSCOLO, J. A criança curada de câncer ingressando no ambulatório de curados: um momento de passagem. 2006. 126 f. Tese (Doutorado em Psicologia) Faculdade de Filosofia, Ciências e Letras de Ribeirão Preto, Universidade de São Paulo, Ribeirão Preto, 2006.

VINOGRADOV, S.; YALOM, I. D. Como funciona a psicoterapia de grupo? In:

(Eds.). Manual de psicoterapia de grupo. Porto Alegre: Artes Médicas, 1992. cap. 2, p. 1638.

VON ZUBEN, N. A. Fenomenologia e existência: uma leitura de Merleau-Ponty. In: MARTINS, J.; DICHTCHEKENIAN, M. F. S. F. B. (Org.) Temas fundamentais de fenomenologia. São Paulo: Moraes, 1984. p. 55-68.

YAMAGUSHI, N. H. O câncer na visão da Oncologia. In: CARVALHO, M. M. I. J. Introdução à psico-oncologia. Campinas: Editorial Psy, 1994. p. 21-32. 
ANEXO

\section{ANEXO A - AUTORIZAÇÃO DO COMITÊ DE ÉTICA EM PESQUISA DO HCFMRP- USP PARA REALIZAÇÃO DO ESTUDO}

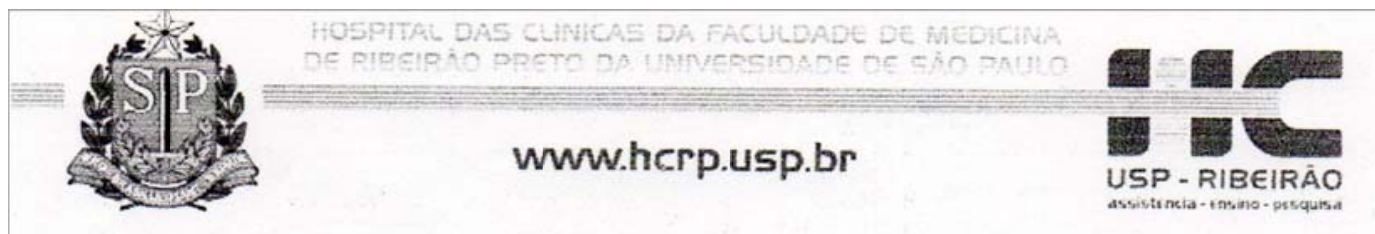

Ribeirão Preto, 28 de abril de 2010

Oficio $\mathrm{n}^{\circ} 1299 / 2010$

$\mathrm{CEP} / \mathrm{MGV}$

Prezadas Senhoras,

O trabalho intitulado "AS VIVÊNCIAS DE PROFISSIONAIS DE UMA EQUIPE DE SAÚdE NA ASSISTÊNCIA A CRIANÇAS E ADOLESCENTES COM CÂNCER" foi analisado pelo Comitê de Ética em Pesquisa, em sua $306^{a}$ Reunião Ordinária realizada em 26/04/2010 e enquadrado na categoria: APROVADO, bem como o Termo de Consentimento Livre e Esclarecido, de acordo com o Processo HCRP $n^{\circ} 3115 / 2010$.

Este Comitê segue integralmente a Conferência Internacional de Harmonização de Boas Práticas Clinicas (IGH-GCP), bem como a Resolução no 196/96 CNS/MS.

Lembramos que devem ser apresentados a este CEP, o Relatório Parcial e o Relatório Final da pesquisa.

Atenciosamente.

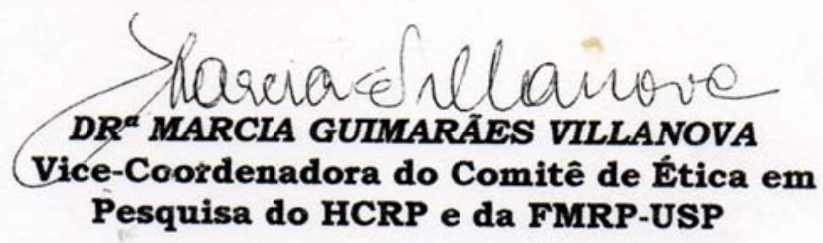

Ilustrissimas Senhoras

ROBERTA CANCELLA PINHEIRO ALVES

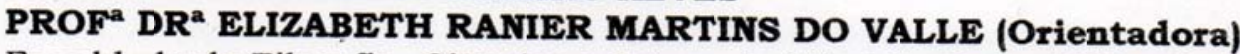

Faculdade de Filosofia, Ciências e Letras de Ribeirão Preto-USP - Depto. de

Psicologia e Educação 


\section{APÊNDICE}

\section{APÊNDICE A - TERMO DE CONSENTIMENTO LIVRE E INFORMADO \\ TERMO DE CONSENTIMENTO LIVRE E INFORMADO}

$\mathrm{Eu}$, informado sobre o projeto de pesquisa "As vivências de profissionais de uma equipe de saúde na assistência a crianças e adolescentes com câncer: um estudo fenomenológico.”, desenvolvido por Roberta Cancella Pinheiro Alves sob orientação da Prof ${ }^{a}$. Dra . Elizabeth Ranier Martins do Valle, junto ao Programa de Pós-Graduação em Psicologia do Departamento de Psicologia e Educação, da Faculdade de Filosofia, Ciências e Letras de Ribeirão Preto da Universidade de São Paulo.

Este estudo tem como objetivo compreender como o profissional de saúde que integra uma equipe interdisciplinar voltada para o cuidado a crianças e adolescentes com câncer, vivencia o cuidar dessa clientela.

Estou ciente de que a minha participação na pesquisa é voluntária, não podendo, portanto, ser imposta ou negociada. Fui informado de que nesta entrevista falarei principalmente sobre como eu vivencio a assistência a pacientes com câncer, e que o que eu disser será utilizado somente para finalidade de pesquisa, com a garantia de total anonimato quanto à minha identificação. Também fui informado de que as entrevistas serão gravadas e transcritas literalmente.

Tenho consciência de que posso interromper minha participação em qualquer fase da pesquisa, inclusive retirando a autorização para a utilização das informações que oferecerei. Sei também que não terei riscos, custos ou benefícios diretos.

Todas as minhas dúvidas com relação à pesquisa foram respondidas e o pesquisador colocou-se à disposição para esclarecer qualquer dúvida que eu possa vir a ter em qualquer momento da realização da pesquisa, ou mesmo após seu término. Sabendo disso e que o projeto foi submetido ao Comitê de Ética em Pesquisa do Hospital das Clínicas da Faculdade de Medicina de Ribeirão Preto - USP, concordo em participar.

de de 20

\section{Entrevistado}

Roberta Cancella Pinheiro Alves

Pesquisadora

Contato: (16) 9148-5747

Ribeirão Preto - SP
Elizabeth Ranier Martins do Valle

Orientadora

Contato: (16) 3911-1723

Ribeirão Preto - SP 